
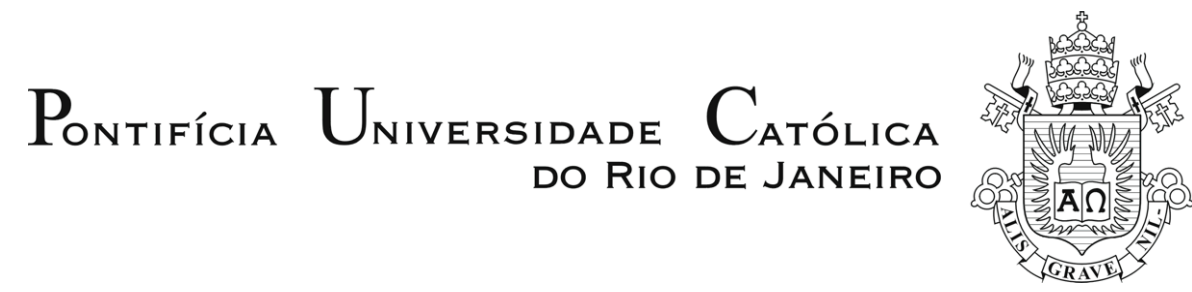

Vera Lopes de Abreu Lima

Comunicação na Utilização de Medicamentos por Pacientes Crônicos:

Uma abordagem ergonômica

Tese de Doutorado

Tese apresentada ao Programa de Pós-Graduação em Design do Departamento de Artes \& Design da PUC-Rio como requisito parcial para obtenção do título de Doutor em Design.

Orientadora: Profa. Anamaria de Moraes 


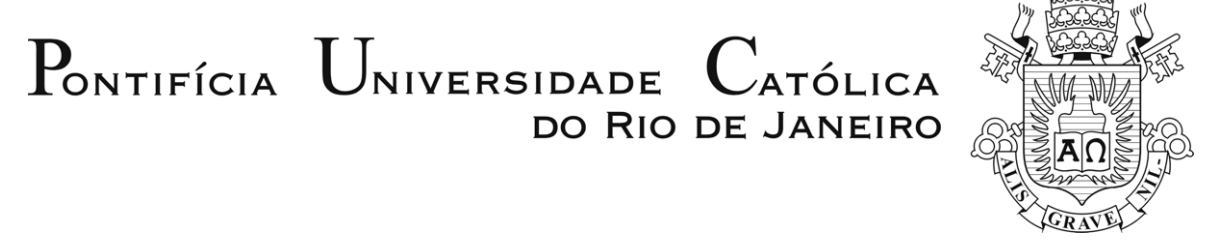

Vera Lopes de Abreu Lima

\section{Comunicação na Utilização de Medicamentos por Pacientes Crônicos: Uma abordagem ergonômica}

Tese apresentada ao Programa de Pós-Graduação em Design da PUC-Rio como requisito parcial para obtenção do título de Doutor em Design. Aprovada pela Comissão Examinadora abaixo assinada.

Profa. Anamaria de Moraes

Orientadora

Pontifícia Universidade Católica do Rio de Janeiro

Departamento de Artes \& Design

Profa. Claudia Garcia Serpa Osorio-de-Castro Fundação Oswaldo Cruz, Escola Nacional de Saúde Pública

Prof. Giuseppe Amado de Oliveira Universidade Federal Fluminense Centro Tecnológico, Escola de Engenharia

Profa. Claudia Renata Mont'Alvão

Pontifícia Universidade Católica do Rio de Janeiro Centro de Teologia e Ciências Humanas, Departamento de Design

Profa. Lúcia Gomes Ribeiro Pontifícia Universidade Católica do Rio de Janeiro Centro de Teologia e Ciências Humanas, Departamento de Design

Profa. Denise Berruezo Portinari Coordenadora Setorial do Centro de Teologia e Ciências Humanas PUC-Rio

Rio de Janeiro, 4 de abril de 2012 
Todos os direitos reservados. É proibida a reprodução total ou parcial do trabalho sem autorização do autor, do orientador e da universidade.

\section{Vera Lopes de Abreu Lima}

Graduou-se em Desenho Industrial pela Escola Superior de Desenho Industrial - ESDI, da Universidade do Estado do Rio de Janeiro em 2000. Mestre em Design pela Pontifícia Universidade Católica do Rio de Janeiro em 2007.

Ficha Catalográfica

Lima, Vera Lopes de Abreu
Comunicação na utilização de
medicamentos por pacientes crônicos: uma
abordagem ergonômica / Vera Lopes de Abreu
Lima ; orientadora: Anamaria de Moraes. - 2012.
198 f. ; 30 cm
Tese (doutorado)-Pontifícia Universidade
Católica do Rio de Janeiro, Departamento de Artes
e Design, 2012.
Inclui bibliografia
1. Artes e design - Teses. 2. Ergonomia
atenção à saúde. $3 . \quad$ Utilização de
medicamentos. 4 Comunicação em saúde. I.
Moraes, Anamaria de. II. Pontifícia Universidade
Católica do Rio de Janeiro. Departamento de Artes
\& Design. III. Título.

CDD: 700 
À professora Anamaria de Moraes. 


\section{Agradecimentos}

À professora Anamaria de Moraes, pela oportunidade.

Aos membros da banca, pela colaboração.

À Capes, pelo apoio financeiro.

Ao Dr. Raul Gonçalves Marques, pela colaboração na fase inicial desta pesquisa.

A Marion Villas Boas, pela inestimável ajuda.

Aos pacientes, que colaboraram e incentivaram a realização desta pesquisa respondendo aos questionários e entrevistas, alguns deles nos recebendo em suas casas.

À Cida, pela colaboração nas entrevistas.

A Débora, minha mãe, pela transcrição das entrevistas e todo a apoio.

A Flavinha, que me ajudou a retomar o fôlego e a tabular os dados.

Ao Fernando, meu amigo de mestrado e doutorado.

Ao Leandro Konder, querido professor.

Ao Miguel,

e à Isabel, por enfeitar o meu trabalho.

À PUC-Rio, com agradecimento especial ao Setor de Bibliotecas. 


\section{Resumo}

Lima, Vera Lopes de Abreu; Moraes, Anamaria. Comunicação na Utilização de Medicamentos por Pacientes Crônicos: Uma abordagem ergonômica. Rio de Janeiro, 2012, 198p. Tese de Doutorado Departamento de Artes e Design, Pontifícia Universidade Católica do Rio de Janeiro.

As doenças crônicas são as que mais afetam a população brasileira e, de maneira mais incisiva, parcelas da nossa população mais desfavorecidas socialmente. Com o envelhecimento da população há um consequente aumento de doentes crônicos que fazem uso diário de mais de um medicamento. A prescrição e dispensação adequadas e o uso racional dos medicamentos prescritos demanda que, tanto a tomada de informação pelo paciente/acompanhante ocorra de maneira eficaz, quanto que este consiga expressar-se com relação ao seu tratamento para os profissionais que o atendem. Ocorre que a comunicação presente no ciclo de utilização de medicamentos costuma apresentar falhas que comprometem a eficácia do tratamento medicamentoso. A Ergonomia, sendo uma tecnologia que trata da comunicação entre o homem e os outros elementos do sistema vem atuando no campo do atendimento em saúde. A presente pesquisa tem como hipótese que problemas na comunicação presente no ciclo de utilização de medicamentos no tratamento de enfermidades crônicas prejudicam a autoadministração consciente dos medicamentos por pacientes crônicos/seus acompanhantes. Para investigar esta hipótese foram utilizados os seguintes métodos e técnicas: pesquisa bibliográfica, entrevistas não-diretivas, questionários e entrevistas focadas com pacientes crônicos moradores na comunidade da Mangueira, na cidade do Rio de Janeiro. Os resultados apresentados corroboram pesquisas anteriores que apresentam problemas na comunicação relativa à utilização de medicamentos. E apresentas estratégias dos pacientes entrevistados para aprimorar seus tratamentos com medicamentos.

\section{Palavras-chave:}

Ergonomia na atenção em saúde, utilização de medicamentos, comunicação em saúde. 


\section{Abstract}

Lima, Vera Lopes de Abreu; Moraes, Anamaria (Advisor). Communication at Drug Utilization by Chronic Patients: An ergonomic approach. Rio de Janeiro, 2012, 198p. Doctorate Thesis - Departamento de Artes \& Design, Pontifícia Universidade Católica do Rio de Janeiro.

Chronic diseases represent a major health problem in Brazil. They affect the majority of the population and affect even more the poorest population within the country. As Brazilian population is becoming older, it also increases the number of people with chronic diseases, making daily use of multiple medications. For adequate prescription and dispensing, and wise use of medication effective communication is essential. Patient must get information about his treatment as well as to inform health professionals about his perceptions during medication utilization. Communication on drug utilization cycle may present flaws, impeding efficacy of drug treatment. Ergonomics, a technology that deals with communication between men and other parts of a defined system can collaborate with health care research. This investigation is based on the hypothesis that communication problems present ta drug utilization are obstacles to wise selfmanagement of chronic diseases drug treatment. To investigate this hypothesis, the four techniques used were: bibliographic review, opened interviews, and focused interviews with chronic patients living in Mangueira, a low-income area in Rio de Janeiro City. Results confirmed previous investigation showing deep problems related communication on drug utilization cycle. It also presented many methods patients develop to overcome difficulties and enhance their drugs treatment.

\section{Keywords:}

Ergonomics in healthcare. drug utilization, health communication. 


\section{Sumário}

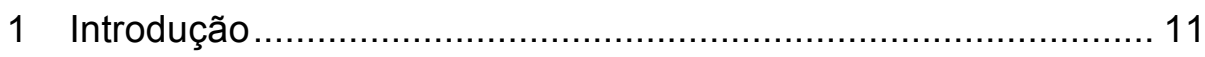

2 Doenças crônicas e atenção centrada no paciente ....................... 15

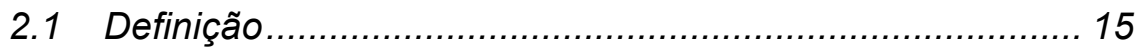

2.2 Doenças crônicas no Brasil ........................................... 16

2.3 Doenças crônicas e pobreza ............................................ 20

2.4 Modelo de atendimento em saúde para cuidado crônico... 22

2.5 O Modelo de Cuidado Crônico .......................................... 25

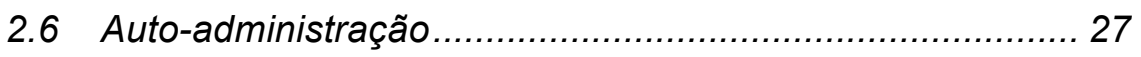

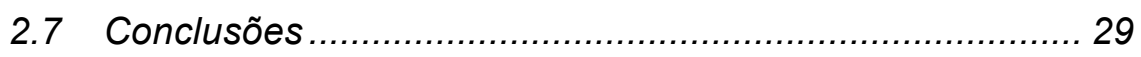

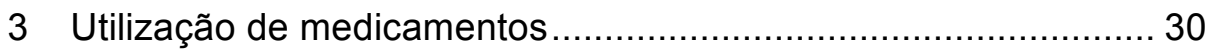

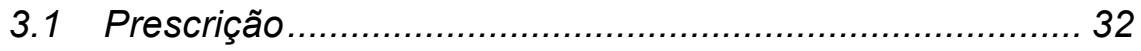

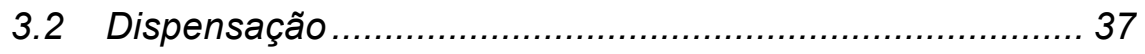

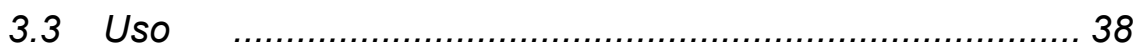

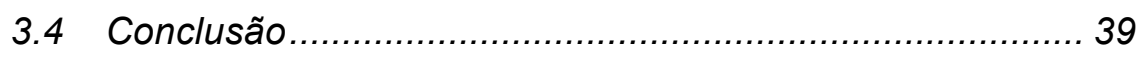

4 Ergonomia e assistência em saúde ......................................... 40

4.1 Ergonomia: áreas de especialização............................... 41

4.2 Ergonomia na assistência em saúde

e segurança do paciente ........................................................ 42

4.3 Conclusão.................................................................... 47

5 Modelagem da comunicação ...................................................... 48

5.1 Modelagem da comunicação.......................................... 49

5.1.1 O modelo de Shannon e Weaver .......................... 51

5.1.2 Schramm: destinatário e fonte devem estar sintonizados............................................. 54

5.1.3 Convergência da comunicação .............................. 58

5.1 .4 O modelo C-HIP ................................................. 61

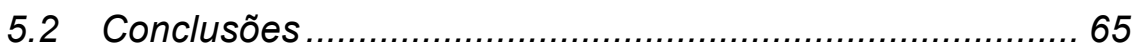

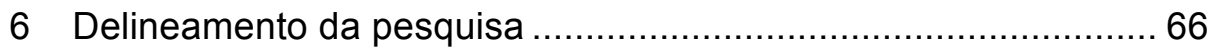

6.1 Tipo de pesquisa e fenômeno estudado........................... 66

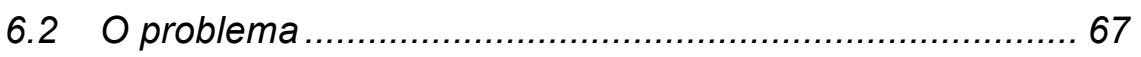




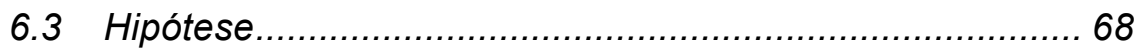

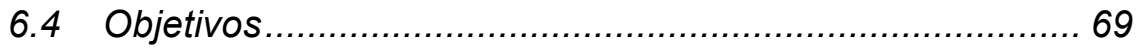

6.5 Sistematização da comunicação

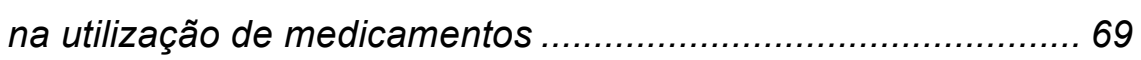

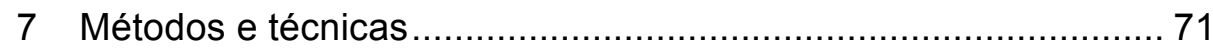

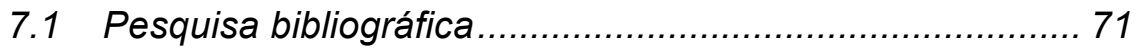

7.2 Ferramentas de pesquisa: primeira etapa ....................... 72

7.2.1 Entrevistas não-diretivas ................................... 72

7.2.2 A análise de conteúdo ................................... 73

7.2.3 Questionário ................................................... 76

7.3 Ferramentas da pesquisa: segunda etapa ...................... 83

7.3.1 Entrevistas focadas ...................................... 83

8 Resultados e discussão....................................................... 91

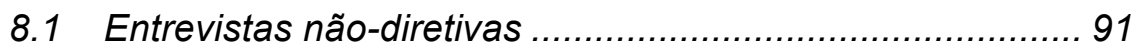

8.1.1 Participantes das entrevistas não-diretivas ............ 91

8.1.2 Resultados da análise de conteúdo ..................... 93

8.2 Questionários............................................................ 100

8.2.1 Participantes dos questionários ........................... 100

8.2.2 Resultados dos questionários ............................. 104

8.3 Entrevistas focadas ................................................... 120

8.3.1 Participantes das entrevistas focadas ................... 120

8.3.2 Análise de conteúdo: categorização ...................... 124

8.3.3 Resultados e discussão ....................................... 128

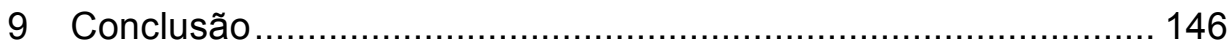

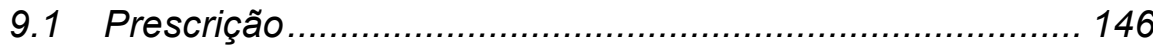

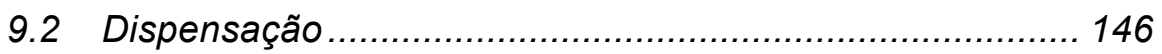

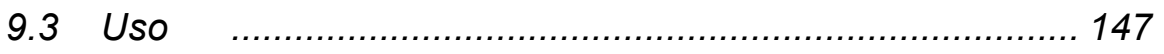

9.3.1 Recursos de identificação

dos medicamentos e apoio à administração: .................... 147

9.4 Baixa escolaridade ...................................................... 151

9.5 Medicamentos acessíveis

e empoderamento do paciente ................................................... 152

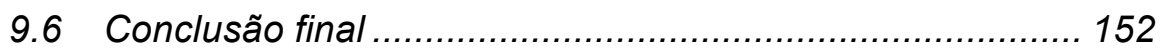

10 Referências bibliográficas................................................... 155 
11 Apêndices

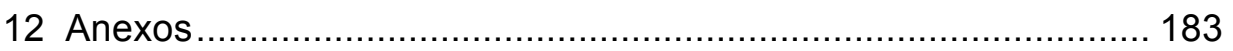




\section{Introdução}

Esta tese de doutorado está inserida na linha de pesquisa Ergonomia e Usabilidade do Programa de Pós-Graduação em Design da Pontifícia Universidade Católica do Rio de Janeiro. É uma pesquisa descritiva, e foi desenvolvida entre os anos de 2008 e 2012.

O presente trabalho é um desdobramento da pesquisa realizada no curso de mestrado, quando se investigou os problemas de legibilidade e leiturabilidade enfrentados por pacientes cardiopatas no uso das bulas de medicamentos.

As doenças crônicas afetam atualmente $40 \%$ da população brasileira e são responsáveis por mais de $70 \%$ das mortes no país totalizando $75 \%$ dos gastos com saúde.

As doenças crônicas ainda afetam desigualmente a população brasileira crescendo entre os mais desfavorecidos socialmente.

$\mathrm{O}$ atendimento das doenças crônicas deve ser diferente daquele das doenças agudas. Nele, o paciente auto-administra o seu tratamento, uma vez que a maior parte do tempo esse cuidado ocorre fora do ambiente hospitalar. Para que o paciente auto-administre seu tratamento de maneira consciente, ele deve ter informações suficientes a respeito da sua enfermidade e dos aspectos que envolvem seu tratamento, sendo a utilização de medicamento tarefa fundamental no controle de enfermidades crônicas.

A utilização de medicamentos - parte do ciclo de assistência farmacêutica em que paciente entra em contato diretamente - é composta de três etapas: prescrição, dispensação e uso.

Para que a utilização de medicamentos seja efetiva do tratamento de doenças, ou seja, haja o controle da enfermidade crônica, é necessário que a prescrição seja adequada e que o paciente esteja apto a administrar o tratamento de maneira consciente. 
A comunicação é elemento essencial no ciclo de utilização de medicamentos. Problemas neste processo são identificados como principais obstáculos para a utilização efetiva dos medicamentos, especialmente nas parcelas onde as enfermidades crônicas e múltiplas mais crescem: população idosa, de renda e escolaridade mais baixas.

O problema investigado pela presente pesquisa diz respeito à comunicação deficiente no ciclo de utilização de medicamentos, - principalmente quando os pacientes têm baixa escolaridade e renda - comprometendo a capacidade do paciente em auto-administrar seu tratamento e, consequentemente, comprometendo sua eficácia.

Esta pesquisa tem como hipótese que problemas na comunicação presente no ciclo de utilização de medicamentos no tratamento de enfermidades crônicas prejudicam a autoadministração consciente dos medicamentos por pacientes crônicos/seus acompanhantes, sendo a variável independente os problemas na comunicação presente no ciclo de utilização no tratamento de enfermidades crônicas e a variável dependente a autoadministração consciente dos medicamentos por pacientes crônicos/seus acompanhantes.

O objetivo geral desta pesquisa é descrever a comunicação presente no ciclo de utilização de medicamentos, sendo os objetivos específicos: levantar dados a respeito dos problemas de comunicação presentes no ciclo utilização de medicamentos e identificar a rotina do usuário para lidar com esses problemas.

Os métodos e técnicas utilizados neste estudo foram: elaboração de referencial teórico, entrevistas não-diretivas com pacientes com doenças cardiovasculares, questionários com pacientes com de doenças cardiovasculares autorreferidas e entrevistas focadas com pacientes com doenças crônicas autorreferidas, moradores da comunidade da Mangueira.

A seguir é apresentado um quadro dos capítulos, a partir de seus objetivos e conteúdo. 


\begin{tabular}{|c|c|c|c|}
\hline & Capítulo & Objetivo & Conteúdo \\
\hline 2 & $\begin{array}{l}\text { Doenças crônicas } \\
\text { e atenção centrada } \\
\text { no paciente }\end{array}$ & $\begin{array}{l}\text { Definir doenças crônicas e } \\
\text { apresentar dados relativos a } \\
\text { esta enfermidade que } \\
\text { apresentem sua relevância e } \\
\text { apontem caminhos para uma } \\
\text { melhor assistência em saúde. }\end{array}$ & $\begin{array}{l}\text { Dados demográficos e } \\
\text { epidemiológicos a respeito } \\
\text { de doenças crônicas. } \\
\text { Dados relativos aos custos com } \\
\text { doenças crônicas. } \\
\text { Diferenças no atendimento a } \\
\text { doenças agudas e crônicas. } \\
\text { Apresentação do modelo de } \\
\text { cuidado crônico. }\end{array}$ \\
\hline 3 & $\begin{array}{l}\text { Utilização } \\
\text { de medicamentos }\end{array}$ & $\begin{array}{l}\text { Apresentar o campo da } \\
\text { assistência farmacêutica e } \\
\text { utilização de medicamentos a } \\
\text { partir de seus elementos } \\
\text { fundamentais para que haja o } \\
\text { uso racional dos } \\
\text { medicamentos. }\end{array}$ & $\begin{array}{l}\text { Ciclo de assistência farmacêutica } \\
\text { e as suas etapas. } \\
\text { Utilização de medicamentos e } \\
\text { suas etapas. } \\
\text { Dados relativos ao uso de } \\
\text { medicamentes e problemas } \\
\text { enfrentados pelos usuários. }\end{array}$ \\
\hline 4 & $\begin{array}{l}\text { Ergonomia } \\
\text { e assistência } \\
\text { em saúde }\end{array}$ & $\begin{array}{l}\text { Apresentar o campo da } \\
\text { ergonomia e sua relevância } \\
\text { para o enfrentamento dos } \\
\text { problemas no atendimento à } \\
\text { saúde. }\end{array}$ & $\begin{array}{l}\text { Definição de ergonomia e seus } \\
\text { campos de especialização. } \\
\text { Atuação e relevância da } \\
\text { ergonomia na melhoria da } \\
\text { assistência em saúde. }\end{array}$ \\
\hline 5 & $\begin{array}{l}\text { Modelagem } \\
\text { da comunicação }\end{array}$ & $\begin{array}{l}\text { Apresentar modelos de } \\
\text { comunicação que possam } \\
\text { contribuir para a sistematização } \\
\text { da comunicação na utilização } \\
\text { de medicamentos presentes no } \\
\text { tratamento de doenças } \\
\text { crônicas. }\end{array}$ & $\begin{array}{l}\text { Definição de comunicação. } \\
\text { Definição de modelagem da } \\
\text { comunicação. } \\
\text { Apresentação de quatro modelos } \\
\text { de comunicação. }\end{array}$ \\
\hline 6 & $\begin{array}{l}\text { Delineamento } \\
\text { da pesquisa }\end{array}$ & $\begin{array}{l}\text { Descrever o problema, } \\
\text { objetivo, } \\
\text { hipótese } \\
\text { e variáveis da } \\
\text { pesquisa }\end{array}$ & $\begin{array}{l}\text { Descrição da pesquisa } \\
\text { Apresentação da sistematização } \\
\text { de comunicação na utilização de } \\
\text { medicamentos utilizados na } \\
\text { análise realizada nesta pesquisa. }\end{array}$ \\
\hline 7 & $\begin{array}{l}\text { Métodos } \\
\text { e técnicas }\end{array}$ & $\begin{array}{l}\text { Apresentar os métodos } \\
\text { e técnicas utilizados. }\end{array}$ & $\begin{array}{l}\text { Descrição dos métodos } \\
\text { e técnicas utilizados na pesquisa: } \\
\text {-- Pesquisa bibliográfica; } \\
\text {-- Entrevistas não-diretivas; } \\
\text {-- Questionários; } \\
\text {-- Entrevistas focadas. }\end{array}$ \\
\hline 8 & $\begin{array}{l}\text { Resultados } \\
\text { e discussão }\end{array}$ & $\begin{array}{l}\text { Apresentar e analisar } \\
\text { os dados obtidos } \\
\text { pelos métodos e técnicas } \\
\text { aplicados. }\end{array}$ & $\begin{array}{l}\text { Apresentação e análise } \\
\text { dos dados quantitativos } \\
\text { e dos comentários } \\
\text { dos respondentes } \\
\text { às entrevistas realizadas. }\end{array}$ \\
\hline
\end{tabular}




\begin{tabular}{|l|l|l|}
\hline Capítulo & \multicolumn{1}{|c|}{ Objetivo } & Conteúdo \\
\hline $\mathbf{9} \quad$ Conclusão & $\begin{array}{l}\text { Discussões } \\
\text { dos resultados } \\
\text { apresentados. } \\
\text { Conclusões } \\
\text { e desdobramentos. }\end{array}$ & \\
\hline
\end{tabular}




\section{Doenças crônicas e atenção centrada no paciente}

As doenças crônicas representam um grande desafio global para o desenvolvimento neste século. A Organização Mundial de Saúde estima que as doenças crônicas não transmissíveis foram responsáveis por $60 \%$ das mortes ocorridas no ano de 2005 (OMS 2005b, p.2-3; 2008, p.9). A incidência deste tipo de doença vem aumentando rapidamente, especialmente em países de renda média e baixa e em populações mais pobres dentro de um mesmo país. Das 58 milhões de mortes ocorridas no ano de 2005, 35 milhões seriam por doenças crônicas e 80\% dessas ocorreram em países de renda baixa, ou média, como o Brasil (OMS, 2005b, p.1;2008, p.9).

\subsection{Definição}

A definição de doenças crônicas varia entre diferentes autores. Wagner (2004) define doença crônica de maneira bem ampla, abrangendo qualquer doença que requeira atividades e respostas dos pacientes e pessoas que colaboram com seu tratamento, assim como uma resposta do sistema de saúde ao longo do seu curso. Nesta definição estão incluídas tanto as doenças físicas mais tradicionais, como diabetes, hipertensão e doenças do coração, como também transtornos mentais crônicos, doenças de comportamento, como déficit de atenção em crianças. Segundo este autor, este conceito pode ser aplicado, inclusive, a comportamentos nocivos como o tabagismo.

Segundo os descritores em ciências de saúde $-\operatorname{DeCS}^{1}-$ as doenças crônicas apresentam uma ou mais das seguintes características:

são permanentes, deixam incapacidade residual, são causadas por alteração patológica não reversível, requerem treinamento especial do

1 DesCs / BVS - Biblioteca Virtual em saúde. Disponível em : < http://decs.bvs.br/cgibin/wxis 1660.exe/decsserver/> Acesso em 23 set. 2012. 
paciente para reabilitação; pode-se esperar um longo período de revisão, observação e cuidado.

Nolte e McKee (2008a, p.1) ressaltam que o que há em comum nas diferentes definições de doença crônica é que elas requerem uma resposta complexa durante um longo período. Os autores lembram que esta resposta envolve elementos coordenados de uma vasta gama de profissionais de saúde, acesso a medicamentos essenciais e sistemas de monitoramento e que esses elementos precisam ser encaixados em um sistema que promova o empoderamento ${ }^{2}$ do paciente.

\subsection{Doenças crônicas no Brasil}

A população brasileira vem sofrendo um rápido processo de envelhecimento. A pirâmide etária brasileira, que em 2010 ainda apresentava aspecto triangular, em 2025 já terá o seu aspecto alterado com o alargamento do seu topo (IBGE, 2008).

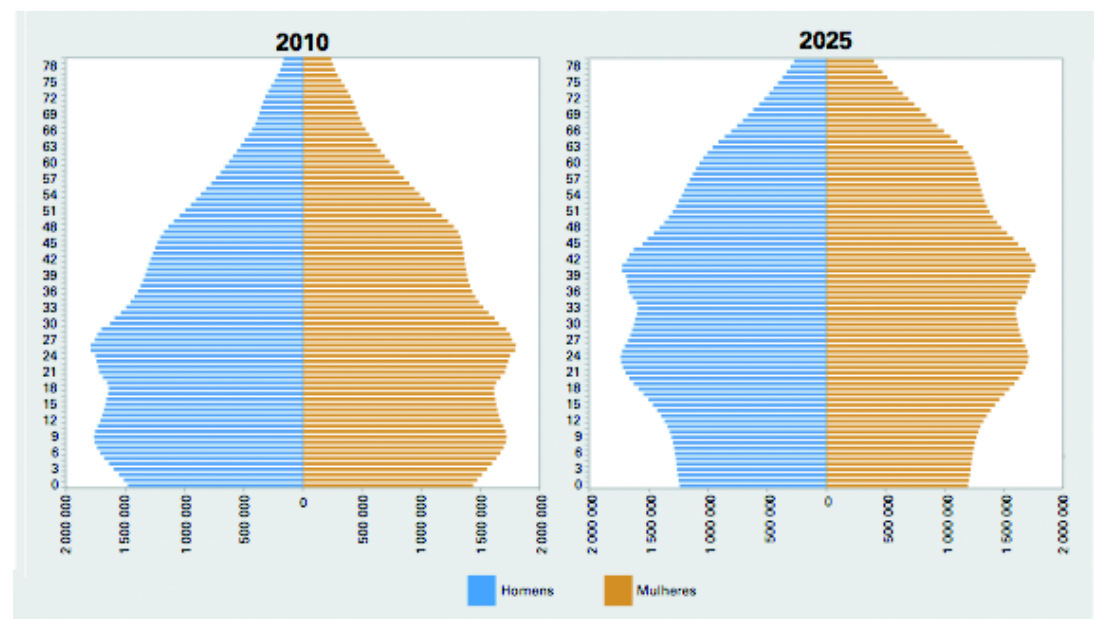

Gráfico 1: Projeção da composição absoluta da população brasileira para os anos de 2010 e 2050. Fonte: IBGE, 2008, p60. 
O índice de envelhecimento da população brasileira aponta que, em 2008, para cada 100 crianças até 14 anos, havia 24,7 habitantes de 65 anos ou mais. Entre 2035 e 2040, segundo projeções do IBGE, já haverá uma população idosa $18 \%$ maior do que a de crianças (IBGE, 2008).

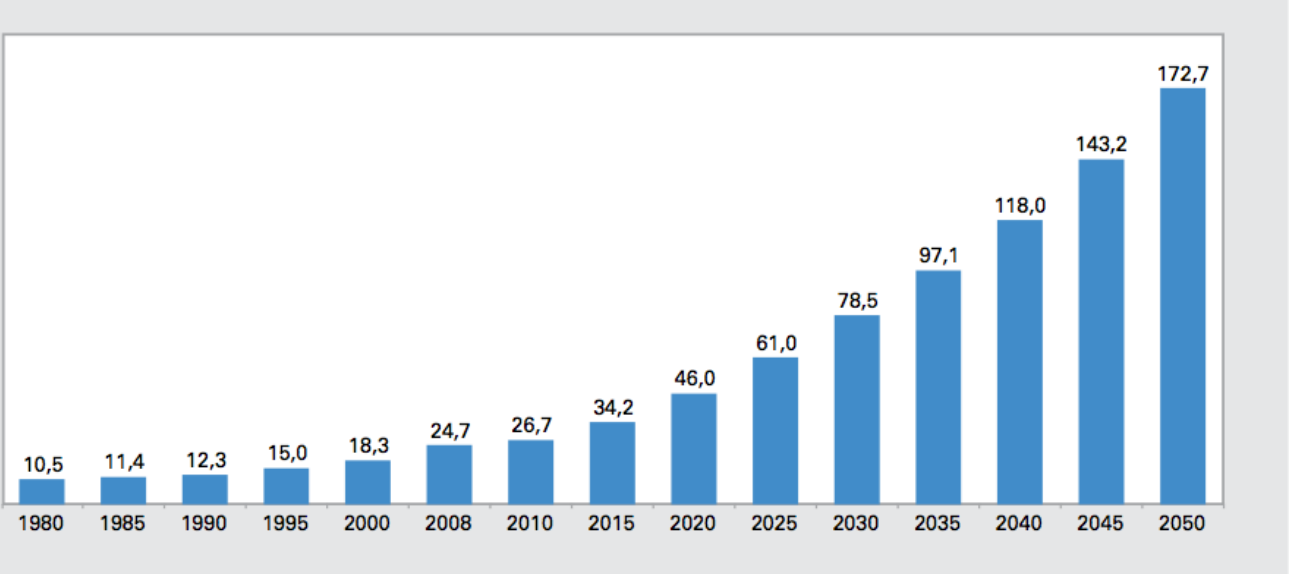

Gráfico 2: Evolução do índice envelhecimento da população - Brasil - 1980/2050. Fonte: IBGE, 2008, p.55.

A este processo de transição demográfica está associado um processo de transição epidemiológica. Se em 1930, as doenças não-transmissíveis representavam $46 \%$ das mortes em capitais brasileiras, ocorreu uma redução progressiva dessas causas e em 2003 este tipo de enfermidade representava cerca de 5\% das mortes. Já as doenças cardiovasculares que na década de 1930 representavam 12\% das mortes, no ano de 2005 eram responsáveis por quase um terço dos óbitos, sendo a principal causa de morte em todas as regiões brasileiras. (BRASIL, 2005, p.17).

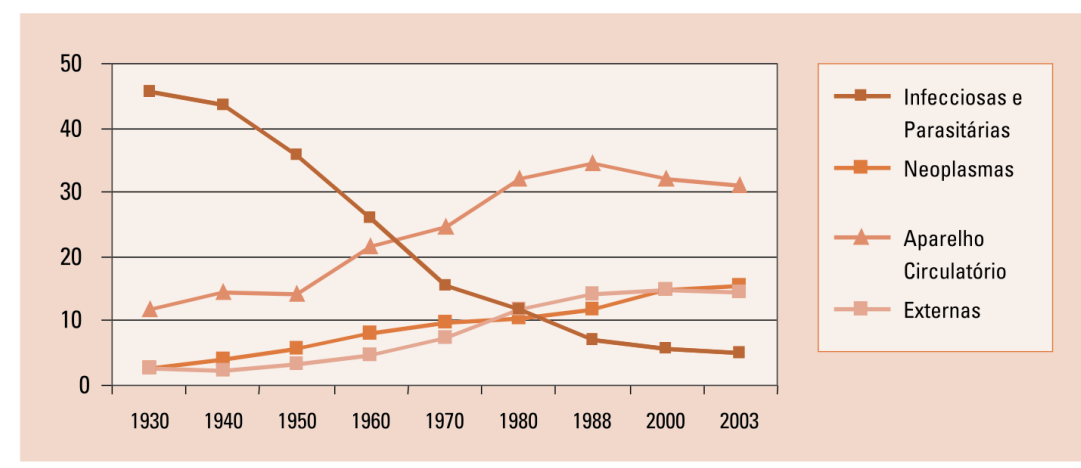

Gráfico 3: Evolução da mortalidade populacional (\%) segundo as causas, Brasil - 1930 a 2003 Fonte: Barbosa et al, 2003 apud Brasil, 2005, pl8. 
No ano de 2003, dados do PNAD mostraram que 40\% da população brasileira com mais de 18 anos apresentaram pelo menos uma doença crônica (BARROS et al., 2006, p.920) e, segundo dados do ano de 2011 da Organização Mundial de Saúde, as doenças crônicas foram responsáveis por $74 \%$ das mortes no Brasil.

\section{Mortalidade proprocional (\% do total de mortes, todas as idades)}

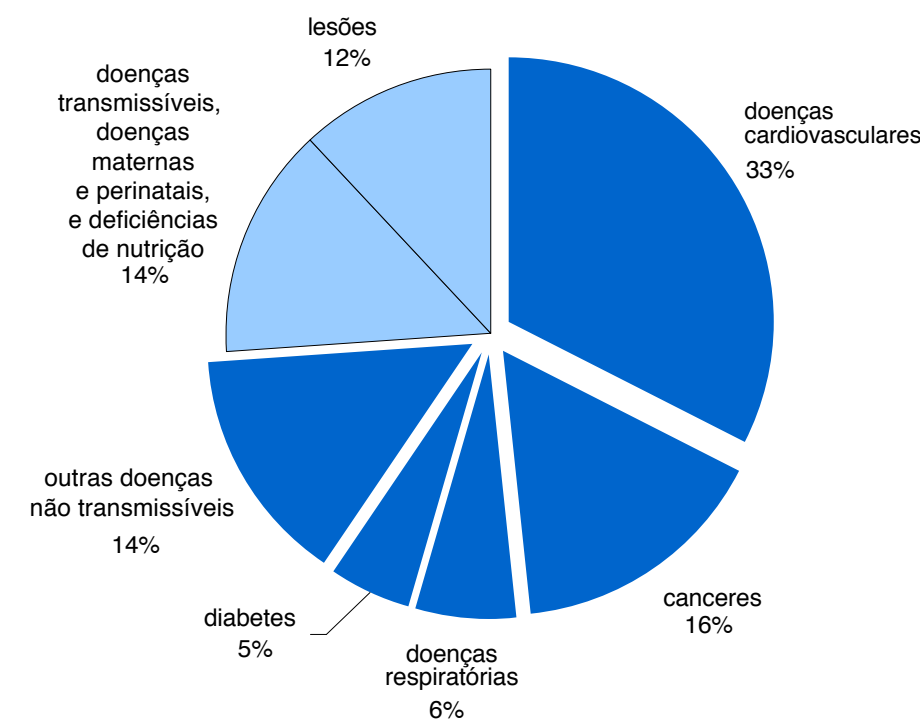

Estima-se que as doenças crônicas sejam a causa de $74 \%$ tototal de mortes.

Gráfico 4: Mortalidade proporcional no Brasil, por causa. Fonte: NCD Country Profiles (OMS, 201 l, tradução nossa).

O Ministério da Saúde compreende que o investimento em prevenção das doenças crônicas não-transmissíveis representa o investimento de mais custo efetivo entre todos aqueles do setor saúde. Ainda segundo o Ministério da Saúde, o estímulo de práticas de prevenção primária e a assistência aos já doentes são dever do Estado e necessários para a sustentabilidade do próprio sistema de saúde. (BRASIL, 2005, p.59). 
Os custos relacionados às doenças crônicas ocorrem devido a mortes prematuras e incapacitação de pessoas com enfermidades crônicas. Malta et al utilizam o termo "novas epidemias" se referindo às doenças crônicas não transmissíveis e afirmam que seu enfrentamento demanda significativos investimentos em pesquisa, vigilância, prevenção, promoção da saúde e defesa de uma vida saudável (2006, p.48).

Segundo o Ministério da Saúde, a assistência ambulatorial encontra-se no campo da atenção pré-hospitalar em saúde e é definido como o "conjunto de procedimentos médicos e terapêuticos de baixa complexidade, possíveis de realização em ambulatórios e postos de saúde.” (BRASIL, 2004, p.21). Este tipo de atendimento é fundamental no tratamento de doenças crônicas. Se feito de maneira efetiva, melhora os resultados clínicos do paciente e reduz o número de hospitalizações.

Para avaliar a qualidade deste atendimento existe um indicador denominado ambulatory care sensitive conditions. Em português, o termo é traduzido para condições sensíveis à atenção ambulatorial, internações potencialmente evitáveis $^{3}$, ou internações por condições sensiveis à atenção primária ${ }^{4}$. Perpétuo e Wong afirmam que o termo, também chamado de "internações potencialmente evitáveis" diz respeito a um conjunto de doenças que se abordadas de maneira apropriada, tanto em termos de promoção e prevenção, quanto de tratamento precoce e acompanhamento ambulatorial, dificilmente progrediriam a ponto de exigir internação.” (PERPETUO; WONG, 2006).

Alfradique et al (2009, p.1337) explicam que este indicador se refere, no caso das doenças crônicas, ao seu acompanhamento, evitando assim o agravamento das condições de saúde do paciente, levando este a uma internação que poderia ter sido evitada. (Alfradique et al, 2009, p.1346). Os autores esclarecem que taxas altas de internações sensíveis à atenção primária podem indicar problemas de acesso ao serviço de saúde ou ao desempenho deste serviço. O índice funciona, portanto, como sinal de alerta na atenção à saúde.

3 Perpetuo e Wong (2006).

4 Oliveira, Simões e Andrade (2007). 
Vinte e quatro por cento do total de hospitalizações no setor público entre os anos de 1999 e 2007 no Brasil foram por condições sensíveis à atenção ambulatorial (Macinko et al, 2011, p.1966).

Segundo Banco de dados do Sistema Único de Saúde - DataSUS, só os casos de hipertensão, insuficiência cardíaca e diabetes representam 20,7\% do total de internações sensíveis à atenção primária (ALFRADIQUE et al. 2009 p.1344). Por volta de $80 \%$ do total de internações que ocorrem no Brasil, são pagas pelo governo brasileiro; estes gastos consomem quase $70 \%$ de todas as despesas nacionais com saúde. (MACINKO et al., 2011 p. 1963).

\subsection{Doenças crônicas e pobreza}

O aumento das doenças crônicas em países de renda média e baixa vem aumentando devido à crescente globalização, urbanização, ocidentalização e envelhecimento das populações desses países. (OMS, 2007, p39.). Este é um dos maiores desafios para o desenvolvimento no século XXI (OMS, 2008, p.9) e é ainda mais decisivo ao considerarmos que a população onde essas enfermidades mais aumentam é a composta por indivíduos em posições sociais menos favorecidas. (OMS, 2008, p33)

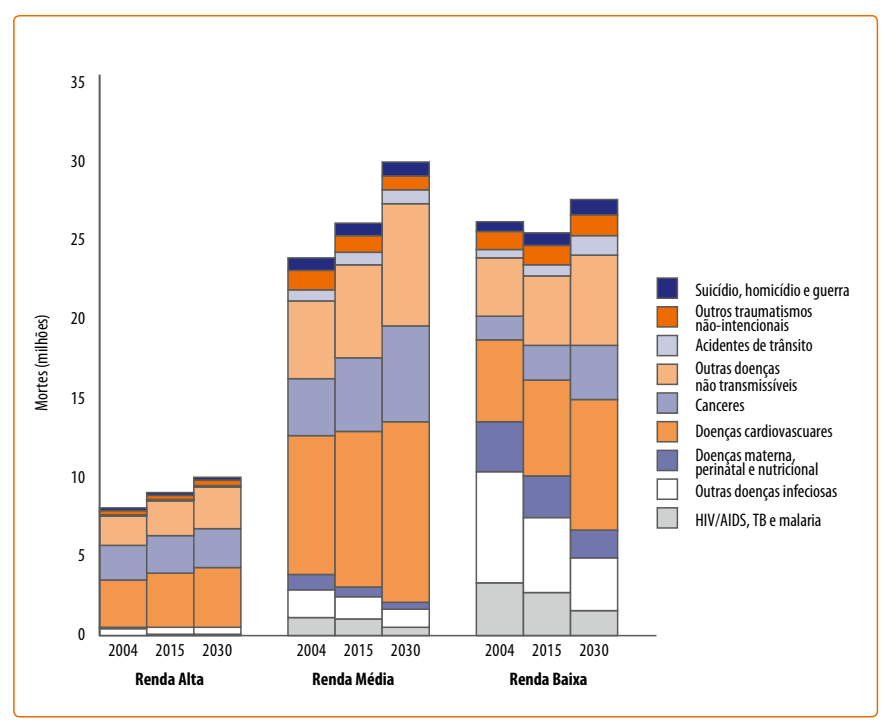

Gráfico 5: Projeção de mortes por cause para países de rendas alta, média e baixa. Fonte: The global Burden of Disease: 2004 update. Genebra: OMS, 2008, p. 24, tradução nossa. 
No Brasil, essa desigualdade também ocorre, sendo a desigualdade social fator significativo para a presença de doenças crônicas, como observado nos comentários da Pesquisa Nacional de Amostra Domiciliar. Barros (2008), ao realizar uma análise dos dados do PNAD 2008 relativos às doenças crônicas, identificaram desigualdades sociais significativas na prevalência de doenças crônicas.

Além de ser mais acometida por doenças crônicas, a população menos favorecida socialmente também tem cuidado reduzido à enfermidade, entrando num ciclo vicioso, que tem no seu início a privação material, e como fim as menores oportunidades de se evitar complicações.

\section{Da pobreza à doença crónica}

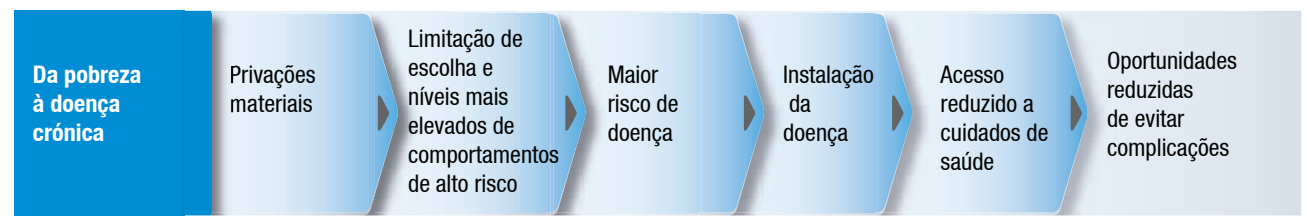

Gráfico 7: Da pobreza à doença crônica.

Fonte: ORGANIZAÇÃO MUNDIAL DE SAÚDE. Vigilância global, prevenção e controle das doenças respiratórias crônicas: Uma abordagem integradora, 2007, a partir de Beaglehole, R. et al. Preventing chronic diseases: a vital investment. Genebra, OMS, 2005.

A baixa escolaridade, fator diretamente associado à baixa renda (BRASIL, 2005, p.24), é ainda apontado como obstáculo à efetividade do tratamento. (KRIPALANI et al. 2006; AKICI et al, 2004, WOLF, 2004).

O Ministério da Saúde, na ratificação do seu plano de enfrentamento de doenças crônicas, atesta que as enfermidades crônicas atingem principalmente populações de baixa escolaridade e baixa renda, e que é nessas populações que as desigualdades no acesso à saúde acompanham esses pacientes mais vulneráveis, e há urgência em se tomar atitudes efetivas a esse respeito:

[...] existem significativas diferenças regionais, de gênero, entre grupos etnicorraciais, ciclos de vida e de estrato socioeconômico na distribuição da carga das DCNT e no acesso à sua prevenção e controle no país, com evidente prejuízo das pessoas em condições de maior vulnerabilidade social, configurando uma situação importante de iniquidade em saúde que necessita ser superada (Brasil, 2011, p.1). 


\subsection{Modelo de atendimento em saúde para cuidado crônico}

Os custos sociais e financeiros associados à incidência de doenças crônicas vêm chamando a atenção e representam grande desafio, tanto para países mais ricos como mais pobres.

Ocorre que o volume de dinheiro gasto para o tratamento dessas enfermidades não é revertido com eficiência em benefícios clínicos para esses pacientes.

Nos EUA, onde os gastos com tratamento de doentes crônicos são de aproximadamente 1 trilhão de dólares, mais da metade destes pacientes não recebem atendimento adequado e, consequentemente, não têm os resultados clínicos satisfatórios. Estima-se, ainda, que as falhas na qualidade do atendimento a doentes crônicos nos EUA levam a 57.000 mortes evitáveis e 11 bilhões de dólares em perda de produtividade por ano (WAGNER et al., 2004).

Pesquisas recentes sugerem ainda que "menos da metade dos pacientes norte-americanos com hipertensão, depressão, diabetes e asma estão recebendo tratamento apropriado" (WAGNER et al, 2001, 64).

A ineficiência no tratamento a doentes crônicos se relaciona diretamente com o modelo de sistema de saúde adotado, estruturado para o tratamento de enfermidades agudas, e inadequado para o perfil atual, com maior volume de enfermidades crônicas.

O aumento da prevalência de doenças crônicas representa grandes desafios para os sistemas de saúde. Doenças crônicas requerem modelos complexos de assistência, envolvendo a colaboração entre profissões e instituições que são tradicionalmente separadas. $\mathrm{O}$ atendimento à saúde ainda é estruturado no modelo para atendimento de problemas agudos e episódicos de saúde e mal equipado para as necessidades contínuas dos pacientes com enfermidades crônicas. (NOLTE; MCKEE, 2008b).

Wagner (2001) apresenta a diferença entre os tipos de tratamento crônico e agudo. Apesar do tipo de enfermidade prevalente ter se alterado nas últimas décadas, o modelo de atendimento e a participação do paciente em seu tratamento continuam obedecendo aos critérios de atendimento agudo, conforme apresenta Wagner (2001): 
Nosso sistema de saúde foi historicamente organizado para responder rápida e eficientemente a qualquer doença aguda ou lesões que aparecerem. O foco era no problema imediato, sua rápida definição e exclusão de diagnósticos mais sérios e a iniciação de tratamento profissional. O papel do paciente era bastante passivo. Uma vez que a duração do tratamento era de dias ou semanas, havia pouca urgência em se desenvolver habilidades de auto-administração do paciente ou programas de acompanhamento.[...]. A maior parte das práticas continua neste caminho apesar do rápido envelhecimento da população e o aumento da prevalência de doenças crônicas (WAGNER et a., 2001, p.68).

Os modelos de tratamento agudos de serviços representam, segundo a organização Mundial de Saúde, barreiras à adesão ao tratamento de doenças crônicas (OMS, 2001, p11.).

Segundo a Organização Mundial de Saúde (2001), para que se lide de maneira efetiva com as doenças crônicas é necessário um modelo diferente de cuidado. Isso ocorre pelas diferenças no tipo de enfermidade e tratamento entre enfermidades agudas e crônicas - sejam elas de origem transmissível ou não transmissível - que vão desde a sua duração ao papel desempenhado pelas pessoas envolvidas no tratamento.

As diferentes características entre os modelos de cuidado à saúde agudo e crônico vão desde o tempo de tratamento, ao papel desempenhado por paciente e profissionais de saúde, até o objetivo do tratamento. pois o próprio objetivo do tratamento agudo e crônico já difere essencialmente. No cuidado agudo, o objetivo é a cura; e no cuidado crônico, o controle da doença, o prolongamento da vida e o aumento da qualidade de vida, conforme apresentado na tabela abaixo. 


\begin{tabular}{|l|l|l|}
\hline & Cuidado agudo & Cuidado crônico \\
\hline $\begin{array}{l}\text { Objetivo principal } \\
\text { do tratamento }\end{array}$ & Cura & $\begin{array}{l}\text { Controle da doença; } \\
\text { Prolongamento da vida; } \\
\text { Aumento da qualidade de vida. }\end{array}$ \\
\hline Duração & Limitada & $\begin{array}{l}\text { Longo período, indefinido ou } \\
\text { por toda a vida. }\end{array}$ \\
\hline Conhecimento & $\begin{array}{l}\text { Centrado nos profissionais } \\
\text { de saúde. }\end{array}$ & $\begin{array}{l}\text { Profissionais de saúde. } \\
\text { Pacientes e familiares } \\
\text { compartilham conhecimento } \\
\text { complementar. }\end{array}$ \\
\hline $\begin{array}{l}\text { Tratamento } \\
\text { da doença }\end{array}$ & $\begin{array}{l}\text { Focada no tratamento agudo } \\
\text { e unicamente médico. }\end{array}$ & $\begin{array}{l}\text { Estratégia multimedicamentosa } \\
\text { e de autocuidado/autogestão } \\
\text { (self management), com } \\
\text { sistema de saúde apropriado, } \\
\text { apoio da família e da } \\
\text { comunidade. É comum a } \\
\text { presença de comorbidade. }\end{array}$ \\
\hline $\begin{array}{l}\text { Qualidade da } \\
\text { assistência } \\
\text { de saúde }\end{array}$ & $\begin{array}{l}\text { Normalmente abordagens } \\
\text { autossuficientes restritas a } \\
\text { cada instituição. }\end{array}$ & $\begin{array}{l}\text { Relevância de uma abordagem } \\
\text { de qualidade sistêmica. }\end{array}$ \\
\hline $\begin{array}{l}\text { Normalmente clínicos e } \\
\text { instituições clínicas. }\end{array}$ & $\begin{array}{l}\text { Largo espectro de serviços de } \\
\text { saúde, serviços à comunidade } \\
\text { e saúde da família. }\end{array}$ \\
\hline
\end{tabular}

Tabela 1: Comparação dos modelos de cuidado agudo e crônico.

Fonte: Organização Mundial de Saúde, 2001, p.12, tradução nossa.

A demanda pela adequação do modelo de saúde para que este apresente efetividade no tratamento de enfermidades crônicas é evidente. As alterações no perfil de saúde da população demandam um novo modelo adequado ao tratamento para doenças crônicas, o qual tem como fator decisivo a autonomia do usuário (MALTA et al., 2011).

Deber (1994) afirma que, historicamente, na relação médico-paciente, era considerado que o médico agia segundo os interesses do paciente e direcionava o tratamento, agindo em favor do paciente. Mas o autor pondera que "beneficência não é mais o suficiente para as bases éticas e legais atuais; o respeito pela autonomia é imprescindível, sendo necessário, portanto, a participação do paciente" (DEBER, 1994, p.171, tradução nossa) 


\subsection{O Modelo de Cuidado Crônico}

O Ministério da Saúde apresentou, no ano de 2011, o Plano de Enfrentamento das Doenças Crônicas não Transmissíveis do Brasil (BRASIL, 2011). Neste documento, são apresentados o impacto das doenças crônicas no país, assim como estratégias efetivas de prevenção e cuidado para o seu enfrentamento. No documento, é apresentado o Modelo de Cuidado Crônico.

Este se baseia na premissa de que, para que haja a melhoria dos resultados de tratamento de enfermidades crônicas, há necessidade de uma mudança em todo o sistema de saúde. Esta necessidade foi identificada após um grande estudo do Comitê de qualidade do atendimento em Saúde, nos Estados Unidos da América - Committee on Quality of Health Care on America (2001) - a respeito da qualidade do sistema de saúde dos EUA, intitulado Passando Pelo Abismo da Qualidade: Um Novo Sistema de Saúde para o Século XXI (Crossing The Quality Chasm: A New Health System For The 21st Century). O estudo concluiu que não adianta dedicar mais esforço para a melhora da qualidade do atendimento à saúde. O que deve ser feito é mudar o sistema.

Baseado nesta premissa, e a partir da categorização realizada por Renders et al. (2001) $)^{5}$, Wagner e sua equipe desenvolveram o Modelo de cuidado crônico, descrito pelo autor como uma guideline baseada em evidências: uma síntese de mudanças no sistema para ser usada para guiar avanços na qualidade" (WAGNER et al, 2011, p.69, tradução nossa).

\footnotetext{
5 Renders et al. (2001) pesquisaram a efetividade de intervenções na melhoria dos resultados do tratamento de diabetes. As intervenções foram divididas em três categorias profissionais de saúde, apoio à auto-administração (paciente), self management support (paciente), e apoio ao time de profissionais, envolvendo qualquer tipo de mudança na organização. A pesquisa concluiu que, individualmente, o tipo de intervenções que causavam uma melhora mais efetiva foram aquelas que passavam por mais de uma das etapas no sistema, ou seja, intervenções transversais no sistema. Isoladamente, as intervenções que tiveram maior efeito, ainda que não suficientes, foram na categoria auto-gerenciamento do paciente, ou seja, intervenções para aumentar o domínio e conhecimento do paciente.
} 


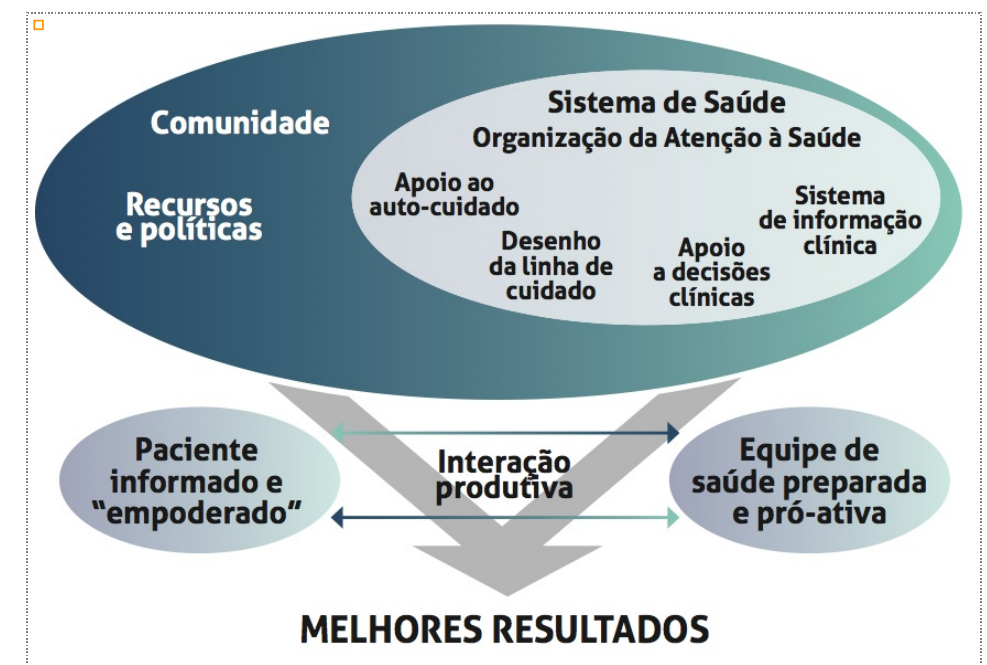

Figura 1: Abordagem integral da linha de cuidado em doenças crônicas. Fonte: Brasil, 2011, p.58.

O sistema de saúde está na oval maior, que contem as 5 categorias de mudanças que devem ocorrer para que a interface entre paciente e equipe de saúde se modifique.

Segundo Wagner (2004), o modelo de Cuidado Crônico começa "em baixo", ou seja, o que está em questão é a melhoria nos resultados clínicos do paciente individualmente.

Para se melhorar os resultados é preciso mudar toda a natureza da interface entre paciente e equipe de saúde. Para que isso aconteça é preciso um sistema mais facilitador da equipe de saúde.

Partindo da interface entre paciente e equipe profissional de saúde, temos, como elemento essencial, a interação produtiva. Wagner et al. (2001) definem interação produtiva como aquela que vai ao encontro das necessidades de informações clínicas e comportamentais, baseadas em evidência e apoio para que os pacientes se tornem melhores auto-administradores da sua saúde.

Wagner explica que, para que ocorra a interação produtiva, é necessário que haja, de um lado, a equipe profissional preparada, não no sentido de atender numa emergência, mas preparada para dar conta do atendimento atualizado para doenças crônicas. Isto significa que, no momento da interação, os profissionais têm: a informação do paciente; o apoio à decisão, ou seja, o conhecimento da melhor evidência científica para o cuidado daquele paciente específico, e os recursos necessários para fornecer o atendimento de qualidade. 
E do outro lado da interação é necessário um paciente ativado $e$ empoderado ou informado. Significa que ele deve ter informações suficientes para tomar decisões relacionadas à sua saúde com discernimento. Pacientes também precisam ser "empoderados" ao entenderem a importância do seu papel na administração da enfermidade. A partir dessa relação, ocorreria o atendimento de alta qualidade, ou seja:

\begin{abstract}
O atendimento de alta qualidade em doenças crônicas é caracterizado por uma interação produtiva entre equipe profissional e pacientes, que consistentemente fornecem avaliação e apoio para autoadministração, otimização do tratamento e acompanhamento associados a boas respostas clínicas (WAGNER et al., 2001, p.68).
\end{abstract}

\title{
2.6 Auto-administração
}

Autoadministração no tratamento de doenças crônicas é definida por Lorig como o aprendizado e prática das capacidades necessárias para conduzir uma vida ativa e emocionalmente satisfatória diante de uma doença crônica (LORIG, 1993, p,1). Para que a autoadministração ocorra efetivamente, e com isso haja melhora dos resultados clínicos, é necessário, além da transferência do conhecimento relativo ao tratamento, a colaboração entre o assistente de saúde e o paciente. (BODENHEIMER et al., 2005 p. 17). Para que se alcancem os melhores resultados no tratamento das doenças crônicas não é suficiente que sejam feitos todos os exames certos e que os tratamentos sejam prescritos de maneira correta; é preciso que se melhore a habilidade e interesse do paciente em administrar seu próprio tratamento. Bodenheimer e Grumbach lembram que a autoadministração ocorre independente da preparação ou não do paciente para esta tarefa, e apresenta o conceito de auto-eficácia, incorporando, além da competência de identificar problemas, a capacidade de resolvê-los:

[...] pacientes com doenças crônicas tomam decisões diárias - autoadministram - suas enfermidades. Esta realidade introduz um novo paradigma nas doenças crônicas: a parceria paciente-profissional, envolvendo atenção colaborativa e educação para a autoadministração. A instrução para a autoadministração complementa a instrução tradicional ao paciente, ao apoiar os pacientes para viver com a melhor qualidade possível com a sua doença crônica. Enquanto a instrução tradicional ao 
paciente oferece informação e habilidades técnicas, a instrução para a auto-administração ensina habilidades para resolução de problemas. Um conceito central em autoadministração a auto-eficácia - confiança para saber realizar o comportamento necessário para alcançar o objetivo desejado. A auto-eficácia é aprimorada, quando os pacientes conseguem resolver problemas identificados pelo próprio paciente (BODENHEIMER; GRUMBACH, 2007. p. 79, tradução nossa).

Ainda segundo os autores, a autoadministração é qualquer atitude - de realização ou não - de uma atividade diária para "prevenir, controlar ou reduzir o impacto de uma doença crônica. A partir disto, o que deve ser feito é capacitar, motivar e auxiliar o paciente a tomar decisões diárias que favoreçam a sua saúde, sendo assim "bons auto-administradores". E para serem bons autoadministradores os pacientes devem ter um entendimento da enfermidade que se deseja prevenir ou melhorar e estarem motivados para assumirem comportamentos saudáveis. Portanto, para ser bom auto-administrador, o indivíduo deve estar informado e empoderado. (BODENHEIMER; MERRY, 2007, p.79-80).

Diferente do que ocorre atualmente, o paciente crônico deve estar informado, ou seja, ter informação suficiente para tomar decisões conscientes a respeito de sua enfermidade e estarem empoderados a partir da compreensão da relevância do seu papel na administração de sua enfermidade. (WAGNER, 2007).

Malta e Merhy (2010) enfatizam a relevância da autoadministração no tratamento de doenças crônicas, chamando atenção para a necessidade de uma revisão das estratégias de trabalho para favorecer o empoderamento do paciente brasileiro:

O elemento-chave consiste em fortalecer a capacidade de o usuário cuidar de si, o que vai muito além de um simples autocuidado protocolado dos portadores de DCNT [doença crônica não transmissível], estimulando seu empoderamento, suas escolhas, suas opções. A sua autonomia é fundamental para fortalecer suas escolhas responsáveis, a sua qualidade de vida. E, por isso, devem-se revisar as estratégias de trabalho de grupo e de educação em saúde que vêm sistematicamente povoando nossas redes de saúde, que utilizam métodos ultrapassados que pouco contribuem para esses processos. Os caminhos clássicos de informações e educação tipo bancária devem ser substituídos, conforme já alertava há muito o educador Paulo Freire, em seus vários trabalhos e preleções. (MALTA; MERHY, 2010, p.246) 


\subsection{Conclusões}

As doenças crônicas são o fator mais importante na saúde pública a ser considerado em todo o mundo, principalmente em países de renda média e baixa, como o Brasil. Isso ocorre porque o país não conseguiu ainda superar outros obstáculos na área da saúde e se depara com um aumento de doenças que demandam uma nova estrutura no sistema de saúde. Soma-se a isto o fato das enfermidades crônicas estarem aumentando sua prevalência justamente nas parcelas mais carentes, de renda mais baixa, e menos escolarizada da população brasileira, criando-se assim um ciclo de piora na qualidade de saúde do indivíduo e aumento das internações evitáveis, com sobrecarga, caros ao sistema de saúde brasileiro.

O tratamento de doenças crônicas apresenta necessidades distintas do tratamento de doenças agudas, mas é para o tratamento de enfermidades agudas que o sistema de saúde está estruturado. Há, portanto uma necessidade de reestruturação que passa pela própria estrutura do sistema de saúde, para que este tenha como objetivo a capacitação do paciente crônico para que seja um bom auto-administrador do seu tratamento. 


\section{Utilização de medicamentos}

Assistência Farmacêutica é uma política de saúde pública (BRASIL, 1998) composto de um conjunto de ações voltadas à promoção, proteção e recuperação da saúde, tanto individual como coletiva, tendo o medicamento como insumo essencial e visando ao acesso e uso racional do medicamento. Estas ações, segundo o Conselho Nacional de Saúde Pública a pesquisa, envolvem:

o desenvolvimento e a produção de medicamentos e insumos, bem como a sua seleção, programação, aquisição, distribuição, dispensação, garantia da qualidade dos produtos e serviços, acompanhamento e avaliação de sua utilização, na perspectiva da obtenção de resultados concretos e da melhoria da qualidade de vida da população. (BRASIL, 2004).

A assistência farmacêutica ocorre ciclicamente, em etapas sucessivas que dependem das outras para se realizar. O ciclo, representado na figura abaixo, é composto pelas etapas de seleção, suprimento, armazenamento, distribuição e utilização dos medicamentos, sendo nesta última etapa que ocorre a interação entre os profissionais de saúde e o usuário do medicamento (OLIVEIRA; BERMUDEZ; OSÓRIO DE CASTRO, 2007).

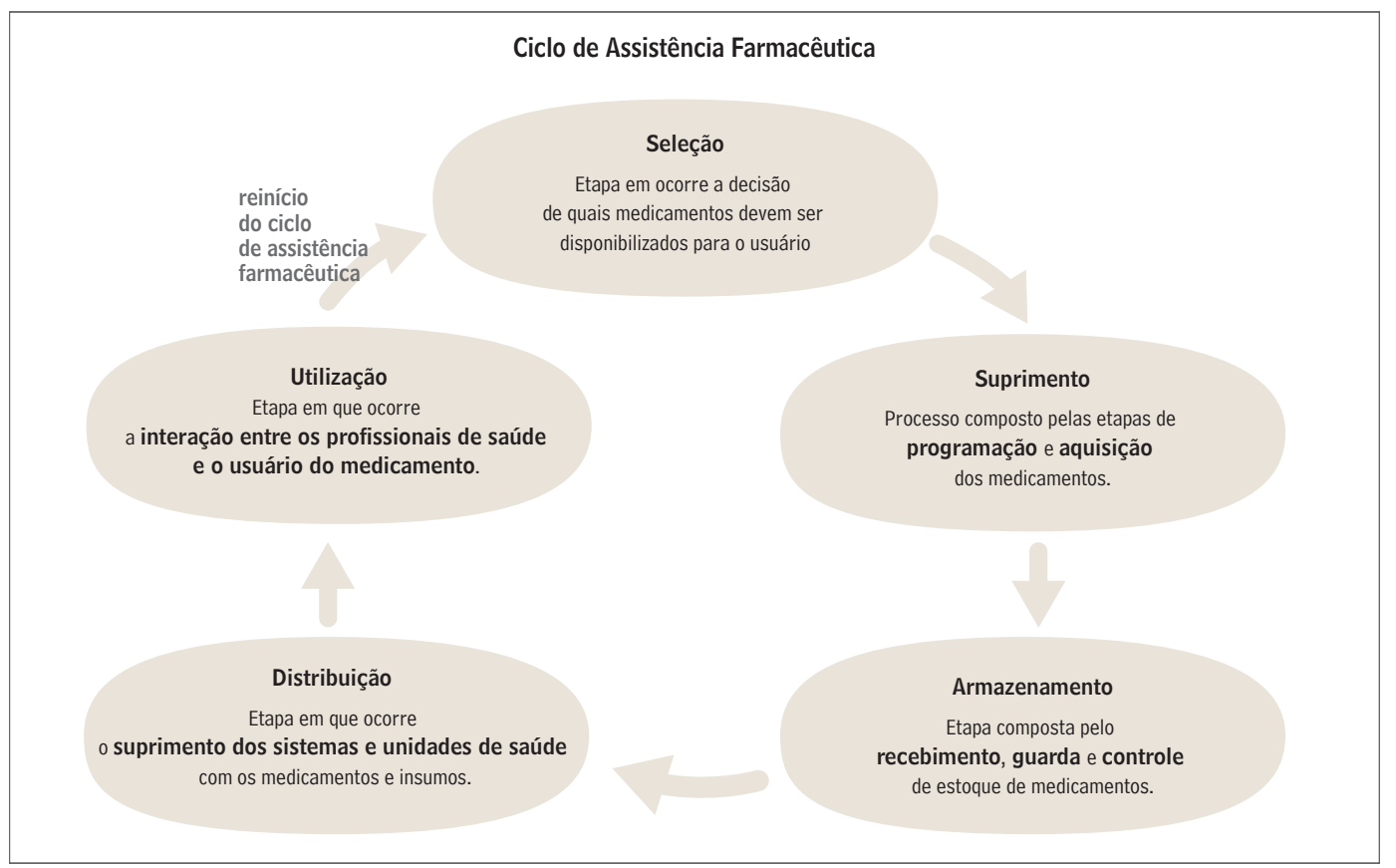

Figura 2: Ciclo de Assistência Farmacêutica.

A partir de Oliveira, Bermudez e Osório de Castro, 2007. 
É na etapa de utilização de medicamentos que há a interação da Assistência farmacêutica com o paciente. Esta interação se dá pela relação do paciente com os profissionais de saúde envolvidos como médicos, odontólogos, farmacêuticos, e profissionais de enfermagem. (PEPE; OSÓRIO DE CASTRO, 2000). Ela engloba todas as etapas da assistência farmacêutica em que há contato direto com o paciente/usuário.

A Utilização de medicamentos, como representado na na figura abaixo, ocorre também de maneira cíclica, sendo composta pelas fases de prescrição, dispensação e uso, quando se reiniciando o ciclo com o retorno do paciente ao prescritor.

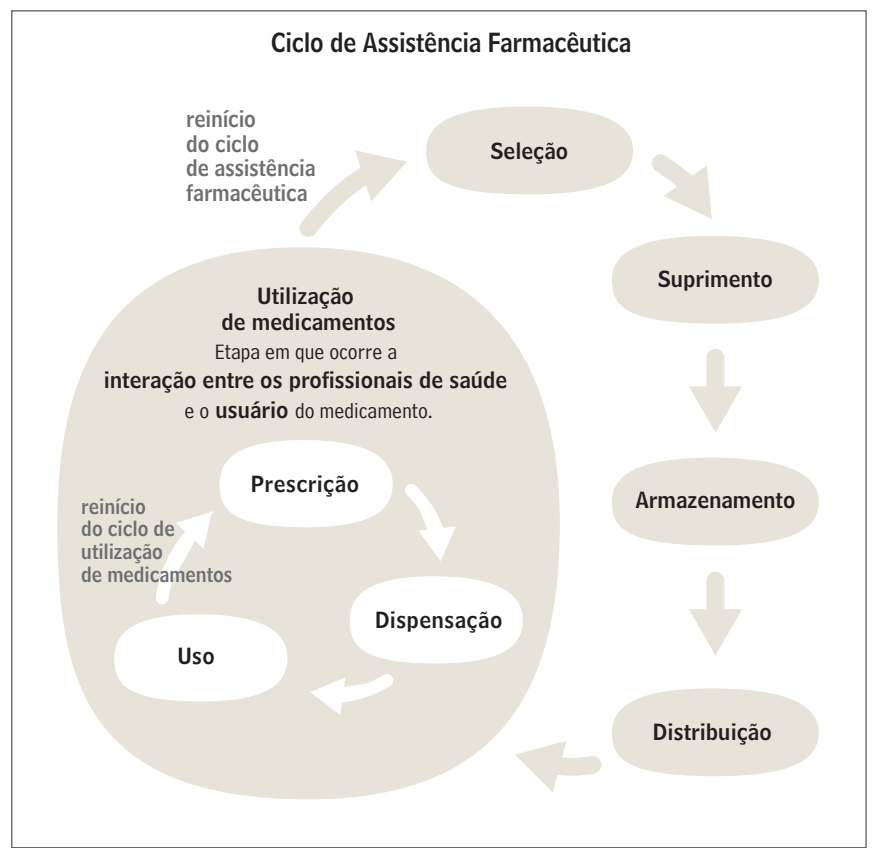

Figura 3: Ciclo de Utilização de Medicamentos no contexto da Assistência Farmacêutica A partir de Oliveira, Bermudez e Osório de Castro, 2007.

A seguir serão apesentadas cada uma das etapas do ciclo de utilização de medicamentos. 


\subsection{Prescrição}

Segundo a Política Nacional de Medicamentos (BRASIL, 1998), a prescrição, é o "ato de definir o medicamento a ser consumido pelo paciente, com a respectiva dosagem e duração do tratamento. Em geral, esse ato é expresso mediante a elaboração de uma receita médica".

A Organização Mundial de Saúde, em seu Guia para a Boa Prescrição Médica, afirma que o treinamento dado à maioria dos estudantes de medicina é "dedicado aos medicamentos", enfatizado suas indicações e efeitos colaterais. Entretanto, na prática clínica, ainda segundo a OMS, "é necessário adotar o enfoque contrário, partindo do diagnóstico em direção aos medicamentos", e ressalta o papel do paciente na etapa da prescrição:

[...]os pacientes variam de idade, sexo, porte físico e características socioculturais, fatores que podem, todos eles, influenciar a escolha do tratamento. Os pacientes, além disso, têm sua própria visão do que seja um tratamento adequado. Eles deveriam ser considerados parceiros plenos na definição de terapias. Tais fatos nem sempre são ensinados nas faculdades de Medicina. O número de horas gastas com terapêutica muitas vezes é baixo em comparação ao ensino tradicional de farmacologia. (OMS, 1998, p. 11)

$\mathrm{O}$ ato de prescrever medicamentos pode parecer simples, mas a prescrição racional exige um processo de análise complexo (OMS, 1998, p. 21), no qual se deve, em primeiro lugar, adotar um tratamento de escolha. (OMS, 1998, p. 18). Ou seja, em vez de avaliar, por exemplo, todos os medicamentos possíveis para a tosse seca a cada vez que precisa de um, o prescritor deve decidir antecipadamente, e com base na comparação da eficácia ${ }^{6}$, segurança, aplicabilidade e do custo de diferentes tratamentos para escolher seu tratamento individualizado - ou tratamento-I (OMS, 1998, p. 18).

Ainda segundo a OMS, uma vez feita esta escolha, o profissional passa ao processo de prescrição racional, que é composto de seis passos descritos abaixo, tendo-se ainda como exemplo o sintoma da tosse seca:

6 Utilidade e benefícios para o indivíduo ou comunidade decorrentes de serviço ou intervenção sob condições ideais. A determinação da eficácia é feita com base em ensaios clínicos controlados aleatórios. (Tradução livre do original: Last, 2001). Fonte: Descritores em ciências de Saúde - DesCS, In Biblioteca Virtual em Saúde - BVS. Disponível em: http://decs.bvs.br/ 
1. Definir o problema do paciente: Examinar, a partir dos sintomas descritos pelo paciente, as principais causas possíveis. No caso da tosse seca, a mais provável seria a membrana mucosa dos tubos brônquios, afetada por uma gripe, estar se irritando com facilidade. Mas há ainda a possibilidade de uma infeção bacteriana ${ }^{7}$ secundária $^{8}$ ou, mais improvável, um tumor no pulmão.

2. Especificar o objetivo terapêutico: interromper a irritação das membranas mucosas, que são a provável causa da tosse seca.

3. Verificar se o tratamento-I é adequado para o paciente em questão, ou seja, verificar se o tratamento-I é eficaz e seguro no caso apresentado. No exemplo dado, se o paciente é motorista de taxi, e o medicamento-I tem efeito sedativo, seria preferível procurar outro supressivo da tosse. No caso da tosse seca, como todos os medicamentos indicados têm efeito sedativo, pode ser melhor não prescrever nenhum medicamento, ou o de menor efeito sedativo, na menor dose, e por poucos dias.

4. Começar o tratamento. Nesta etapa, devem ser dados conselhos explicando a importância do tratamento. A explicação deve ser breve e ser dada com palavras compreensíveis ao paciente. A prescrição deve ser escrita da seguinte forma (no exemplo, a codeína foi o medicamento prescrito) codeína 15mg; 10 comprimidos; 1 comprimido 3 vezes ao dia; data; assinatura, nome, endereço. Enfatiza-se a necessidade de que o documento seja legível, indicando que se "Escreva com clareza!"

5. Fornecer informações, instruções e recomendações. Usado o exemplo da prescrição da codeína, o Guia afirma que o paciente deveria ser informado de que:

- A codeína suprimirá a tosse [indicação]; o medicamento começa a fazer efeito de 2 a 3 horas [tempo de ação do medicamento]; pode causar constipação [efeito adversos] e causará sono se a quantidade ingerida for

\footnotetext{
7 Infecções por bactérias, gerais ou inespecíficas. DesCS

Bactérias: Microorganismos causadores de infecções urinárias, pulmonares, do sistema nervoso, dos ossos etc. Geralmente são sensíveis aos antibióticos. Fonte: Dicionário Médico para o Público. Departamento de Moléstias Infecciosas. Hospital das Clínicas da Faculdade de Medicina da Universidade de São Paulo. Disponível em http://www.hcnet.usp.br/dicionario/departamento_m.htm.

3 Infecção secundária: infecção o corrida no lugar de uma infecção preexistente. Fonte: Merrian Webster Medline Plus. Disponível em: http://www.merriam-webster.com/medlineplus/secondary\%20infection
} 
excessiva [informação a respeito de sobredose] e se o paciente ingerir álcool [ingestão concomitante com outras substâncias].

- Recomende ao paciente que retorne, no caso da tosse não desaparecer, dentro de uma semana ou se efeitos colaterais indesejáveis surgirem [instrução para retorno]

— Finalmente recomende ao paciente que siga o roteiro de dosagem e que não tome bebidas alcoólicas [ênfase na importância do cumprimento da prescrição].

- Uma boa ideia é pedir que ele resuma, com suas próprias palavras, as informações principais para garantir que tudo foi entendido com clareza [promover feedback na comunicação] (OMS, 1998, p.21).

6. Monitorizar ou interromper o tratamento. Nesta etapa, o tratamento é avaliado segundo o retorno ou não do paciente à consulta agendada e, no caso do retorno do paciente, a solução ou não do problema inicialmente apresentado. O guia ressalta que, no caso de doenças crônicas, não há uma solução final para o problema e papel do médico consiste então em uma monitoração cuidadosa e um comprometimento maior do paciente em seguir o tratamento (OMS, 1998, p. 21). 
Segundo Osório-de-Castro e Pepe (2011) "a prescrição de medicamentos é um documento de valor legal, regida por regulamentações tanto sobre a prescrição quanto sobre aspectos éticos evolvidos". As autoras descrevem como deve ser a prescrição, segundo a regulamentação brasileira. Os dados apresentados pelas autoras foram categorizados, na presente pesquisa (tabela abaixo), a partir de 5 categorias - legibilidade; leiturabilidade ${ }^{9}$; elementos obrigatórios na prescrição médica; demais determinações a respeito da receita; e determinações a respeito das obrigações do prescritor. Observa-se que a característica de ser "clara", obrigatória na prescrição médica, foi classificada tanto como elemento tanto de legibilidade como de leiturabilidade, por poder ser atribuído tanto à legibilidade da letra (como tipografia simples e bem desenhadas, de tamanho adequado, e com bom contraste entre figura e fundo), como elemento de leiturabilidade (de fácil compreensão).

9 A classificação em elementos de legibilidade e leiturabilidade segue a sistematização realizada por Lima, 2007, para análise das bulas de medicamentos presentes no tratamento de pacientes cardíacos, que considerou elementos de legibilidade “os elementos relativos a tipografia e layout das bulas e de leiturabilidade os demais [elementos] que influenciem na facilidade ou interesse dos pacientes em lerem e compreenderem as bulas." 
1.Características relativas à legibilidade da prescrição médica (documento legal)

deve ser escrita sem rasura

deve ser escrita em letra de forma

deve ser clara

deve ser legível

deve ser escrita se utilizando tinta

2. Características relativas à leiturabilidade da prescrição médica (documento legal)

deve ser clara

deve ser legível

deve ser escrita em linguagem compreensível

3.Elementos obrigatórios na prescrição médica (documento legal)

nome do medicamento

forma farmacêutica

concentração do fármaco prescrito

quantidade total de medicamento

(número de comprimidos, drágeas, ampolas, envelopes), de acordo com a dose e duração do tratamento;

via de administração

intervalo entre as doses

dose máxima por dia

duração do tratamento

nome do prescritor

endereço do prescritor

de forma a possibilitar contato

telefone do prescritor

em caso de dúvidas ou ocorrência de problemas relacionados

ao uso de medicamentos prescritos;

assinatura do prescritor

carimbo do prescritor, onde deve constar o número de seu registro no respectivo conselho profissional

data da prescrição (as receitas de medicamentos sob controle especial têm validade de 15 (talidomida)

a 30 dias, a contar da data de emissão.

método de administração *(por exemplo, infusão contínua, injeção em uma única dose);

cuidados a serem observados na administração *

(por exemplo, necessidade de injetar lentamente ou de deglutir com líquido)

horários de administração *

(nos casos de possível interação alimentar ou farmacológica,

visando maior comodidade, adesão ou melhora do efeito terapêutico)

cuidados de conservação *

(por exemplo, a manutenção do frasco em geladeira)

4. Demais determinações - a respeito da informação contida na prescrição

a prescrição deve estar de acordo com nomenclatura e sistema de pesos e medidas oficiais

o medicamento deve ser prescrito pelo nome genérico, obrigatoriamente, adotando-se a Denominação Comum Brasileira

(DCB) e, em sua ausência, a Denominação Comum Internacional (DCI) * *

5.Demais determinações - a respeito das obrigações do prescritor

não indicar atos desnecessários ou proibidos pela legislação do País

não receitar de forma secreta ou ilegível ou laudos,

não atestar de forma secreta ou ilegível

não assinar em branco folhas de receituários

não assinar em branco laudos

não assinar em branco atestados ou outros documentos médicos

usar o receituário específico para prescrição de fármacos,

inclusive os que se encontram sob controle da autoridade reguladora

Tabela 2: Elaborada a partir das principais normas que versam sobre a prescrição, apresentadas por Osório de Castro e Pepe (2011). ${ }^{10} \quad *$ em alguns casos $\quad * *$ no ambiente do SUS

10 São elas: As Leis Federais 5.991/73 e 9.787/99, a Resolução 357/2001, do Conselho Federal de Farmácia e as Resoluções 1.552 (de 20/08/99), 1.477 (de 11/7/97) e 1.885 (de 23/10/08) do Conselho Federal de Medicina. (OSÓRIO DE CASTRO; PEPE, 2011) 
A comunicação na prescrição de medicamentos, portanto, não se inicia na consulta médica. Ela tem início no processo de aquisição de conhecimento pelo profissional de saúde prescritor seja na sua formação, documentos oficiais, informações produzidas pela indústria farmacêutica, livros-texto, informações trocadas entre profissionais ou disponibilizadas pelo computador (PEPE; OSÓRIO DE CASTRO p. 817-818).

Santana et al corroboram as autoras acima e lembram que as condições físicas do ambiente da prescrição influenciam no seu resultado:

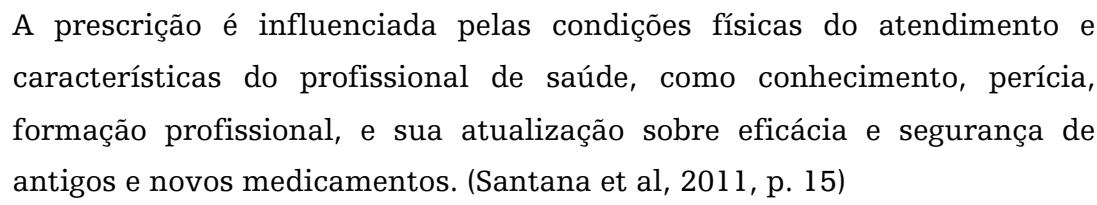

A prescrição é a etapa inicial da utilização de medicamentos, onde é definido o tratamento medicamentoso a ser seguido. Entretanto, pesquisas apontam que vem ocorrendo falhas nesta etapa que comprometem o uso racional de medicamentos, sendo indicada como responsável por mais de por mais de $50 \%$ das falhas no uso de medicamentos (KAWANO et al, 2006).

A comunicação entre médico e paciente é questão central na qualidade da prescrição de medicamentos. Portanto, falhas neste processo tem como consequência, o comprometimento do uso racional de medicamentos, seja pela inadequação do tratamento prescrito ao paciente, ou incompreensão do tratamento prescrito pelo paciente/acompanhante. (AKICI et al; 2004)

Às falhas na comunicação ao longo da consulta se somam problemas de falta de dados obrigatórios e legibilidade da receita médica (CRUCIOL-SUOZA; THOMSON; CASTITI, 2008, ARAÚJO; UCHOA, 2011), elemento fundamental de comunicação na utilização de medicamentos.

\subsection{Dispensação}

Segundo a Política Nacional de Medicamentos (BRASIL, 2008), na etapa da dispensação o paciente recebe o medicamento, assim como informações e orientações a respeito do seu tratamento com medicamentos: 
[dispensação] É o ato profissional farmacêutico de proporcionar um ou mais medicamentos a um paciente, geralmente como resposta à apresentação de uma receita elaborada por um profissional autorizado. Neste ato, o farmacêutico informa e orienta o paciente sobre o uso adequado do medicamento. São elementos importantes da orientação, entre outros, a ênfase no cumprimento da dosagem, a influência dos alimentos, a interação com outros medicamentos, o reconhecimento de reações adversas potenciais e as condições de conservação dos produtos. (Brasil, 1998 - Política Nacional de medicamentos)

Osorio de Castro e Pepe (2011) definem dispensação como o ato em que o farmacêutico informa e orienta o paciente sobre o uso e dispensação de medicamentos. É um ato farmacêutico no qual, além de proporcionar os medicamentos ao paciente, o farmacêutico informa e orienta o paciente sobre o uso adequado do medicamento.

Em pesquisa realizada a respeito desta etapa da assistência farmacêutica, Anacleto et al (2005) apresentam as seguintes categorias de falhas ocorridas:

falhas de comunicação, problemas relacionados à rotulagem e embalagem dos medicamentos, sobrecarga de trabalho e na estrutura da área de trabalho, distrações e interrupções, uso de fontes de informação incorretas e desatualizadas, e falta de conhecimento e educação do paciente sobre os medicamentos que utiliza (ANACLETO et al, 2005, p. 325).

\subsection{Uso}

O uso dos medicamentos, que representa a terceira e última etapa do ciclo de utilização de medicamentos, compreende a administração das doses, assim como os efeitos do tratamento. Este uso pode ser feito pelo profissional de saúde ou pelo paciente, quando este auto-administra as doses (OLIVEIRA; BERMUDES; OSÓRIO DE CASTRO, 2007).

No caso do tratamento ambulatorial — investigado na presente pesquisa é nesta etapa que o paciente / acompanhante auto-administra os medicamentos prescritos e dispensados longe do ambiente hospitalar. 
Nesta etapa, o paciente fará uso dos medicamentos, não só a partir das informações adquiridas ao longo das duas primeiras etapas, consequência tanto da comunicação verbal entre usuário e profissionais de saúde, como de elementos dispensados ao paciente. Esses elementos - como a receita médica, a bula, a embalagem onde o medicamento é acondicionado, e o próprio medicamento são igualmente meios de comunicação relativos ao tratamento.

Além de representar a etapa em que o paciente / acompanhante aplica, na prática do uso, o conhecimento adquirido ao longo das etapas anteriores, é também quando este adquire, pela observação do uso dos medicamentos e suas reações, conhecimentos particulares do seu tratamento, informações necessárias para o reinício do ciclo de utilização.

Estudos vêm evidenciando que o uso de medicamentos apresenta falhas que comprometem a eficácia do tratamento, podendo ainda gerar risco para o paciente (GANDHI et al, 2000).

A utilização de medicamentos é, portanto, um processo onde cada etapa influencia as demais. Quando cada etapa do uso ocorre correspondendo à sua função neste processo, conforme explicitam Osório de Castro e Pepe:

\begin{abstract}
A prescrição bem fundamentada em evidencias, atenta ao estado de saúde do paciente e às provas deste estado, e incorporando as orientações necessárias para o mesmo, aliada a seus sucedâneos, a dispensação orientada, a administração correta e o uso pelo paciente, orientado e acompanhado pelos profissionais de saúde, visa garantir o chamado uso racional de medicamentos. (OSÓRIO DE CASTRO; PEPPE, 2011)
\end{abstract}

\title{
3.4 Conclusão
}

A utilização de medicamento constitui um ciclo complexo no qual a comunicação desempenha papel central. Prescritores, dispensadores, e usuários, possuem experiências, vocabulário e expectativas distintas assim os papéis desempenhados por cada um deles neste ciclo. É relevante, portanto, que se aprimore o conhecimento a respeito desta relação complexa e crucial para a saúde e segurança do paciente. 


\section{Ergonomia e assistência em saúde}

O termo Ergonomia é composto pelas das palavras gregas ergon (trabalho) e nomos (leis) ${ }^{11}$ — é definido pelos Moraes e Soares (1989) ${ }^{12}$ como "como tecnologia projetual das comunicações entre máquina, trabalho e ambiente". Os autores explicam que a Ergonomia atua tanto como teoria tecnológica substantiva como operativa:

Como teoria tecnológica substantiva, a Ergonomia busca, através de pesquisas descritivas e experimentais sobre limiares limites e capacidades [...] fornecer bases racionais e empíricas para adaptar ao homem bens de consumo e de capital, meios e métodos de trabalho, no planejamento, programação e controle e processos de produção, sistemas de informação.

[...] Como tecnologia operativa, a Ergonomia objetiva, através da ação, resolver os problemas da relação entre o homem, equipamentos, ferramentas, comunicações e informações, solucionando os conflitos entre as inteligências natural e artificial. (MORAES; SOARES, 1989, p.20)

Há registros de considerações formais a respeito da relação entre as pessoas e seus ambientes de trabalho desde a Grécia antiga ${ }^{13}$. (WILSON, 2000, p. 558).

Moraes e Soares (1989) observam como os avanços tecnológicos demandaram o estudo formal da adaptação do trabalho ao homem:

Enquanto a produção se dava de modo artesanal, era possível obter formas úteis, funcionais e ergonômicas sem excessivos requisitos projetuais. A produção em série em larga escala, ou mesmo em pequena escala, impossibilita técnica e economicamente a compatibilização e adequação de produtos a partir do uso e adaptações sucessivas (MORES; SOARES, 1989, p.3).

11 Laville (1977, p. 1) acredita que a etimologia o termo não especifica bem o objeto dessa disciplina, que ele define como sendo "o conjunto de conhecimentos a respeito do desempenho do homem em atividade, a fim de aplicá-los a concepção das tarefas, dos instrumentos, das maquinas e- dos sistemas de produção".

12 Esta definição foi apresentada após os autores analisarem a definição do conceito do campo de atuação da Ergonomia a partir das definições de 22 diferentes autores, e com o propósito de englobar os aspectos e objetivos apresentados; assim conceituam Ergonomia. (MORAES; SOARES, 1989 p. 8 - 19).

13 Wilson (2000, p. 558) lembra que a consideração da relação entre o homem e seu ambiente de trabalho é observada em registros médicos medievais e em trabalhos poloneses e alemães do fim do século XIX. 
Ergonomia como disciplina se inicia a partir da Segunda Guerra Mundial, na Inglaterra (PHEASANT, 1991, p.3). Isso se deu pela necessidade de adaptar-se ao homem os equipamentos novos e complexos produzidos para a segunda guerra mundial, que não funcionavam conforme o que se necessitava delas (WILSON, 2000, p. 558).

O campo da Ergonomia é denominado por uma multiplicididade de termos $^{14}$. Wilson (2000) considera que a multiplicidade de termos é prejudicial ao campo e defende o uso do termo Ergonomia. Apesar de considerar que a nomenclatura Ergonomia apresenta algumas desvantagens se comparada a Fatores Humanos - como a falta de significado implícito - ele considera que seria prejudicial a perda dos nomes derivados, como ergonomista para o profissional da área. Moraes e Mont'Alvão (2009) consideram que já existe uma tendência para o uso do termo Ergonomia $^{15}$, que foi incorporado ao nome da Associação Americana de Ergonomia — que passou em 1992 a se chamar Human Factors and Ergonomics Society.

\subsection{Ergonomia: áreas de especialização}

Segundo a Associação internacional de Ergonomia, (IEA - International Ergonomics Association) o campo de atuação da Ergonomia pode ser dividido em três grandes subáreas, chamadas de campos de especialização. São eles: Ergonomia Física - com foco na anatomia humana, Ergonomia Cognitiva com foco nos processos mentais, e Ergonomia Organizacional - com foco na otimização dos sistemas sociotécnicos. A tabela a seguir, elaborada a partir da categorização do IEA, apresenta os campos de especialização, seu foco, e tópicos relevantes. Vale ressaltar que as áreas de atuação não se excluem mutuamente e estão em constante evolução. (IEA, 2000)

14 Fatores humanos, engenharia humana, engenharia dos fatores humanos, ergonomia, engenharia da performance humana, ergonomia aplicada, , engenharia da performance humana, ergonomia industrial, psicologia experimental aplicada e psicologia dos fatores humanos são alguns dos termos identificados por Licht, Polzella e Boff, em pesquisa a respeito da multiplicidade de denominações do campo. (LICH; POLZELLA; BOFF, 1990, p. 4). 


\begin{tabular}{|c|c|c|}
\hline & foco & tópicos relevantes \\
\hline 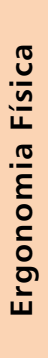 & $\begin{array}{l}\text { - anatomia humana, } \\
\text { - antropometria, } \\
\text { - características fisiológicas e } \\
\text { biomecânicas que se relacionam com a } \\
\text { atividade física. }\end{array}$ & $\begin{array}{l}\text { - posturas de trabalho } \\
\text { - manuseio de materiais } \\
\text { - movimentos repetitivos } \\
\text { - distúrbios musculoesqueléticos } \\
\text { relacionados ao trabalho, } \\
\text { - layout de ambiente de trabalho } \\
\text { - segurança e saúde. }\end{array}$ \\
\hline 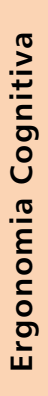 & $\begin{array}{l}\text { - processos mentais, tais como: } \\
\text { percepção, memória, raciocínio e } \\
\text { resposta motora, e em como eles afetam } \\
\text { as interações entre seres humanos e } \\
\text { outros elementos de um sistema. }\end{array}$ & $\begin{array}{l}\text { - carga mental de trabalho } \\
\text { - tomada de decisão } \\
\text { - desempenho especializado } \\
\text { - interação humano-computador } \\
\text { - confiabilidade humana } \\
\text { - estresse do trabalho e do treinamento } \\
\text { e como esses fatores se relacionam como } \\
\text { a configuração homem-sistema }\end{array}$ \\
\hline 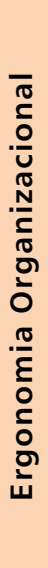 & $\begin{array}{l}\text { - otimização dos sistemas } \\
\text { sociotécnicos, incluindo suas estruturas } \\
\text { organizacionais, políticas e processos. }\end{array}$ & $\begin{array}{l}\text { - comunicação } \\
\text { - planejamento, gestão e recursos de } \\
\text { equipe e do trabalho } \\
\text { - projeto participativo } \\
\text { - ergonomia comunitária } \\
\text { - trabalho cooperativo } \\
\text { - novos paradigmas de trabalho } \\
\text { - cultura organizacional } \\
\text { - organizações virtuais } \\
\text { - teletrabalho } \\
\text { - gestão da qualidade }\end{array}$ \\
\hline
\end{tabular}

Tabela 3: Campos de Especialização da Ergonomia.

Tabela elaborada a partir doas definições apresentadas pela Associação internacional de Ergonomia. Fonte: IEA, 2000.

\subsection{Ergonomia na assistência em saúde e segurança do paciente}

Para a Organização Mundial de Saúde, a contribuição de Ergonomia para o atendimento em saúde ainda é pequeno se comparado a outros segmentos, onde a segurança representa fator crucial (OMS, 2009, p.6). 
No seu relatório a respeito de Ergonomia e segurança do paciente, Human Factors in Patient Safety: Review of topics and tools, a Organização Mundial de Saúde - , lembra que as forças armadas e a aviação são os setores que há mais tempo utilizam princípios ergonômicos para melhorar seus equipamentos, ambiente de trabalho e desempenho humano. O documento, no entretanto, afirma que, atualmente, muitos setores têm equipes de especialistas para cuidar de aspectos ergonômicos. Ainda segundo a OMS, o primeiro grupo clínico de fatores humanos, o Clinical Human Factors Group - CHFG, foi fundado somente em 2007, pelo piloto Martin Bromiley, que perdeu sua esposa devido a um incidente anestésico, com causa em fatores humanos (OMS, 2009, p.6). Bromiley, proveniente da indústria da aviação, que tradicionalmente incorpora a abordagem ergonômica em todos os aspectos relativos à segurança, ficou surpreso da pouca atenção dada à ergonomia na segurança ao paciente.

A CHFG considera que um sistema de saúde que leve em conta a ergonomia no cerne da melhoria clínica, administrativa e organizacional conduz a melhorias significativas em segurança e eficiência (CHFG, 2012).

Lucian Leape, professor de política de saúde no Departamento de Política de Saúde na Escola de Saúde Pública de Harvard e membro da equipe do Comitê em Qualidade no Atendimento em Saúde nos Estados Unidos da América - Committee on Quality of Health Care in America ${ }^{16}$ publicou, no ano de 2004, um artigo na revista Ergonomics in Design. No artigo, Leape inicialmente apresenta o prejuízo causado pelos erros no atendimento médico, e expõe tanto os motivos para que os erros ocorram como para que eles se perpetuem. Em seguida, afirma que, devido à complexidade do atendimento à saúde e às enormes dificuldades encontradas, a participação da Ergonomia é de grande relevância, e pede a participação dos ergonomistas na reconstrução do sistema de saúde, desta vez considerando-se os aspectos ergonômicos:

(...) o atendimento em saúde precisa desesperadamente do seu envolvimento e da expertise para aprender como destrinchar nossos complexos sistemas, reestruturá-los usando princípios de fatores humanos para fazer com que eles funcionem. (Leape, 2004. p.11)

16 Leape fez parte de equipe que publicou os documentos To err is human: building a safer health system, e Crossing the quality chasm: A new health system for the 21th Century, cujas conclusões são a base para a construção do modelo de atendimento em doenças crônicas, desenvolvido por Wagner et al. 
Pascale Carayon (2012) corrobora a posição de Leape com relação à relevância da ergonomia na melhoria do sistema de saúde. Segundo ela, a Ergonomia contribui para o aumento da segurança nos sistemas de saúde ao considerar as várias necessidades, habilidades e limitações das pessoas envolvidas nesses sistemas.

Carayon (2012) apresenta, a partir das três áreas de especialização apresentadas pela IEA, contribuições relevantes de todas as áreas da ergonomia para o atendimento em saúde e segurança do paciente. A tabela abaixo mostra, nas áreas conforme apresentadas pela IEA, exemplos de problemas ergonômicos abordados em cada uma delas, no atendimento em saúde e segurança do paciente.

\begin{tabular}{|c|c|}
\hline $\begin{array}{l}\text { Ergonomia } \\
\text { física }\end{array}$ & $\begin{array}{l}\text { - projeto de dependências hospitalares } \\
\text { - projeto de ambiente físico } \\
\text { - manejo de paciente } \\
\text { - projeto de quarto de hospital } \\
\text { - ruídos } \\
\text { - alarmes } \\
\text { - ambientes de terapia intensiva } \\
\text { - instalações de atendimento de emergência }\end{array}$ \\
\hline $\begin{array}{l}\text { Ergonomia } \\
\text { cognitiva }\end{array}$ & $\begin{array}{l}\text { - erro humano associado a cognição } \\
\text { - usabilidade de equipamentos médicos }\end{array}$ \\
\hline $\begin{array}{l}\text { Ergonomia } \\
\text { organizacional }\end{array}$ & $\begin{array}{l}\text { - estresse relacionado ao trabalho na assistência em saúde } \\
\text { - síndrome de burnout em trabalhadores da assistência em } \\
\text { saúde } \\
\text { - cultura e aprendizagem organizacional } \\
\text { - trabalho em equipe } \\
\text { - escalas de trabalho } \\
\text { - design organizacional } \\
\text { - questões relacionadas às famílias como uma organização } \\
\text { complexa, com papéis e responsabilidades desempenhadas a } \\
\text { respeito da administração de informação }\end{array}$ \\
\hline
\end{tabular}

Tabela 4: Exemplos da contribuição das diferentes áreas de especialização da ergonomia na assistência em saúde e segurança de paciente. Fonte: Carayon, 2012. 
Conforme apresentado pela IEA — International Ergonomics Association (2012), as áreas de especialização não são isoladas umas das outras nem se excluem mutuamente. Carayon (2012) chama a atenção para o caráter colaborativo da assistência em saúde e ressalta a importância de se observar o tecido social do sistema de trabalho. A autora usa como exemplo o projeto de um ambiente físico de um hospital, em que é necessário se considerar, não só requisitos físicos dos pacientes, enfermeiras, médicos e demais usuários, mas também necessidades como a comunicação, o trabalho em equipe e a interação social.

Vincent et al. (2004, p.476) afirmam que a abordagem ergonômica é atualmente aplicada em muitos aspectos do atendimento em saúde, e lembram importantes avanços na anestesia, feitos através de monitoramento e análise de incidentes, cuidado nos aspectos ergonômicos do design de equipamentos e implementação de equipamentos de segurança e atenção à fadiga e sobrecarga cognitiva, entre outras contribuições da ergonomia à área de atenção à saúde.

Entre os anos de 2000 e 2010, houve um expressivo aumento de interesse, dentro do campo da ergonomia pelo tema da segurança do paciente (CARAYON; BUCKLE, 2010, p.643).

No ano de 2010, a Revista Applied Ergonomics dedicou uma edição especial à segurança do paciente. Ao apresentar os artigos, Carayon e Buckle (2010, p.643-644) afirmam que as evidências demonstram que a Ergonomia tem potencial para aumentar não só a segurança do paciente, como também a eficácia e efetividade do sistema de saúde, assim como o bem-estar da equipe de atendimento em saúde.

A diversidade das abordagens dos artigos serve de exemplo tanto da complexidade do sistema de saúde e, portanto, dos problemas a serem enfrentados pela Ergonomia, como também dos recursos disponíveis no campo para a abordagem desses problemas.

Como exemplo da complexidade do sistema de saúde e consequente diversidade de tópicos abordados pela ergonomia, podemos citar alguns artigos apresentados na edição especial do periódico Applied Ergonomics (2010).

- Karsh e Brown (2010), por exemplo, pesquisam a segurança do paciente a partir de uma abordagem macroergonomia. 
- Carayon (2010), por sua vez, analisa a ergonomia aplicada à segurança do paciente a partir do modelo de inovação de Greenhalgh et al (2004) para identificar os fatores que podem dificultar ou facilitar a disseminação das inovações da ergonomia nas instituições de saúde.

- Wears et al (2010), utilizam os estudos realizados pelo campo da ergonomia em ambientes perigosos, para aplicar esse conhecimento ao ambiente hospitalar de atendimento de emergência.

- Wiegmann et al (2010) a partir da observação do impacto erros em cirurgias representam para a segurança do paciente, realizam uma revisão integrada do ambiente da sala de cirurgia, uma vez que este ambiente tem impacto direto no processo do atendimento cirúrgico.

- Hignett e Lu estudam o espaço de atendimento para tratamento de pacientes hospitalizados, tendo como base para esta abordagem, a área da cama em instalações hospitalares, médicas e cirúrgicas. Esta escolha se dá pelo fato desta área ser elemento que pode apresentar riscos para a segurança do paciente - como quedas, ruídos e transmissão de infecção. O estudo conclui que a área da cama para atendimento de pacientes hospitalizados, no Reino Unido, é inferior ao indicado para os hospitais do Reino Unido.

- Karsh e Brown realizam, a partir da macroergonomia, uma avalição do impacto de como diferentes níveis do sistema de atendimento em saúde por exemplo, profissional de saúde, ou organização de saúde — interagem e impactam na segurança do paciente.

- Schell (2010) estuda o aprimoramento do texto no reconhecimento do nome de medicamentos com o objetivo de minimizar os erros de medicação.

- E Buckle et al realizam uma avalição dos erros de medicação no atendimento em saúde, tanto no ambiente hospitalar como ambulatorial, quando o uso de medicamentos é feito pelo paciente fora do ambiente hospitalar. Os autores utilizam o método de Workshops de mapeamento de sistema - System mapping workshops, sendo os participantes 37 profissionais de saúde, para identificação dos problemas a respeito do típico estudado.

No Brasil, a ergonomia igualmente vem atuando no campo da segurança do atendimento em saúde, como exemplificam os estudos abaixo: 
- Diniz (2006), realizou avalição das posturas adotadas nas enfermarias da Clínica Cirúrgica de um hospital em São Luís, MA.

- Marziale e Carvalho (1998) Analisaram as condições ergonômicas do trabalho da equipe de enfermagem em unidade de internação de cardiologia

- Raposo (2007), em sua pesquisa de Mestrado intitulada No coração do hospital, realizou investigação ergonômica nas centrais de materiais esterilizados nas unidades públicas de saúde, observando falhas nesta instalação hospitalar, cuja relevância é crucial para segurança hospitalar.

\subsection{Conclusão}

A Ergonomia vem contribuindo para a área do atendimento à saúde, através da pesquisa em suas diferentes áreas de especialização. Entretanto as pesquisas realizadas focam no atendimento secundário e terciário ainda que a atenção primária em saúde seja um dos componentes mais complexos do sistema de saúde (Beasley, Escoto e Karsh, 2007, p.921). Portanto, é relevante, que se desenvolva pesquisa nesta etapa do atendimento em saúde, fundamental para a manutenção da saúde dos pacientes crônicos. 


\section{Modelagem da comunicação}

A comunicação é um fenômeno complexo, tão complexo quanto a própria sociedade (KRISTEVA, 1969; NARULA, 2006) ${ }^{17}$.

Este fenômeno, que tem a interação como principal característica, é considerado indissociável da própria estrutura social. Menezes (1978) explica que a complexidade da comunicação, segundo o autor, "tão complexa como o próprio comportamento humano", representa dificuldade para o seu estudo. O autor lembra ainda outros dois fatores com que se deparam pesquisadores que pretendem estudar a comunicação: seu aspecto dinâmico ou, nas palavras do autor, "porque comunicação é por natureza um 'processo', e não uma 'coisa"” e ainda "porque consiste num fenômeno multidimensional que se manifesta em diferentes níveis da realidade e que acarreta diversidade dos tipos de análise" (MENEZES,1978, p. 151).

Segundo Rabaça e Barbosa, o termo comunicação deriva do latim communicare, cujo significado seria tornar comum, partilhar, repartir, associar, trocar opiniões, conferenciar", portanto, ainda segundo os autores, "comunicar implica em participação [...], em interação, em troca de mensagens, em emissão e recebimento de informações novas" (RABAÇA; BARBOSA, 1978, p. 106-107).

Narula (2006) esclarece que comunicação não se restringe à comunicação oral, mas a todo contato compartilhado por seres humanos e dá alguns exemplos de formas não verbais de comunicação:

\footnotetext{
As mensagens no ambiente compartilhado podem ser não só verbais, não verbais, visuais ou olfativas, mas também podem ser leis, costumes, práticas, maneiras de se vestir, gestos construções bandeiras, exposições, etc. (NARULA, 2006, p3, tradução nossa),
}

\footnotetext{
17 Kristeva (1969, p.18) afirma que não há sociedade sem linguagem, como não há sociedade sem comunicação" Segundo Narula (2006, p.3) “Comunicação é um processo social, e incontáveis maneiras em que os seres humanos estão em contato com os outros.
} 
Segundo Monmollin, Ergonomia é tecnologia das comunicações nos sistemas homem-máquina". Trata-se portanto, da tecnologia das interações vivenciadas pelo homem, conforme explica o autor:

\footnotetext{
A ergonomia é uma tecnologia das comunicações dos sistemas homensmáquinas. Mais exatamente, é uma tecnologia das comunicações entre os homens e as máquinas, se conferirmos a estas um sentido muito amplo: máquinas ferramentas, diversos acessórios, instruções, entregas, registros e, para cada homem, os demais homens do sistema. (MONTMOLLIN, 1971, p. 3, tradução nossa, grifo do autor)
}

Montmollin esclarece que um sistema é "um conjunto de variáveis interdependentes" a partir de uma finalidade. Há, então, tantos sistemas quanto finalidades. Se atendo aos sistemas homens-máquinas, portanto, Ergonomia se atém a um conjunto - determinado a partir de sua finalidade — de variáveis interdependentes, "onde pelo menos um dos elementos é um homem".

\subsection{Modelagem da comunicação}

Montmollin define modelo como "um conjunto de elementos que reproduz outro conjunto de elementos mais rico, considerando-se este último como norma que se compara ao modelo. À norma, normalmente se dá o nome de 'realidade' “. (MONTMOLLIN, 1971, p.30). 


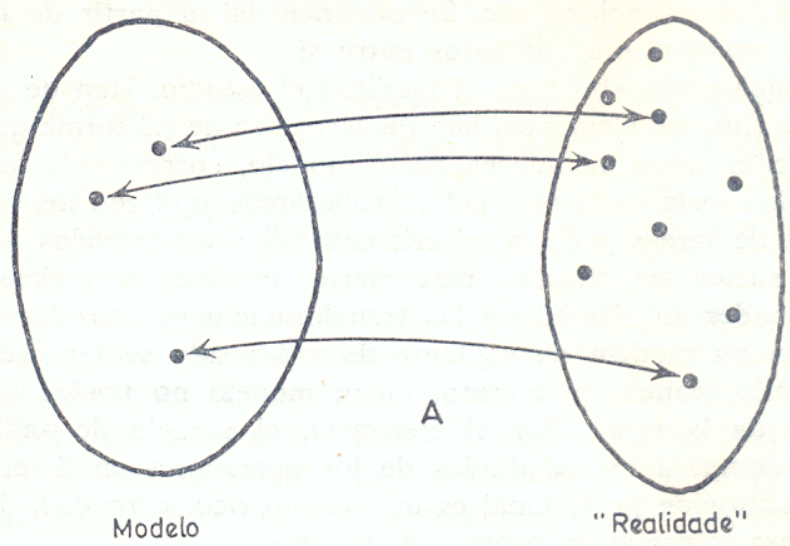

Figura 4: Ilustração do modelo segundo Montmollin: um conjunto de elementos que reproduz um conjunto mais rico. Fonte: Montmollin, 1971, p. 21, tradução nossa.

Segundo Narula "a complexidade e mudança constante no processo de comunicação torna imperativo que esta seja apresentado de forma simples e generalizada, para que se entenda a estrutura e funções da comunicação" (NARULA, p. 10, tradução nossa). Segundo Narula, "um modelo é uma representação de um fenômeno real em termos abstratos de forma que este possa ser aplicado de formas diferentes em diferentes momentos" (2006, p. 9, tradução nossa).

Os modelos de comunicação, sendo a visualização do processo de informação (Narula 2006, p. 23), apresentam a base do processo da comunicação, assim como a sua interação, possibilitando, assim, sua aplicação.

Os modelos de comunicação podem ser apresentados em três classificações: linear, relacional e de convergência. (Moraes, 2002 e Narula, 2006). Na tabela abaixo, elaborada por Narula (2006), tem-se uma sistematização dos modelos apresentados, a partir de sua publicação, autores, componentes principais, e uma breve definição de comunicação considerada pela sistematização realizada.

\begin{tabular}{|l|l|l|l|}
\hline \multicolumn{1}{|c|}{ fontes } & tipo de modelo & $\begin{array}{c}\text { componentes } \\
\text { principais } \\
\text { do modelo }\end{array}$ & \multicolumn{1}{|c|}{$\begin{array}{c}\text { definição } \\
\text { de comunicação }\end{array}$} \\
\hline & & - fonte & \\
Claude Shannon e & Linear & - codificador & Todos os processos \\
Warren Weaver & & - decodificador & $\begin{array}{l}\text { nos quais uma } \\
\text { mente afeta a outra. }\end{array}$ \\
& & - receptor & \\
& & - destino & \\
\hline
\end{tabular}




\begin{tabular}{|c|c|c|c|}
\hline fontes & tipo de modelo & $\begin{array}{c}\text { componentes } \\
\text { principais } \\
\text { do modelo }\end{array}$ & $\begin{array}{c}\text { definição } \\
\text { de comunicação }\end{array}$ \\
\hline $\begin{array}{l}\text { Wilbur Schramm } \\
\text { (1973) }\end{array}$ & Relacional & $\begin{array}{ll}- & \text { signos } \\
\text { informacionais } \\
-\quad & \text { relação entre } \\
& \text { participantes } \\
-\quad & \text { receptores } \\
& \text { ativos }\end{array}$ & $\begin{array}{l}\text { Um conjunto de } \\
\text { atos de } \\
\text { comunicação } \\
\text { focados em um } \\
\text { conjunto de signos } \\
\text { informacionais em } \\
\text { uma relação } \\
\text { especifica. }\end{array}$ \\
\hline $\begin{array}{l}\text { D. Lawrence Kincaid } \\
\text { (1979) }\end{array}$ & Convergência & $\begin{array}{ll}- & \text { incerteza } \\
& \text { na informação } \\
- & \text { convergência } \\
- & \text { mútuo } \\
& \text { entendimento } \\
- & \text { mútua } \\
& \text { concordância } \\
- & \text { ação coletiva } \\
- & \text { rede de } \\
& \text { relacionamento }\end{array}$ & $\begin{array}{l}\text { Um processo de } \\
\text { convergência no } \\
\text { qual a informação é } \\
\text { compartilhada pelos } \\
\text { participantes de } \\
\text { forma a se alcançar } \\
\text { o entendimento } \\
\text { mútuo. }\end{array}$ \\
\hline
\end{tabular}

Tabela 5: Resumo dos Modelos de Comunicação Fonte: Narula, 2006, p. 22, tradução nossa

A seguir serão apresentados os Modelos de Shannon e Weaver, Wilbur Schramm e Kincaid

\subsubsection{O modelo de Shannon e Weaver}

Moraes (2002, P. 7), afirma que a Ergonomia, nas suas origens, utiliza o Modelo de Shannon e Weaver para explicitar as interfaces entre homens e máquinas. 
O modelo, publicado em 1949 pelo matemático Claude E. Shannon (SHANNON; WEAVER, 1949, 1988), foi criado para analisar a informação no que diz respeito ao seu aspecto técnico ${ }^{18}$, ou seja, à precisão da transferência do emissor para o receptor, de um conjunto de símbolos (discurso escrito) ou um sinal continuamente variável (transmissão de música ou voz pelo rádio ou telefone).

Weaver explica que, no modelo proposto por Shannon, o conceito de informação diz respeito somente aos aspectos técnicos e que o conceito de ruído proposto por Shannon não diz respeito aos aspectos semânticos ou de efetividade da comunicação.

A palavra informação, nesta teoria [Matemática da Comunicação] é usada num sentido especial que não pode ser confundido com seu sentido corriqueiro. Em particular, informação não pode ser confundida com significado.

De fato, duas mensagens, uma muito carregada de significado e outra que é somente nonsense, podem ser, pelo presente ponto de vista, exatamente equivalentes no que diz respeito à informação. Sem dúvida é isso que Shannon quer dizer quando diz que 'o aspecto semântico da comunicação é irrelevante para os aspectos de engenharia'. (WEAVER, , 1949,1998, p. 8, tradução nossa)

Weaver, que apresenta o modelo no capítulo inicial do livro, o descreve da seguinte maneira:

A fonte de informação seleciona, a partir de uma série de mensagens possíveis, uma mensagem desejada. A mensagem desejada pode consistir em palavras escritas ou faladas, ou figuras, música, etc. O transmissor modifica esta mensagem em um sinal que vai realmente ser enviado pelo canal de comunicação do transmissor ao receptor. (WEAVER, 1949,1998, tradução nossa)

18 Weaver (1998), categoriza os problemas de comunicação em três níveis:

Nível A. Os problemas técnicos, que dizem respeito à precisão da transferência do emissor para o receptor, do conjunto de símbolos (discurso escrito), ou um sinal continuamente variável (transmissão de música ou voz pelo rádio ou telefone), ou um sinal continuamente variável bidimensional (televisão).

Nível B. O problema semântico, que diz respeito ao nível de precisão com que os símbolos transmitidos comunicam o significado desejado. Este tipo de problema diz respeito a uma aproximação satisfatoriamente próxima entre o significado desejado pelo remetente e o significado interpretado pelo receptor.

Nível C. O problema da efetividade, diz respeito ao sucesso com que o significado transmitido leva à conduta desejada de receptor. A respeito desta afirmação, o autor afirma que, apesar de parecer, à primeira vista, restrito dizer que o objetivo de toda a comunicação é influenciar a conduta do destinatário, se abrimos o significado de conduta para um conceito relativamente amplo, podemos deduzir que, ou a comunicação afeta a conduta, ou não teria nenhum efeito discernível ou provável. 
Segundo Rabaça e Barbosa (1978, p.109), o modelo de Shannon e Weaver preocupa-se sobretudo com a possibilidade de utilizarem-se os meios ou canais disponíveis com a maior eficiência possível, conseguindo-se um máximo de informação e um mínimo de ruídos.

Ruído é definido por Weaver como acréscimos não desejados ao sinal, que podem ser: “distorções do som, (em telefonia, por exemplo) ou estática (no radio), na forma ou nuança da figura (televisão), ou erros de transmissão (telégrafo ou faximile), etc. Todas essas mudanças no sinal transmitido são chamados ruídos." (WEAVER, 1949,1998, p. 7-8)

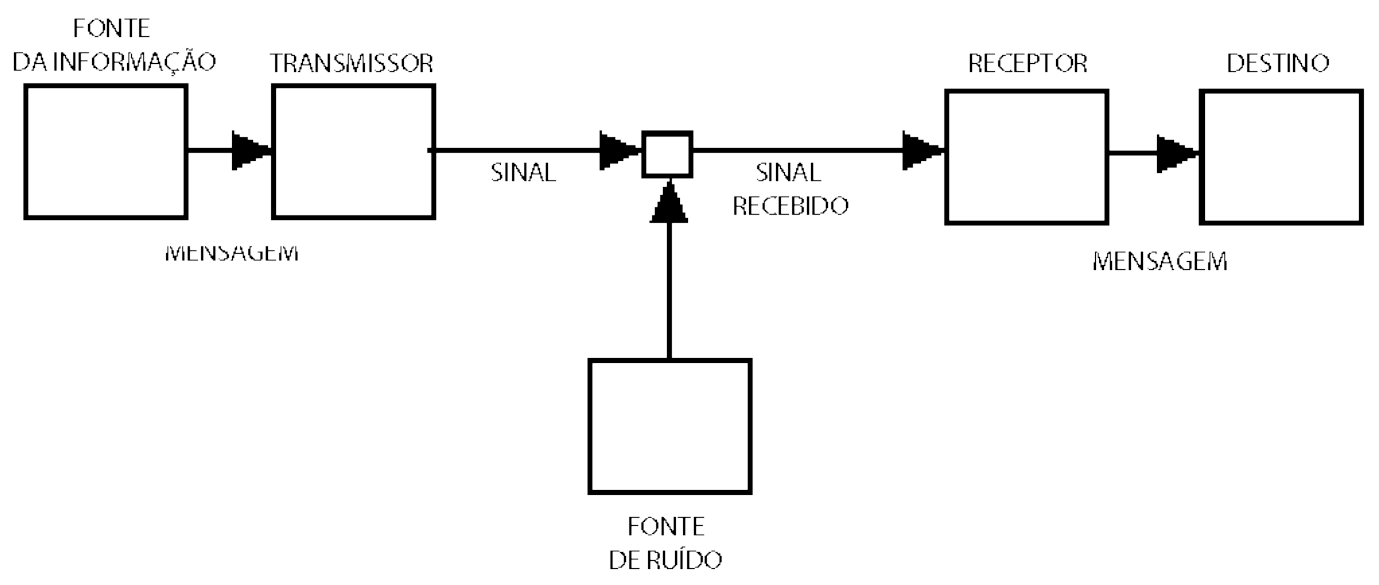

Figura 5: Representação simbólica do sistema de comunicação (Fonte: SHANNON \& WEAVER, 1949,1998, p.7, tradução nossa)

Embora voltado especialmente para a comunicação eletrônica, o modelo de Shannon e Weaver foi complementado e aplicado de diversas formas na teoria da comunicação, conforme previa Weaver:

\footnotetext{
Esta é uma teoria tão genérica que não é necessário se dizer que tipos de símbolos estão sendo considerados - se letras ou palavras escritas, ou notas musicais, ou palavras faladas, ou musica sinfônica, ou imagens. A teoria é tão profunda que a relação revelada por ela se aplica a todas essas e outras formas de comunicação. (WEAVER, 1949 p. 25, tradução nossa).
}

Weaver observou que a análise dos níveis semântico e de efetividade da comunicação seriam adições necessárias ao diagrama esquemático apresentado. 
Entretanto, ele acreditava que seriam necessárias apenas "adições de pouca significação". O autor indica as adições necessárias, como a incorporação dos conceitos "ruído de engenharia do sistema" - que seria mais abrangente que o termo "ruído", incluindo as questões semânticas - e "receptor semântico". Weaver afirma que também a decodificação semântica deve ser levada em consideração, incluindo aí características culturais no destinatário nas suas observações.

\subsubsection{Schramm: destinatário e fonte devem estar sintonizados}

O modelo proposto por Schramm é um desenvolvimento do de Shannon e Weaver, segundo o qual a comunicação sempre requer, pelo menos, três elementos $-\mathrm{a}$ fonte, a mensagem e o destinatário. ${ }^{19}$

Segundo o modelo de Schramm, uma fonte pode ser um indivíduo (fala, escrita, desenhos, gesto) uma empresa de comunicação (como um jornal, uma editora, uma estação de televisão, um estúdio de cinema). A mensagem pode ser em forma de tinta no papel, ondas sonoras no ar, impulsos em uma corrente elétrica, um aceno com a mão, uma bandeira no ar ou qualquer outro sinal capaz de ser interpretado com significado. O destinatário pode ser um indivíduo ouvindo, assistindo, ou lendo; ou um membro de um grupo, como um grupo de discussão, a plateia, uma torcida de futebol, ou uma multidão, ou um membro individual de um grupo particular que nós chamamos de audiência de massa, como o leitor de um jornal ou um telespectador. (SHRAMM, 1961, p3)

Segundo Shramm, talvez o mais importante do sistema de comunicação apresentado seja o fato do receptor e da fonte deverem estar sintonizados. Diferente do modelo de Shannon e Weaver, o elemento semântico é considerado, e a sintonia considera não só a identificação dos sons como também seu significado.

19 Optou-se pela tradução "destinatário", em vez de receptor, pelo termo originalmente usado por Schramm "destination" ser diferente do usado por Shannon e Weaver, "receiver". 
O modelo abaixo, apresentado por Schramm apresenta os diferentes campos de experiência das pessoas envolvidas no processo de comunicação, indicando que há sinal quando os campos de experiência apresentam características comuns.

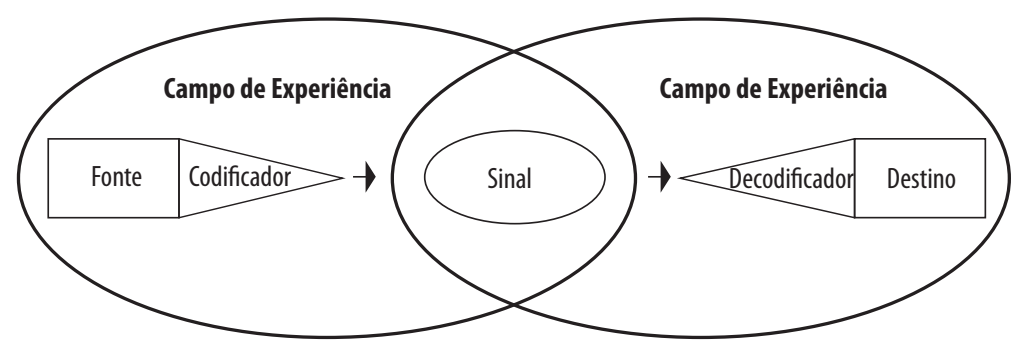

Figura 6: Representação gráfica do processo de comunicação, que ocorre onde há interseção dos campos de experiência do emissor e destinatário. Fonte: Schramm, 1961, p6, tradução nossa.

O autor explica que as ovais representam a "experiência acumulada de dois indivíduos tentando se comunicar". O autor explica que o processo de codificação e decodificação só se realiza a partir desta experiência, e cita como exemplo a nossa incapacidade de codificar ou decodificar mensagens em uma língua que não conhecemos. Isto seria impossível, por esta língua não fazer parte do nosso “campo de experiência". Também objetos são, segundo o autor, decodificados segundo nosso conhecimento prévio, ou seja, nosso campo de experiência.

Ainda segundo o modelo de Shannon, a comunicação se dará mais facilmente quanto mais houver área de encontro entre as ovais do sistema apresentado acima, ou seja, quanto mais comum for o campo de experiência entre as pessoas tentando se comunicar. (Schramm, 1961, p.6).

A fonte, portanto, tenta codificar a mensagem de tal forma que facilite para o receptor estabelecer a sintonia. Ou seja, relacionar esta a partes da sua experiência que são mais comuns com as da fonte, a fim de facilitar o processo de comunicação.

Além do campo de experiência, outros dois elementos apresentados por Schramm a serem considerados na sistematização da comunicação: o feedback e a multiplicidade de canais. 
Segundo Schramm (1961) estamos constantemente decodificando signos do ambiente, interpretando esses signos e codificando alguma coisa como resultado. De fato é errôneo pensar no processo de comunicação começando e acabando em algum lugar. Na verdade ele não tem fim. Nós somos um pouco como centrais telefônicas, manejando e reencaminhando a grande corrente sem fim da comunicação. Nós podemos precisamente pensar na comunicação como passando por nós - certamente transformada pelas nossas interpretações, nossos hábitos nossas habilidades e capacidades, mas a entrada ainda sendo refletida na saída.

Schramm introduz então um novo elemento ao processo de comunicação, o feedback. No diagrama abaixo a representação gráfica de duas pessoas se comunicando, considerando-se o feedback:

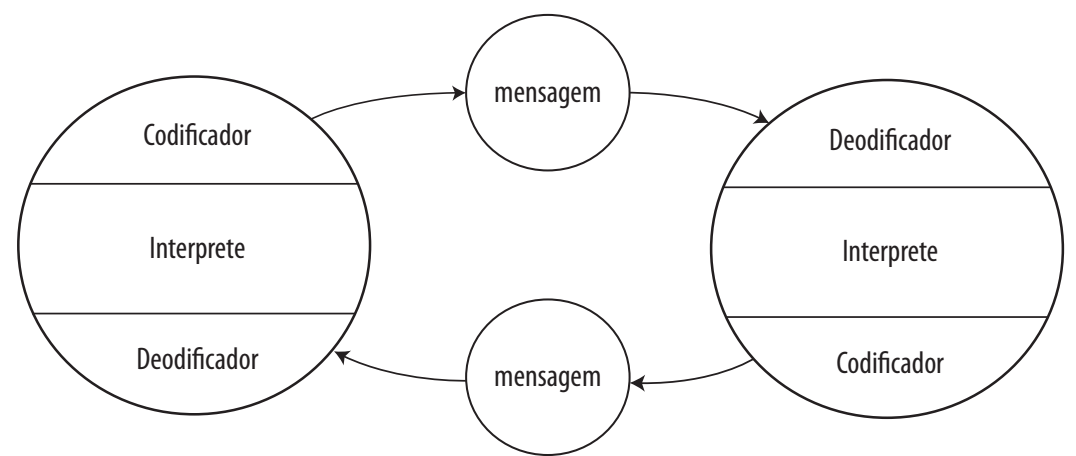

Figura 7: Representação gráfica do conceito de feedback, segundo Schramm, 1961 Fonte: Schramm, 1961, p.8, tradução nossa.

Feedback é o processo de retorno no fluxo da informação que, segundo Schramm, desempenha um papel muito importante na comunicação, porque ele nos diz como nossas mensagens estão sendo interpretadas. Exemplos de feedback apresentados pelo autor são: as respostas positivas ou uma expressões de dúvida durante uma conversa; uma carta para um editor de um jornal reclamando sobre um editorial; resposta a uma carta; o aplauso de uma plateia. Schramm acrescenta que o comunicador experimentado é atento ao feedback, e constantemente modifica a sua mensagem sob a luz do que ele observa ou ouve do seu espectador. (SCHRAMM, 1961, p. 9) 
Schramm define ainda o conceito da multiplicidade de canais, presente no seu modelo comunicacional. Segundo o autor, nós raramente mandamos mensagem em um único canal. Ele propõe que se substitua a imagem presente no modelo de Shannon e Weaver, da informação sendo transmitida por um único canal, como um telégrafo, para a da informação fluindo em vários canais simultâneos, como num cabo coaxial.

$\mathrm{Na}$ “comunicação verbal entre duas pessoas, por exemplo, há a mensagem primária, as ondas sonoras da voz, expressão facial, os gestos, a relação da mensagem dada com mensagens anteriores" que também são elementos desta comunicação. E mesmo "a mensagem primária transmite informação em vários níveis ao enfatizar, ou alterar de qualquer forma, padrão, entonação ou ritmo da fala", também alterando o significado na mensagem. (SCHRAMM, 1961, p. 9, tradução nossa)

No caso de uma informação impressa, o autor chama a atenção para elementos gráficos que atuam como canais e que alteram o significado da mensagem:

\footnotetext{
O significado é transmitido não só pelas palavras em uma notícia mas também pelo tamanho do título, a posição na página e da página no jornal, a associação com figuras, o uso do negrito e outros aparatos tipográficos. Tudo isso nos fala alguma coisa sobre a notícia. (SCHRAMM, 1961, p.9)
}

Schramm afirma que, para que haja sucesso na comunicação, ou seja, para que ela desperte a resposta desejada, ela deve ter quatro condições:

1. A mensagem deve ser construída e apresentada de forma a obter a atenção do destinatário.

2. A mensagem deve conter signos que se referem à experiência comum de fonte e destinatário, para que seu significado seja transmitido.

3. A mensagem deve despertar necessidades do destinatário, e sugerir caminhos para ir ao encontro dessas necessidades.

4. A mensagem deve sugerir este caminho, considerando a situação do destinatário em relação ao grupo em que ele se encontra. (SCHRAMM, 1969, p.13) 


\subsubsection{Convergência da comunicação}

Segundo Kincaid (2009 P. 188) a teoria da convergência na comunicação foi desenvolvida para superar deficiências dos modelos de comunicação anteriores, como o da teoria matemática da comunicação de Shannon e Weaver.

Moraes (2002), apresenta as assertivas de clássicas do modelo de convergência da Comunicação (MORAES, 2002, P. 17-18). A seguir, são apresentadas algumas dessas assertivas para melhor compreensão do diagrama a seguir:

— toda a informação e consequência de uma ação, e - através dos vários estágios do processamento informacional humane - a ação pode se tornar consequência da informação;

- 0 processo de comunicação não tem início nem fim, mas somente relações mutuas entre as partes que dão significado ao conjunto;

- A informação e o entendimento mutuo são os componentes predominantes do modele de convergência da comunicação;

- 0 processamento da informação no nível do individuo envolve percepção, interpretação, entendimento, crença e ação, que criam potencialmente, pelo menos - novas informações para posteriores processamentos;

- quando a informação e partilhada por dois ou mais participantes, o processamento da informação deve conduzir ao entendimento mutuo, a concordância mutua e a ação coletiva;

- os componentes do modelo de convergência se organizam em três de 'realidade' (ou de abstração): físico, psicológico e social;

- uma vez que a interpretação e o entendimento da informação alcançam o nível de interpretações partilhadas e o entendimento mutuo, que se considerava como processamento da informação individual torna-se comunicação humana entre duas ou mais pessoas que possuem o proposito comum (mesmo se por um breve momento) de se entenderem. (MORAES, 2002, p. 17-18)

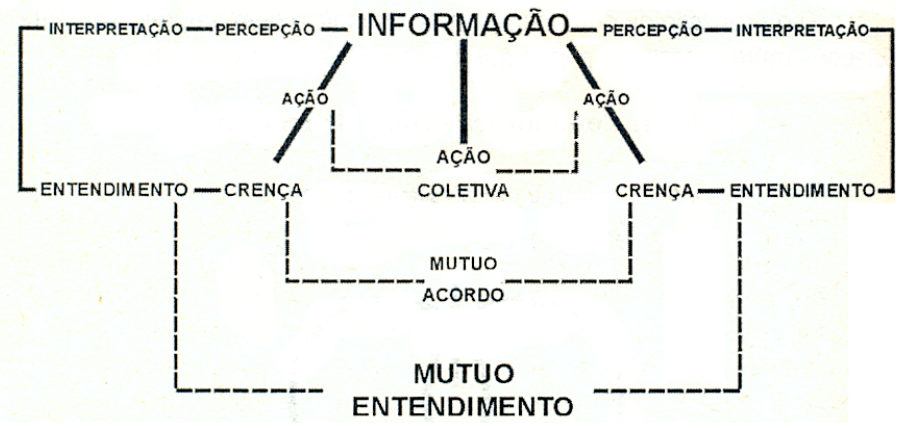


Figura 8: Versão inicial de Modelo Kincaid de Comunicação

Fonte: Moraes (2002)

Moraes (2002, p.16-19) afirma que, no modelo de convergência de comunicação define a comunicação como um processo no qual os participantes criam e partilham informações uns com os outros, de modo a alcançar mútuo entendimento. Ainda segundo a autora, os códigos ou conceitos que alguém tem disponíveis para o entendimento são aprendidos através da experiência.

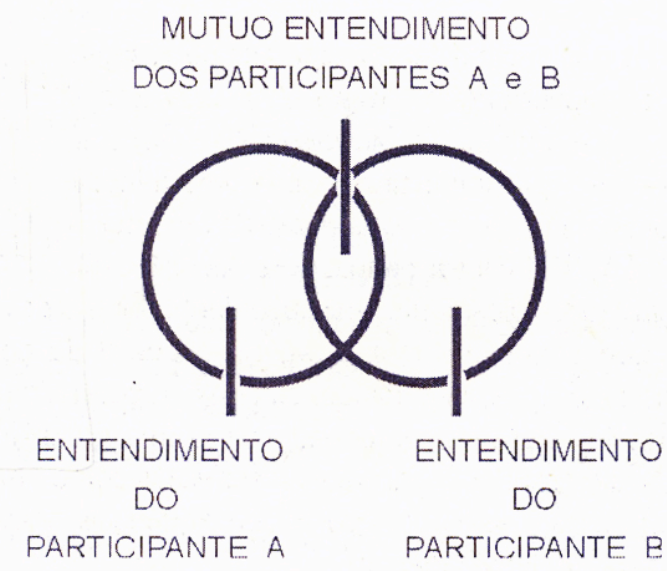

Figura 9: Comunicação como Convergência. Fonte: Moraes (2002, p.17)

Segundo Kincaid (2009, p. 189) que o conceito de convergência é distinto do conceito de consenso, e esclarece, que "convergência é o movimento a em direção [...] ao interesse comum, nunca atingindo completamente este ponto." Isto ocorre porque, ainda segundo o autor "duas pessoas nunca poder atingir o mesmo significado para informação, somente um grau maior de semelhança". (KINCAID, 2009, P.198., GRIFO DO AUTOR, TRADUÇÃO NOSSA.)

O modelo inicialmente apresentado no ano de 1979, vem sendo atualizado pelo seu autor, que o define, já no ano de 2009:

A versão atual do modelo de convergência retrata um processo cíclico e interativo, envolvendo pelo menos dois participantes. Os participantes são conectados ao compartilhar a mesma informação com o outro. A informação, localizada no núcleo central do modelo, é física ${ }^{20}$ - algo dotado de forma. Ondas sonoras criadas pelas cordas vocais, mensagens em texto em papel ou areia, padrões num monitor de televisão, linguagem

20 Segundo o autor, limitar o conceito de informação a manifestações físicas torna possível tratá-la como o meio pelo qual pensamentos e significados são expressados e compartilhados com os outros. 20 
corporal e posição, e assim por diante são fenômenos físicos e, portanto, fontes potenciais de informação na comunicação. (Kincaid, 2009, p. 198, grifo nosso, tradução nossa),

A partir da descrição de Kincaid e da representação de convergência apresentada por Moraes (2012, p. 17) foi elaborada uma representação abaixo do modelo revisto.

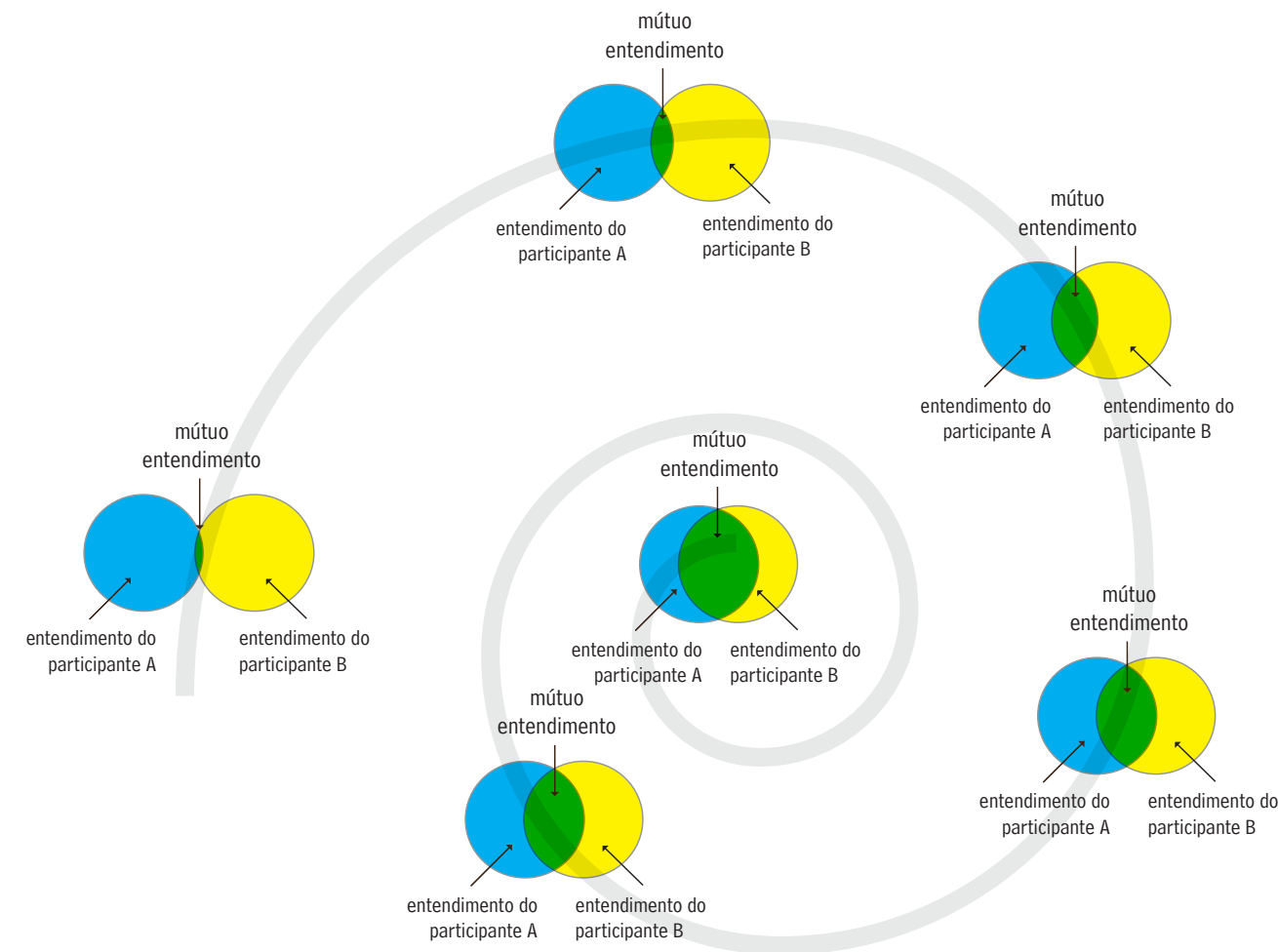

Figura 10: Apresentação gráfica do processo cíclico do compartilhamento de informação, a partir de Kincaid, 2009, e Moraes, 2002, p. 17.

$\mathrm{Na}$ revisão no seu modelo, Kincaid mantém sua definição inicial de comunicação, apresentada acima por Moraes, mas acrescenta ao modelo a possibilidade da divergência e conflito, aos elementos iniciais de convergência e cooperação. Entretanto, segundo o autor, mesmo quando o conflito ocorre, houve avanço no entendimento dos diferentes pontos de vista dos participantes do processo (KINCAID, 2009, p.189-190) 


\subsubsection{O modelo C-HIP}

O modelo de C-HIP, é um misto de modelo comunicacional e de processamento humano de informação que foi desenvolvido com o objetivo de facilitar a análise e identificação de problemas na comunicação relacionada avisos de advertências (WOGALTER, 2006 , p.51)

O modelo foi, desenvolvido por Wogalter, Dejoy a Laughery (1999, p. 1523), que agregaram elementos de dois campos: comunicação e processamento humano da informação. O nome C-HIP apresenta as duas partes do modelo: o "C" designa o componente comunicacional, e "HIP" é a sigla em inglês para processamento humano da informação - human information processing.

Os autores explicam que o modelo utiliza, da teoria da comunicação, o os conceitos de fonte, canal e receptor.

O modelo então decompõe o receptor em etapas, o modelo decompõe componente receptor em cinco etapas segundo os conceitos do processamento humano da informação: atenção, compreensão, crenças e atitudes, motivação e comportamento.

Segundo Wogalter (2006), o C-HIP é um modelo tanto de etapas como de processos, que cada etapa necessita que a anterior ocorra com sucesso, ou cria-se um "gargalo.", conforme explica o autor:

Se a informação é processada com sucesso em um determinado estágio, a informação flui para o próximo estágio. Se o processamento neste estágio não tem sucesso, ele produz um gargalo, bloqueando o fluxo da informação para o próximo estágio. Se uma pessoa não percebe ou segue uma advertência então o processamento da advertência não vai adiante. Entretanto, mesmo que uma advertência seja percebida e seguida, a pessoa talvez não entenda a advertência e, portanto, nenhum processamento adicional acontece a partir desse ponto. Mesmo que a mensagem seja compreendida, pode não ser acreditada e assim por diante através dos estágios. (Wogalter, 2006, p.52, tradução nossa) 


\section{A Fonte}

A fonte é a origem ou transmissor inicial da advertência e pode ser uma pessoa ou uma instituição. A percepção do receptor com relação à relevância da advertência varia de acordo com a credibilidade da fonte. Informação de uma fonte positiva, familiar, confiável possui maior credibilidade junto ao usuário. (WOGALTER, 2004)

O canal

O canal é o modo como a informação é transmitida da fonte a um ou mais receptores.

O autor divide o canal em duas dimensões básicas:

A primeira diz respeito ao meio pelo qual é transmitida (por ex. cartaz, livretos, de áudio ou vídeo,

A segunda, diretamente ligada a meio pelo qual a mensagem está sendo transmitida, diz respeito ao canal sensorial utilizado pelo receptor para receber a mensagem. (por ex. canal visual, auditivo, olfativo - um odor acrescentado a gases ou tátil - o mancho da aeronave que é projetado para vibrar quando há problema no motor. (WOGALTER, 2004)

\section{O Receptor}

As atividades mentais do receptor podem ser categorizadas em uma sucessão de fases de processamento da informação. Para uma advertência comunicar com eficiência e influenciar o comportamento do usuário, ela deve:

- chamar a atenção,

- manter o usuário atento à mensagem o tempo suficiente para compreendê-la.

- ser compreendida, e estar de acordo com as crenças e atitudes do receptor ou persuadir o receptor a concordar com a mensagem

a advertência deve motivar o receptor a agir com o comportamento adequado. 


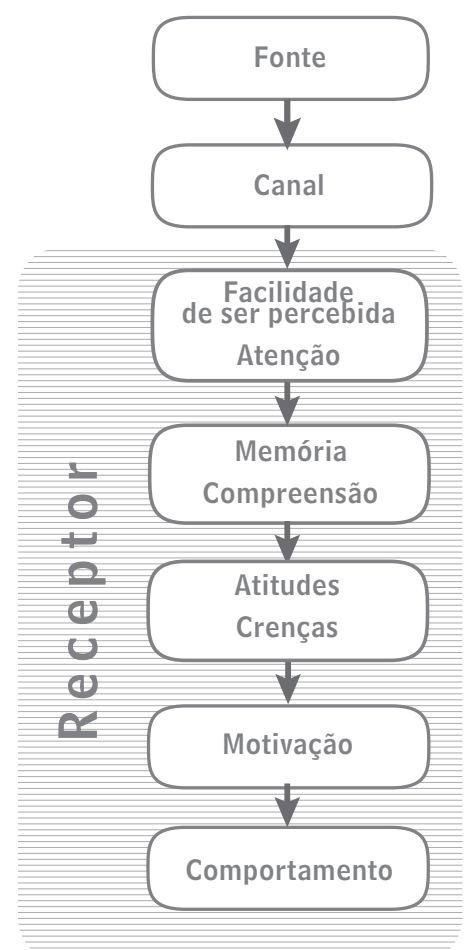

Figura 11: Modelo C-HIP, na sua primeira versão,

apresentada por Wogalter, Dejoy e Laughery, p. 15, tradução nossa.

A partir do modelo inicial apresentado em 1999, foram feitas revisões. A mais recente foi publicada no ano de 2006 (Figura 10), quando o autor explica as revisões realizadas:

A primeira [modificação] é que o estágio da atenção está agora dividido em dois estágios separados - chamada da atenção e manutenção da atenção. Estas duas etapas são afetadas por variáveis diferentes. Há também agora a etapa de entrega. Entrega se refere a interface (ou ponto de recepção ) da advertência chegando ao receptor via um ou mais canais. A terceira diferença no modelo atual é a maior ênfase na influência no estímulo ambiental. Esses três aspectos, externas à advertência afetam como a advertência é processada. Eles são extrínsecos à advertência e incluem outras pessoas, outras advertências e outros suportes no ambiente, assim como condições ambientais como a iluminação e o barulho de fundo. A quarta grande diferença do modelo inicial apresentado em 1999 é a ênfase maior nas características pessoais do receptor (por exemplo, características demográficas) e o envolvimento com as tarefas. (WOGALTER, 2006, p. 24, tradução nossa, grifos nossos. 


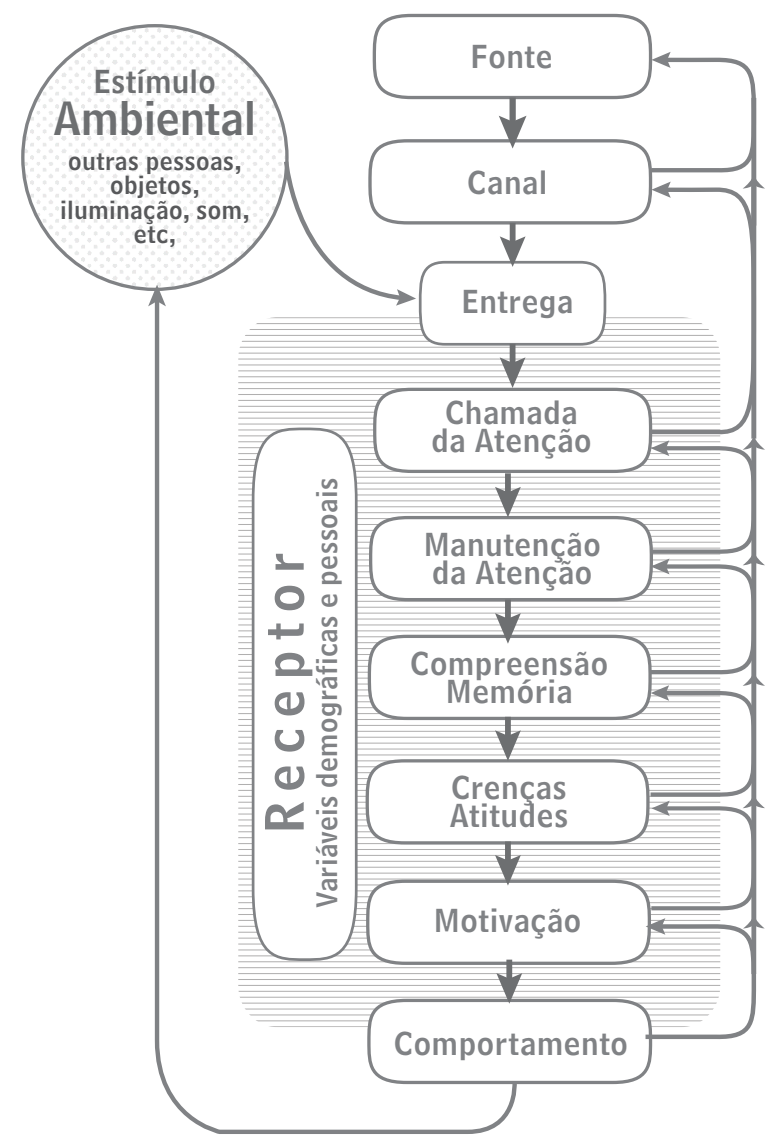

Figura 12: Modelo de Comunicação-Processamento Humano da Informação - C-HIP Fonte: Wogalter, 2006, p. 52. tradução nossa.

Outra modificação, realizada a partir da primeira apresentação do modelo é a entrada, na representação do modelo, do feedback. Apesar de ter sido apresentado desde a primeira versão, não constava da representação esquemática, e foi sendo acrescentado e discutido mais profundamente nas versões posteriores, até a apresentada em 2006. Ainda que o modelo tenda a enfatizar uma sequencia linear da fonte ao comportamento, ocorrem loops de feedback de estágios posteriores do processo.

O modelo C-HIP é de grande aplicação no campo da Ergonomia. Oliveira (2009), ao utilizar o modelo C-HIP para analisar a travessia de pedestres na rua Presidente Vargas (Rio de Janeiro), realizou levantamento, no campo de Ergodesign, de pesquisas desenvolvidas a partir do modelo C-HIP, chamando a atenção para a diversidade de temas abordados a partir do modelo. (Oliveira 2009, p. 96-98). 


\subsection{Conclusões}

Os modelos de comunicação são ferramentas relevantes para estudos que a respeito da comunicação. Os modelos expostos fornecem elementos fundamentais para a sistematização da comunicação entre pacientes crônicos e os demais atores do ciclo de utilização de medicamentos, assim como demais elementos referentes à informação na utilização de medicamentos - embalagens dos medicamentos, receita médica, entre outros - que compõe esse sistema complexo. 


\section{Delineamento da pesquisa}

\subsection{Tipo de pesquisa e fenômeno estudado}

Van Dalen e Meyer (1971, p. 226) afirmam que "o homem deve ser capaz de descrever os fenômenos que pretende estudar para poder avançar na resolução dos problemas".

Moraes (1992, p. 284) esclarece que "a Ergonomia, ao avaliar as condições de trabalho e analisar a tarefa, realiza pesquisas descritivas". Este tipo de investigação, ainda segundo a autora, "procura conhecer e interpretar a realidade, sem nela interferir para modificá-la", e trata da descoberta e da observação do fenômeno - fato tal como é percebido por alguém - buscando conhecer os processos que o constituem ou nele se realizam. (MORAES, 1992, p. 204).

Richardson (2009) defende que fenômeno - e não tema - é o termo correto para se designar o objeto do estudo científico. O autor afirma que o fenômeno tem como característica a ocupação de um lugar no tempo, e que o pesquisador sabe, portanto, que quando analisa um fenômeno deve estudar os elementos que compõem o fenômeno, suas características no tempo e no espaço (lugar). $\mathrm{O}$ pesquisador deve elaborar portanto um marco teórico de forma a caracterizar o problema.

A presente pesquisa é do tipo descritiva e, o fenômeno analisado é a utilização de medicamentos por pacientes crônicos. 


\subsection{0 problema}

A partir do referencial teórico escolhido delimita-se as características do fenômeno a ser estudado, assim como a sua relação com os outros fenômenos. (RICHARDSON, 2009, p.61). Por meio da pesquisa bibliográfica o pesquisador aprofunda o conhecimento acerca do fenômeno estudado. Passa-se, a seguir, à delimitação do problema (RICHARDSON, 2009, p.61; ALVES-MAZZOTTI; GEWANDSZNAJDER, 1999, p.65).

Richardson lembra ainda que o problema da pesquisa na área das Ciências Sociais deve: ser de natureza social; concreto; estar formulado de maneira clara e precisa $^{21}$; se referir a fenômenos observáveis; ser representativo e passível de ser generalizado; ter alguma originalidade (um novo problema ou um problema já conhecido com um novo enfoque) e não pode estabelecer juízos de valor. (RICHARDSON, 2009, p. 59-60).

Com o aumento do envelhecimento populacional ocorre um consequente aumento da parcela da população com doenças crônicas e múltiplas fazendo uso de medicamentos, muitas vezes de mais de um medicamento diariamente. (OMS, 2011; IBGE 2003). Para que a utilização dos medicamentos ocorra de forma segura e acarrete benefício à saúde do paciente, este deve estar informado a respeito do seu tratamento e apto a auto-administrar os medicamentos prescritos. (BODENHEIMER; MERRY, 2007; MALTA; MERHY, 2010) Além do aspecto relativo à tomada de informação a respeito do seu tratamento, a comunicação entre paciente e prescritor e dispensador é fundamental para que o tratamento prescrito e dispensado seja adequado. (OMS, 1998; PEPE; OSÓRIO DE CASTRO, 2000.)

$O$ problema investigado pela presente pesquisa diz respeito à comunicação deficiente no ciclo de utilização de medicamento (WAGNER, 2007; AKICI et al 2004; ANACLETO et al, 2005), - principalmente quando os pacientes têm baixa escolaridade e renda - comprometendo a capacidade do paciente em auto-administrar seu tratamento e, consequentemente, comprometendo sua eficácia. (WAGNER et al, 2001; GANDHI et al, 2000, SILVA et al, 2012).

21 Richardson afirma que é conveniente a formulação do problema sob forma de pergunta, entretanto, optou-se pela apresentação, respeitando as premissas apresentadas pelo autor, sob forma afirmativa. 


\subsection{Hipótese}

A hipótese é uma suposição objetiva, passível de teste, que procura estabelecer relação entre fenômenos (ALVES-MAZZOTTI \& GEWANDSZNAJDER, 1999, p.65).

Tradicionalmente, a formulação da hipótese é utilizada para estabelecer relações causais verificáveis por métodos quantitativos na pesquisa experimental. Entretanto, a formulação da hipótese é essencial para o delineamento da pesquisa descritiva, sendo indispensável para que o pesquisador defina, entre uma infinidade de fatos, aqueles relevantes para sua pesquisa. Segundo Van Dalen e Meyer, quando possível, deve-se fazer a verificação da hipótese a partir de um experimento, excluindo-se as variáveis não testadas e certificando-se da relação de causalidade entre as variáveis presentes na hipótese testada. Entretanto, ainda segundo os autores, para examinar fatores relacionados a determinados fenômenos é necessário pesquisá-los a partir do método descritivo, sem isolá-los do ambiente onde ocorrem. Os autores ressalvam que, ainda com todo o rigor possível na eliminação de variáveis que possam interferir nos resultados, na pesquisa descritiva nunca se chega à certeza absoluta da relação de causalidade, já que não se pode ter o mesmo controle da pesquisa experimental. Portanto, a relação de causalidade apresentada em uma pesquisa descritiva revela a associação entre os fatores, (variáveis), mas não se pode provar que uma seja causa do outro. No que diz respeito à causalidade da relação entre variáveis, ela se dá, na pesquisa descritiva, a posteriori. Ou seja, neste tipo de investigação observa-se no fenômeno a possível relação de causalidade que será observada a partir dos métodos de utilizados na investigação. (VAN DALEN \& MEYER, 1971, p. 199-266). 
Esta pesquisa investiga a hipótese de que problemas na comunicação presente no ciclo de utilização de medicamentos no tratamento de enfermidades crônicas prejudicam a autoadministração consciente dos medicamentos por pacientes crônicos/seus acompanhantes, sendo a variável independente os problemas na comunicação presente no ciclo de utilização no tratamento de enfermidades crônicas e a variável dependente — ou seja, aquela que possivelmente varia segundo alterações ocorridas na primeira - a autoadministração consciente dos medicamentos por pacientes crônicos/seus acompanhantes.

\subsection{Objetivos}

O objetivo geral desta pesquisa é descrever a comunicação presente no ciclo de utilização de medicamentos, sendo os objetivos específicos:

- levantar dados a respeito da dos problemas presentes comunicação presente no ciclo utilização de medicamentos

- identificar a rotina do usuário para lidar com esses problemas.

Os objetivos operacionais da presente investigação são: realizar entrevistas não-diretivas com pacientes crônicos, realizar questionários com pacientes crônicos, realizar entrevistas focadas com pacientes crônicos em suas residências.

\subsection{Sistematização da comunicação na utilização de medicamentos}

A partir do referencial teórico apresentado foi elaborado a sistematização da comunicação presente no ciclo de utilização de medicamentos. Na sistematização, foi destacada a interação entre o usuário e profissionais de saúde, apresentados no Capítulo 2, a partir da troca de informação com esses profissionais. A base para a sistematização do fluxo da informação está presente no Capítulo 4 desta pesquisa.

Esta sistematização, apresentada a seguir, que foi utilizada como de marco para a elaboração de etapas subsequentes desta investigação. 


\section{Ciclo de Utilização de Medicamentos}

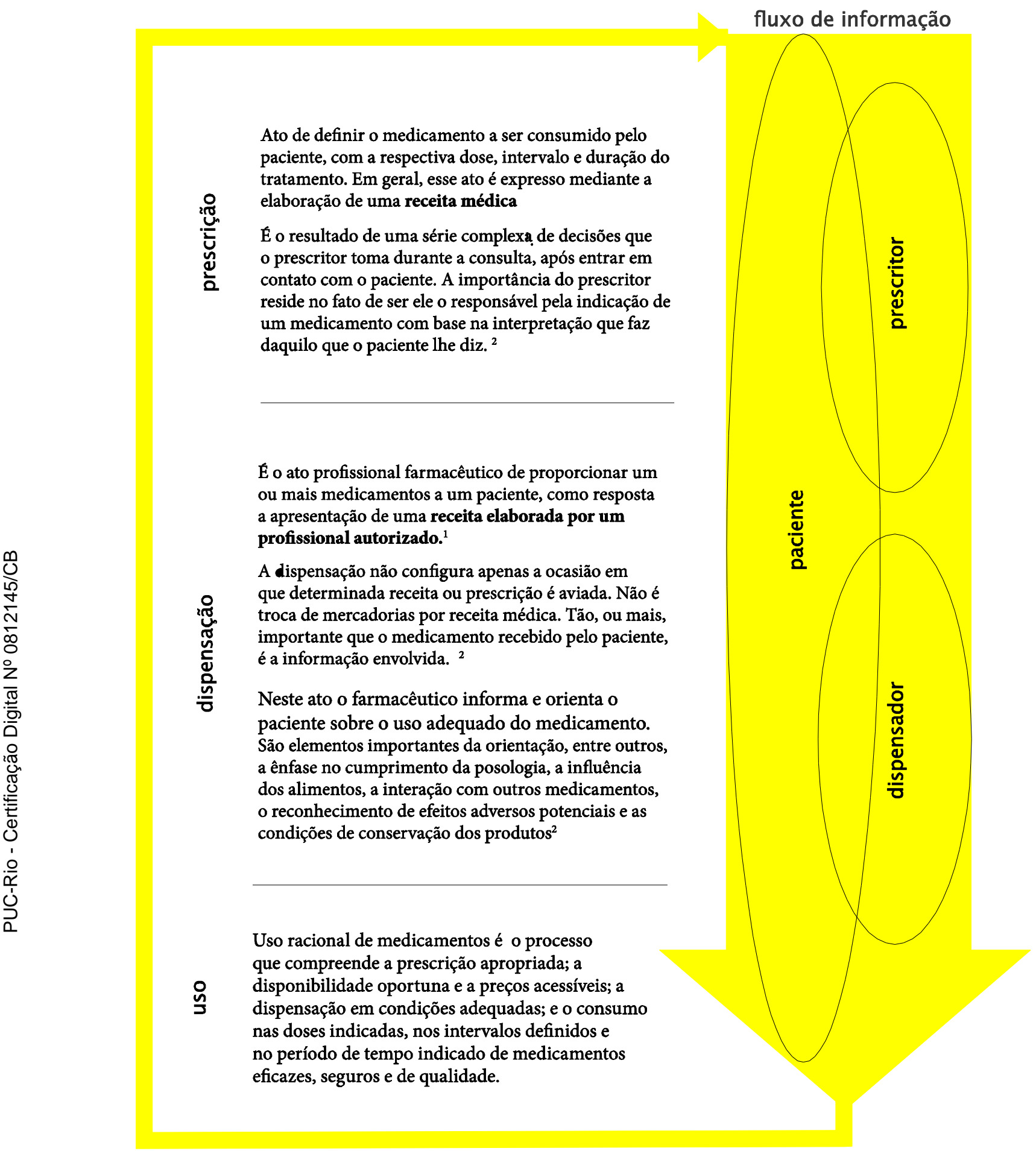

1 BRASIL. MS. Portaria no 3.916, 30 out. 1998. Diário Oficial da República Federativa do Brasil. Brasília, 1998. Prescrição de Medicamentos

2 Pepe, V. L. E. \& Osório-de-Castro, C. G. S. A interação entre prescritores, dispensadores e pacientes: informação compartilhada como possível benefício terapêutico. Cad. Saúde Pública, Rio de Janeiro, 16(3):815-822, jul-set, 2000. 3 OLIVEIRA, M. A.; BERMUDEZ, J. A. Z. OSORIO-DE CASTRO, C. G. S. Assistência farmacêutica e acesso a medicamentos. Rio de Janeiro: Editora Fiocruz, 2007.

Quadro 1: Ciclo de utilização dos medicamentos

Quadro desenvolvido pela autora a partir do referencial teórico apresentado 


\section{Métodos e técnicas}

A pesquisa elaborada é do tipo descritiva e foi realizada em duas etapas:

Na primeira etapa foram utilizados os seguintes métodos:

- Elaboração de referencial teórico

- Entrevistas não-diretivas com pacientes com doenças cardiovasculares

- Questionários com pacientes com de doenças cardiovasculares autorreferidas.

$\mathrm{Na}$ segunda etapa foram realizadas entrevistas focadas com pacientes com doenças crônicas autorreferidas, moradores da comunidade da Mangueira.

\subsection{Pesquisa bibliográfica}

A pesquisa bibliográfica representa etapa fundamental na pesquisa, tanto descritiva quanto experimental. É pelas informações obtidas nesta etapa que é caracterizado o fenômeno estudado e, a partir disto, definido o problema da pesquisa.

A partir da pesquisa bibliográfica realizada a respeito do fenômeno estudado: a comunicação na utilização de medicamentos por pacientes com doenças crônicas, com o material levantado, foi estruturado o referencial teórico da presente pesquisa, apresentado em três partes, que constituem os capítulos 2, 3 e 4 do presente documento.

- Doenças crônicas e a relevância do paciente no seu tratamento.

A respeito de doenças crônicas, incidência, e elementos que promovam a utilização efetiva dos medicamentos e o papel do paciente neste sistema. 


\section{— Utilização de medicamentos e comunicação.}

Apresenta o conceito de assistência farmacêutica, detendo-se o na etapa em que o usuário/paciente está envolvido diretamente - a utilização de medicamentos - e as fases que a constituem: prescrição, dispensação. É também exposto o conceito de comunicação e de sistematização da informação e de conceitos básicos utilizados nesta sistematização.

\section{— Ergonomia e assistência em saúde}

Apresenta a definição de Ergonomia, seus campos de especialização. Em seguida, enumera pesquisas de ergonomia relacionadas à assistência em saúde, expondo a abordagem da sua colaboração neste campo, com foco especial na atenção primária, etapa da assistência em saúde na qual se insere o fenômeno estudado nesta investigação.

\subsection{Ferramentas de pesquisa: primeira etapa}

Na primeira etapa da pesquisa, a fim de explorar o campo estudado a partir da voz do usuário, optou-se pela aplicação de dois métodos: entrevistas nãodiretivas e questionários.

\subsubsection{Entrevistas não-diretivas}

A entrevista não diretiva — também chamada de entrevista não estruturada ou entrevista em profundidade - é um método de caráter aberto, adequado para se iniciar pesquisa com os usuários procurando não impor uma visão de realidade ou (para quem) não conhece bem a população entrevistada. Neste método, o pesquisador não prepara perguntas pré-formuladas, mas sim visa obter do entrevistado sua descrição do problema estudado (RICHARDSON, 1999, p. 208). Alvez-Mazzoti e Gewandsznajder (1999, p. 168) afirmam que a entrevista não diretiva deve ocorrer quando o pesquisador está interessado "no significado atribuído pelos sujeitos a eventos, situações, processos ou personagens que fazem parte de sua vida cotidiana “. 
Richardson lembra que outros métodos de inquirição - como entrevista estruturada e questionários — são adequados quando o pesquisador já sabe quais são as perguntas mais relevantes e as respostas mais frequentes. Ele também lembra a importância da interação face a face nas investigações que envolvem indivíduos. Segundo o autor, não se pode tentar colocar-se no lugar da outra pessoa; é necessário efetivar uma interação. (RICHARDSON, 1999, p. 207)

Optou-se então pelo método de entrevista não-diretiva técnica exploratória, utilizando-se como base para a aplicação do método Mucchielli (1978) a fim de embasar as próximas etapas de inquirição da pesquisa, diminuindo, desta forma, a presença dos pressupostos do pesquisador e se considerando mais o discurso do paciente a respeito da utilização de medicamentos.

Foram realizadas nesta etapa 20 entrevistas não-diretivas com pacientes cárdicos em tratamento ambulatorial ou seus acompanhantes. As entrevistas foram realizadas durante o período de espera para o atendimento ambulatorial.

\subsubsection{A análise de conteúdo}

Richardson (2009) afirma que "As definições de análise de conteúdo tem mudado através do tempo, à medida que se aperfeiçoa a técnica e se diversifica o campo de aplicação, com a formulação de novos problemas e novos materiais". Richardson, 2009, p. 222)

A técnica é utilizada em pesquisa a fim de operacionalizar informações presentes em determinado conteúdo. Entretanto, Mucchielli (1982) explica que a análise de conteúdo é uma atividade natural e necessária, que realizamos diariamente, à medida que percebemos e compreendemos, por exemplo, um livro ou um filme. Segundo o autor "A análise da informação é uma operação vital e crucial sem o qual não há utilização possível da informação, ou seja, não há informação alguma" (MUCHIELI, 1982, p.5, tradução nossa).

\subsubsection{O Corpus}

Segundo Mucchielli, (1982, p. 38) o corpus é o conjunto de dados sobre o qual se vai ou se deve efetuar a análise de conteúdo. 
Ainda segundo o autor, em muitos casos o corpus é constituído facilmente: ele é, por exemplo, a totalidade das respostas obtidas a uma questão aberta colocada a um grupo definido de pessoas.

O corpus foi composto pelo total das 20 entrevistas realizadas. O início da entrevista foi considerado o próprio início da gravação. Isto ocorreu após o consentimento por parte do entrevistado para que o gravador fosse ligado, depois do esclarecimento sobre o teor da pesquisa e seus objetivos. O fim da entrevista foi considerado a última frase anterior à aplicação do questionário de dados sociodemográficos.

\subsubsection{A categorização}

Segundo Bardin a análise de conteúdo é a organização do texto, que passa por sucessivas etapas de recorte, agregação e enumeração. Ao fim deste processo chega-se a uma representação/expressão do conteúdo, que esclarece ao pesquisador as características do texto. (1977, p. 103)

Bardin lembra a definição de Holsti:

\footnotetext{
A codificação é o processo pelo qual os dados brutos são transformados sistematicamente e agregados em unidades, as quais permitem uma descrição exata das características pertinentes do conteúdo. (HOLSTI, 1969, apud BARDIN, 1977, p.103)
}

Segundo Mucchielli (1982, p. 35) ou as categorias são deduzidas da hipótese do trabalho ou elas são induzidas de um conteúdo sobre o qual não foram formuladas hipóteses.

$\mathrm{Na}$ presente pesquisa, as categorias foram definidas a partir da hipótese que problemas na comunicação presente no ciclo de utilização no tratamento de enfermidades crônicas prejudicam a autoadministração consciente dos medicamentos por pacientes crônicos/seus acompanhantes. 


\subsubsection{As unidades de codificação}

Segundo Mucchielli (1982, p. 31), se queremos mais do que uma "impressão geral e pessoal" do sentido do texto, se queremos "medir" algo, a análise de conteúdo deve necessariamente cortar o conteúdo em pedaços para em seguida efetuar todas as operações necessárias. O problema é saber qual será a unidade de recorte: se a palavra, a proposição, o parágrafo, a página ou o artigo inteiro.

$\mathrm{O}$ autor apresenta então dois tipos de unidade: unidade de numeração e unidade de registro e de contexto, sendo a unidade de numeração utilizada para comparação quantitativa entre textos. A unidade de contexto será o trecho classificado entre as categorias da análise. Mucchielli esclarece que não há como definir um tamanho específico para cada unidade. O autor pondera que para o analista de conteúdo o essencial é o sentido e não a forma.

Portanto, o recorte da unidade de contexto será a princípio diferente que o da linguística clássica. Mucchielli ressalta que é absolutamente inútil se questionar se a palavra, a proposição ou a frase são as unidades de significação, uma vez que se deve procurar a unidade de sentido no próprio sentido.

Conforme Mucchielli, para se realizar a análise mais minuciosa, que corresponderia na linguística à análise palavra-a-palavra, se recortará o texto nas menores unidades de sentido possíveis em uma mesma sequencia textual. Às vezes uma palavra, às vezes um grupo de palavras, à medida que forem estas ou aquelas unidades linguísticas que contêm o elemento de sentido.

Em Mucchielli (1982, p. 33), o elemento de sentido, mesmo em níveis mais elementares, formam um conjunto que inclui:

a) Uma função central ou "núcleo de sentido", com uma ou múltiplas funções-apoio, mais ou menos parasitas, que são as redundâncias, os efeitos de estilo ou as referências às informações puras. 
b) uma função indicial, pela qual o elemento de sentido se torna indicativo, de forma mais ou menos alusiva, de uma atitude geral, de uma atmosfera ou de uma ideologia. $^{22}$

A partir do referencial descrito por Bardin (1982) e Mucchielli (1982), foi feita uma leitura inicial do corpus. A partir disto foi realizada a categorização, a partir da hipótese da investigação, das falas dos respondentes.

\subsubsection{Questionário}

Segundo Mucchielli (1978b, p.12):

O maior erro que pode se cometer, - e que normalmente é muito difundido - é acreditar que um fenômeno social seja uma soma de pequenos fenômenos individuais e que teremos dele uma ideia suficientemente clara depois de percorrermos como um turista-observador as áreas onde ocorre.

A realidade social tem uma vida que lhe é própria, irredutível à vida dos indivíduos e o problema é justamente o de captar certos aspectos dessa vida coletiva através da observação e da opinião dos indivíduos.

[...]

A apreensão da realidade psicossocial é delicada e pode-se dizer igualmente que os instrumentos para essa captação devem ser regulados com cuidado e ciência.

Ainda segundo Mucchielli (1978b, p. 15), há três grandes categorias de métodos: observação; entrevistas individuais e coletivas e questionários.

Os questionários podem ser preenchidos pelos entrevistados, ou as respostas dadas pelos respondentes podem ser anotadas pelo pesquisador. Este tipo de questionário, no qual as respostas dadas pelos respondentes são anotadas pelo pesquisador, também é chamado de formulário por alguns autores de metodologia, como Gresseler (2003).

\footnotetext{
22 Para exemplificar a utilização do método descrito por Mucchielli na presente pesquisa, tomemos como exemplo um trecho destacado de uma das entrevistas não-diretivas concedidas: “Eu já deixo a receita em cima da mesinha onde eu guardo meu remédio, então pra mim controlar meu remédio, que eu tomo, olhando pela receita eu vejo o horário".

Neste recorte considerou-se a função central, ou núcleo de sentido, o seguinte trecho: deixo a receita em cima da mesinha onde eu guardo meu remédio", sendo as funções de apoio o trecho inicial "eu já deixo", que enfatiza o fator facilitador da proximidade entre o local onde o respondente guarda a receita e o remédio. O trecho a seguir: então pra mim controlar meu remédio, que eu tomo, olhando pela receita eu vejo o horário" foi interpretado como apresentando a função inicial, adicionando ao núcleo de sentido apresentação da atitude de uso do medicamento a partir da consulta periódica da receita.
} 
Optou-se pela utilização do questionário onde as respostas são anotadas por pesquisador a fim de minimizar as diferenças de escolaridade entre entrevistados, visto que este fator, ainda que participe do processo de compreensão do tratamento, não é o foco da pesquisa.

Para Mucchielli:

A ideia de uma enquete brota no espírito de um dirigente sob a pressão de um problema geral que deve ser resolvido na prática, e o objeto da enquete é uma definição mais precisa a partir da ideia, e uma delimitação do seu campo com o máximo de clareza (Mucchielli (1978b, p.19)

Conforme o autor, para se chegar ao objetivo é necessário determinar o alvo visado pelo promotor da enquete:

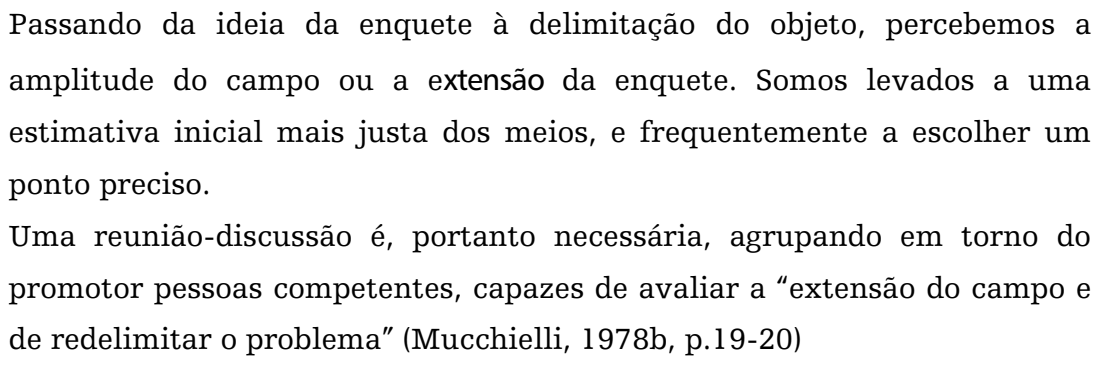

Segundo Mucchielli (1978b, p.21) a pré-enquete é o essencial da fase preparatória da enquete: é uma etapa de procura de hipóteses possíveis, mas de hiopóteses verificáveis.

\title{
7.2.3.1 A construção do questionário
}

Segundo Mucchielli:

\begin{abstract}
a resposta procurada é idealmente, aquela que, através da subjetividade dos indivíduos (e mesmo, por vezes, à revelia de sua consciência refletida) exprime direta ou indiretamente (mas sempre da maneira mais útil e utilizável possível) o fenômeno mundial que queremos conhecer ou compreender (1978b, p.15).
\end{abstract}

A partir dos resultados obtidos na etapa anterior, a análise de conteúdo das entrevistas não-diretivas, optou-se por focar o questionário no uso dos medicamentos. A opção foi feita por este aspecto ter tido o maior número de trechos codificados, tanto nos problemas e dificuldades como nos métodos e soluções apresentados nas respostas. 
Foi feita então uma releitura dos trechos codificados com o propósito de aproximar a linguagem do questionário aos termos usados pelos pacientes ao relatarem sua rotina.

Houve a necessidade de incluir no questionário tanto perguntas diretamente relacionadas aos trechos codificados na categoria "uso dos medicamentos" como colocações feitas pelos pacientes que, ainda que não fossem especificamente desta etapa, influenciam diretamente. Podemos citar como exemplo a pergunta a respeito do entendimento, pelo paciente, do que é dito médico. Problemas neste aspecto influem na segurança e conformidade do uso dos medicamentos. Outro tipo de pergunta que se distinguia um pouco das demais foi relacionada à compreensão do paciente a respeito de instruções por intervalo de horário como "de 8 em 8 horas", ou "de 12 em 12 horas". Observou-se que, entre os pacientes entrevistados, houve insegurança ao descrever a prescrição colocada desta maneira. Por ser considerado elemento crucial de informação da prescrição, uma seção a respeito desta hipótese foi incluída.

Optou-se também pela redundância de perguntas consideradas chave para a hipótese testada para, no questionário final, optar-se pela redação mais adequada.

O questionário-piloto (Anexo 1) foi então composto de 38 perguntas, sendo as respostas variadas entre perguntas abertas - com opções de respostas a serem marcadas que não eram faladas ao entrevistado -, escala de opinião e uma parte final especificamente a respeito dos intervalos de horário, um quadro de horas para anotação da resposta dada.

\subsection{Ajustes realizados a partir do questionário-piloto}

O questionário-piloto (Apêndice 1) mostrou-se longo demais, tendo durado por volta de 40 minutos a aplicação de cada um deles.

Entretanto, observou-se a necessidade de se aumentar o espaço e incluir mais opções para algumas perguntas. Notou-se também que a diagramação em duas colunas, assim como outros recursos para que o questionário tivesse o layout mais compacto e, portanto, pudesse ser impresso em menos páginas, dificultou a aplicação. Além disso, as perguntas 1 e 28 tiveram sua forma bastante modificada, ocupando mais espaço do que na versão inicial do questionário.

No questionário final houve então um aumento no número de páginas, mas o volume de perguntas ficou reduzido em relação à versão inicial. 
Outra modificação estrutural foi a organização mais precisa dos setores do questionário por páginas. ${ }^{23} \mathrm{~A}$ seguir será apresentado, a partir da numeração do questionário piloto, as alterações realizadas.

\section{- Apresentação}

Notou-se necessidade de uma melhor redação na apresentação do questionário e da inserção das marcas oficiais, Puc-Rio - Pontifícia Universidade Católica do Rio de Janeiro, e Leui - Laboratório de Ergonomia e Usabilidade de Interfaces em Sistemas Humano-Tecnologia PUC-Rio.

\section{- Pergunta 1}

Esta pergunta é fundamental para a pesquisa, e tem como hipótese que os pacientes organizam o uso dos medicamentos a partir de hábitos cotidianos, em especial os horários da alimentação e descanso. Entretanto, notou-se que os pacientes descreviam sua rotina inicialmente listando os medicamentos que tomam. A pergunta foi então transformada em uma tabela, com espaço para que essa descrição fosse anotada de forma mais eficiente. Para isso, a pergunta, passou a ocupar, juntamente com a apresentação do questionário, toda a página 1 do questionário final.

- A pergunta 2 foi alterada: a redação da pergunta de "O Sr. (a) consegue seguir direitinho o que está na receita?" para "O Sr. (a) costuma seguir o que está na receita?. Essa alteração ocorreu porque, na prática, a primeira redação soou infantilizada. Esta pergunta tem como função, mais do que a obtenção de resposta, introduzir o respondente ao tema do enquete. Isto porque a resposta para este tipo de pergunta, realizada em etapas anteriores da pesquisa, demonstrou que o pacientes costumam responder positivamente a este tipo de questionamento ${ }^{24}$.

- as perguntas 3 e 3.1 "O Sr. (a) passa do horário que tem que tomar o remédio? quando passa, como o Sr. (a) faz?" foram resumidas a uma "Se o sr. (a) passa do horário que tem que tomar o remédio, como o sr. (a) faz?"

- a pergunta 4, sobre a relação do tamanho com o efeito do medicamento, foi retirada do questionário final por nenhum dos respondentes do questionário piloto ter considerado essa relação.

23 A páginas e numeração das perguntas se remetem ao questionário piloto (Apêndice 1)

24 Isto pode ser observado especialmente durante as entrevistas não-diretivas. Esta pergunta era muitas vezes feita de forma a introduzir o entrevistado ao tema. A partir daí notou-se que, ao longo da entrevista, mais a vontade, o paciente descrevia uma rotina de adesão mais baixa ao tratamento medicamentoso do que a resposta inicial indicava. 
- a pergunta 5, O Sr. (a) deixa de comprar algum remédio que o médico passou na receita?" foi reformulada, pois as respostas a essa pergunta eram relacionadas ao número de medicamentos não-comprados, e não à frequência com a qual os medicamentos não são adquiridos. A redação final então foi “ $O s r$. (a) já deixou de comprar algum remédio que o médico passou na receita ?”.

- na pergunta 6, "Algum remédio que o médico 'te 25 passou 'te' dá um incômodo tão grande que você não consegue tomar?", o termo "te dá" foi substituído por "já te deu” pois as respostas muitas vezes se remetiam a uma situação passada que, entretanto, interessa a esta pesquisa.

- na pergunta 6.1, a Sinvastatina foi incluída entre as respostas.

- na pergunta 6.2 "O sr. (a) ache que o médico sabe que este remédio 'te' incomoda", foi incluída as respostas "tenho certeza que sim”, e tenho certeza que não" na escala de opinião.

- a pergunta 6.3 foi retirada, por ser um aprofundamento de questão não ligada diretamente ao foco da pesquisa.

Notou-se que a numeração da pergunta 6 estava repetida, o que foi corrigido.

- a pergunta 7 teve sua redação alterada de "O Sr. (a) toma os remédios quando:" para "Quando o Sr. (a) está se sentindo bem, o Sr. (a) deixa de tomar os remédios ou continua tomando?", pelo fato da primeira versão ter ficado pouco clara para os entrevistados.

- pergunta 8, a respeito do uso de diuréticos, pareceu específica demais e fora do foco do questionário, além de não ter havido resposta que indicasse mudança de rotina na administração por nenhum dos respondentes. Por isso foi retirada da versão final questionário.

- a pergunta 9 foi retirada do questionário final por ser redundante em relação à pergunta 7, e esta ter funcionado melhor na aplicação do piloto

- na pergunta 10 foram incluídas respostas de mais locais específicos (além da caixinha, na versão piloto) onde os pacientes descreveram guardar os medicamentos. Duas outras respostas foram cortadas, por haver redundância.

250 pronome 'te' foi utilizado ao invés de "lhe" para aproximar a redação do questionário à linguagem falada que seria usada no momento da aplicação deste. 
- na pergunta 11 as respostas foram redigidas de forma a serem melhor identificadas pelo pesquisador na aplicação do questionário . "dentro da caixa, dentro da cartela" passou a ser "na caixa" (pois a cartela está subentendida), e "dentro da cartela/fora da caixa" passou a "na cartela > fora da caixa".

- a pergunta 12 foi retirada, pois causou confusão uma vez que os respondentes já haviam, a essa altura da aplicação do questionário, descrito sua rotina.

- a pergunta 13 foi alterada de "O Sr. (a) costuma levar os medicamentos quando sai de casa?”, para "Quando sai, o sr. (a) leva os remédios?”, e a resposta "de vez em quando" foi substituída por "só quando vai passar a noite fora", pois observou-se não ser uma questão de periodicidade o que está envolvido na rotina do paciente, e sim do período que vai passar fora de casa. As respostas da pergunta 13.1 também foram ajustadas conforme o descrito pelos respondentes do questionário-piloto sendo, por exemplo, incluída a resposta "cartelas na carteira", por ser uma forma comum dos homens guardarem o medicamento.

- As perguntas 14 e 15 foram alteradas para "Se eu tirar todas as cartelas dos seus remédios das caixas e colocar em cima de uma mesa uma do lado da outra, o sr. (a) sabe me dizer qual é qual?" e "Se eu tirar um comprimido de cada remédio e colocar todos em cima de uma mesa, Sr. (a) sabe me dizer qual é qual? pois foi falando dessa forma que os pacientes compreendiam o teor da questão.

A ranhura do comprimido foi incluída nas respostas à pergunta 15 , por ter sido descrito como elemento de identificação dos medicamentos por uma respondente.

- uma pergunta foi incluída entre as perguntas 14 e 15, pois pacientes indicaram que o fato do comprimido estar visível dentro da cartela facilitava a identificação do medicamento a ser tomado. Esta pergunta parte da hipótese que as características (cor, forma, inscrições, etc.) do comprimido são um elemento importante na identificação do medicamento.

- após a pergunta 15 foi incluída uma pergunta relativa ao local onde o paciente guarda a receita. Esta pergunta parte da hipótese de que a receita é um elemento importante de informação do paciente. Esta hipótese partiu da observação de que pacientes mantêm, em suas casas, a receita em local acessível/visível. 
A pergunta 16 "O Sr. (a) usa ou já usou a caixinha de portacomprimidos?" foi alterada pois a análise do porta-comprimido pelo paciente não requer necessariamente seu uso. A pergunta no questionário final foi então “ $O S r$. conhece aquela caixinha porta-comprimidos, de colocar os comprimidos separados nela?" e nas respostas estavam incluídos tanto itens para usuários como para não-usuários da caixinha.

- as perguntas 17 e 18 foram eliminadas por serem redundantes em relação a outras, de melhor redação, já presentes na versão final do questionário.

- as perguntas 19 a 24 partem da hipótese de que a informação ao paciente relativa à rotina de uso de medicamentos, quando feita pelo intervalo entre doses (por ex. 8 em 8 horas), muitas vezes não é compreendida. Observou-se que pacientes entrevistados tiveram dificuldade de compreender que a pergunta não dizia respeito especificamente à sua prescrição. Três medidas foram tomadas então:

1) Estas perguntas foram passadas para o final do questionário, quando todas as perguntas sobre o tratamento do paciente já terão sido feitas;

2) Foi aberta uma nova seção, com o seguinte enunciado: “As perguntas que vou te fazer agora são um pouco diferentes. Não são sobre os remédios que o sr. (a) toma, mas como se fosse um remédio novo que um médico receitou."; e a redação da pergunta individualmente foi alterada de "Se um remédio tem que ser tomado duas vezes ao dia, a que horas o Sr. (a) tomaria?" para "Se esse outro remédio tivesse que ser tomado duas vezes ao dia, em que horário o sr. (a) tomaria?"

Notou-se também que havia perguntas demais a respeito de intervalos de tomada de medicamentos, confundindo o paciente nas respostas. Optou-se por excluir as perguntas 21 e 24, relativas ao intervalo de 6 em 6 horas, por este não ter sido observado em nenhuma prescrição.

A pergunta 28, colocada inicialmente para haver redundância no questionário-piloto, mostrou-se muito clara para os pacientes, que respondiam com agilidade aos itens. Ela foi então mantida, ampliada e acrescentou-se às respostas uma escala da avaliação e um pequeno espaço para as breves observações que normalmente eram feitas pelo paciente sobre cada item. Esta pergunta ganhou, portanto, mais espaço na nova diagramação. 


\section{Ajustes gerais}

Juntou-se, na página 2 do questionário final, as perguntas que não apresentavam questões específicas da rotina diária administração (foco do questionário), mas questões mais gerais relacionados a esta rotina. Ela compreende as perguntas 1 a 9 do questionário-piloto revistas.

Notou-se a necessidade de se utilizar em todas a perguntas o termo "remédio", pois observou-se que na aplicação o uso da palavra "medicamento", apresentou mais dificuldade para ser compreendida.

\subsection{Ferramentas da pesquisa: segunda etapa}

Para a realização desta etapa da pesquisa foi solicitada a apreciação da comissão de ética da Pontifícia Universidade Católica do Rio de Janeiro, que homologou parecer favorável, em anexo. (Anexo 2)

\subsubsection{Entrevistas focadas}

Foram realizadas 10 entrevistas focadas com moradores da comunidade da Mangueira. As entrevistas foram todas realizadas nas residências dos entrevistados, nos dias 3, 4 e 8 de novembro de 2011.

A opção pela comunidade da Mangueira se deu por esta representar uma comunidade de baixa renda (CUNHA, 2000), tendo seus habitantes, portanto, potencialmente mais sujeitos aos fatores de risco de doenças crônicas e a menos acesso a tratamento adequado, conforme apresentado no Capítulo 2 da presente pesquisa.

Foram entrevistadas 10 mulheres residentes na comunidade da Mangueira. Nove delas são pacientes com enfermidades crônicas e uma administra o tratamento da mãe. O tipo de amostra utilizada foi do tipo não-probabilística acidental (RUDIO, 1980. p. 51), como usado anteriormente nos métodos de entrevista e questionário. 
Optou-se por realizar as entrevistas fora do ambiente hospitalar. Esta decisão foi tomada após a observação de que os pacientes, quando entrevistados no ambiente onde são atendidos, relacionam a pesquisa à instituição de saúde. Isto pode causar distorção nas respostas uma vez que as declarações dadas podem estar associadas a alguma repercussão no ambiente onde o paciente é atendido. Isto foi observado durante as entrevistas não-diretivas quando a pesquisadora frequentemente ouvia tanto queixas a respeito de algum aspecto do atendimento ou da instituição, como percebia constrangimento do respondente em expressar-se livremente. 
A escolha por todas as entrevistas serem realizadas, não só na comunidade onde residem, mas também dentro da residência dos entrevistados, se deu para viabilizar a observação, pelo pesquisador, do ambiente onde o medicamento é administrado. Assim foi possível observar não só o relato do paciente a respeito da administração, como também a apresentação dos elementos que fazem parte desta rotina como: os próprios medicamentos, locais onde eles são guardados e prescriçõesmédicas. A interação inicial e convite para participação do entrevistado na pesquisa foi feita com o apoio de Maria Aparecida Rodrigues — a Cida moradora local, que se dispôs a colaborar com a pesquisa. Ela reside na Mangueira há 22 anos e foi um elo facilitador por avalizar, para os entrevistados, a boa fé da pesquisadora. Isso facilitou a aceitação dos respondentes em participar da entrevista, uma vez que a entrada na residência demanda confiança. A presença de Maria Aparecida na abordagem dos entrevistados e, posteriormente, durante as entrevistas, foi fundamental também para o trânsito da pesquisadora na comuidade, já que a Mangueira não era um ambiente familiar a ela. Uma tarefa como a localização da casa de um possível paciente crônico seria extremaente difícil sem a ajuda de Maria Aparecida, uma vez que a localização é feita com indicações comuns para a comunidade mas desconhecidas para alguém de fora. Um exemplo de indicação de uma determinada residência poderia ser: “- Lá nos predinhos, em cima da Dona Maria do Tito". Além disso, a comunidade da Mangueira, até recentemente, era dominada por facção criminosa. Hábitos são construídos em uma comunidade que conviveu durante décadas com com o tráfico de drogas e a violência armada. Eles são presentes mesmo após a ocupação da polícia ocorrida em 9 de junho de 2011, cinco meses antes da pesquisa. Um desses hábitos é o de não dar informações a pessoas de fora da comunidade. A convivência com estes hábitos demanda um conhecimento não comum à pesquisadora. Por isto a colaboração da Cida foi essencial para a realização desta etapa da pesquisa. 


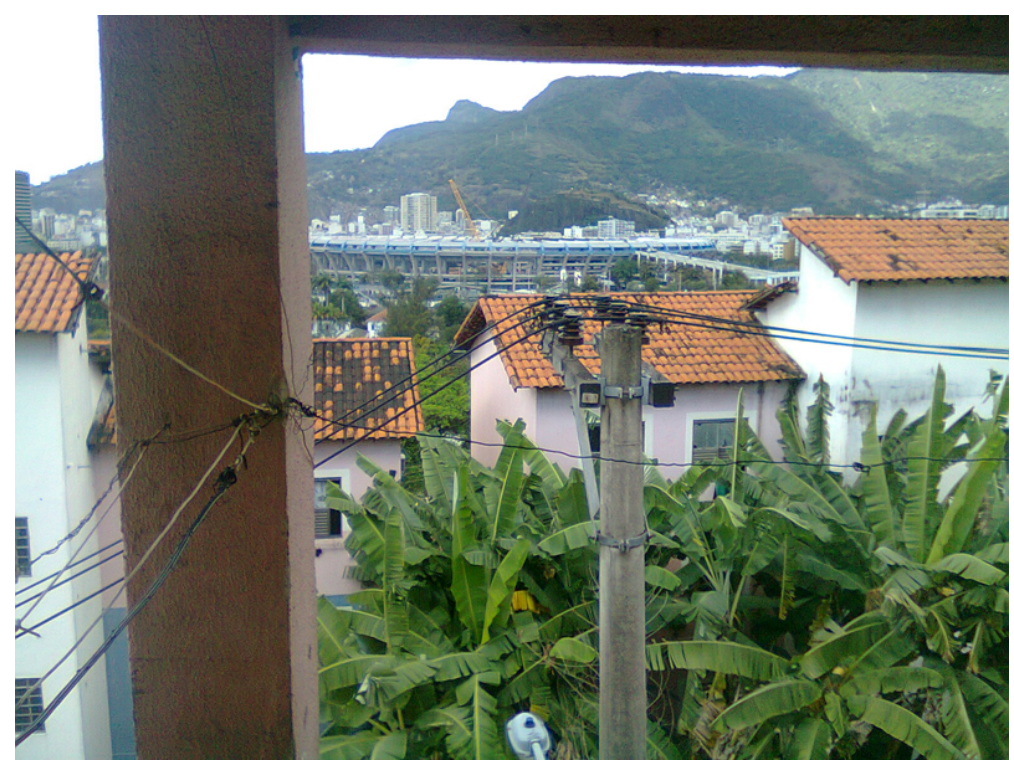

Foto 1: Mangueira, do alto do morro. (foto tirada pela pesquisadora)

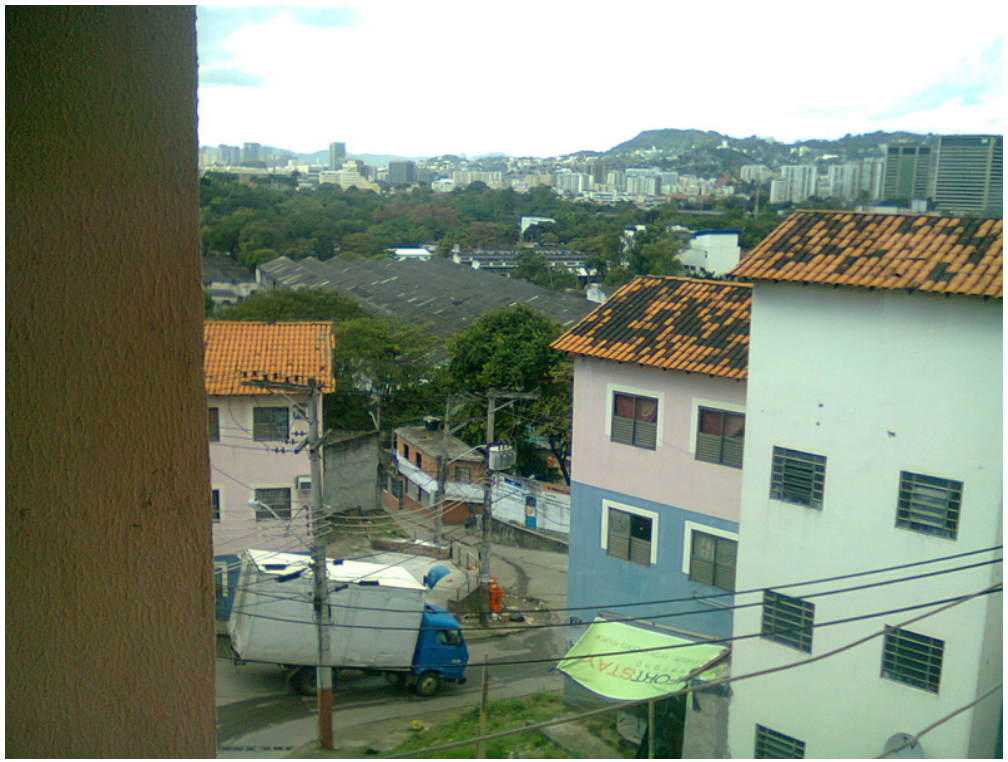

Foto 2: Mangueira, do alto do morro. (foto tirada pela pesquisadora) 


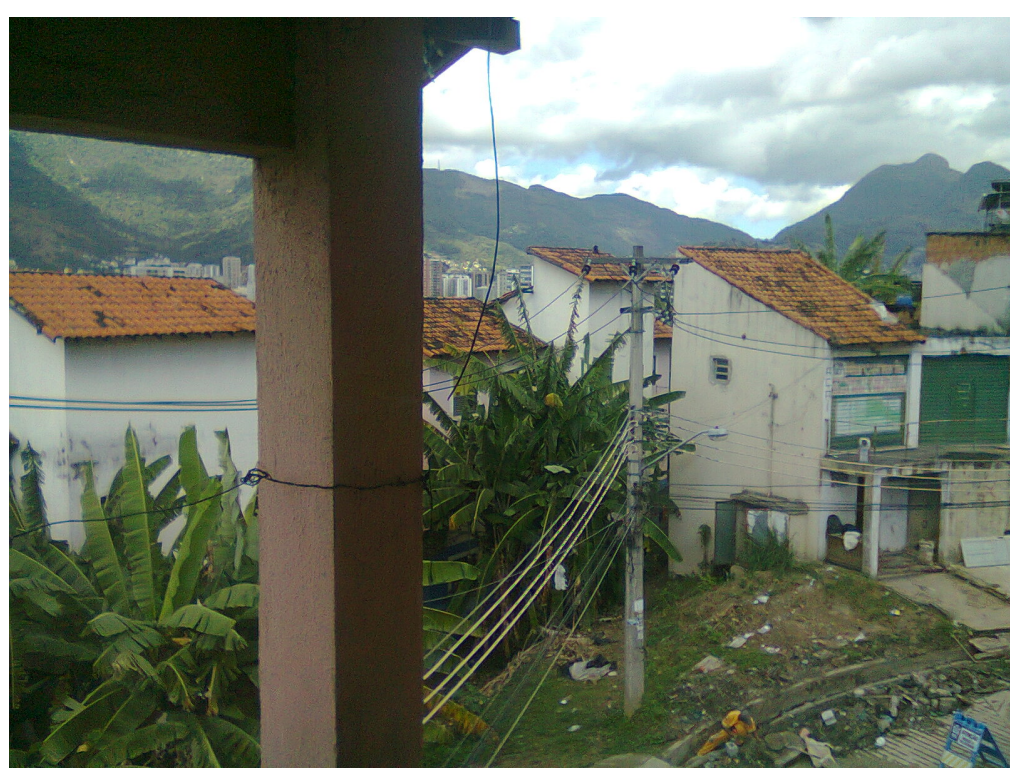

Foto 3: Mangueira, do alto do morro. (foto tirada pela pesquisadora)

\subsubsection{Fluxograma de comunicação na utilização de medicamentos}

Posterior à sistematização do fluxo de informação apresentado no Capítulo 3, e acrescentando-se os dados a partir das entrevistas e questionários realizados, foi elaborado um fluxograma da comunicação na utilização de medicamentos. $\mathrm{O}$ fluxograma sistematiza o fluxo de informação a partir dos possíveis caminhos percorridos pelo paciente na tomada de informação a respeito do tratamento com medicamentos. Utilizou-se, para a construção do fluxograma, os símbolos descritos apresentados na norma ISO 5807 (INTERNATIONAL ORGANIZATION STANDARTIZATION, 1985).

Abaixo são apresentados os símbolos, sua nomenclatura conforme a norma ISO 5807 (1995, p. 17-19, tradução nossa), e uso no fluxograma apresentado a nas páginas seguintes.

conector: para pontos de entrada e saída,

processo: para ação ou tarefa

terminal: para início e fim

decisão: para tomada de decisão

linha: para exposição do fluxo da tarefa apresentada 


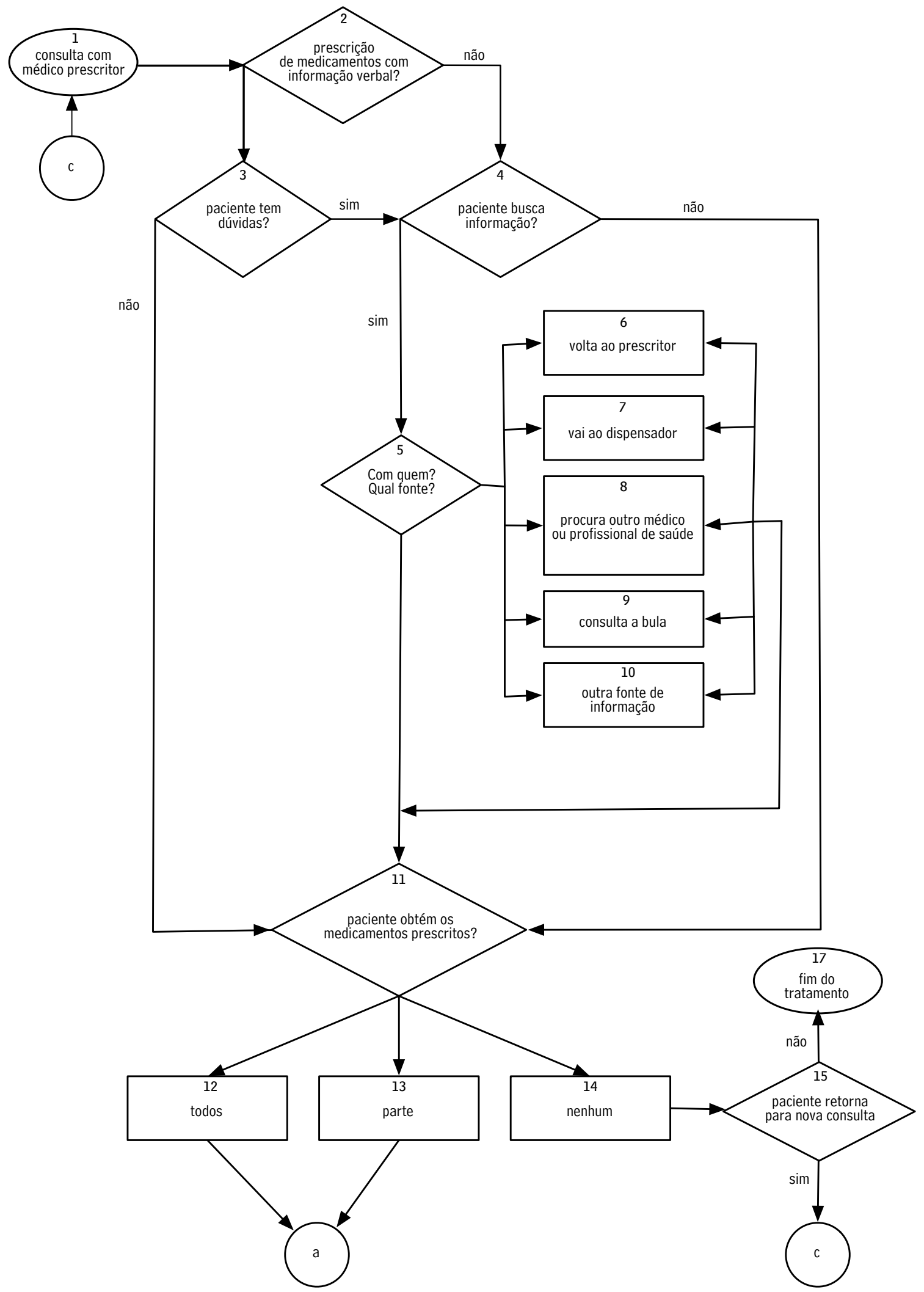

Figura 13: Fluxograma de comunicação na utilização de medicamentos — parte 1/3 


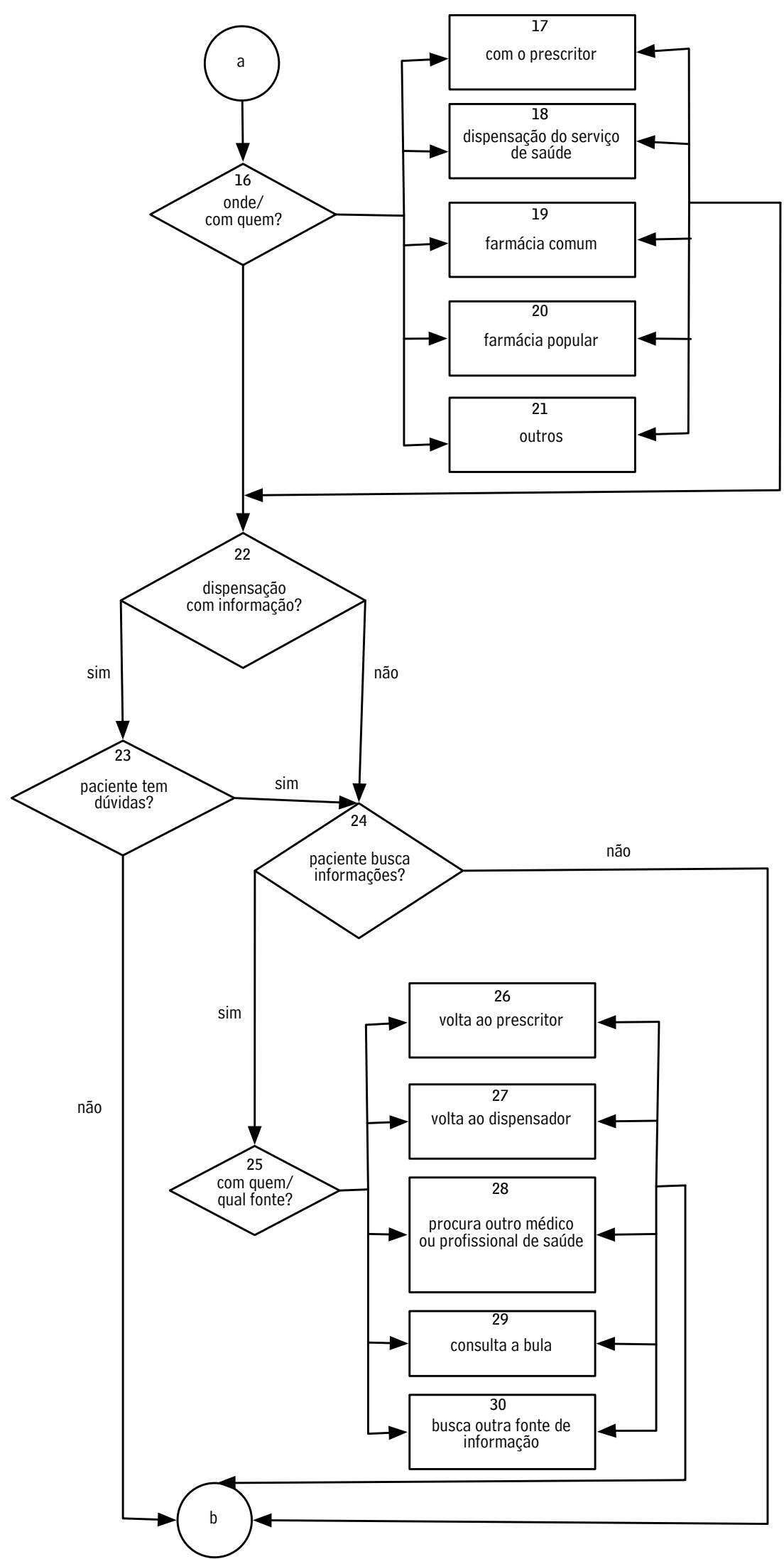

Figura 14: Fluxograma de comunicação na utilização de medicamentos — parte 2/3 


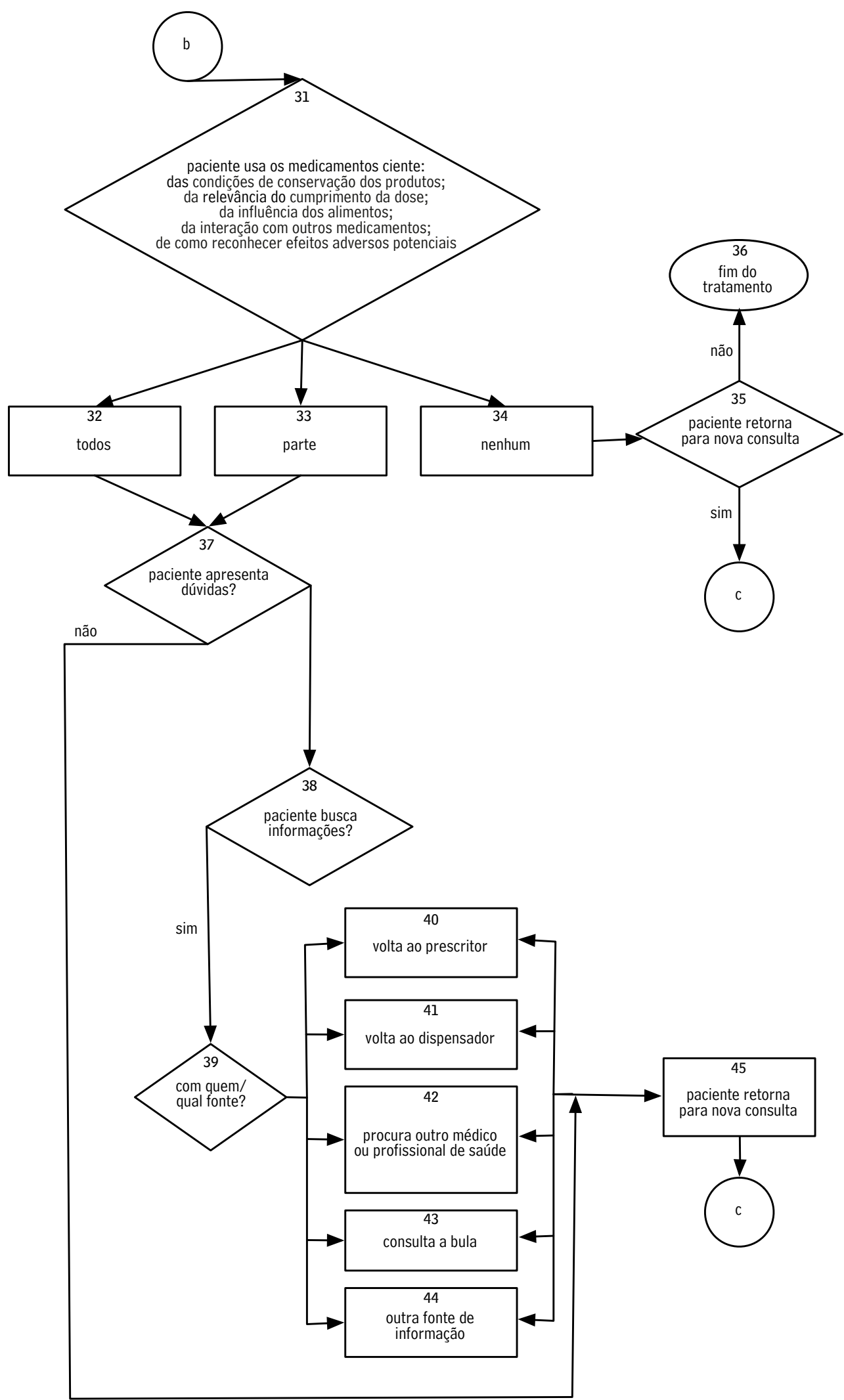

Figura 15: Fluxograma de comunicação na utilização de medicamentos — parte 3/3 


\section{Resultados e discussão}

\subsection{Entrevistas não-diretivas}

\subsubsection{Participantes das entrevistas não-diretivas}

Todos os entrevistados desta etapa da pesquisa foram pacientes / acompanhantes de pacientes cardíacos crônicos atendidos em um hospital público de assistência terciária em saúde ${ }^{26}$ na cidade do Rio de Janeiro. As características sóciodemográficas dos pacientes foram registradas a partir de um formulário realizado ao fim da entrevista não-diretiva. Os dados obtidos são apresentados nos gráficos a seguir.

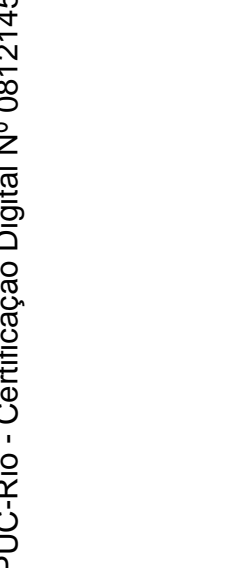

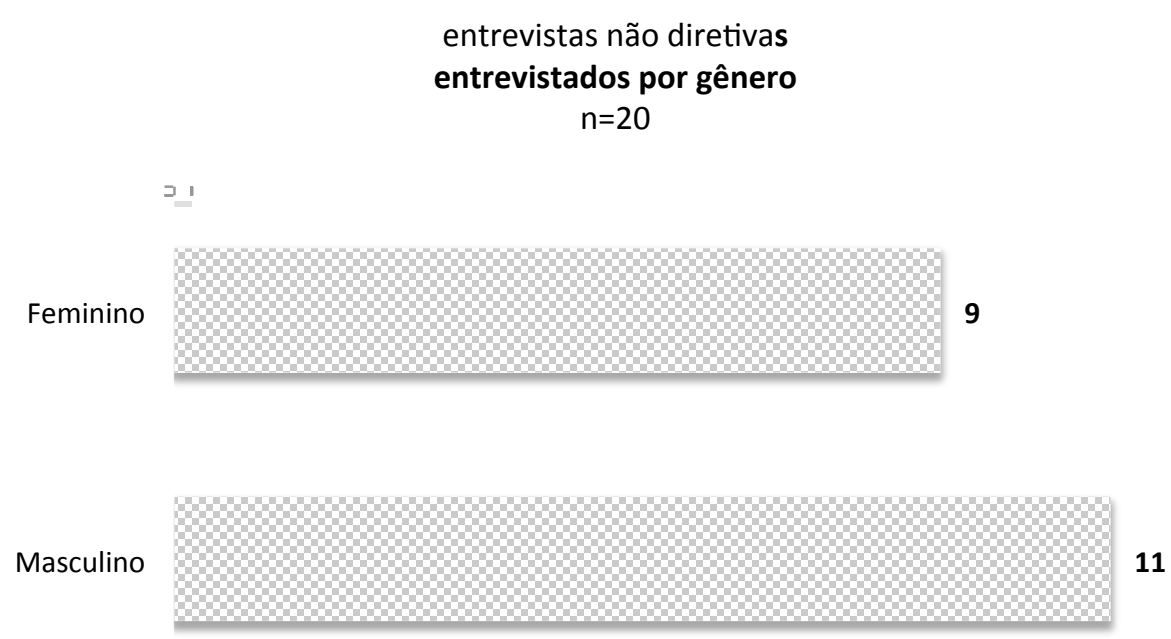

Gráfico 6: Entrevistas não-diretivas - Entrevistados por gênero

26 Atenção terciária em saúde é o nível de atenção constituído por grandes hospitais gerais e especializados, que concentram tecnologia de maior complexidade e de ponta, servindo de referência para os demais programas, sistemas e serviços. Fonte: Descritores em Ciências de Saúde. 
$\square$

entrevistas não diretivas

entrevistados por faixa etária

$n=20$

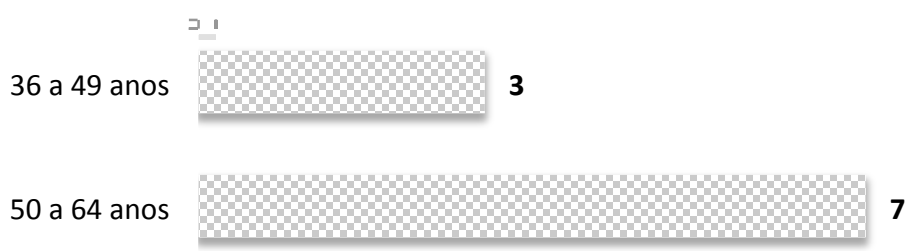

65 a 79 anos

80 anos oumais 1

Gráfico 7: Entrevistas não-diretivas — Entrevistados por faixa etária

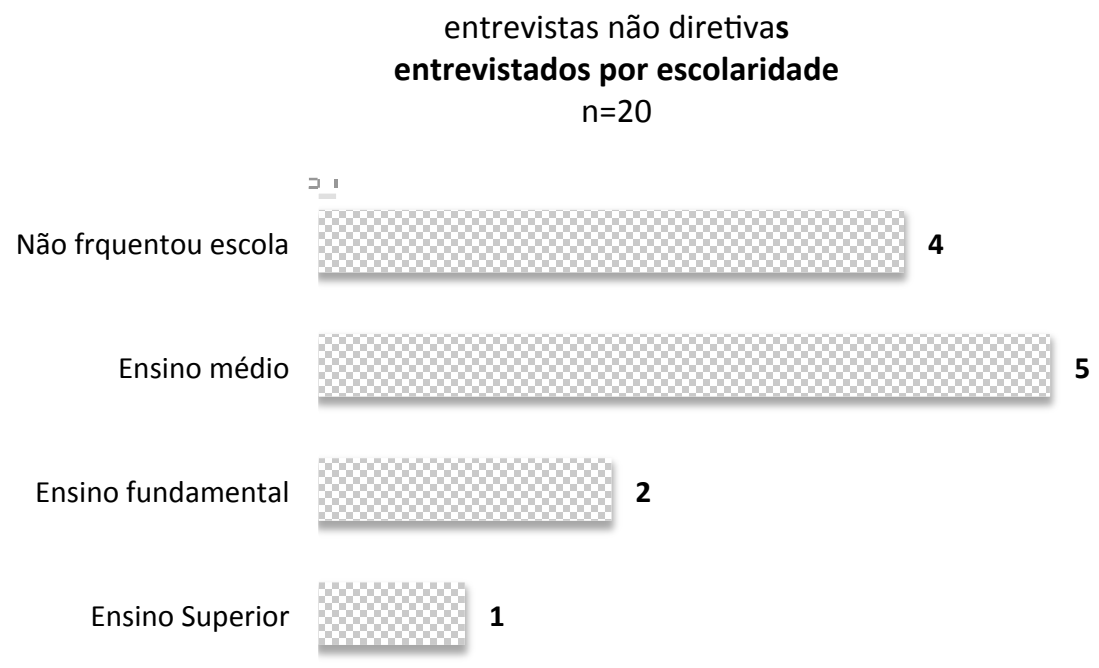

Gráfico 8: Entrevistas não-diretivas — Entrevistados por escolaridade 


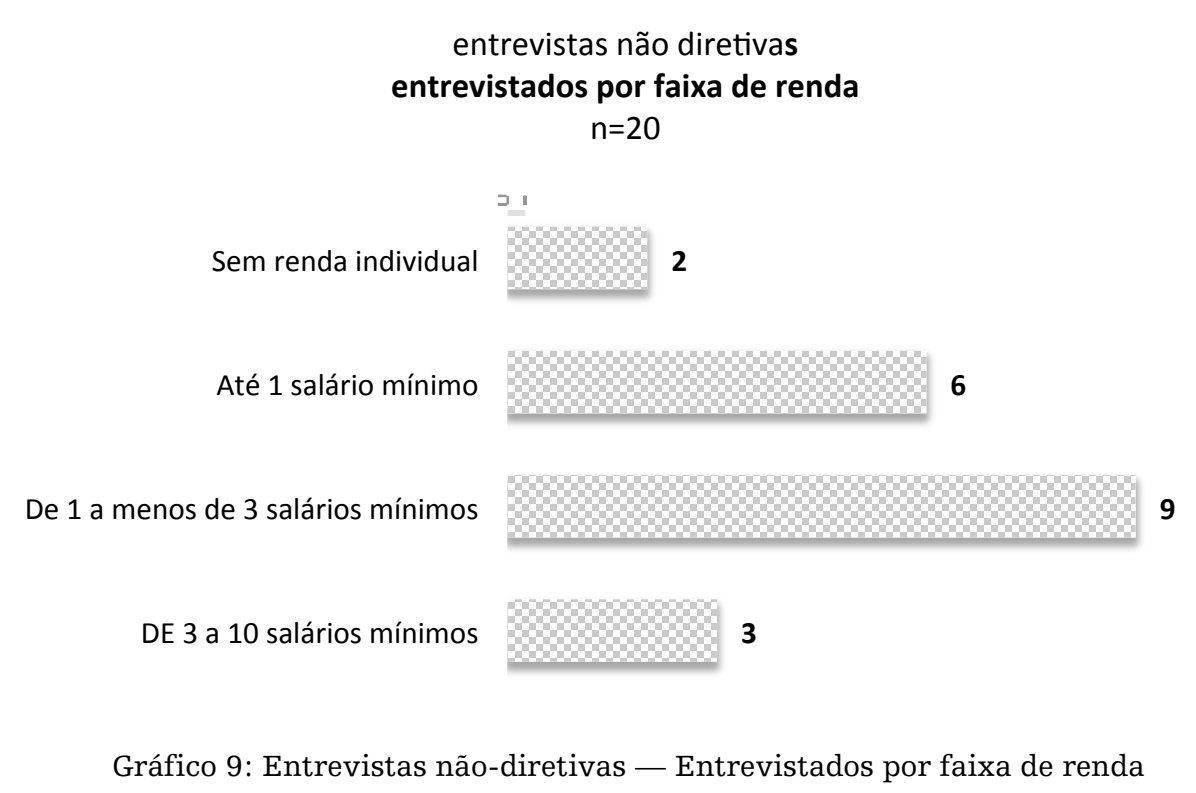

A amostra utilizada foi do tipo não-probabilístico acidental, na qual : "se considera apenas os casos que vão aparecendo e continua-se o processo conforme descrito até que a amostra atinja determinado tamanho" (RUDIO, 1980, p 51).

Os sujeitos selecionados foram todos pacientes em tratamento ambulatorial devido a cardiopatia.

Após a apresentação da pesquisa e da pesquisadora, foi solicitado ao usuário que descrevesse sua rotina de administração de medicamentos e possíveis dificuldades na realização desta tarefa. Ao fim da entrevista sempre era aberto um espaço para o entrevistado expor algo que considerasse importante.

As entrevistas foram gravadas digitalmente e posteriormente transcritas e analisadas segundo o método de análise de conteúdo, descrito por Mucchielli (1982) e Bardin (1979).

Para classificação e tabulação os dos dados foi utilizado o software NVivo9 - QSR International.

\title{
8.1.2 Resultados da análise de conteúdo
}

\author{
8.1.2.1 As pré-categorias definidas ${ }^{27}$
}


O processo de definição de categorias assim como o recorte e categorização dos trechos foi repetido até que o conteúdo analisado ficou categorizado em seis categorias, determinadas conforme os trechos pertinentes à hipótese identificados no corpus. As categorias foram estruturadas a partir da abordagem do paciente frente às dificuldades enfrentadas na utilização dos medicamentos em diferentes fases do uso do medicamento. Ressalta-se que a as etapas apresentadas aqui diferem das apresentadas no capítulo 3_prescrição, dispensação e uso_devido ao foco na presente pesquisa ser a comunicação presente na utilização de medicamentos.

As categorias da análise do conteúdo ficaram estruturadas a partir de uma divisão geral (numeração inicial de 1 a 4): Compreensão do tratamento medicamentoso, Obtenção dos medicamentos, Uso dos medicamentos prescritos e Feedback do tratamento. A partir desta divisão geral ocorre uma segunda divisão, (numeração secundária de 1 a 2), em problemas e dificuldades e métodos e soluções ${ }^{28}$,gerando, cada uma, seis das pré-categorias nas quais os trechos destacados das entrevistas foram codificados.

Abaixo, as seis pré-categorias definidas, conforme sua numeração:

\section{1. compreensão do tratamento medicamentoso prescrito /problemas e dificuldades.}

Nesta categoria foram incluídos trechos das entrevistas relativos a: dúvidas a respeito de qual prescrição seguir; dificuldade na leitura ou compreensão da prescrição escrita ou narrada pelo médico; desconhecimento, dúvida ou imprecisão sobre medicamentos, horário e dose prescritos; desconhecimento do preço do medicamento quando é receitado; insatisfação com a explicação ou prescrição do médico.

\section{2 compreensão do tratamento medicamentoso prescrito / métodos e soluções.}

Nesta subcategoria foram incluídos trechos das entrevistas relativos a solicitação de ajuda do funcionário da farmácia e ajuda de terceiros a respeito de prescrição.

28 Haveriam, portanto, 8 categorias: $1.1,1.2,2.1,2.2,3.1,3.2,4.1$ e 4.2. Mas como não houve relatos de métodos e soluções, a partir no corpus analisado, na Obtenção nos medicamentos ou no Feedback do tratamento, não foram definidas as categorias 2.4 e 4.2 . 


\section{1 obtenção dos medicamentos}

/ problemas e dificuldades

Nesta subcategoria foram incluídos trechos das entrevistas relativos a: problemas relacionados ao custo do medicamento; falta de medicamentos na distribuição gratuita ou farmácia popular e quantidade de medicamentos dispensados inferior ao necessário.

\section{1 administração dos medicamentos I problemas e dificuldades}

Nesta subcategoria foram incluídos trechos das entrevistas relativos a: imprecisão, erro ou dúvida na administração de medicamentos; simplificação da prescrição juntando os horários dos diferentes medicamentos; confusão no uso de porta-comprimidos; dor ou incômodo causado pelo efeito adverso; efeito adverso incompatível com a atividade que vai executar; associação do tamanho do comprimido ao efeito do medicamento; semelhança de cor e forma entre comprimidos; associar a necessidade de continuar o tratamento prescrito à identificação ou não de sintomas da enfermidade; falta de interesse, cuidado ou vontade na administração dos medicamentos.

\section{2 administração dos medicamentos / métodos e soluções}

Nesta subcategoria foram incluídos trechos das entrevistas relativos a: manter a receita ou cópia em local visível para ser consultada; associar a administração dos medicamentos prescritos a alguma atividade da rotina; ajustar compromissos com o horário de tomar os medicamentos, manter os medicamentos em local específico, manter os medicamentos em mais de um local, manter os medicamentos na bolsa ou bolso, manter as cartelas na caixa do medicamento, manter o comprimido no blister até a hora da administração, retirada dos comprimidos das cartelas antecipadamente da cartela; recortar do blister a parte da cartela sem medicamento; identificação do medicamento pela caixa; identificação do medicamento pela cor da cartela; identificação do medicamento pela cor, forma ou tamanho do comprimido; identificação do medicamento pelo odor; identificação do medicamento pela dose; manter sempre uma garrafa de água para tomar o medicamento na rua; associação do horário do medicamento ao intervalo entre os diferentes medicamentos; retirada antecipada das cartelas dos 
medicamento que vão ser tomados da caixa; identificação dos medicamentos pela diferença entre nomes, sem identificar os nomes individualmente.

\section{1 feedback do tratamento / problemas ou dificuldades}

Nesta subcategoria foram incluídos trechos das entrevistas relativos a: dificuldade no acesso ao profissional de saúde; dificuldade de compreensão ou crítica à qualidade da informação dada pelo médico; desacordo ou conflito com a indicação médica; não informação ao médico de impossibilidade, problema ou suspensão do uso dos medicamentos prescritos; insatisfação com o encaminhamento do médico às queixas ou dúvidas apresentadas; dificuldade na leitura e/ou compreensão da bula; dúvidas relacionadas ao tratamento, como efeitos e duração; falta de coordenação de horários de exames e consultas; falta de interesse, cuidado ou vontade na observação do tratamento.

\subsubsection{Análise das codificações segundo a divisão geral}

Foram identificados e codificados nas pré-categorias definidas um total de 236 trechos das entrevistas. A seguir é apresentado o total de codificações considerando-se a divisão geral inicial.

entrevistas não diretivas resultados segundo a divisão geral inicial $n=20$

1. Compreensão do tratamento com medicamentos prescritos 37

2. Obtenção dos medicamentos 18 
Do total codificações, mais da metade foi relativa à administração dos medicamentos, totalizando 131 trechos, seguindo-se de Feedback no tratamento, Compreensão do tratamento medicamentoso prescrito e Obtenção dos medicamentos", respectivamente.

No gráfico a seguir é apresentado, na coluna escura, a soma de todas os trechos codificados nas pré-categorias que apresentavam os problemas $e$ dificuldades descritos pelos pacientes a respeito do tratamento com medicamentos. O número de codificações apresentado representa a soma das codificações nas categorias 1.1 Compreensão do tratamento medicamentoso prescrito / problemas e dificuldades, 2.1 Obtenção dos medicamentos / problemas e dificuldades, 3.1 Administração dos medicamentos / problemas e dificuldades e 4.1 Feedback do tratamento / problemas ou dificuldades.

$\mathrm{Na}$ coluna clara, é apresentada a soma de todos os trechos codificados nas pré-categorias que apresentavam os métodos e soluções descritos pelos pacientes a respeito do tratamento com medicamentos. São elas: 1.2 Compreensão do tratamento medicamentoso prescrito / métodos e soluções, 3.2 Administração dos medicamentos / métodos e soluções.

Gráfico 11: Entrevistas não-diretivas - Total de todas as codificações entre as categorias que apresentavam problemas e dificuldades e. métodos e soluções 
No gráfico abaixo são apresentados o total de codificações dividido entre as categorias. Foram identificadas com barras mais escuras as categorias 1.1, 2.1, 3.1 e 4.1 relativas a problemas e dificuldades, e com barras mais claras as categorias relativas aos métodos e soluções.

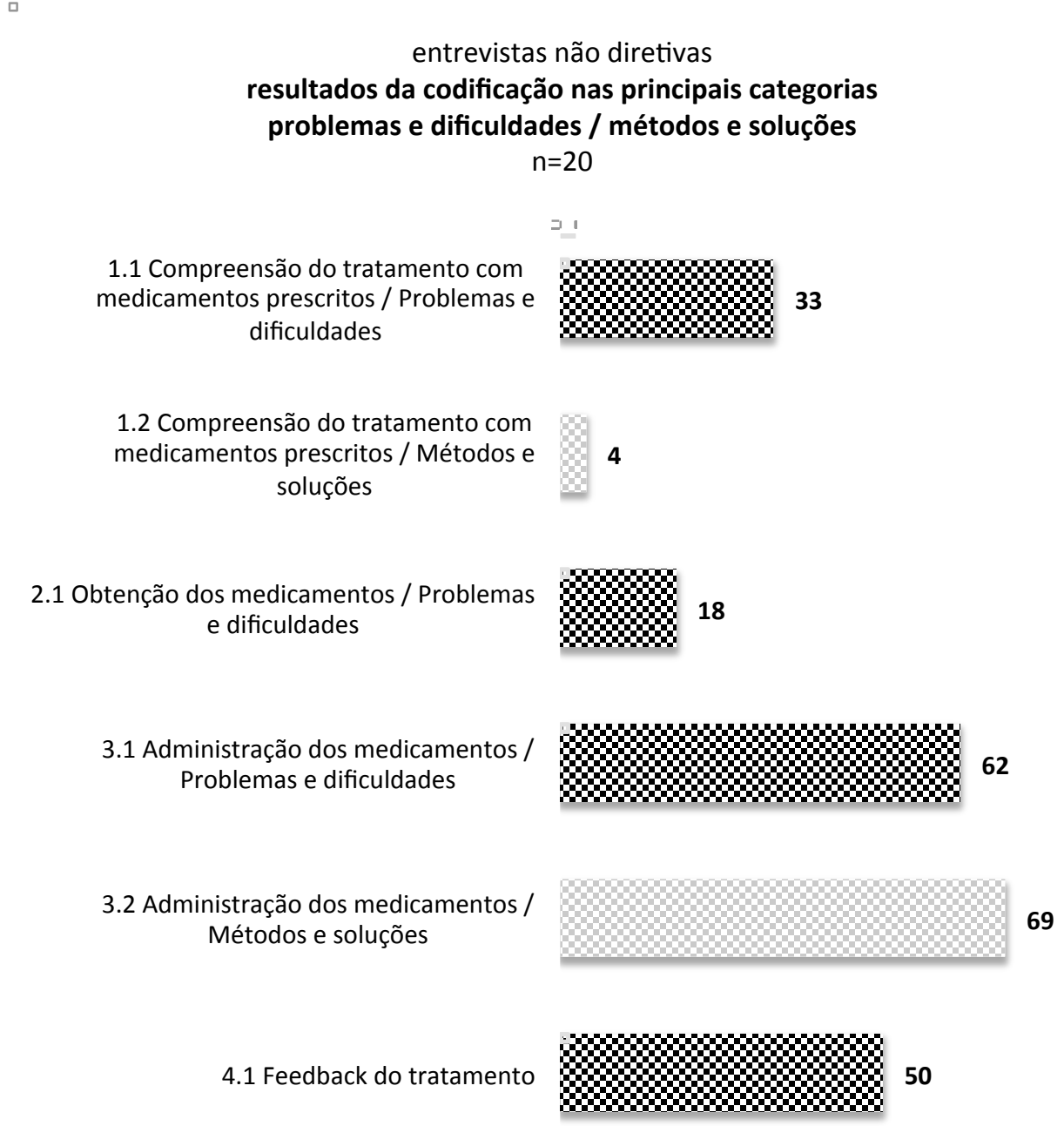

Gráfico 12: Entrevistas não-diretivas - Resultados por subcategoria

Nota-se maior destaque para a categoria 3.2 Administração dos medicamentos / métodos e soluções, que contém 69 do total de 73 métodos ou soluções apresentados pelos usuários, seguido de 1.2 Compreensão do tratamento medicamentoso prescrito. 
Entre os 62 trechos codificados na categoria 3.1 Administração de medicamentos / problemas e dificuldades a maior parte (19 codificações) foi relativa a Imprecisão, erro ou dúvida na administração dos medicamentos. Outros problemas como: associar a necessidade da continuidade do tratamento com medicamentos a percepção de sintomas das enfermidades crônicas, incômodo causado por efeito adverso e falta de interesse, cuidado ou vontade na administração dos medicamentos tiveram um alto numero de codificações - 14, 11 e 10, respectivamente.

A maior parte das imprecisões, erros ou dúvidas dos usuários na administração dos medicamentos (9 itens) foram relatos de simplificação da prescrição ou horários prescritos, feito de forma voluntária pelo usuário. A simplificação consiste em reduzir número de doses, ou mesmo juntar todas as doses do dia numa única tomada de medicamentos. Este procedimento pode acarretar distorções grandes da dose prescrita, como períodos alternados de doses insuficientes e excessivas dos medicamentos prescritos.

\subsubsection{Ajustes nas categorias}

Após a tabulação dos trechos e apresentação dos resultados observou-se que a "compreensão do tratamento medicamentoso prescrito" e "feedback no tratamento" são etapas indissociáveis na utilização dos medicamentos no tratamento de doenças crônicas.

Isto ocorre devido ao caráter longo ou indefinido do tratamento crônico, apresentado no Capítulo 2 da presente pesquisa. Portanto, por ser um tratamento caracterizadamente longo e com retorno periódico ao prescritor, a orientação e feedback ocorrem simultaneamente, a partir da segunda consulta. Foi também alterado o nome da categoria 3, de "administração dos medicamentos" para "uso dos medicamentos", por esta ser a denominação adequada, conforme apresentado no Capítulo 3 desta pesquisa.

Optou-se, portanto, por se trabalhar na análise de conteúdo das entrevistas focadas a partir de três divisões gerais com a seguinte nomenclatura: Compreensão do tratamento medicamentoso prescrito - que engloba tanto a tomada de informação inicial como a tomada de informação nos ciclos subsequentes de utilização de medicamentos —, Obtenção dos Medicamentos e Uso dos medicamentos. 


\subsection{Questionários}

\subsubsection{Participantes dos questionários}

A amostra utilizada foi do tipo não-probabilístico acidental, conforme descrito por Rudio (1980, p.51).

Os sujeitos selecionados foram 35 pacientes cardiopatas, sendo que a maior parte -25 - foram mulheres. As faixas etárias variaram entre 36 e mais de 80 anos, sendo a maioria dos entrevistados mulheres entre 50 e 79 anos.

Quanto à renda, a grande maioria recebia até 3 salários mínimos.

Com relação à escolaridade houve uma distribuição em todas as categorias, mas com peso maior nas faixas de escolaridade mais baixas.

A respeito do tipo de serviço de saúde que o paciente utiliza, houve uma falha na aplicação do questionário, e 7 deles ficaram sem marcação de resposta, mas dos 28 respondidos, pode-se notar a predominância de pacientes atendidos no serviço público.

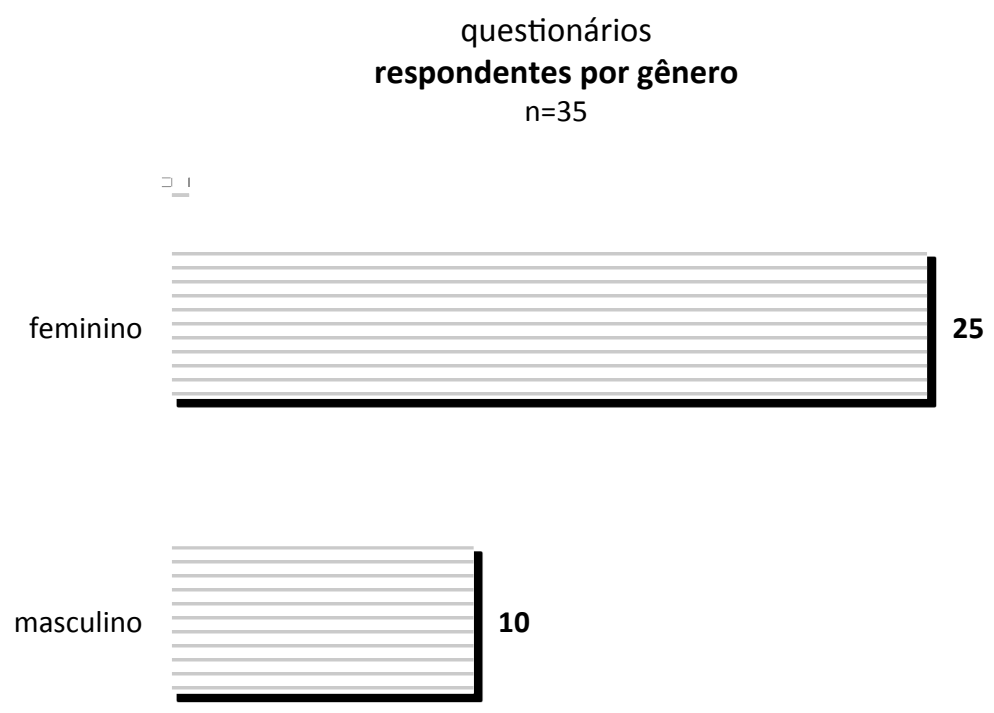

Gráfico 13: Questionário — Respondentes por gênero 
questionários

respondentes por idade

$\mathrm{n}=35$

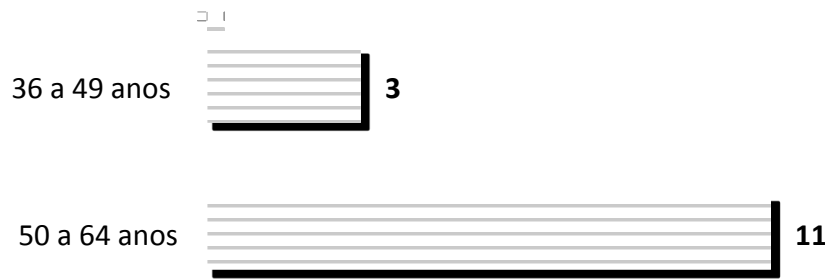

65 a 79 anos

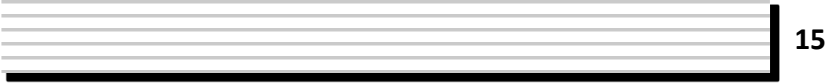

mais de 80 anos

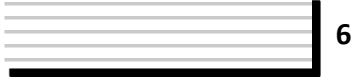

Gráfico 14 : Questionários — Respondentes por faixa etária

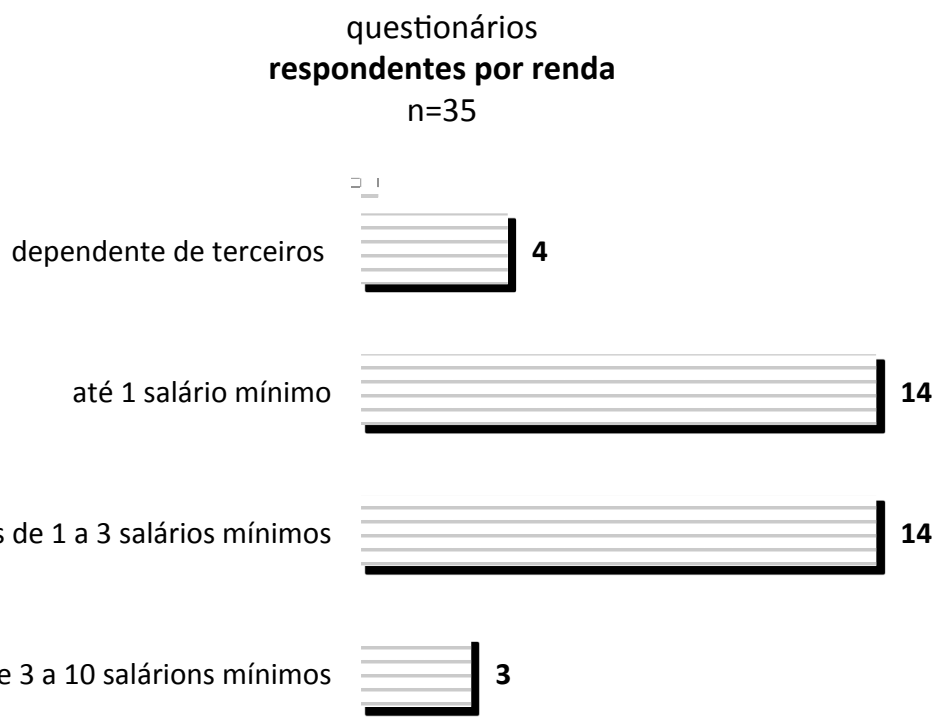

Gráfico 15: Questionários — Respondentes por faixa de renda 
questionários

\section{respondentes por escolaridade}

$$
\mathrm{n}=35
$$

não frequentou escola

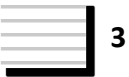

ensino fundamental

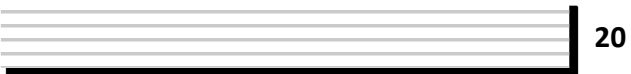

ensino médio

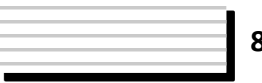

ensino superior completo

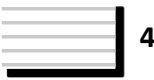

Gráfico 16: Questionários - Respondentes por escolaridade

questionários

respondentes pelo tempo que toma medicamentos

para doença crônica

$\mathrm{n}=35$

de 1 a menos de 5 anos

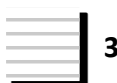

5 anos ou mais

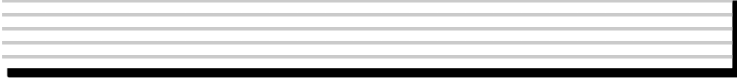

Gráfico 17: Questionários - Respondentes pelo tempo que tomam medicamentos para doença crônica 
questionários

respondentes por tipo de serviço de saúde que utiliza $n=35$

público

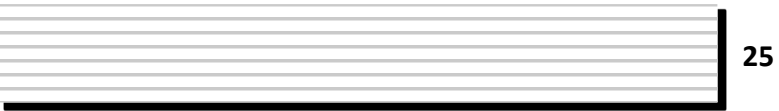

particular

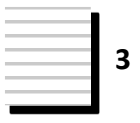

sem resposta

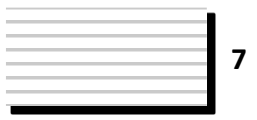

Gráfico 18: Questionários: — Respondentes por tipo de serviço de saúde que utiliza

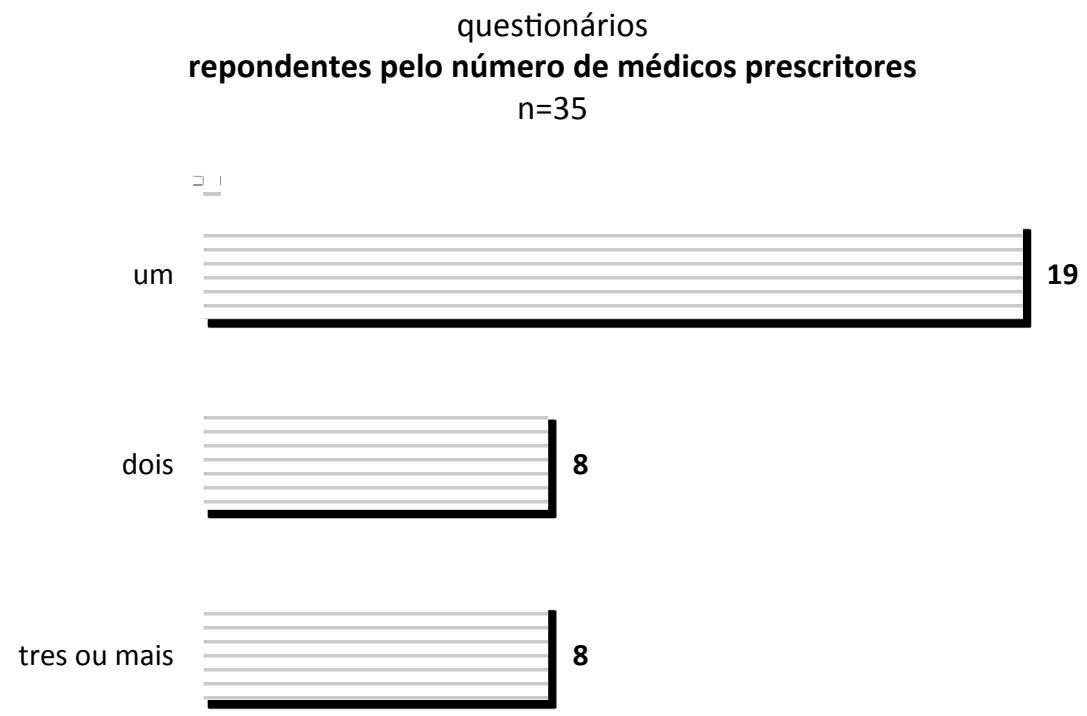

Gráfico 19: Questionário - Respondentes pelo número de médicos prescritores 


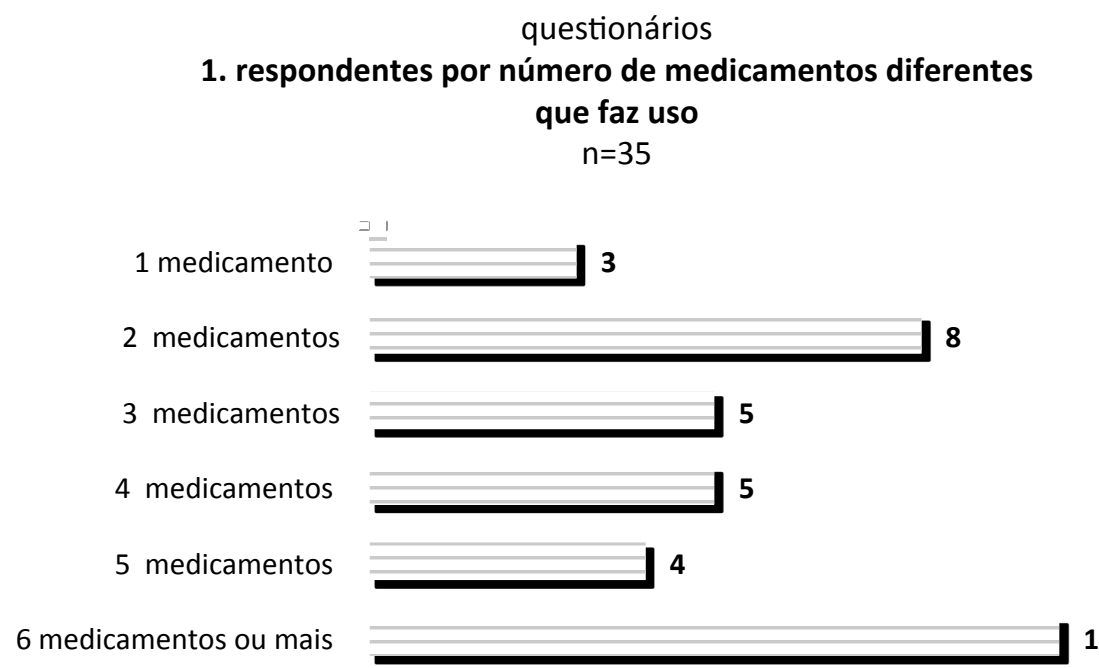

Gráfico 20: Questionários — Respondentes por número de medicamentos diferentes que toma

No resultado à resposta 1 , foram incluídos todos os medicamentos descritos pelo paciente a partir da pergunta: Quais medicamentos o Sr. (a) toma, e a que horas? Foram considerados tanto os medicamentos de uso constante quanto os de uso ocasional. Isto se deu pelo fato do paciente ter que administrar, ainda que ocasionalmente, todos os medicamentos em um dia.

\subsubsection{Resultados dos questionários}

Nas respostas das perguntas de 2 a 6 , relativas à adesão ao tratamento, observa-se um número bastante alto de respostas indicando que o paciente segue o tratamento como prescrito.

Entretanto, observou-se que esses dados poderiam não corresponder à atitude real do entrevistado, uma vez que havia, muitas vezes, dificuldade do respondente em verbalizar sua prescrição quando longe de casa.

A observação desta dificuldade, somada à ao fato dos pacientes entrevistados se referirem à residência como local de referência da utilização dos medicamentos, direcionou que a próxima etapa da pesquisa - entrevistas focadas — fosse realizada nas residências dos usuários. 
2. costuma seguir exatamente o que está na receita? $n=35$

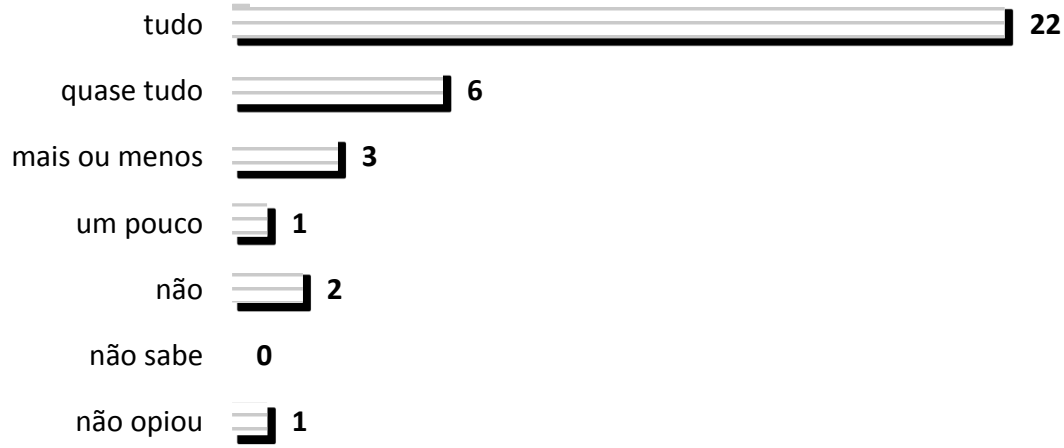

Gráfico 21: : Questionários — Respostas à pergunta 2

3. se passa do horário de tomar o meicamento, como faz? $n=35$

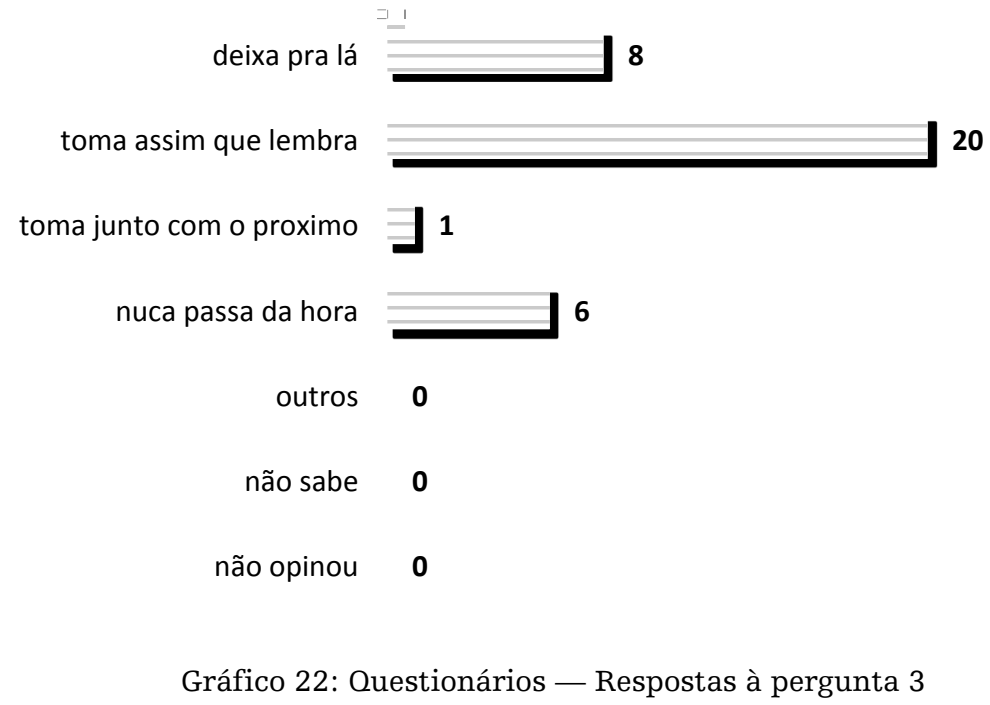


4. já deixou de comprar algum medicamento prescrito? $n=35$

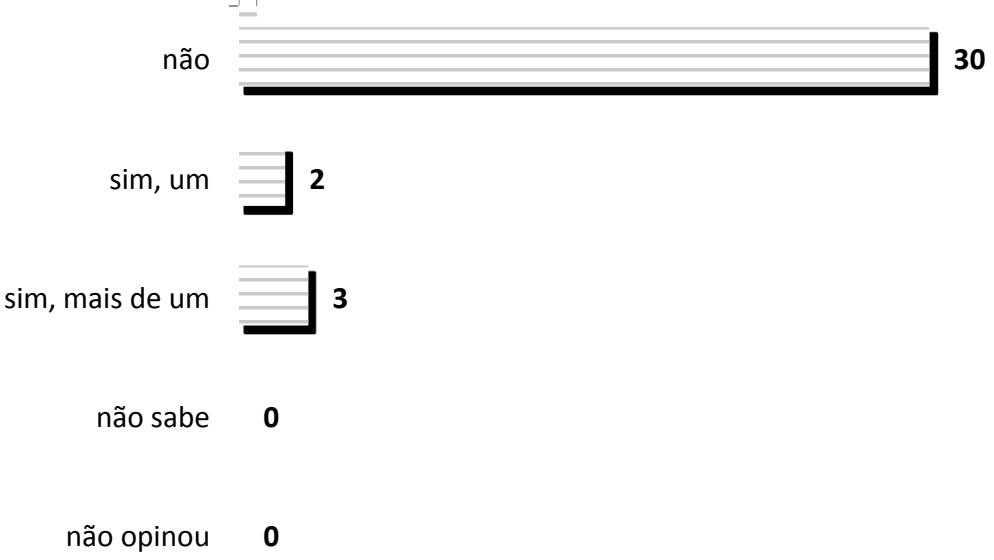

Gráfico 23: Questionários - Respostas à pergunta 4

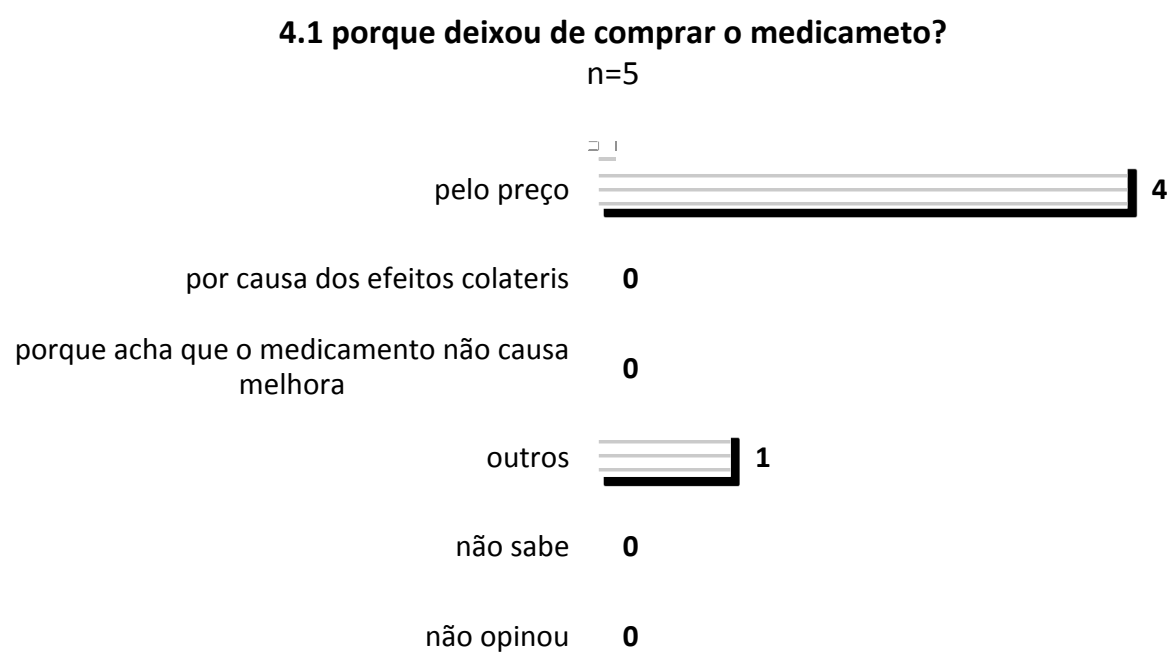

Gráfico 24: Questionários - Respostas à pergunta 4.1 
5. já deixou de tomar algum medicamento prescrito devido a incômodo? $\mathrm{n}=35$

sim, mais de $1 \geq 2$

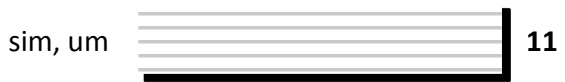

não

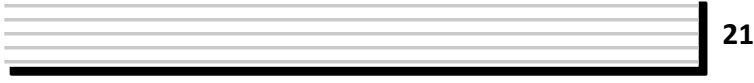

não opinou 1

Gráfico 25: Questionários — Respostas à pergunta 5

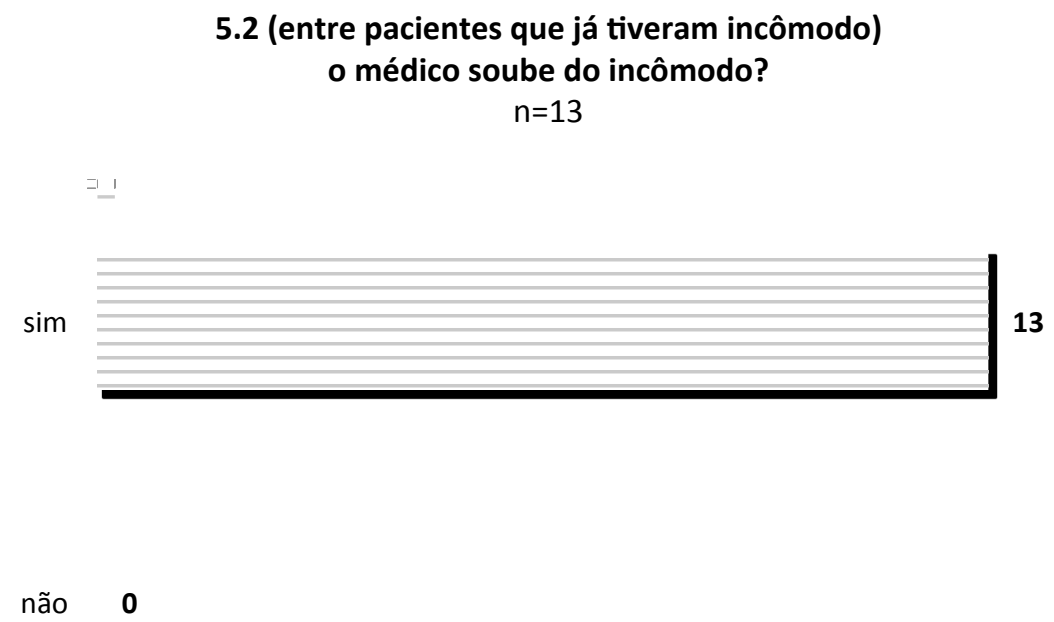

Gráfico 26: Questionários — Respostas à pergunta 5.2 


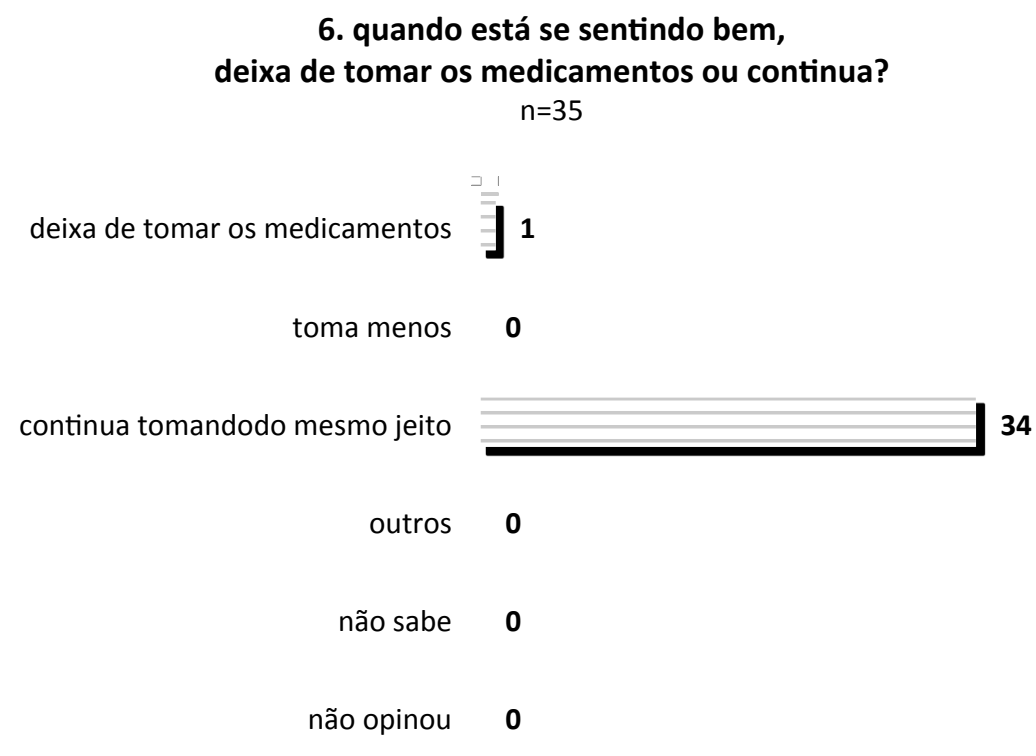

Gráfico 27: Questionários — Respostas à pergunta 6

As perguntas a seguir correspondem a elementos objetivos da autoadministração de medicamentos, chamando a atenção para o cotidiano desta tarefa na qual o paciente - às vezes de maneira simples, como tendo uma caixa especial ou um potinho para guardar os medicamentos - se organiza e realiza essa tarefa.

Todos tinham um lugar especial para a armazenagem dos medicamentos, e 3 deles ainda guardam na caixa onde recebiam os medicamentos da prefeitura, quando esses eram entregues diretamente na casa dos pacientes. A manutenção da caixa para esta finalidade apresenta uma interação do sistema de saúde com o cotidiano do paciente. 
7. Em casa, onde costuma gurdar medicamentos?

$$
n=35
$$

caixinha, sacola, cestinha, gaveta, ou outro local específico
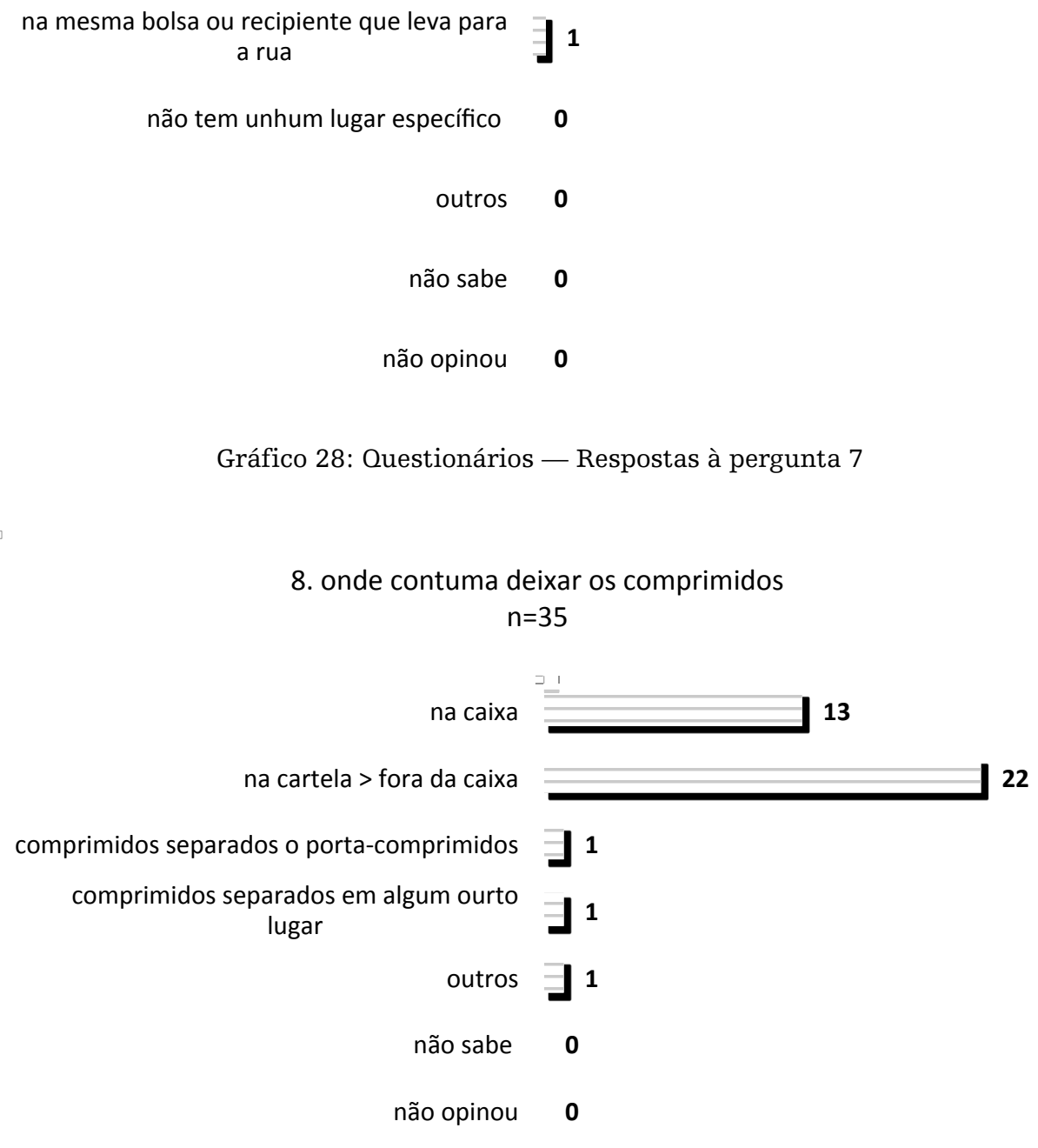

Gráfico 29: Questionários — Respostas à pergunta 8

Esta pergunta tem um número de respostas maior do que o número de respondentes porque alguns respondentes deixam os medicamentos na caixa, quando recebidos na caixa, mas os medicamentos distribuídos nas unidades públicas de saúde são dispensados nas cartelas. 10 respondentes comentaram o recebimento do medicamento na cartela ao complementar a resposta dada. Houve imprecisão na redação da pergunta, que se referia ao comprimido. Pelo fato da pesquisadora ter realizado a aplicação do questionário, tornou-se viável a complementação da pergunta de forma a esclarecê-la. 


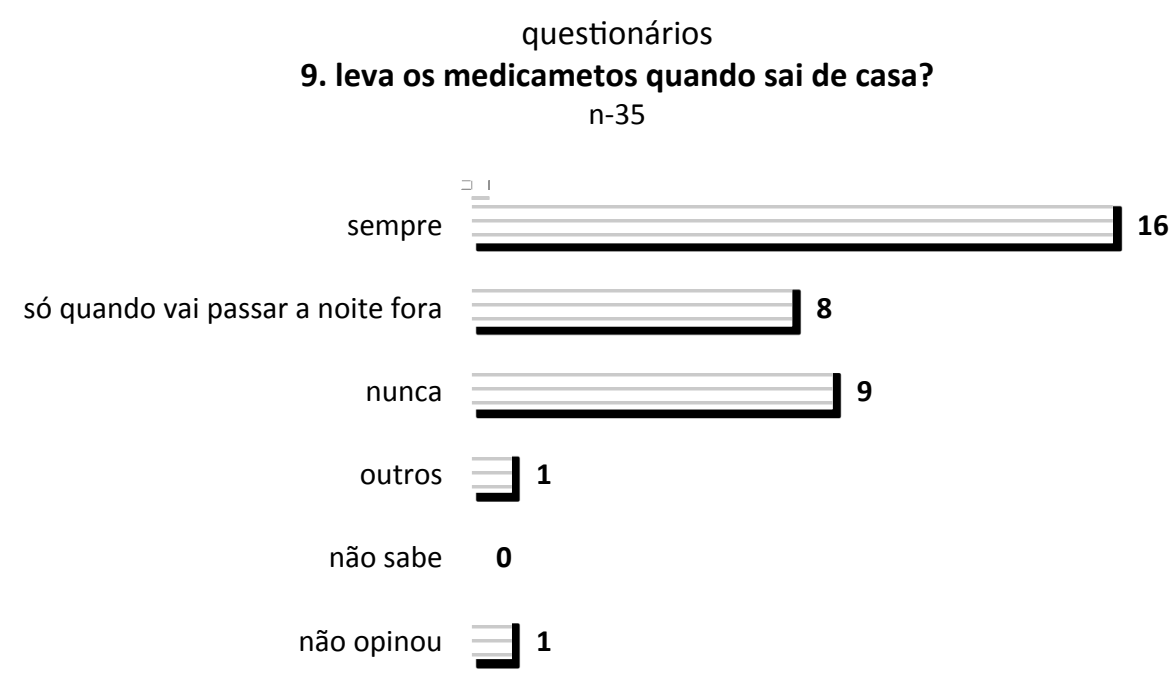

Gráfico 30: Questionários — Respostas à pergunta 9

questionários

9.1 onde costuma levar os medicamentos quando sai de casa?

(mais de uma resposta possível por entrevistado)

$n=35$

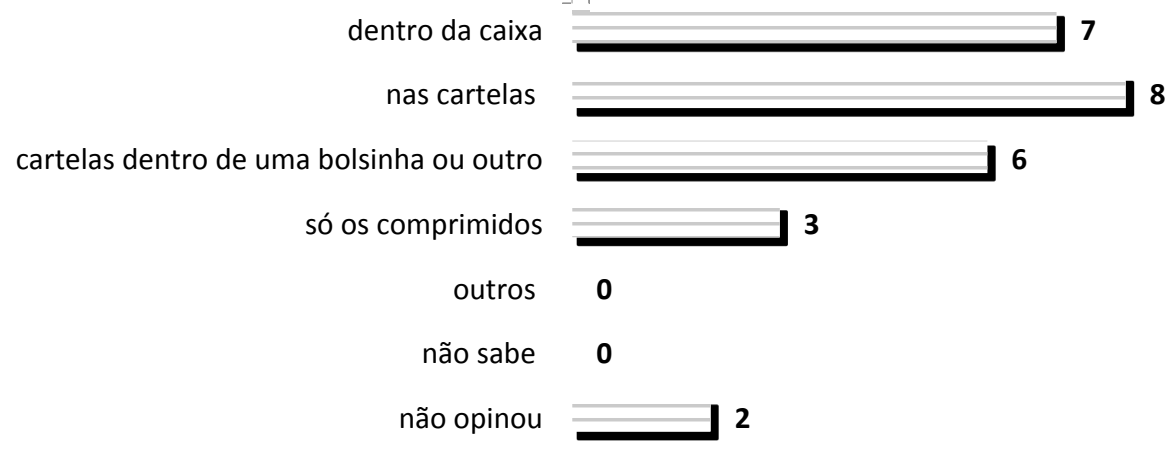

Gráfico 31: Questionários - Respostas à pergunta 9.1

Analisando-se as respostas à próxima pergunta observa-se que a cartela representa um elemento importante na identificação do medicamento. O nome do medicamento é um fator de informação importante, mas outros elementos gráficos presentes na cartela, somados, representam 27 respostas. As respostas no item Outros foram: forma do nome, e quantidade de comprimidos na cartela. É importante ressaltar que a resposta "forma do nome" é diferente da resposta "nome na cartela". A primeira, dada por uma entrevistada sem escolaridade, significa que é a forma da palavra, e não sua leitura, que é o fator de identificação. 


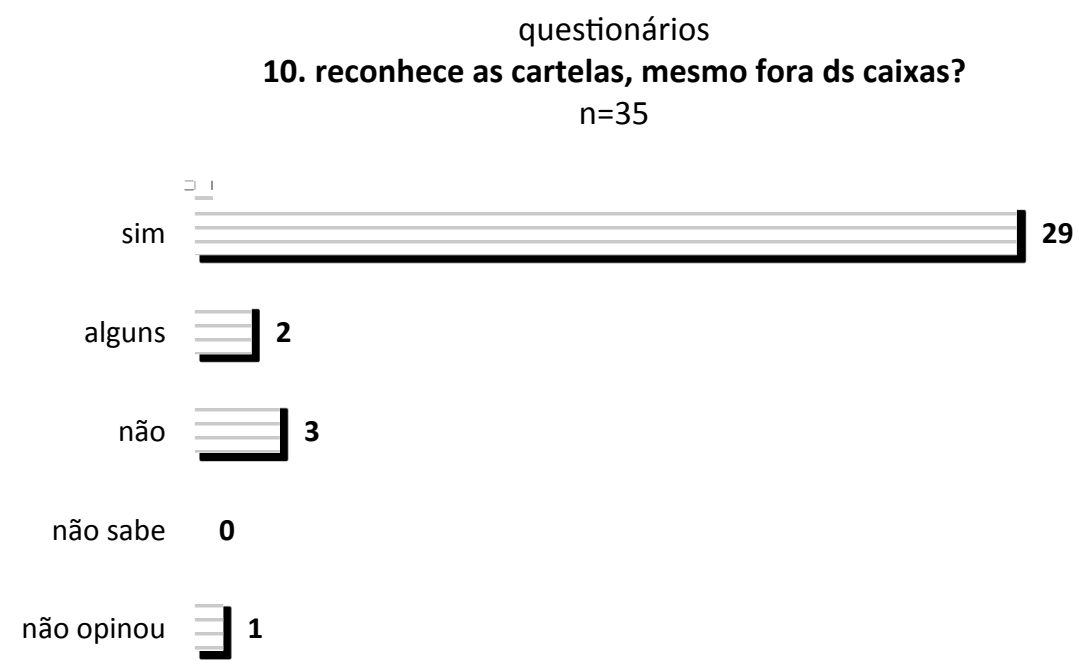

Gráfico 32: Questionários — Respostas à pergunta 10

\section{questionário \\ 10.1 o que tem de diferete na cartela que faz com que o usuário a identifique} $\mathrm{n}=31$

(entre os respondtes que idetificam as diferetes cartelas, mais de uma resposta possível por entrevistado)

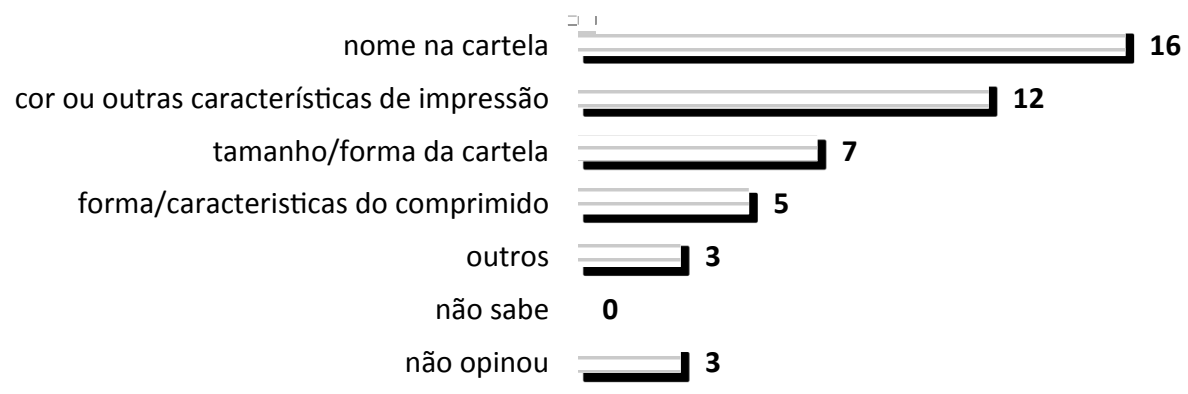

Gráfico 33: Questionários — Respostas à pergunta 10.1 
Nas respostas a seguir observa-se que o comprimido, mesmo dentro da cartela, é um forte elemento de identificação do medicamento. As respostas seguintes mostram que dos 35 entrevistados, 25 relatam identificar os comprimidos dos diferentes medicamentos administrados e que o tamanho e a cor são os principais fatores de identificação dos medicamentos. Chama a atenção que a ranhura presente no medicamento para marcar sua divisão tenha sido apresentada como fator de identificação do medicamento em 5 respostas. $\mathrm{Na}$ categoria "outros" foram apresentados como elementos de identificação: o gosto, um número - possivelmente identificando a dose — impresso no comprimido.

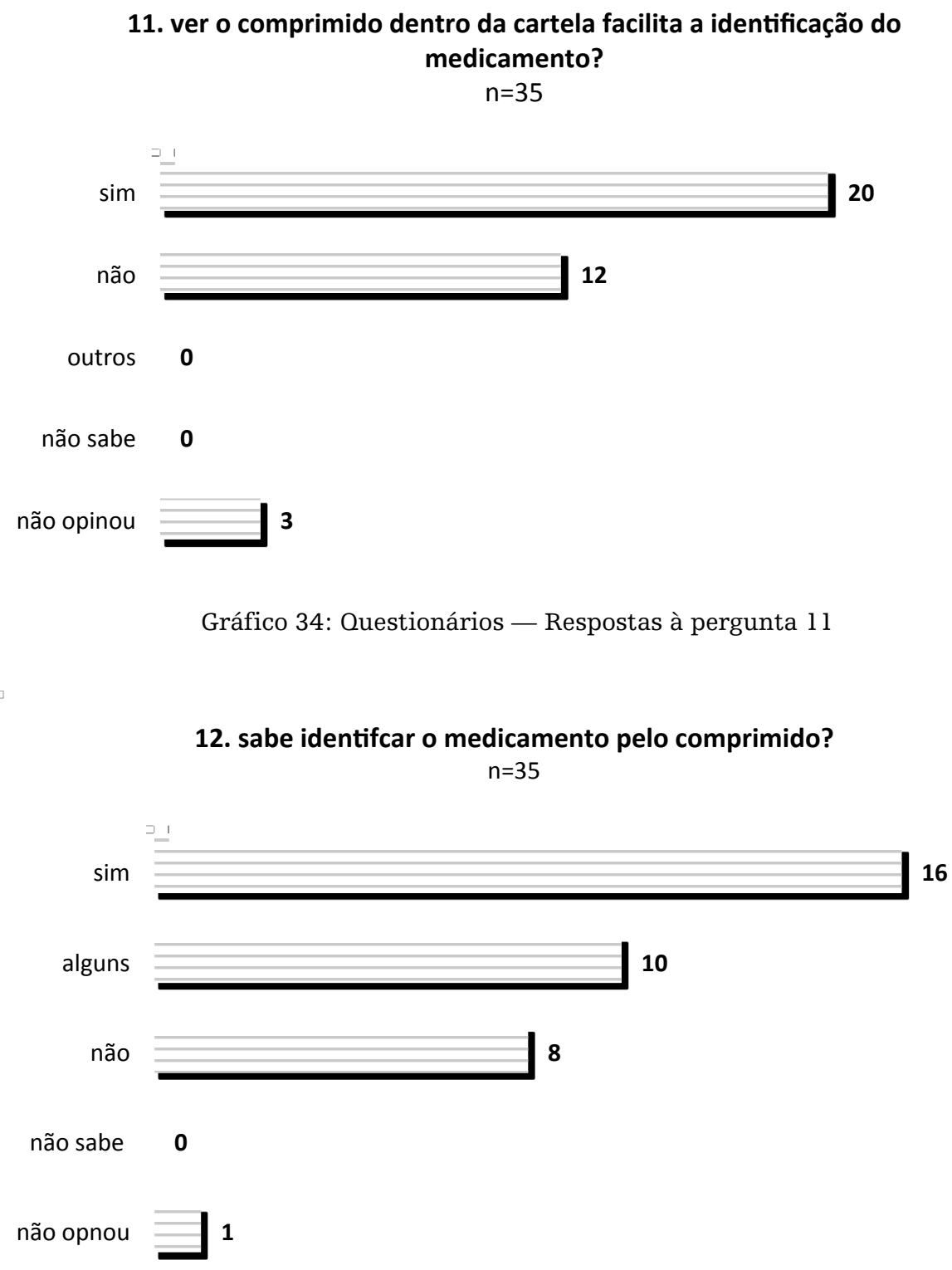

Gráfico 35: Questionários — Respostas à pergunta 12 


\section{(respondentes que identificam \\ pelo menos um dos medicmento pelo comprimido) \\ 12.1 como idetifica? \\ $\mathrm{n}=35$}

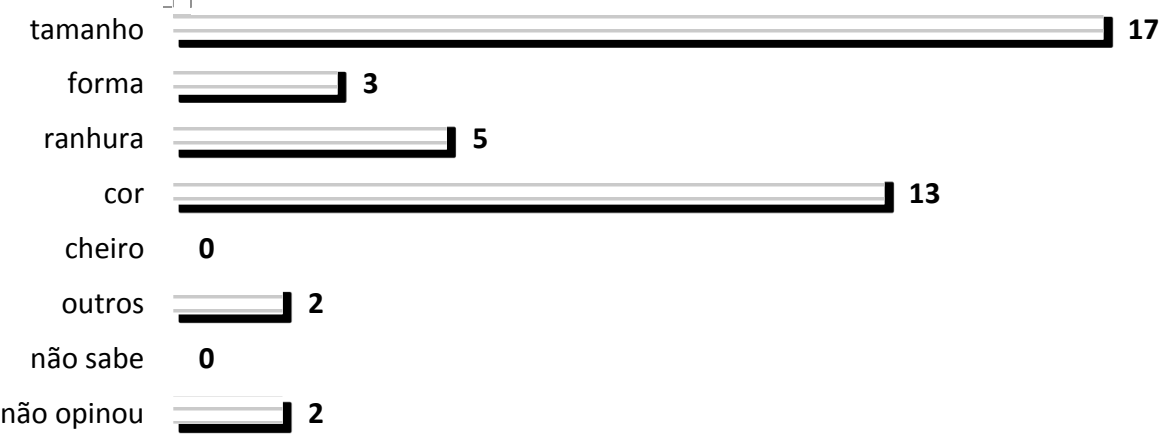

Gráfico 36: Questionários — Respostas à pergunta 12.1

A pergunta 13 baseou-se na observação, durante a etapa piloto dos questionários, que os pacientes costumavam deixar a receita médica em local visível para eventualmente consultá-la $\mathrm{O}$ grande número de respostas na opção "outros" indica que houve falha na escolha das opções de respostas apresentadas no questionário.

Torna-se importante, então, apresentar os locais apresentados nesta opção. Dentre os outros locais descritos pelos respondentes estão: junto com os medicamentos (por 9 respondentes); e na bolsa ou junto com documentos (por 5 respondentes). Essas respostas indicam a relevância da receita médica na rotina dos pacientes. Observa-se que o número de respostas à pergunta 13 excede o número de respondentes, pois um entrevistado relatou guardar a receita médica em uma pasta, mas também ter uma cópia fixada na porta da geladeira. 


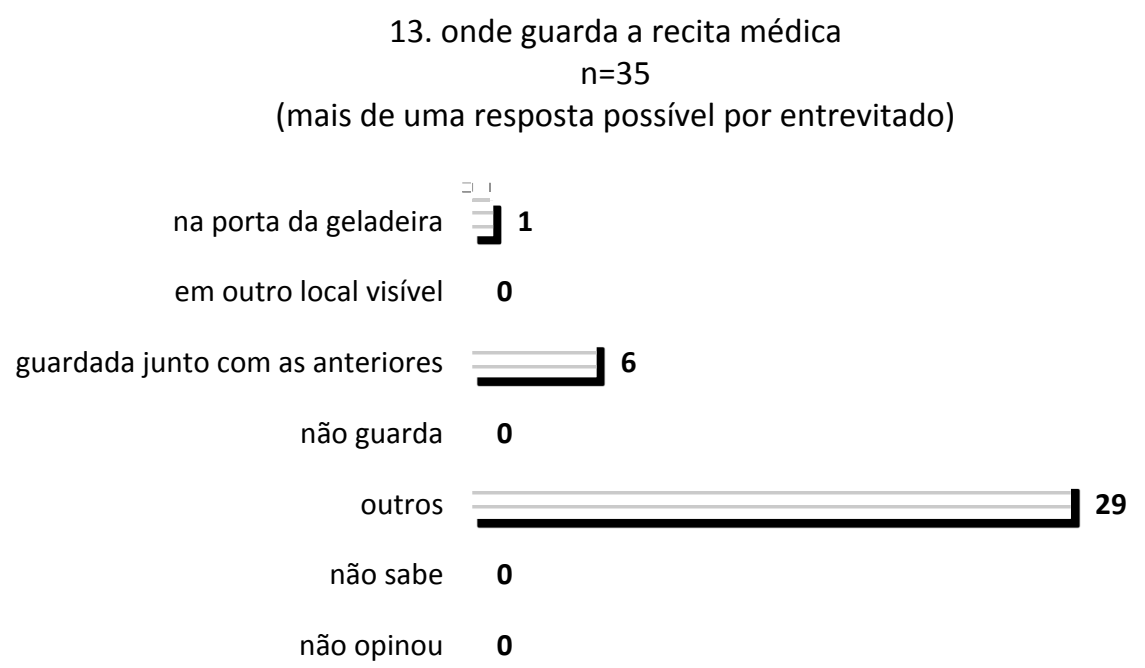

Gráfico 37: Questionários - Respostas à pergunta 13.

Com relação ao uso da caixinha de porta-comprimidos, parte dos respondentes não a conhece, mas a maioria conhece e não usa. A maioria das respostas entraram na categoria "outros". Apenas um respondente afirmou que gostaria de usar. Dois se referiram ao medicamento estar mais seguro na embalagem, pois acreditam que o uso da caixa seja confuso; um afirmou que, ao invés de serem organizados pelos dias das semanas, os compartimentos deveriam ser rotulados pelo nome do medicamento e outro afirmou que não usa porque seriam dois trabalhos - tirar da embalagem original, e depois ter que tirar da caixinha para tomar.

14. conhece a caixinha porta-comprimidos?

$\mathrm{n}=35$

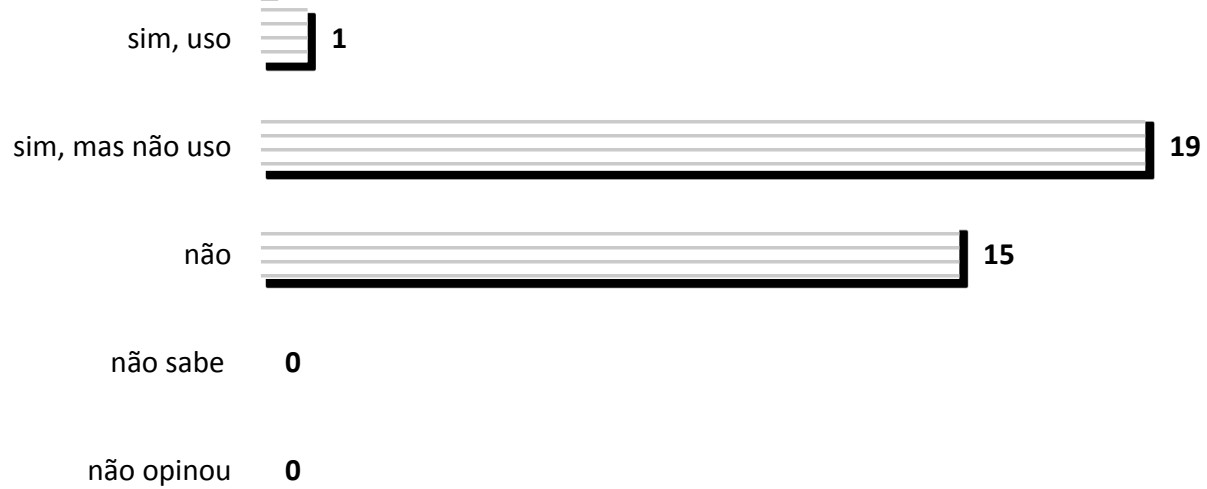

Gráfico 38: Questionários - Resposta à pergunta 14 


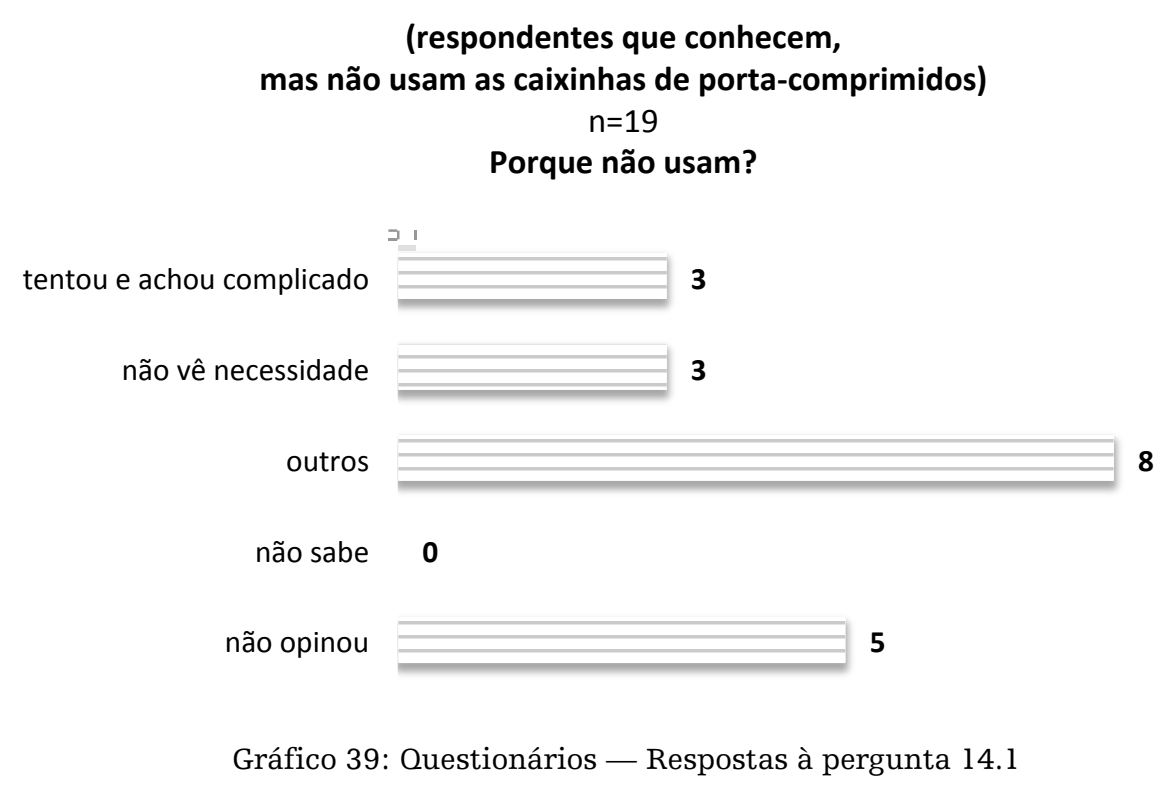

Nas respostas à pergunta 15 , relativa ao nível de compreensão dos usuários das informações presentes na receita médica, 15 dos 35 entrevistados afirmaram não entender. Observa-se ainda que, nos entrevistados que responderam "sim" foram: "Sim, alguma coisa"; "Às vezes sim"; "Sim, porque quando não entendo falo com meu filho"; "Sim, mas depende da letra do médico" e "Sim, quando é escrita no computador". Os comentários indicam que os resultados quantitativos a esta perguntam não representam com clareza a opinião doa entrevistados a este respeito.

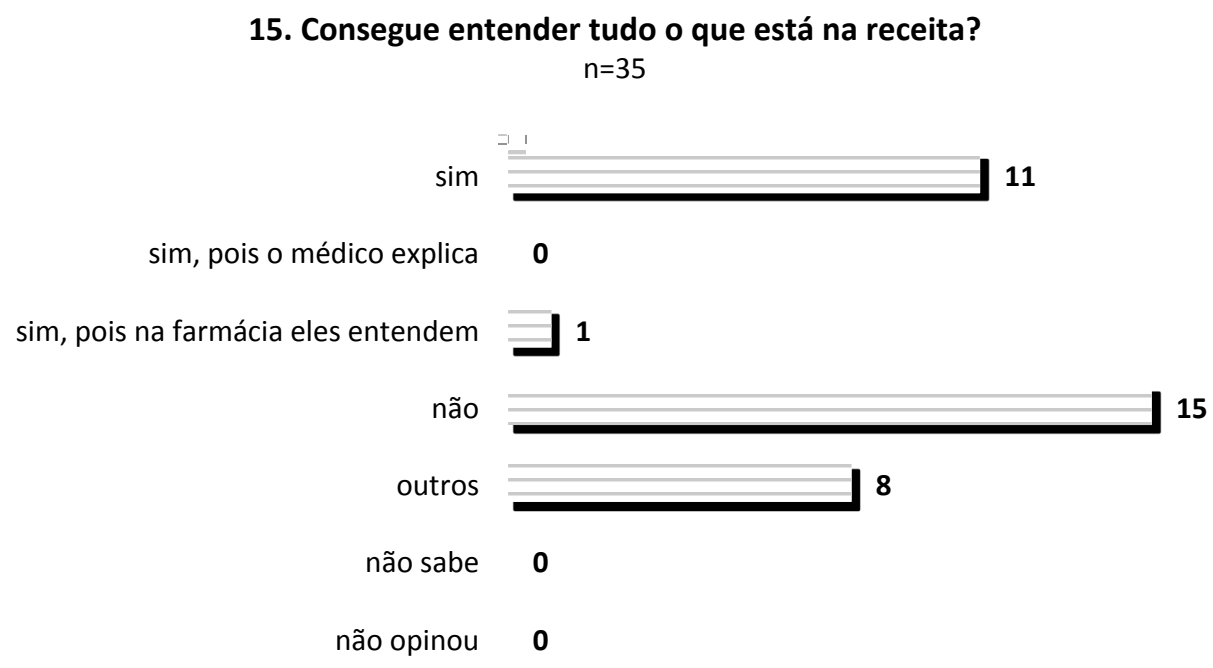

Gráfico 40: Questionários — Respostas à pergunta 15 
A pergunta 16 apresenta uma série de etapas da comunicação/administração dos medicamentos. Foi solicitado aos respondentes que indicassem o nível de dificuldade presenciados nas diferentes etapas. Diferente das demais perguntas do questionário, quando as respostas espontâneas e marcadas pela entrevistadora em uma das opções de resposta presentes no questionário, as opções "fácil, depende e difícil" eram apresentadas ao entrevistado pra sua escolha.

O item considerado mais fácil foi "identificar o medicamento", seguido de "entender a que horas deve tomar o medicamento", e "lembrar a hora de tomar o medicamento". Todos relativos a etapas da administração dos medicamentos.

Alguns respondentes não se posicionaram a respeito de alguns itens desta pergunta, pois ocorre que outra pessoa, em determinado momento, desempenhe alguma das funções. Pode-se citar como exemplo, a esposa ou a filha lembrarem a hora de tomar o medicamento.

Somando-se os itens "difícil" e "depende", a etapa que apresentou maior dificuldade foi entender o que é escrito pelo prescritor. 
16. opinião dos respndente relativs ao nível de dificuldade nas diferentes etapas da administração dos medicamentos $n=35$

entender oque o médico diz

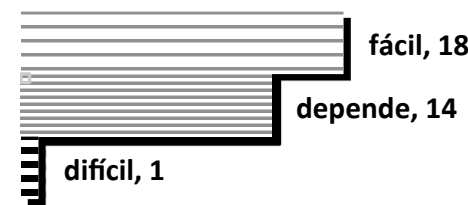

entender o que o médico escreve

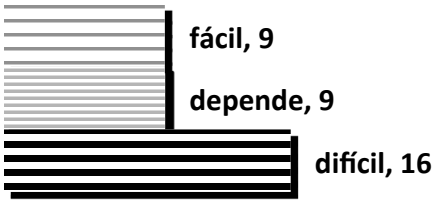

comprar os remédios
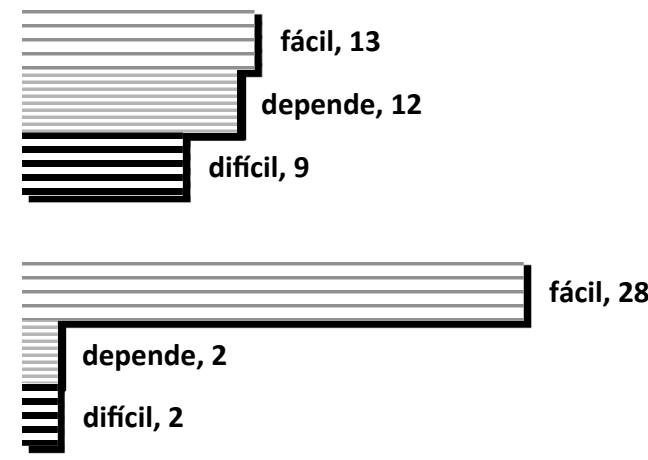

lembrar a hora de tomar os remédios

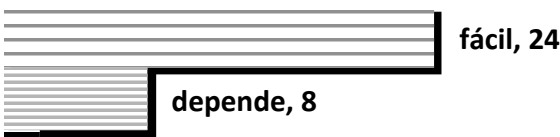

difícil, 2

entender qual remédio é qual na hora de tomar

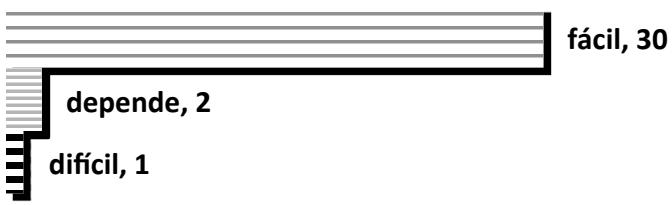

encontrar o médico em caso de dúvida
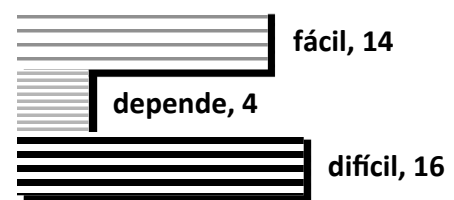

fácil, 22

explicar pro médico o que se passa

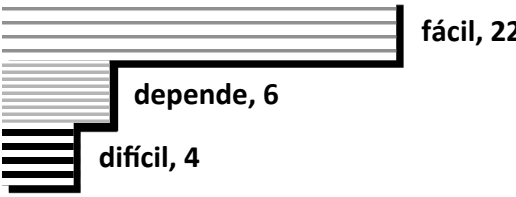

Gráfico 41: Questionários - Respostas às pergunta do item 16 
As perguntas abaixo foram incluídas no questionário a partir da constatação, durante a realização das entrevistas não-diretivas, de que um entrevistado, ao descrever sua prescrição, repetia “de 8 em 8 horas”, mas não entendia o que essas palavras significavam. Foram incluídas então quatro perguntas relativas aos intervalos entre as doses.

Para tabulação das reposta, foi considerado que o entrevistado compreendeu os intervalos "duas vezes ao dia" e "de 12 em 12 horas" quando este afirmou que tomaria o medicamento duas vezes durante o dia em turnos diferentes. Foi considerado que o paciente compreendeu os intervalos "três vezes ao dia" e "de 8 em 8 horas" quando o respondente afirmou que tomaria o medicamento três vezes ao longo do dia, em turnos diferentes.

As descrições dos intervalos "duas vezes ao dia" e "três vezes ao dia" são, segundo as repostas dadas, mais compreensíveis do que o intervalo expresso em horas. Entretanto, mesmo dessa maneira, os intervalos não foram compreendidos por três pacientes, no caso de duas vezes por dia, e 4 pacientes, para 3 vezes ao dia.

Para a pergunta na qual o intervalo descrito foi "de 12 em 12 horas", o número de incompreensão duplica, não sendo compreendida por 8 respondentes. E o intervalo "de 8 em 8 horas" não foi compreendido, considerando-se os critérios de compreensão adotados, por 27 dos 35 entrevistados.

Este resultado indica que uma diferença da forma de expressão que pode passar despercebida para o prescritor pode se decisiva para a compreensão do tratamento pelo paciente. 


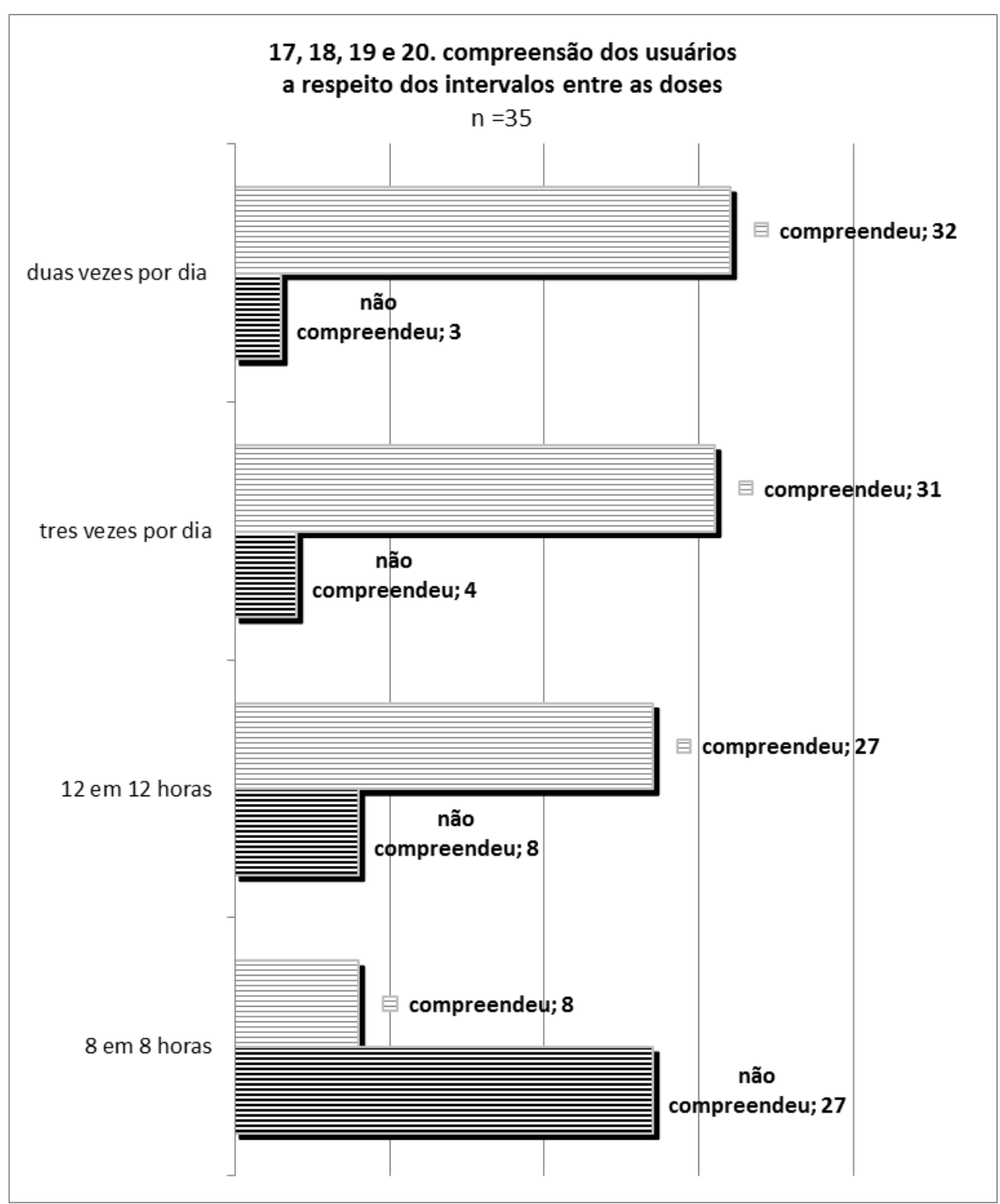

Gráfico 42: Questionários — Respostas às perguntas 17, 18, 19 e 20 


\subsection{Entrevistas focadas}

\subsubsection{Participantes das entrevistas focadas}

Das 10 mulheres entrevistadas, nove eram pacientes, e uma acompanhante de sua mãe, em tratamento de enfermidades crônicas ${ }^{29}$. A metade das pacientes tinha mais de 65 anos, e todas tinham renda até 3 salários mínimos. Quanto à escolaridade, duas não haviam frequentado escola e uma tinha curso superior. A doença mais referida foi hipertensão, por 8 das 10 respondentes. A grande maioria das pacientes já faz tratamento para enfermidades crônicas há mais de 5 anos e também a maioria toma mais de 3 medicamentos. A metade das pacientes usa medicamentos prescritos por dois médicos, e a outra metade é atendida por um médico.

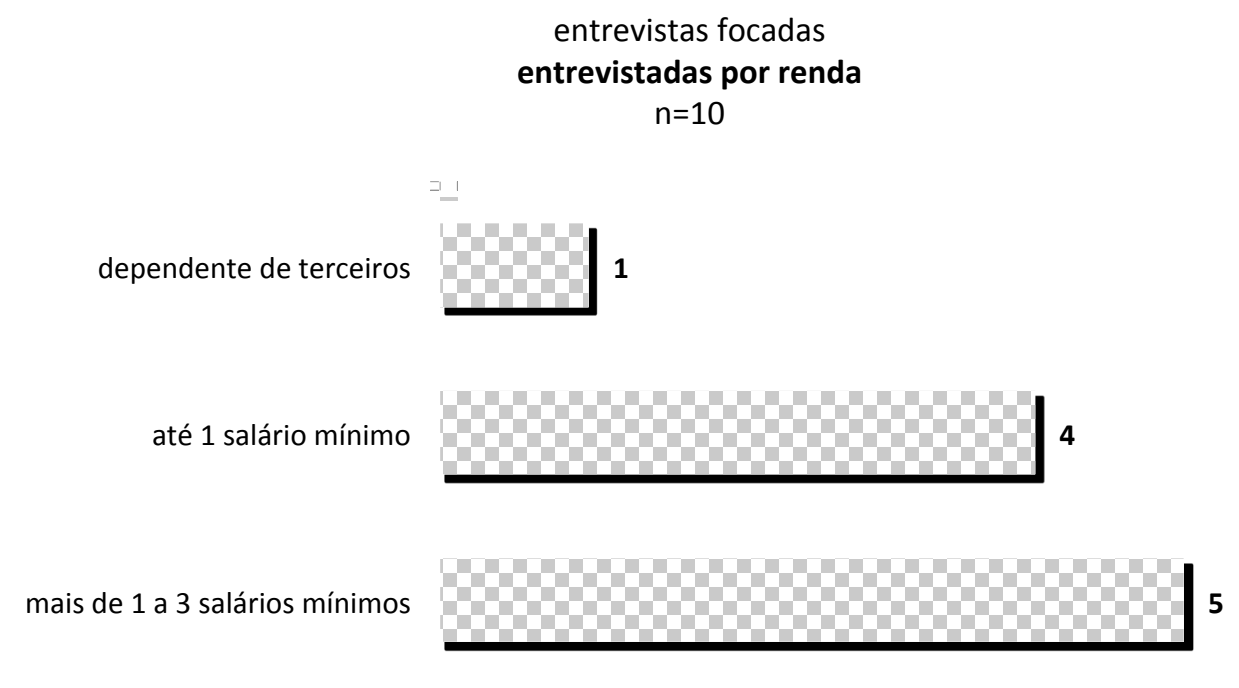

Gráfico 43: Entrevistas focadas — Entrevistadas por faixa de renda

29 Para elaboração dos gráficos relativos aos dados apresentados nesta sessão utilizou-se os dados de escolaridade e renda da filha/acompanhante. Pois, apesar de não ser paciente, é a entrevistada que acompanha a mãe nas consultas, providencia a obtenção dos medicamentos e os administra. Já os dados de saúde e tratamento de saúde tabulados são os da mãe/paciente. 


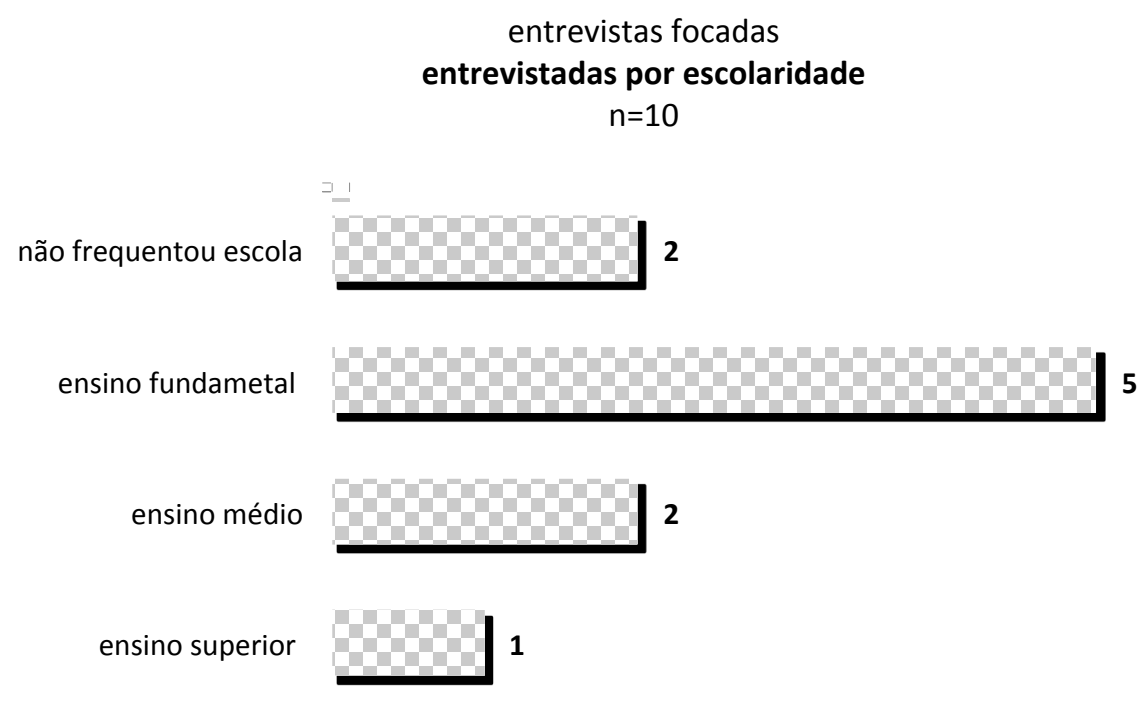

Gráfico 44: Entrevistas focadas - Entrevistadas por escolaridade

Os dados abaixo são relativos às pacientes participantes desta etapa da pesquisa - 9 entrevistadas diretamente e uma, presente na entrevista, mas representada por sua filha, que respondeu às perguntas, e participa de todas as consultas e exames e administra os medicamentos.

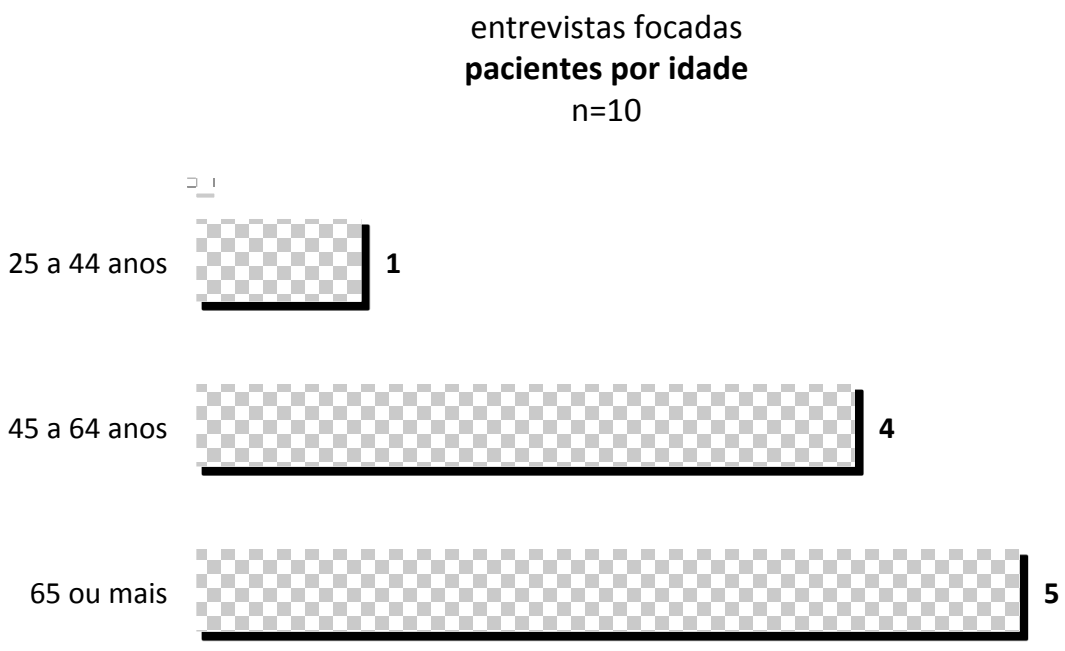

Gráfico 45: Entrevistas focadas - Entrevistados por idade 


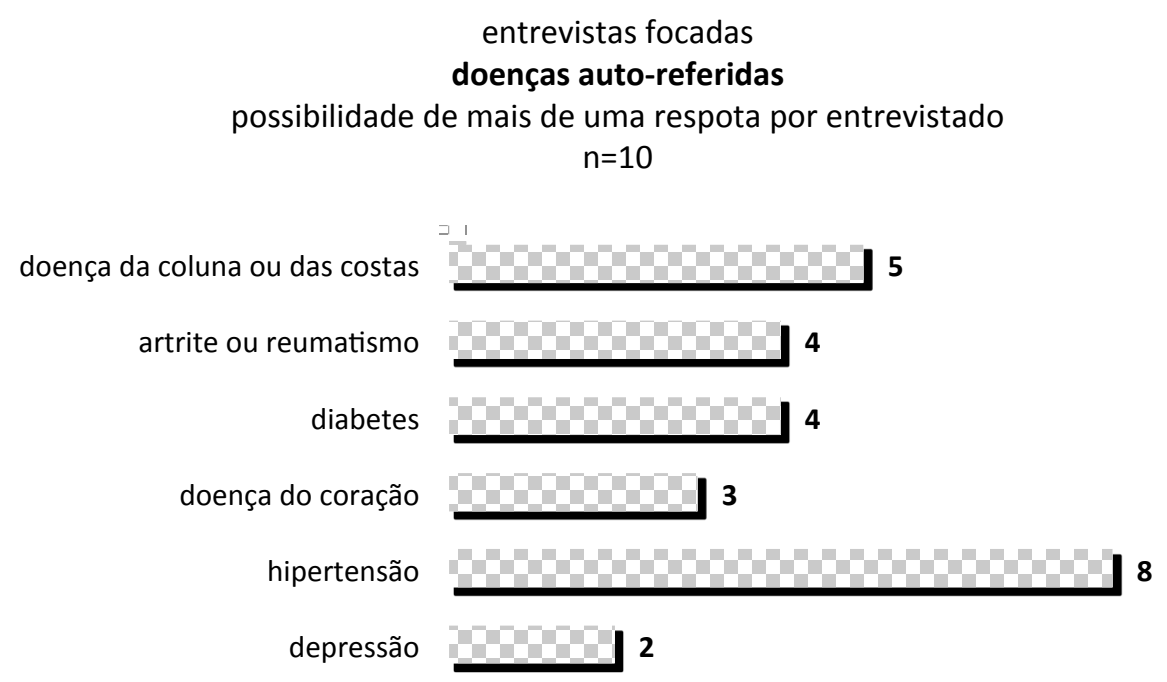

Gráfico 46: Entrevistas focadas - Doenças auto referidas

entrevistas focadas

pacientes por tempo de tratamento de doenças crônicas

$n=10$

5 anos ou

mais

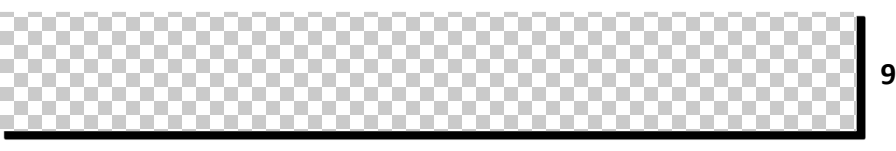

de 1 a 5 anos

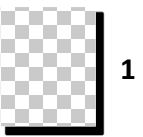

Gráfico 47: Entrevistas focadas - Tempo de tratamento dos paciente para enfermidades crônicas 
entrevistas focadas

pacientes por número de medicamentos diferentes que tomam diáriamente

$$
\mathrm{n}=10
$$

1 a 3

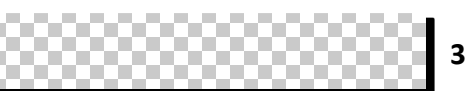

4 a 7

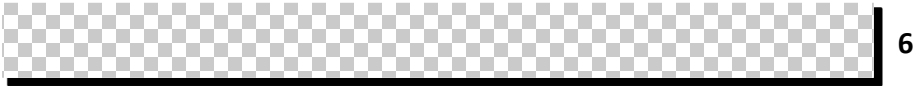

8 ou mais

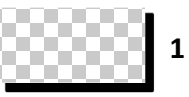

1

Gráfico 48: Entrevistas focadas - Número de medicamentos usados diariamente pelo paciente

entrevistas focadas

pacientes por número de médicos prescritores

$n=10$

1 médico

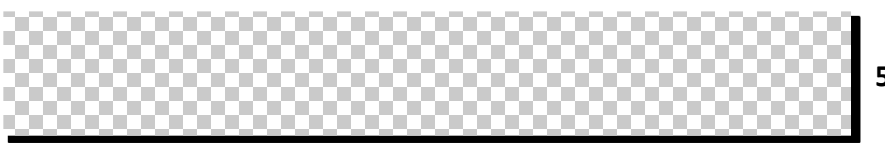

2 médicos

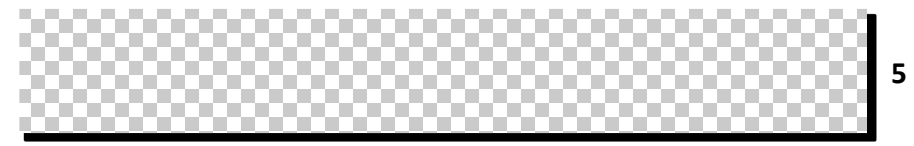

Gráfico 49: Entrevistas focadas - Por número de médicos prescritores do paciente 


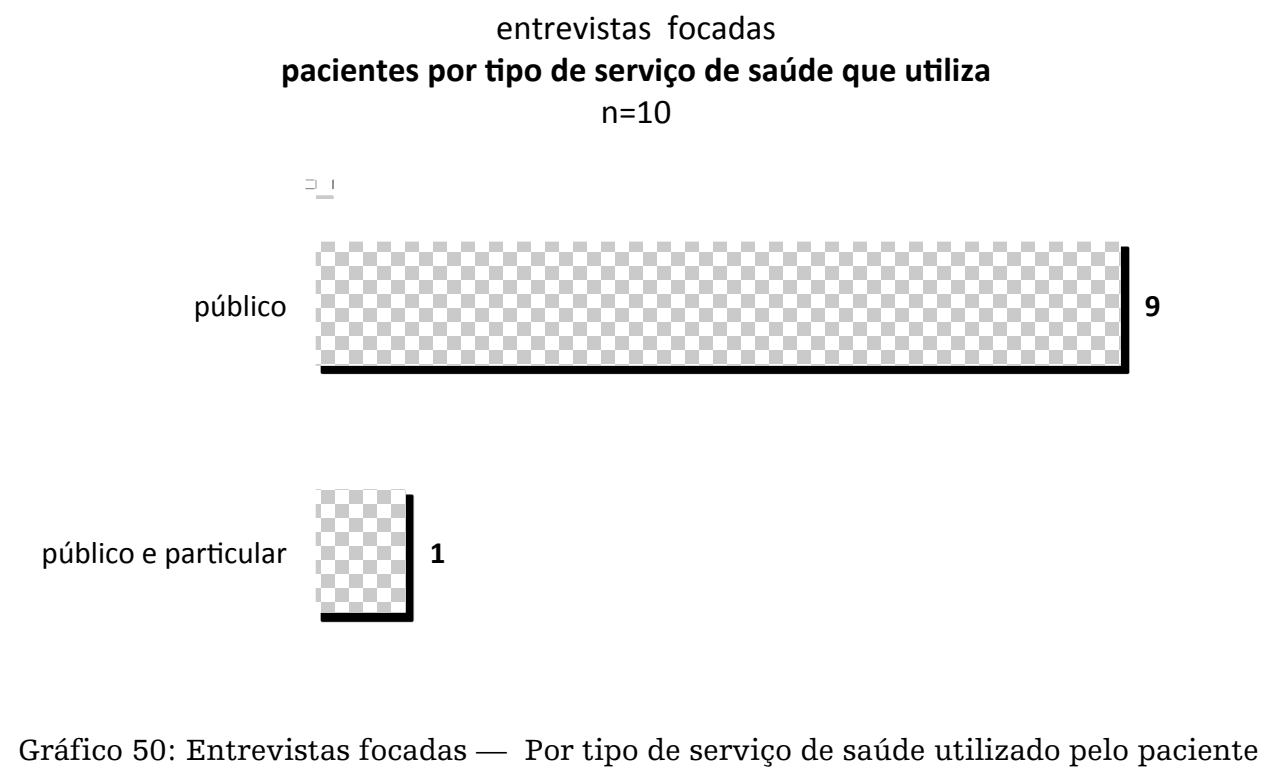

\subsubsection{Análise de conteúdo: categorização}

As categorias utilizadas na análise de conteúdo das entrevistas focadas seguiram a sistematização realizada na análise de conteúdo das entrevistas nãodiretivas, e posteriores ajustes, relatadas no tópico 7.1.2.3 Ajustes nas categorias.

A seguir são apresentadas as categorias a partir da análise de conteúdo das entrevistas focadas realizadas:

\subsection{Compreensão e feedback do tratamento medicamentoso prescrito /} problemas e dificuldades

Desta categoria fazem parte todas as codificações relativas à compreensão da prescrição. Ou seja: medicamentos prescritos, doses, horários e intervalos ou qualquer outra orientação a respeito dos medicamentos prescritos e sua administração, seja ela informada de forma impressa ou verbal.

Inclui codificações relativas às dúvidas do paciente relativas ao seu tratamento e seu esclarecimento, seja por meio verbal ou impresso.

\section{Obtenção dos medicamentos}

Desta categoria fazem parte todas as codificações relativas à obtenção dos medicamentos prescritos.

\section{Uso dos medicamentos}


Nesta categoria foram incluídas todas as codificações relacionadas à administração dos medicamentos pelo respondente, tomada dos medicamentos, incluindo horário e dose. Relaciona-se diretamente com a compreensão da prescrição, mas aborda a rotina do paciente fora do ambiente hospital / consultório, quando este deve administrar por sua conta a prescrição.

\section{Outras questões relacionadas}

Nesta categoria foram incluídos trechos que apresentavam relatos relevantes na utilização de medicamentos, mas que não estavam diretamente relacionados com problemas ou soluções das categorias 1, 2 ou 3 .

A tabela abaixo apresenta as categorias inicialmente trabalhadas na análise de conteúdo, e ao lado desta, as categorias conforme as modificações apresentadas acima. 


\begin{tabular}{|c|c|}
\hline $\begin{array}{l}\text { Divisão geral inicial } \\
\text { (definidas na análise de conteúdo } \\
\text { das entrevistas não-diretivas) }\end{array}$ & $\begin{array}{l}\text { Divisão geral } \\
\text { (definidas na análise de conteúdo } \\
\text { das entrevistas focadas) }\end{array}$ \\
\hline $\begin{array}{l}\text { Compreensão do tratamento } \\
\text { medicamentoso prescrito }\end{array}$ & \multirow{3}{*}{$\begin{array}{l}\text { Compreensão e feedback } \\
\text { do tratamento medicamentoso prescrito } \\
\text { Desta categoria fazem parte todas as codificações } \\
\text { relativas à compreensão do tratamento } \\
\text { medicamentoso prescrito; dúvidas do paciente } \\
\text { relativas ao seu tratamento; e seu esclarecimento } \\
\text { por meio verbal ou impresso ocorrido no } \\
\text { ambiente de prescrição e dispensação. } \\
\text { Estão incluídos nesta categoria problemas ou } \\
\text { estratégias do paciente relativos à obtenção de } \\
\text { informações de seu tratamento medicamentoso } \\
\text { prescrito; compreensão dos medicamentos } \\
\text { prescritos e suas indicações, doses, horários e } \\
\text { intervalos ou qualquer outra orientação a } \\
\text { respeito do uso de medicamentos que se referem } \\
\text { às etapas de prescrição e dispensação e que foram } \\
\text { codificados nesta categoria. }\end{array}$} \\
\hline $\begin{array}{l}\text { Desta categoria fazem parte todas as codificações } \\
\text { relativas à compreensão da prescrição. } \\
\text { Ou seja: medicamentos prescritos, doses, horários } \\
\text { e intervalos ou qualquer outra orientação a } \\
\text { respeito dos medicamentos prescritos e sua } \\
\text { administração, seja ela informada de forma } \\
\text { impressa ou verbal. }\end{array}$ & \\
\hline $\begin{array}{l}\text { Feedback do tratamento } \\
\text { Inclui codificações relativas às dúvidas do } \\
\text { paciente relativas ao seu tratamento e seu } \\
\text { esclarecimento, seja por meio verbal ou impresso. } \\
\text { Se relaciona diretamente com a categoria } \\
\text { Compreensão do tratamento medicamentoso } \\
\text { prescrito e se distingue desta pelo fato de não } \\
\text { apresentar questões relativas à informação } \\
\text { apresentada pelo profissional de saúde, e sim } \\
\text { informações apresentadas pelos usuários } \\
\text { relativas aos seus tratamentos medicamentosos. }\end{array}$ & \\
\hline Obtenção dos medicamentos & Obtenção dos medicamentos \\
\hline $\begin{array}{l}\text { Desta categoria fazem parte todas as codificações } \\
\text { relativas à obtenção dos medicamentos } \\
\text { prescritos. }\end{array}$ & $\begin{array}{l}\text { Desta categoria fazem parte todas as codificações } \\
\text { relativas à obtenção dos medicamentos } \\
\text { prescritos. }\end{array}$ \\
\hline \multirow{3}{*}{$\begin{array}{l}\text { Administração dos medicamentos } \\
\text { Nesta categoria foram incluídas todas as } \\
\text { codificações relacionadas à administração dos } \\
\text { medicamentos pelo respondente, tomada dos } \\
\text { medicamentos incluindo horário e dose. Se } \\
\text { relaciona diretamente com a compreensão da } \\
\text { prescrição, mas aborda a rotina do paciente fora } \\
\text { do ambiente hospital / consultório, quando este } \\
\text { deve administrar por sua conta a prescrição. }\end{array}$} & Uso dos medicamentos \\
\hline & $\begin{array}{l}\text { Nesta categoria foram incluídas todas as } \\
\text { codificações relacionadas ao uso dos } \\
\text { medicamentos incluindo identificação do } \\
\text { medicamento, horário, dose, organização do } \\
\text { paciente ou qualquer outro elemento relativo a } \\
\text { quando este usa os medicamentos prescritos. Se } \\
\text { relaciona diretamente com a categoria } \\
\text { 1. Compreensão e feedback do tratamento } \\
\text { medicamentoso prescrito, mas diz respeito à } \\
\text { rotina de uso de medicamentos pelo paciente fora } \\
\text { do ambiente hospital / consultório. }\end{array}$ \\
\hline & $\begin{array}{l}\text { Outras questões relacionadas } \\
\text { Nesta categoria foram incluídos trechos que } \\
\text { apresentavam relatos relacionados à utilização de } \\
\text { medicamentos mas que não estavam diretamente } \\
\text { relacionados com problemas ou soluções das } \\
\text { categorias } 1,2 \text { ou } 3 \text {. }\end{array}$ \\
\hline
\end{tabular}

Tabela 6: Pré-categorias e categorias definidas 
Foi mantida a subdivisão para composição das categorias de codificação definida durante a análise de conteúdo das entrevistas não-diretivas tendo sido dividida cada categoria principal, exceto para o novo grupo: Outras questões relacionadas as duas subcategorias definidas:

Problemas e dificuldades: Apresenta as dificuldades ou imprecisões expostas pelos usuários durante os seus relatos, segundo a categoria maior à qual ela está vinculada.

Métodos e soluções: Apresenta as técnicas e soluções utilizadas pelo usuário no seu tratamento medicamentoso, e narradas ou apresentadas pelos usuários durante as entrevistas.

A categoria 4 - Outros problemas relacionados - não foi dividida em subcategorias, pois os trechos codificados apresentavam observações dos pacientes que nem sempre se referiam a problemas ou soluções encontradas. Sua inclusão se deu para complementar a etapa qualitativa de análise dos dados com informações relevantes associadas à utilização de medicamentos apresentadas pelos entrevistados.

Abaixo, os grupos e categorias definidas na análise de conteúdo:

1- Compreensão do tratamento medicamentoso prescrito e feedback 1.1 Compreensão do tratamento medicamentoso prescrito e feedback / problemas e dificuldades.

1.2 Compreensão do tratamento medicamentoso prescrito e feedback / métodos ou soluções.

2- Obtenção dos medicamentos

2.1 Obtenção dos medicamentos / problemas ou dificuldades

2.2 Obtenção dos medicamentos / métodos ou soluções

3- Uso dos medicamentos

3.1 Uso dos medicamentos / problemas ou dificuldades

3.2 Uso dos medicamentos / métodos ou soluções

4. Outras questões relacionadas 


\subsubsection{Resultados e discussão}

Observa-se que as entrevistas não-diretivas foram respondidas por 20 participantes, e em sua análise de conteúdo foram codificados 236 trechos. Já nas entrevistas focadas foram entrevistados 10 pacientes/acompanhantes e foram codificados 146 trechos. Portanto a comparação apresentada acima se restringe à relação de problemas e dificuldades e métodos e soluções apresentados segundo os quatro grupos gerais.

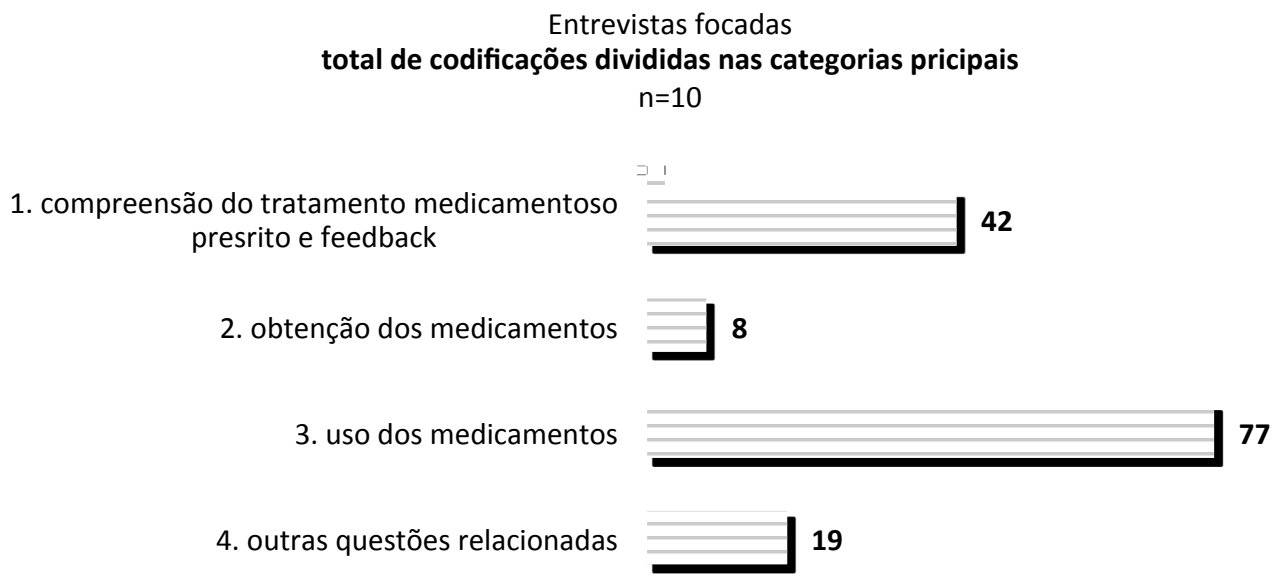

Gráfico 51: Entrevistas focadas — Total da codificação segundo a divisão geral

A partir do gráfico acima observamos que a maioria das codificações, 77, foram na relacionadas ao Uso de medicamentos, representado mais de $50 \%$ dos 146 trechos codificados.

A Compreensão do tratamento foi o segundo grupo com maior número de trechos, 42, com aproximadamente $28 \%$ das codificações. Outras questões relacionadas tiveram 19 trechos e Obtenção dos medicamentos, 8 . 
Entrevists focadas

total de trechos codificados com divisão de subcategorias $n=10$

1.1 Compreesão do tratamento medicamentoso prescrito e feedback / problemas e dificuldades

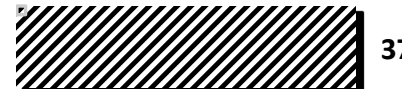

1.2 Compreesão do tratamento medicamentoso prescrito e feedback / métodos ou soluções

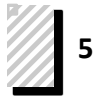

2.1 Obtenção dos medicamentos / problemas ou dificuldades

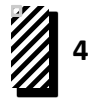

2.2 Obtenção dos medicamentos / métodos ou soluções

3.1 Uso dos medicamentos / problemas ou dificuldades

12

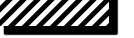

3.2 Uso dos medicamentos / métodos ou soluções

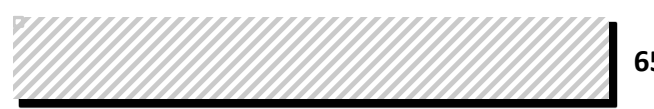

4. Outras questões relacionadas

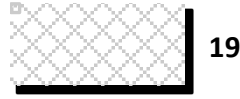

Gráfico 52: Entrevistas focadas

Total de trechos codificados com divididas em todas as categorias

Acima são apresentadas o total de trechos codificados nas suas respectivas categorias. Observa-se, corroborando os resultados apresentados na análise de conteúdo das entrevistas não-diretivas, que a categoria 1.1 Compreensão do tratamento medicamentoso prescrito e feedback / problemas e dificuldades apresentou um número expressivamente maior de codificações do que a categoria 1.2 Compreensão do tratamento medicamentoso prescrito e feedback / métodos e soluções. A mesma relação ocorreu na análise das entrevistas não-diretivas, nas duas categorias preliminares de análise do conteúdo, 1.2 Compreensão do tratamento medicamentoso prescrito / problemas e dificuldades e 4.1 Feedback do tratamento / problemas e dificuldades, que, somadas, tiveram 83 trechos codificados, contra apenas 4 trechos codificados apresentando métodos ou soluções. 
Resultado semelhante ao da análise das entrevistas não-diretivas também ocorreu nas categorias relativas ao Uso de medicamentos. Na análise de conteúdo das entrevistas não-diretivas a pré-categoria 3.2 Administração de medicamentos / métodos e soluções foram responsáveis pela maioria dos trechos codificados (66) e apenas 12 trechos foram codificados na categoria 3.1 Administração de medicamentos / problemas e dificuldades.

Diferente da codificação preliminar, onde não foram apresentados métodos e soluções do usuário na obtenção de medicamentos, nesta etapa da pesquisa tiveram houve o mesmo número de codificações nas categorias 2.1 Obtenção dos medicamentos / problemas ou dificuldades e 2.2 Obtenção dos medicamentos / métodos ou soluções, cada uma com 4 trechos codificados. Esta categoria manteve a relação observada nos resultados das entrevistas nãodiretivas, tendo o número mis baixo e codificações (8) de um total de 146. 
Categoria 1:

Compreensão do tratamento medicamentoso prescrito e feedback

Entrevists focadas

total de trechos codificados na categoria

1. compreensão do tratamento medicamentoso prescrito e feedback

$\mathrm{n}=10$

1.1 Compreesão do tratamento medicamentoso prescrito e feedback / problemas e dificuldades

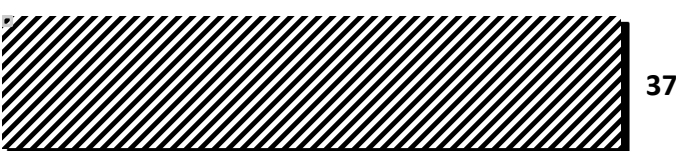

1.2 Compreesão do tratamento medicamentoso prescrito e feedback / métodos ou soluções

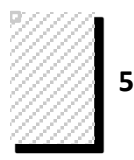

Gráfico 53: Entrevistas focadas

Total de trechos codificados nas categorias

1.1 Compreensão do tratamento medicamentoso prescrito e feedback /problemas e dificuldades, e 1.2 Compreensão do tratamento medicamentoso prescrito e feedback/métodos e soluções

1. l Problemas ou dificuldades

Dispensação sem informação

- Quando a senhora compra ou ganha, lá na [nome farmácia], o que é que eles te informam? ( $P$ )

- Fala nada não. Vai com a receita. Fala nada não. (E1)

- Quando recebe os remédios, te informam alguma coisa sobre os remédios, ou...não? Na hora que você recebe. (P)

- Quando tou comprando? (E5 - filha)

- Quando tá comprando. (P)

- Não, não. (E5 - filha)

- E quando a senhora recebe os remédios, na [farmácia popular], ele te fala alguma coisa sobre os remédios? ( $P$ )

- Não. (E2)

- E aqui, na farmácia aqui perto, eles te explicam alguma coisa? (P)

- Não (E2). 
Dos 46 trechos codificados que apresentam problemas ou dificuldades na compreensão do tratamento e feedback, 10 se referem a dispensação de medicamento sem informação; além dos relatos que se referiam diretamente à falta de informação na dispensação gratuita, subsidiada, ou venda comum de medicamentos, tanto nas unidades de saúde quanto na rede de farmácias populares ou drogarias da rede privada.

Observa-se que a falta de informação ao usuário na dispensação de medicamentos tem como consequência outros problemas apresentados relativos à compreensão do tratamento. Isto ocorre uma vez que a dispensação "é um ato farmacêutico no qual, além de proporcionar os medicamentos ao paciente, o farmacêutico informa e orienta o paciente sobre o uso adequado do medicamento. (OSÓRIO-DE-CASTRO E PEPE, 2011), que não está sendo cumprido.

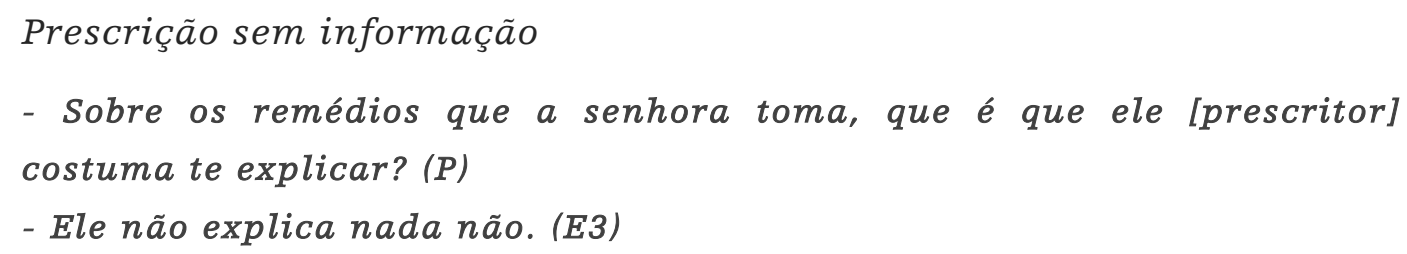

A falta de informação não ocorre somente na etapa de dispensação. Houve, ainda que em menor número, relatos de prescrição sem informação. Lembrando que, no ato de prescrição, o paciente deve ser informado e orientado a respeito da indicação, tempo de ação do medicamento, efeitos adversos, informação a respeito de sobredose, ingestão concomitante com outras substâncias e instrução para retorno (OMS, 1998), percebe-se a relevância da prescrição informada para possibilitar ao paciente o uso racional dos medicamentos.

Soma-se a esta a dispensação sem informação, apresentada anteriormente, e temos um paciente que, depois das duas primeiras etapas da utilização de medicamentos (prescrição e dispensação) passa para a etapa de do uso (OLIVEIRA; BERMUDES; OSÓRIO-DE CASTRO, 2007), sem que esteja informado e empoderado (WAGNER, 1998). 
- [...] Isso da pressão não baixar, né, a senhora tem alguma dúvida, disso? Assim. Alguma coisa que a senhora queria saber, sobre isso? (P)

- Não tem ninguém pra me explicar, né? (E4)

Problemas de comunicação na prescrição

- Você consegue entender o que o médico diz? (P)

- É. Mais ou menos (E3).

Foram codificados relatos que apresentam dificuldade na comunicação entre pacientes e prescritores. Os trechos das entrevistas evidenciam que pacientes têm dificuldade em compreender o que é dito pelos prescritores. Também foram relatados pelos entrevistados problemas em se expressar, serem ouvidos, compreendidos ou acreditados pelos profissionais de saúde que os atendem.

- Eu tenho dificuldade de me expressar, né? Então, eu até converso com ele [prescritor], mas... assim... Acho que, assim, com certa dificuldade. Converso e tudo, né, falo algumas coisas, Aí dentro dessas coisas ele chega a conclusão, né? (E9)

- Ele [prescritor] só ouve mais, e passa mais a receita (E9).

- Toda vez que eu vou, eles tiram a pressão, e vê! Aí pensa que não tomo. Tô tomando remédio direito. (E4)

A comunicação entre prescritor e paciente é fundamental para a prescrição adequada e que haja adesão ao tratamento. (OMS, 1988; BRADOCK et al, 2008). Os trechos acima corroboram pesquisas anteriores que apresentam a comunicação com o prescritor é o elemento mais decisivo para o uso racional dos medicamentos, que entretanto, vem ocorrendo de forma insatisfatória.

\section{Falta de elementos impressos}

Segundo os relatos dos entrevistados nesta pesquisa, a bula ao paciente não vem sendo dispensada juntamente com o medicamento nas unidades de saúde pública, quando estes são dispensados sem caixa. Houve também dois relatos da receita médica ter ficado retida na dispensação. 
A falta da informação impressa obrigatória impede o paciente de rever e consultar a prescrição e informações do medicamento prescrito.

- [...] os remédios que vieram [do hospital], não trazem receita. Não [pra esse remédio dispensado a farmácia do hospital] não tem bula, não. (E5 filha).

Os problemas observados nas etapas de prescrição e dispensação, assim como a falha na disponibilização de informação impressa obrigatória para os pacientes crônicos ou seus acompanhantes, têm seu reflexo em falhas no conhecimento do paciente / acompanhante quanto a informações a respeito do seu tratamento, como a ação do medicamento, dose, e efeitos adversos, conforme apresentado a seguir.

Desconhecimento ou dúvidas do paciente a respeito do medicamento : nome, ação e dose

Dos trechos codificados na categoria 1.1 Problemas ou dificuldades na compreensão do tratamento ou feedback, 9 apresentaram desconhecimento ou dúvidas do paciente relativos à ação do medicamento.

- Pra que é esse aqui, a senhora sabe?(P)

- Tudo pra pressão. (E4)

- [nome do medicamento](P).

- Deve ser pro coração. (E4)

A dose prescrita também é fator de dúvida para paciente. No trecho abaixo a paciente deve alternar duas doses diferentes de um mesmo medicamento, mas desconhece qual dose deve ser tomada durante três dias, e qual deve ser tomada durante quatro dias. 
- A senhora toma três dias um lo medicamento em uma determinada dose], três dias outro [de dose diferente [...] Qual [dose] que é três? [...] (P)

- Eu acho que pode ser qualquer um, porque vai sobrar. (E1).

Observa-se, entretanto, que os problemas na compreensão da ação do medicamento não ocorrem isolados de outros problemas na compreensão do tratamento. No trecho codificado abaixo a paciente considera que todos os medicamentos têm como ação a diminuição do sintoma de dor nas pernas, e continua explicando que toma tudo junto.

- Esse é pra dor nas pernas, a senhora falou (P).

- Tudo. Tudo uma coisa só (E2); tomo tudo junto. (E2)

Foi identificado que desconhecimento do paciente a respeito dos medicamentos ocorrem já na identificação do nome destes. Vale ressaltar que para o desconhecimento do paciente a respeito do seu tratamento indica falhas tanto na prescrição, como na dispensação de medicamentos, uma vez que são etapas que incluem a informação ao paciente. A escolaridade é um fator decisivo nesse aspecto. Este fator é de grande relevância ao se analisar a utilização do medicamentos para enfermidades crônicas, pois diversos estudos apontam ser a população com baixa escolaridade a que mais tem dificuldade em administrar de forma consciente seus medicamentos. (OMS, 2007, ALMEIDA et al., 2002; ACKI et al, 2002; CASANOVA; STARFIELD,1995)

Isto se agrava no caso de pacientes sem alfabetização, que não podem consultar nenhum dos elementos impressos que fazem parte do uso dos medicamentos: receita, bula, caixa, cartela, para obter esta informação, ficando restrito à informação verbal transmitida. 
- A senhora toma esse aqui. A senhora sabe o nome dele? (P)

- Ah! Eu não lembro não. Eu não sei ler. Você não sabe não (E2)?

A compreensão da prescrição médica (documento legal) e identificação dos medicamentos presentes nesta também pode apresentar problema. No trecho abaixo, a paciente apresentou à entrevistadora medicamentos em uso diferentes dos dois medicamentos prescritos. Apesar de ser elemento, e regulado por diversas normas (OSÓRIO DE CASTRO; PEPPE, 2011) conforme apresentado na tabela 2 da presente pesquisa, observou-se que a prescrição médica (documento legal) não está de acordo com as normas que a regulam. Na seção 2.1 será apresentada a rotina de uso de medicamentos por esta paciente, que reflete a dificuldade de compreensão do seu tratamento.

- Isso tudo que tá aqui em cima, que o médico mandou tomar. Mas ele só escreveu essas duas, foi isso? ( $P$ )

- Esses aí, acho que não tinha no posto. Ou tinha, não sei...não tô bem lembrada, não. (E7)

Prescrição em desacordo com o paciente

Observa-se no trecho abaixo um desacordo entre a paciente e os profissionais que a atendem, onde ela relata desconfiança dos profissionais a respeito de sua adesão ao tratamento e, logo em seguida, desconfiança da paciente com relação à prescrição.

- Eles [profissionais do serviço de saúde] pensam que a senhora não toma [o medicamento]?(P)

- Pensam que não toma. Não sei! Tomo o remédio. Falei pra ele: "Tem que mudar?" -"Não, o remédio da pressão é esse mesmo". Então, pronto. (E4)

\section{2 Métodos ou soluções}

Foram codificados 4 trechos de métodos e soluções apresentados pelos pacientes para compreensão feedback do tratamento medicamentoso prescrito. 


\section{Acompanhante}

A presença de um acompanhante na consulta foi citada como um fator de colaboração para a compreensão do tratamento. Vale chamar atenção que uma entrevista foi realizada inteiramente com a acompanhante da paciente, o que denota uma estratégia de compreensão.

- [quem vai] Na consulta [comigo] é minha filha (E2).

Insistência

A insistência foi apresentada como elemento que colabora para resolução a compreensão do tratamento.

- o que é que o médico explica, pra você, você consegue tirar suas dúvidas, como é que é? (P)

- Consigo. Até porque sou bem insistente. (E5 - filha) 
Categoria 2:

Obtenção dos medicamentos

Entrevists focadas

total de trechos codificados na categoria

2. obtenção dos medicamentos

$n=10$

2.1 Obtenção dos medicamentos / problemas ou dificuldades

2.2 Obtenção dos medicamentos / métodos ou soluções

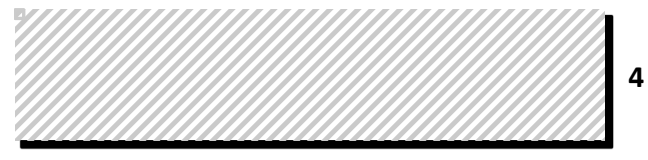

Gráfico 54: Entrevistas focadas

Total de trechos codificados na categoria

2. Obtenção de medicamentos

\subsection{Problemas ou dificuldades}

\section{Custo do medicamento}

Apesar da distribuição dos gestores estaduais e municipais na rede básica de saúde e de medicamentos anti-hipertensivos, antidiabéticos e antiasmáticos estarem disponíveis gratuitamente ou a preços reduzidos na rede de farmácia do Programa Farmácia Popular (Brasil, 2011), ainda ocorre dificuldade na obtenção de alguns medicamentos prescritos devido ao custo.

Três dos quatro problemas e dificuldades apontados para a obtenção dos medicamentos nas entrevistas realizadas são relativos ao custo do medicamento prescrito.

- Ainda não comprei foi o das varizes, porque não tem dinheiro... Ainda não comprei nem a meia, nem o das varizes. Vou comprar (E6). 
O outro problema descrito foi de um erro durante a dispensação, quando a prescrição foi retida por engano. Sem a prescrição, a paciente ficou impossibilitada de receber os medicamentos. Essa observação corrobora pesquisas anteriores que indicam problemas na dispensação que vão desde problemas na rotulagem de medicamento a falta de instrução sobrecarga de trabalho nos profissionais (ANACLETO et al, 2008).

- [...] agora, se eu tivesse a original [que ficou, por erro, em vez da cópia, no local de dispensação], eu ia lá. (E4)

\subsection{Métodos ou soluções}

Das quatro codificações de métodos dos usuários para obtenção de medicamentos, 3 foram a obtenção de medicamentos com conhecido que tinha o medicamento sobrando, e uma foi a obtenção do medicamento com o médico ${ }^{30}$.

- E ganhei também uma caixa do médico. Aí, ele tinha lá, que ele tinha ganhado, aí [o médico] me arrumou uma caixa (E9).

- Aí tem um vizinho aqui que também toma o [nome medicamento], aí ele me arrumou uma cartela. (E9).

Apesar de ter sido considerada, na presente análise de conteúdo, como uma solução - uma vez que o paciente solucionou a falta de acesso ao medicamento prescrito —, a dispensação do medicamento deve, legalmente, der feita por um farmacêutico.

30 Vale lembrar que, apesar de ser prática comum a dispensação realizada pelo médico, esta etapa da utilização de medicamento deve ser realizada pelo farmacêutico. (Brasil, 2008) 
Categoria 3:

Uso dos medicamentos

Entrevists focadas

total de trechos codificados na categoria

3. uso dos medicamentos

$n=10$

3.1 Uso dos medicamentos / problemas ou dificuldades

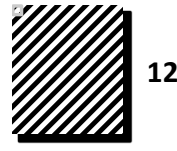

12

3.2 Uso dos medicamentos / métodos ou soluções

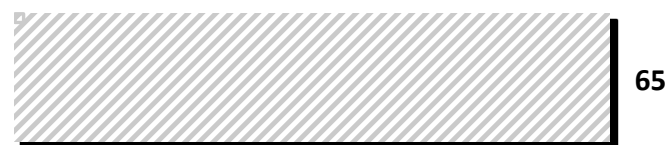

Gráfico 55: Entrevistas focadas

Total de trechos codificados na categoria

3. Uso dos medicamentos

$\mathrm{Na}$ categoria 3.1 e 3.2 , relativas ao Uso dos medicamentos, ocorre um número expressivamente menor de dúvidas e dificuldades (12) do que de métodos e soluções (66). Isto representa o oposto do ocorrido nas categoria 1.1 e 1.2, relativas à Compreensão do tratamento medicamentoso prescrito e feedback, onde as dificuldades foram a maioria dos trechos codificados.

Os métodos e soluções na utilização de medicamentos foi a categoria com maior número de trechos codificados (65) representando mais de $50 \%$ do total de codificações. 


\subsection{Problemas e dificuldades}

Simplificação dos intervalos entre tomadas de medicamentos

A simplificação dos intervalos de maneira voluntária pelo paciente consiste na administração dos medicamentos que deveriam ser tomados ao longo do dia em um horário só. Isto causa uma maior distância entre as doses, assim como doses excessivas. ${ }^{31}$

- Eu tomo todos os remédios, tudo numa hora só.

- Tudo de noite. (E2).

\section{Paciente não conseguiu localizar a receita}

O fato do paciente não ter conseguido localizar a receita médica atual foi considerado um problema no uso do medicamentos. Isto se deu pelo fato da receita ser o elemento impresso fundamental da prescrição do tratamento com medicamentos. Observou-se que os pacientes tinham a preocupação e o cuidado de guardar as receitas médicas anteriores, e que o fato de se acumularem várias receitas, todos papéis muito parecidos, dificultava a procura da receita atual.

- Essa é a última receita. Essa aqui que a sra. tá seguindo. (P)

- [...] Tenho tudo aqui, mas não tô achando? Vou fazer o quê? 2011. Eu fui lá em 2011. (E8)

\section{Efeito adverso}

Em dois trechos codificados as entrevistadas relataram não fazer uso do medicamento prescrito.

\footnotetext{
$31 \mathrm{Na}$ primeira análise de conteúdo realizada - entrevistas dão diretivas - trechos que apontavam que os horários de tomada de medicamentos simplificados ou seja, relativos à administração dos medicamentos que deveriam ser tomados ao longo do dia em um horário só, "tudo junto", foram considerados como métodos do paciente no uso de medicamentos. Apesar de ser uma forma encontrada pelo paciente para simplificar a administração dos medicamentos, optou-se, na segunda análise de conteúdo, por classificar-se trechos descrevendo esta simplificação como problemas ou dificuldades, pois entendeu-se que esta solução explicita a dificuldade do paciente em administrar os medicamento, além de expô-lo ao risco de superdoses e subdotes.
} 
- Não tomo todo dia, não. (E4)

- É. Por que a senhora não toma? (P)

- Porque urina muito, (E)

Paciente não considera diferenças entre medicamentos

Duas codificações apresentaram situação onde a paciente não considera as diferenças entre os medicamentos, e portanto, não distingue o medicamento que está tomando.

- Por que a sra. toma esses três? Toma esses três, e não esses outros, aqui? (P)

- Ainda não acabou! (E7)

- Como assim? (P)

- Não acabou esses daqui ó. Essa caixa tá lacrada. (E7)

- Tá. Então quando acaba [medicamento A] a sra. passa pra essa aqui. [medicamento $B]$ ?

- É. (E7)

Outros trechos codificados na categoria foram relativos ao esquecimento da hora de tomar os medicamentos e de comprimidas sem marcação de divisão para a dose prescrita. Este último problema está associado à dificuldade de obtenção do medicamento. $\mathrm{O}$ medicamento sem a marca para divisão adequada foi o obtido pela entrevistada com o vizinho, descrito no tópico 2.1 Obtenção de medicamentos - problemas e dificuldades.

- Quando [a dose prescrita] era de 2, e a sua receita era de 3, como você fazia? (P)

- Era de 3, mas era pra mim poder partir. Era só a metade.(E9)

- Aí você fazia como? - - em duas....? (P)

- E tirava a pontinha dele.(E9)

- Tirava a pontinha? Só a pontinha? e tomava o resto? Dividia ao meio?(P)

- Não. (E9)

- Não. (P)

- Dividia a pontinha. (E9)

3.2 Métodos e soluções

Os métodos e soluções presentes nas entrevistas e a utilização de medicamento encontrados dizem respeito aos seguintes tópicos. 
Organizar a prescrição por turnos ou refeições.

Diferente da organização da prescrição apresentada na bula (a partir de cada medicamento), 20 trechos codificados apresentavam a organização da prescrição por turnos, refeições ou ao acordar/ao dormir.

\section{Ajuda de outra pessoa: filha e vizinha}

Observou-se entre pacientes idosos a participação de uma ou mais pessoas que auxiliam na administração dos medicamentos. Os tipos de ajuda observados foram: administração dos medicamentos propriamente dita (separa e dá o medicamento para o paciente), deixar os medicamentos separados conforme os horários de tomada, preparação de tabelas ou outros elementos auxiliares no uso dos medicamentos.

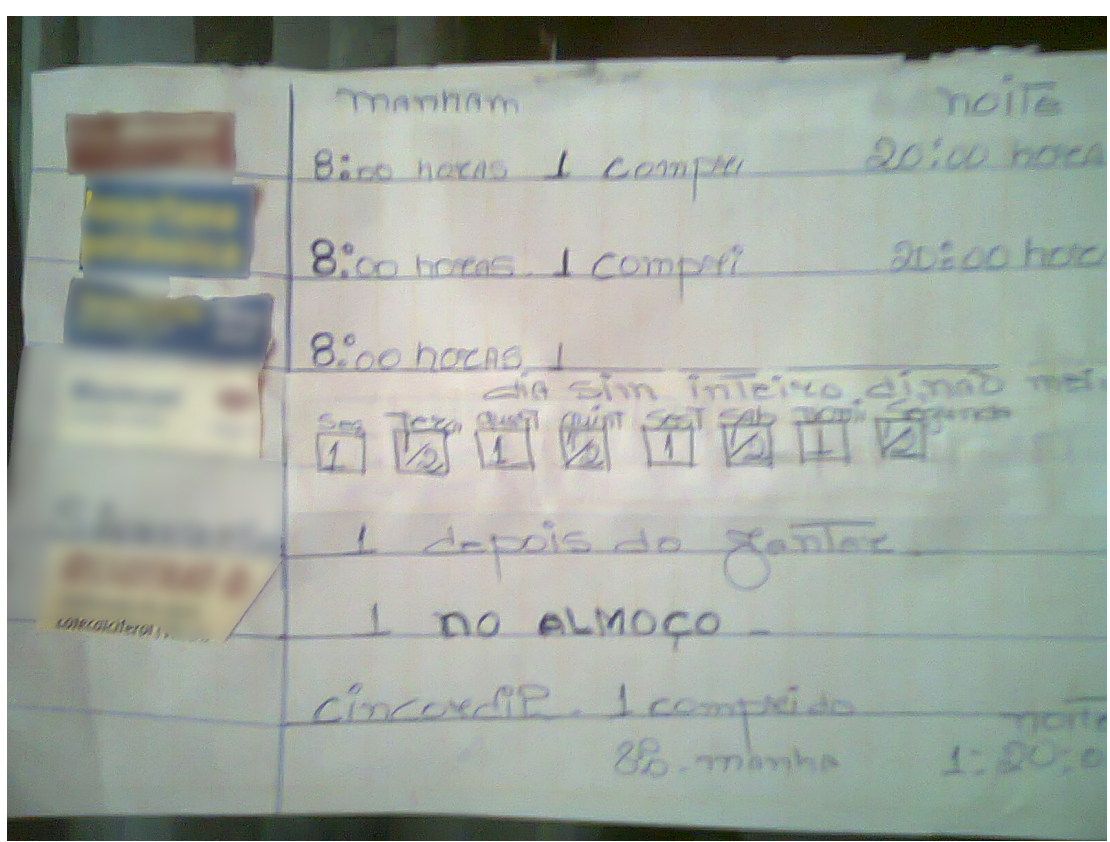

Foto 4: tabela uso de medicamentos preparada pela filha da paciente

Ocorre que esta ajuda pode ser feita por mais de uma pessoa, o que aumenta $\mathrm{o}$ risco de erros na administração dos medicamentes. $\mathrm{O}$ empoderamento do paciente, fator fundamental para o sucesso do tratamento (WAGNER, 2004) neste caso, não ocorre, uma vez que a administração dos medicamentos não passa pelo seu controle. No caso da paciente em questão, ela morava sozinha e administrava sua residência, mas não sentia-se apta a administrar seus medicamentos. 
Outras estratégias observadas foram identificação do medicamento por elementos gráficos: cor, tamanho forma, caixa, cartela ou comprimido., utilização de um recipiente para caixas e cartelas, utilização de um recipiente para comprimidos (potinhos), separar os comprimidos antes de tomar. e colocar o medicamento no cômodo da casa onde se encontra a hora de tomar o medicamento. ( $p$ ex. mesinha de cabeceira do quarto para medicamento que deve ser tomado em jejum)

\section{Categoria 4:}

Outras questões relacionadas

Entrevists focadas

total de trechos codificados na categoria

4. outras questões relacionadas

$\mathrm{n}=10$

Gráfico 56: Entrevistas focadas

Total de trechos codificados na categoria

4. Outras questões relacionadas

Uma questão apresentadas pelos pacientes que chamam a atenção é a dificuldade física de casso às instalações de atendimento a saúde (obstáculos arquitetônicos, que o impedem de acessar o próprio serviço d saúde.

Outro relato relevante foi a necessidade relatada pela paciente de provar para os profissionais de saúde que está administrando corretamente os medicamentos prescritos corretamente. Para isso, ela guarda as cartelas vazias, "provando" assim que aderiu ao tratamento. Ocorre que essa entrevistada não considera diferença entre os princípios ativos dos medicamentos administrados. 
- Todos eles num saquinho, até o que eu já tomei, eu guardo também. (E7)

- A cartelinha pura... (P)

- A cartelinha pura, eu guardo também. (E7)

- Entendi. Por que a sra. guarda, assim? (P)

- Eu guardo porque, qualquer coisa, pra eles [do serviço de saúde] verem que eu estou tomando, o remédio, né? (E7) 


\section{Conclusão}

\subsection{Prescrição}

A partir dos relatos apresentados pelos pacientes confirmou-se a ocorrência de dificuldade na comunicação apresentada na hipótese, assim como ausência de comunicação durante a consulta médica em que a prescrição é realizada.

A prescrição é a primeira etapa da utilização de medicamentos. Esta é a etapa em que ocorre, a partir da interação entre paciente e prescritor, a definição do tratamento a ser seguido. As falhas ocorridas nesta etapa vão afetar o ciclo de utilização.

\subsection{Dispensação}

Apesar da entrega dos medicamentos receitados para doenças crônicas quase sempre ocorrer de maneira eficiente, foi observado, durante a pesquisa, a precariedade da comunicação na etapa da dispensação. Isto porque, ao longo de todos os métodos aplicados, não houve nenhum relato de dispensação com informação ao paciente. Este problema foi relatado igualmente no fornecimento gratuito, subsidiado e de venda a preço regular de medicamentos.

Vale observar que a falta de acesso a alguns dos medicamentos prescritos gratuitamente ou a preços acessíveis faz com que o paciente procure obtê-los por outros meios. Por exemplo, a paciente que pediu a alguém que recebeu o medicamento , mas não fez uso deste. Ocorre que a dose não era adequada, causando ao paciente maior dificuldade para realizar seu tratamento. 


\subsection{Uso}

Os problemas de comunicação ocorridos na prescrição e dispensação estão presentes na administração sob a forma de confusão, dúvida, ou desconhecimento do paciente a respeito do seu tratamento. Isso se agrava pelo fato de muitos pacientes não saberem ou terem dificuldade em ler, reforçando assim a relevância da comunicação oral. Outro fator de dificuldade para o paciente é o fato dos medicamentos dispensados nas unidades de saúde não serem fornecidos com suas respectivas bulas, impedindo a tomada de informação escrita mesmo por pacientes alfabetizados.

Foi observado, a partir do referencial teórico apresentado no capítulo 2, que o foco da comunicação deve ser objeto de atenção. Este foco deve estar no apoio ao paciente na autoadministração do seu tratamento. Entretanto, observou-se que ele pode ser desviado do apoio para uma cobrança do paciente em relação ao cumprimento do tratamento. Isto foi observado a partir do relato da uma entrevistada que guarda todas as cartelas vazias utilizadas para "provar que tomou tudo direitinho". Entretanto, essa mesma paciente, ao tomar os medicamentos, relata não distinguir entre os diferentes os princípios ativos, tomando, quando um medicamento acaba, outro de princípio ativo diferente, para dar continuidade ao tratamento.

\subsubsection{Recursos de identificação dos medicamentos e apoio à administração:}

Um ponto relevante observado, no que diz respeito ao campo de experiência do paciente do tratamento na administração dos medicamentos, foi a utilização de recursos não escritos para a identificação e apoio à administração de medicamentos.

Esses recursos podem ser as características dos próprios medicamentos e suas embalagens ou outros elementos, conforme apresentado a seguir.

Relativos a medicamentos dispensados:

- forma, cor, tamanho, ranhuras e inscrições nos comprimidos,

- gosto e cheiro dos medicamentos,

- forma, tamanho e cor da cartela, 
- número de medicamentos nas cartelas,

- cor da caixa.

Outros elementos, utilizados como facilitadores na administração são providenciados ou elaborados pelos usuários. São eles:

- potinhos, bolsinhas, caixinhas para a armazenagem ou transporte dos medicamentos,

- tabela para organizar a administração dos medicamentos.

Nos pacientes sem escolaridade, outras formas de identificação dos medicamentos foram:

- a forma de uma letra característica do nome do medicamento e

- a forma do nome do medicamento.

Há ainda a utilização da própria residência como facilitador na administração. Uma providencia apresentada foi deixar os medicamentos que vão ser tomados em determinado momento da rotina em um local da casa associado a esta atividade. Um exemplo deste tipo de organização poderia ser: o medicamento que vai ser tomado no café da manhã no armário da cozinha, como fez uma das entrevistadas

Ainda a respeito dos elementos que facilitam e organizam a administração, chamou atenção a presença, na casa de vários entrevistados, de uma caixa onde eram recebidos os medicamentos em um extinto programa de dispensação. As caixas são ainda usadas para guardar medicamentos e ficam em local visível de muitas das residências visitadas. Isso pode apontar um caminho de comunicação entre serviço de saúde e pacientes, através de objeto que facilite a autoadministração de medicamentos. Vale ressaltar que uma ação nesse sentido requer pesquisa específica a respeito. 


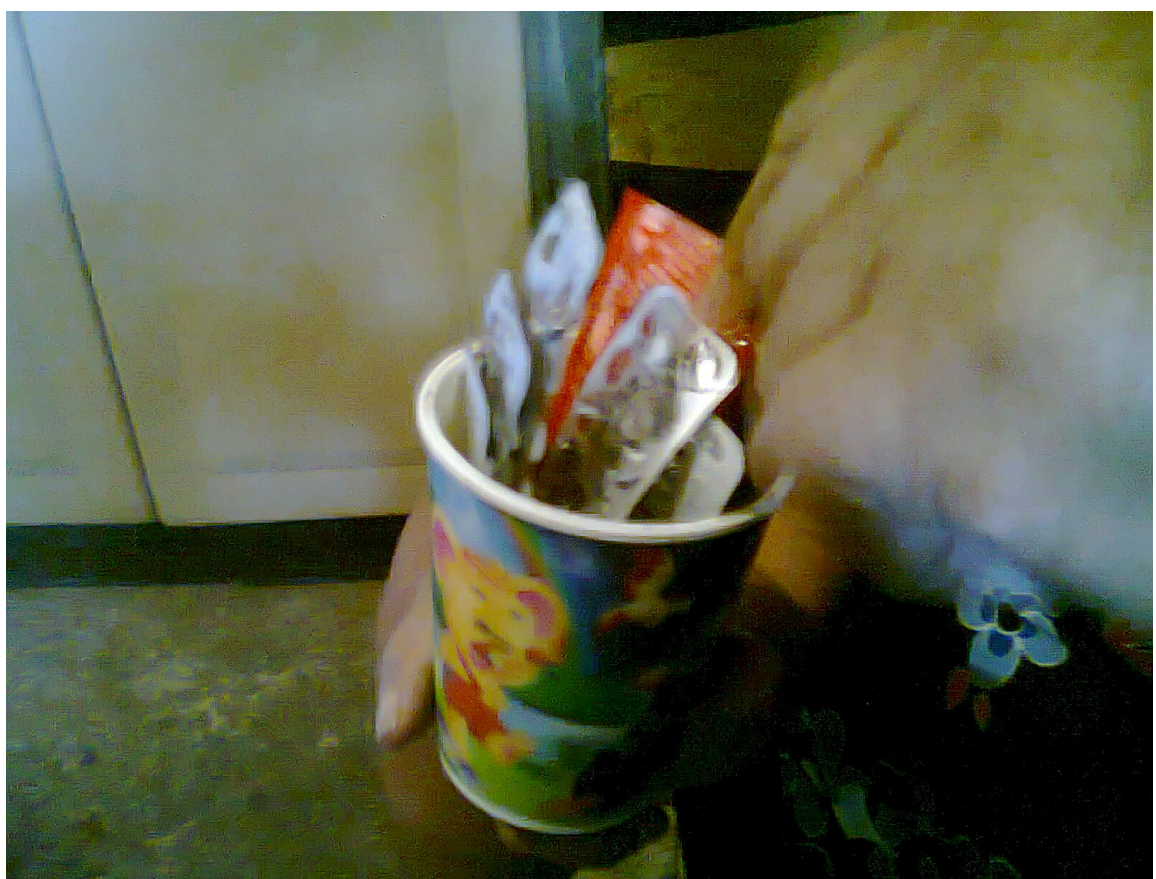

Foto 5: Potinho com medicamentos em uso

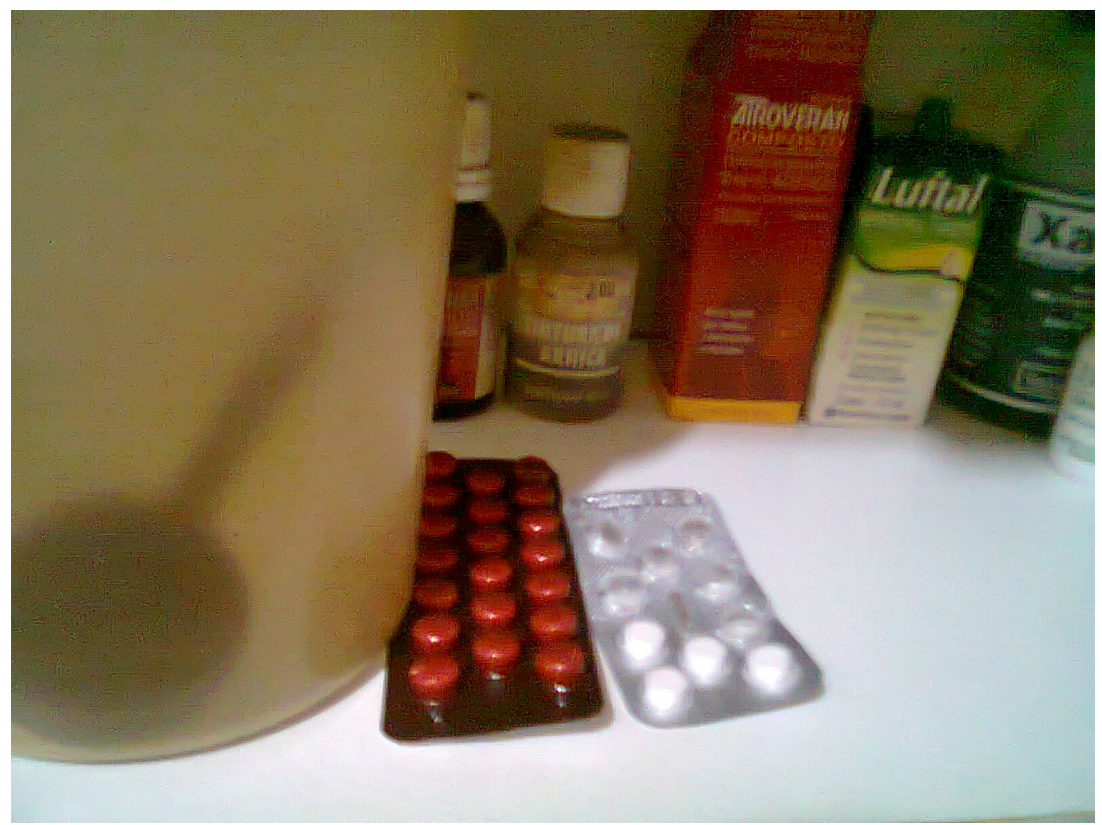

Foto 6: Medicamentos no armário da cozinha, para serem tomados no café da manhã 


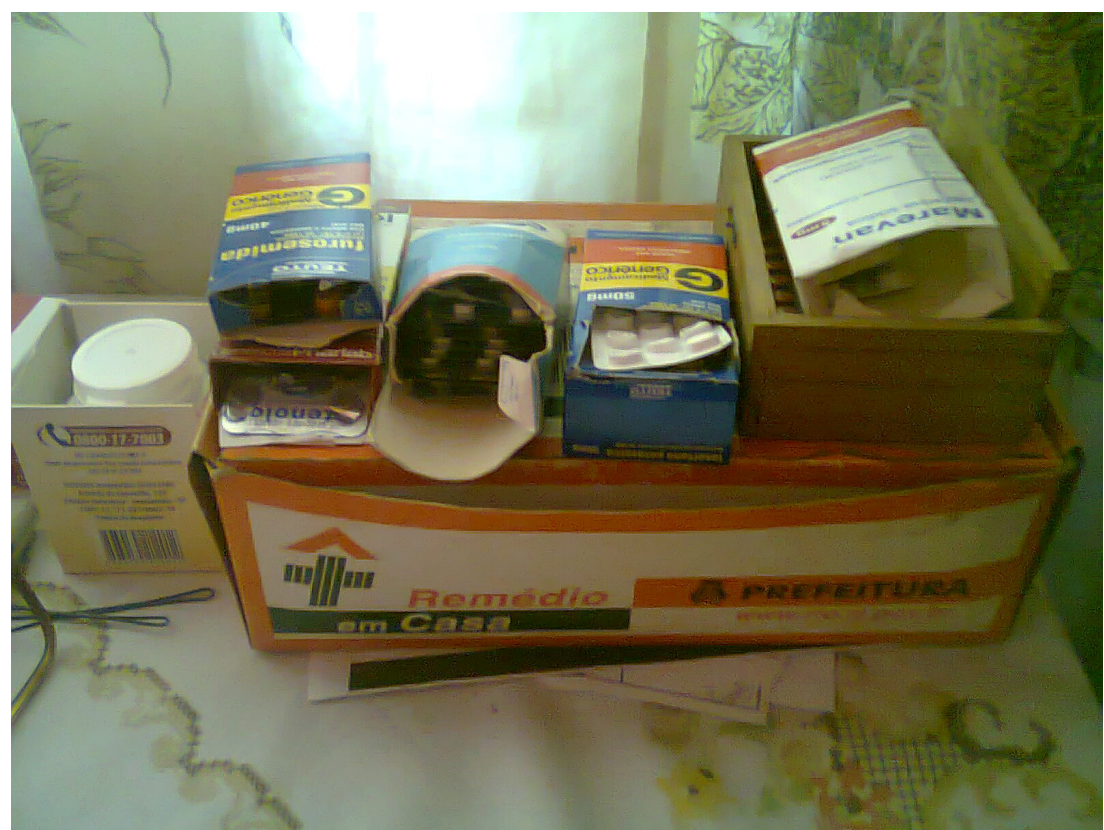

Foto 7: Caixa de extinto programa de dispensação de medicamentos ainda é utilizada pata armazenagem de medicamentos

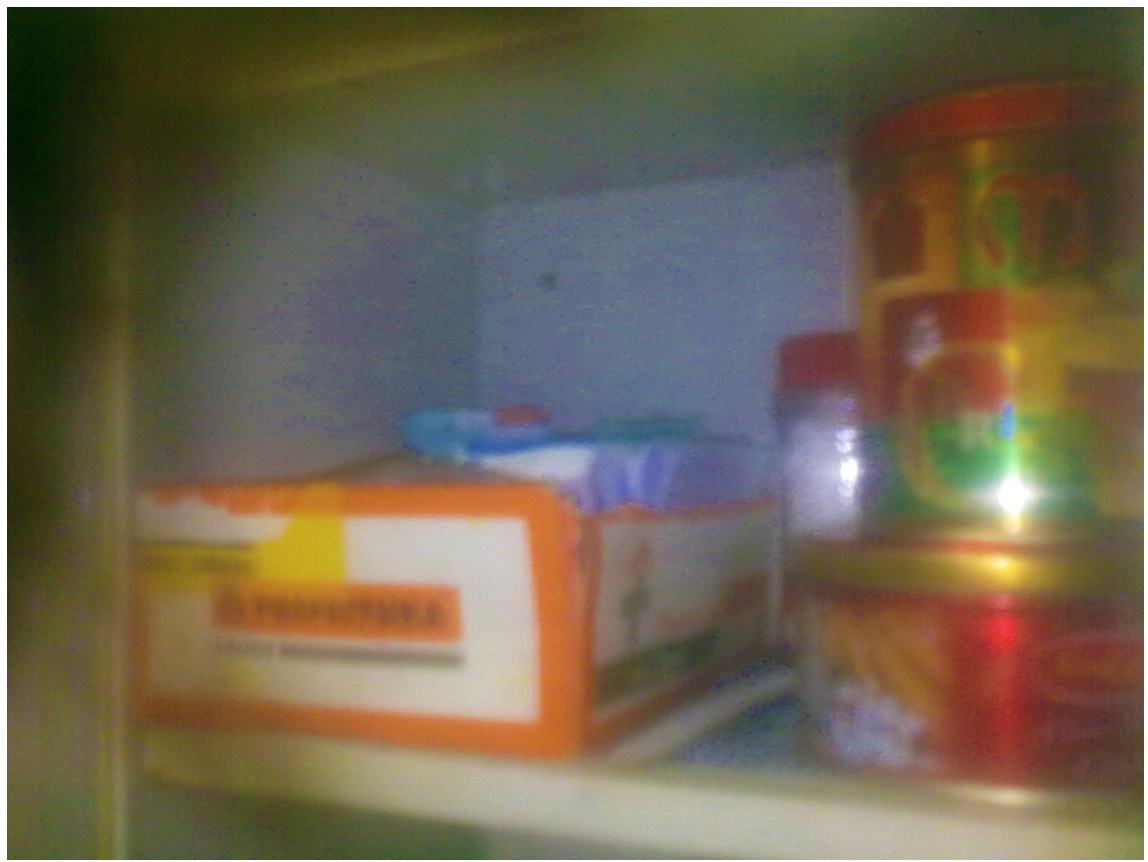

Foto 8: Caixa de extinto programa de dispensação de medicamentos ainda é utilizada pata armazenagem de medicamentos 


\subsection{Baixa escolaridade}

A falta de escolaridade ou baixa escolaridade entre os pacientes é uma prevalente nos pacientes portadores de doenças crônicas. As duas faixas com maior prevalência de doenças crônicas - idosos e pessoas com renda mais baixa são justamente as faixas sociais menos escolarizadas (IBGE 2010 e 2009).

Portanto, ao se considerar iniciativas para a melhoria no tratamento ambulatorial de doenças crônicas no Brasil, deve-se considerar primordialmente que as iniciativas sejam direcionadas a pessoas com baixa ou nenhuma escolaridade. Do ponto de vista de pessoas mais escolarizadas é difícil imaginar como uma pessoa sem alfabetização administra um tratamento medicamentoso complexo. No entanto, para esses pacientes, isto é mais uma tarefa cotidiana a ser realizada. Ocorre que, mesmo em pacientes com mais escolaridade, a identificação dos medicamentos não se dá somente pela leitura do seu nome, mas por vários elementos presentes nos medicamentos e suas embalagens.

Se a baixa escolaridade dificulta a comunicação, é importante observar que o problema de comunicação na utilização de medicamentos não se restringe a este grupo. Para exemplificar, podemos usar como exemplo o caso mais grave descrito pelas pacientes durante as entrevistas focadas: a surdez da mãe da entrevistada, consequência de efeito adverso não informado. A entrevistada tem curso superior, foi professora e diretora de escola. Entretanto, sua mãe foi ficando surda sem ela saber o motivo, até que ouviu comentários de outros pacientes que se submetiam a esse mesmo tratamento, de que poderia ser um efeito adverso do medicamento. 


\subsection{Medicamentos acessíveis e empoderamento do paciente}

Observou-se, no fornecimento gratuito e subsidiado de medicamentos um fator de empoderamento do paciente que pode ser exemplificado pela declaração da entrevistada residente na Comunidade da Mangueira: "Morrer, minha filha, quero morrer normal, mas por relaxamento, não. Que hoje em dia, eles falam mal do governo, mas eles falam, mas a gente morre de pressão alta, diabetes, dessas coisas, de relaxamento. Que o remédio tem, pra todo mundo, chega no posto, tem”.

\subsection{Conclusão final}

Não tem ninguém pra me explicar, né? PACIENTE CRÔNICA MORADORA DA MANGUEIRA, AO SER QUESTIONADA SE TINHA ALGUMA DÚVIDA A RESPEITO DE, MEMSO REALTANDO ADESÃO AO TRATAMENTO, SUA PRESSĨO CONTINUAR ALTA

O presente estudo apresenta limitações inerentes às entrevistas realizadas nas instalações hospitalares (entrevistas não diretivas), porém os resultados desta etapa foram concordantes com os dos demais métodos utilizados (questionários e entrevistas não-diretivas) realizados em outros ambientes. Entrevistar os pacientes no ambiente hospitalar foi uma das dificuldades enfrentadas no desenvolvimento desta pesquisa e, por este motivo, procurou-se outras opções para a realização das entrevistas. Esta alteração, no entanto, mostrou-se enriquecedora. Efetivamente, foi nas entrevistas realizadas na comunidade da Mangueira, na residência dos entrevistados, que se pode obter maior diversidade de dados e aprofundamento das questões propostas. Considera-se que a oportunidade poderia ter sido mais explorada, com registros fotográficos de melhor qualidade.

A presente pesquisa, ao trazer para o campo da Design elementos relativos ao campo da Assistência Farmacêutica, foi uma experiência desafiadora. A abordagem da Ergonomia é o fundamento deste trabalho, que, com foco no ser humano e suas necessidades, procura colaborar para um ambiente mais adequado aos seus usuários. É enriquecedora e gratificante a possibilidade de relacionar a Ergonomia e o Design com a Assistência Farmacêutica. 
Considera-se que os objetivos propostos, de levantar dados a respeito da dos problemas presentes comunicação no ciclo utilização de medicamentos e identificar a rotina do usuário para lidar com esses problemas, foram atingidos.

A partir da aplicação e análise dos três métodos de investigação com pacientes crônicos - levando-se em conta os limites da pesquisa descritiva, apresentada no delineamento da pesquisa - confirmou-se a relação causal, apresentada na hipótese, de que problemas na comunicação presentes no ciclo de utilização de medicamentos no tratamento de enfermidades crônicas prejudicam a autoadministração consciente dos medicamentos por pacientes crônicos/seus acompanhantes.

Conclui-se que a assistência farmacêutica, - política de saúde pública (BRASIL, 1998) composta de um conjunto de ações voltadas à promoção, proteção e recuperação da saúde, tanto individual como coletiva, tendo o medicamento como insumo essencial e visando ao acesso e uso racional do medicamento - não vem atingindo este objetivo.

Apesar do acesso ao medicamento, não vem ocorrendo o acesso ao tratamento com medicamentos. Isto se dá, conforme observado ao longo da presente pesquisa, devido a problemas ergonômicos, ou seja, problemas na comunicação entre os pacientes (usuário) e demais elementos do sistema: prescritores, dispensadores e outros elementos da comunicação presentes neste ciclo.

Este fato é de grande relevância uma vez que o controle das enfermidades crônicas é crucial para a viabilidade do serviço de saúde no panorama do envelhecimento populacional que vem ocorrendo no Brasil.

Soma-se a este fator o fato dos pacientes com maior número de morbidades serem também os mais vulneráveis (mais velhos, com menos acesso aos serviços de saúde, e com menor índice de escolaridade) e os mais afetados pelas enfermidades crônicas. 
Teixeira e Lefévre (2001) afirmam que "buscar entender a prescrição medicamentosa sob a ótica do paciente idoso é tentar compreender em profundidade o verdadeiro significado desse relacionamento, proporcionando medidas efetivas para melhorar o beneficio da terapêutica prescrita.”. O perfil das participantes nas entrevistas focadas apresenta semelhança com o perfil de usuários pertencentes à maior parcela de doentes crônicos e que se encontram em situação de maior vulnerabilidade devido aos fatores apresentados na pesquisa, sobretudo os da idade e escolaridade. Portanto, arriscamos afirmar que os resultados obtidos podem representar semelhanças com os enfrentados por essa população.

Observa-se a relevância das estratégias adotadas pelos usuários como referência para estudos posteriores ou estratégias no aprimoramento da utilização de medicamentos por pacientes crônicos.

Ainda a esse respeito, vale chamar a atenção para os elementos cotidianos utilizados na tarefa da administração de medicamentos e a relevância dos fatores estéticos/simbólicos presentes nas comunicação e compreensão do paciente a respeito do tratamento com medicamentos.

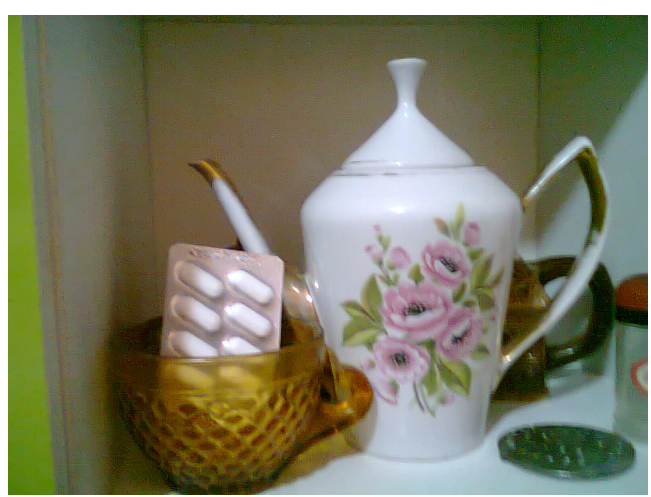




\section{Referências bibliográficas}

AKASHI et al. Tratamento anti-hipertensivo. Prescrição e custo de medicamentos. Pesquisa em hospital tercário. Arquivos brasileiros de cardiologia. v.71, n.1, p.55-57, 1998.

$\mathrm{AKICl}$, Ahmet et al. Patient knowledge about drugs prescribed at primary healthcare facilities. Pharmacoepidemiology and Drug Safety. v.13, n.12, p. $871-876$, dezembro. 2004

ALBERT, Nancy M. Improving Medication Adherence in Chronic Cardiovascular Disease. Critical care nurse. v. 28 , n.5, p. 54 , outubro. 2008.

ALFRADIQUE Maria E. et al. Internações por condições sensíveis à atenção primária: a construção da lista brasileira como ferramenta para medir o desempenho do sistema de saúde (Projeto ICSAP - Brasil). Cad. Saúde Pública, Rio de Janeiro. v.25, n.6, p.1337-1349, junho. 2009

ALMEIDA, Lucio M. Da prevenção primordial à prevenção quaternária. Revista portuguesa de saúde pública, v.31, n.1. janeiro/junnho. 2005.

ALMEIDA, Lucio M. Os serviços de saúde pública e o sistema de saúde. Revista portuguesa de saúde pública. v.28, n.1, p. 351-353. janeiro/junnho. 2010.

ALMEIDA, Márcia F. et al. Prevalência de doenças crônicas auto-referidas e utilização de serviços de saúde. Ciência \& Saúde Coletiva. v.7, n.4, p.743-756. 2002

ALVEZ-MAZZOTI, Alda Judith \& GEWANDSZNAJDER, Fernando. O Método nas ciências naturais e sociais: Pesquisa quantitativa e qualitativa. São Paulo: Editora Pioneira, 1999.

AMC Cancer Ressearch Center. Beyond the brochure: alternative approaches to affective health communication. Denver (Colorado): AMC Cancer Research Center, 1994.

ANACLETO, Tânia A. et al. Medication errors and drug-dispensing systems in a hospital pharmacy. Clinics, São Paulo, v.60, n.4, ago.2005. Disponível em: $\quad$ http://www.scielo.br/scielo.php?script=sci_arttext\&pid=S180759322005000400011\&lng=pt\&nrm=iso >. Acesso em: 10 fev. 2012.

ANSARI, Z.; LADITKA, J. N., LADITKA, S.B. Access to health care and hospitalization for ambulatory care sensitive conditions. Medical Care Research and Review. v.63, p719-741, 2006.

ASSOCIAÇÃO BRASILEIRA DE NORMAS TÉCNICAS. NBR 10520: Informação e documentação - Citações em documentos - Apresentação. Rio de Janeiro: Associação Brasileira de Normas Técnicas, agosto, 2002. 
ASSOCIAÇÃO BRASILEIRA DE NORMAS TÉCNICAS. NBR 6023: Informação e documentação - Referências - Elaboração. Rio de Janeiro: Associação Brasileira de Normas Técnicas, agosto, 2002.

ASSOCIAÇÃO BRASILEIRA DE NORMAS TÉCNICAS. NBR 6023: Informação e documentação - Referências - Elaboração. Rio de Janeiro: Associação Brasileira de NOrmas Técnicas, agosto, 2002.

AZAMBUJA, Maria Inês R. et al. Impacto Econômico dos Casos de Doença Cardiovascular Grave no Brasil: uma Estimativa Baseada em Dados Secundários. Arquivos brasileiros de cardiologia. v.91, n.3, p.163-171, 2008.

BARBOSA J. B. et al. Doenças e agravos não-transmissíveis: bases epidemiológicas. In: ROUQUAYROL, M.Z.; ALMEIDA FILHO, N. Epidemiologia \& saúde, 6. ed. Rio de Janeiro, 2003.

BARDIN, Lurence. Análise de conteúdo. Lisboa: Edições 70, 1979.

BARROS, Marilisa de A. B. Desigualdades sociais na prevalência de doenças crônicas no Brasil, PNAD-2003. Ciência \& saúde coletiva, Rio de Janeiro, v.11, n.4, dezembro. 2006.

BEASLEY, John A.; ESCOTO, Kamisha H. E; KARSH, Ben-Tizion. Human factors and ergonomics in primary care. In: CARAYON, Pascale (Ed.). Handbook of human factors in health care and patient safety. Mahwah, New Jersey: Lawrence Erlbawn Associates, 2007. p. 921-935.

BERGESON, Steven C.; DEAN, John D. A systems approach to patientcentered care. JAMA. v.296, n.23, p. 2848-2851, dezembro. 2006.

BERMUDEZ D, Baker L. The relationship between SCHIP enrollment and hospitalizations for ambulatory care sensitive conditions in California. Journal of health care for the poor and underserved. v.16, p.96-110, 2005.

BIBLIOTECA VIRTUAL EM SAÚDE. Descritores em ciências de Saúde. Disponivel em: http://decs.bvs.br/cgibin/wxis1660.exe/decsserver/?IsisScript=../cgi-

$\mathrm{bin} /$ decsserver/decsserver.xis\&interface_language $=p \&$ previous_page=hom epage\&previous_task=NULL\&task=start. Acesso em: 26 jan 2012.

BODENHEIMER, Thomas et al. Patient self-management of chronic disease in primary care. JAMA, v.288. n.19, p.2469-2475, 2002.

BODENHEIMER, Thomas; GRUMBACH Kevin. Improving Primary Care for Patients with Chronic Illness. In: Improving Primary Care: Strategies and Tools for a Better Practice. New York: McGraw-Hill, 2007. P.55-77.

BODENHEIMER, Thomas; GRUMBACH Kevin. Patient-Centered Care: Finding the Balance. In: Improving Primary Care: Strategies and Tools for a Better Practice. New York: McGraw-Hill, 2007. P.37-53. 
BODENHEIMER, Thomas; MACGREGOR, Kate; SHAFIRI, Claire. Helping Patients Manage Their Chronic Conditions. Oakland, California: California HealthCare Foundation; Jun. 2005.

BODENHEIMER, Thomas; WAGNER, Edward H.; GRUMBACH, Kevin. Improving primary care for patients with chronic illness. JAMA, v.288, n.14, p.1775-1779, outubro 9, 2002.

BRADDOCK, Clarence $\mathrm{H}$. et al. Informed decision making in outpatient practice time to get back to basics. JAMA. v. 202, n.24, p.2313-2320, dezembro 22/29, 1999.

BRANIN, Joan J. The role of memory strategies in medication adherence among the elderly. Home health care services quarterly, v.20, n.2, p.116, 2001.

BRASIL, Ministério da Saúde. Portaria $n^{\circ}$ 3.916/MS/GM, de 30 de outubro de 1998. Dispõe sobre a aprovação da Política Nacional de Medicamentos. Brasília: Ministério da Saúde, 1998

BRASIL. Ministério da Saúde. A vigilância, o controle e a prevenção das doenças crônicas não transmissíveis: DCNT no contexto do Sistema Único de Saúde brasileiro. Ministério da Saúde, Secretaria de Vigilância em Saúde, Departamento de Análise de Situação de Saúde. Brasília: Ministério da Saúde, 2005.

BRASIL. Ministério da Saúde. Declaração brasileira para a prevenção e controle das doenças crônicas não transmissíveis. Brasília: Ministério da Saúde, 2011. Disponível em : < http://portal.saude.gov.br/portal/arquivos/pdf/ratificacao_declaracao_2011.p df>. Acesso em 19 set. 2012.

BRASIL. Ministério da Saúde. Declaração brasileira para a prevenção e controle das doenças crônicas não transmissíveis. Brasília: Ministério da Saúde, 2011.

BRASIL. Ministério da Saúde. Farmácia popular do brasil. Disponível em <http://portal.saude.gov.br/portal/saude/area.cfm?id_area=1095> Acesso em 14 ago. 2012.

BRASIL. Ministerio de Saude. Glossário do Ministério da Saúde: projeto de terminologia em saúde / Ministério da Saúde - 1. ed., 2.a reimpr. Brasília: Ministério da Saúde, 2004.

BRASIL. Ministério da Saúde. Secretaria de Vigilância em Saúde, Departamento de Análise de Situação de Saúde. A vigilância, o controle e a prevenção das doenças crônicas não-transmissíveis: DCNT no contexto do Sistema Único de Saúde brasileiro / Brasil. Ministério da Saúde - Brasília: Organização Pan-Americana da Saúde, 2005.

BRASIL. Ministério da Saúde. Secretaria de Vigilância em Saúde. Departamento de Análise de Situação de Saúde. Plano de ações estratégicas para o enfrentamento das doenças crônicas não transmissíveis (DCNT) no Brasil 2011-2022 / Ministério da Saúde. Secretaria de Vigilância em Saúde. Departamento de Analise de Situação de Saúde. Brasília: Ministério da Saúde, 2011. 
BUCKLE Peter, CLARKSON PJ, COLEMAN R; et al. Systems mapping workshops and their role in understanding medication errors in healthcare. Applied Ergonomics. 2010 Sep; 41(5):645-56. Epub 2010 Feb 2.

CARAYON, Pascale. Human factors and ergonomics. In: Handbook of human factors and ergonomics in health care and patient safety. Mahwah, New Jersey: Lawrence Erlbawn Associates, 2007. p. 3-19.

CARAYON, Pascale; BUCKE, Peter. Editorial for special issue of applied ergonomics on patient safety. Applied Ergonomics. v.41, p. 643-644, 2010.

Casanova C, Starfield B. Hospitalizations of chidren and access to primary care: a cross-national comparison. International Journal of Health Services, v.25, p. 283-294, 1995

CERVO, A.R. BERVIAN, P. A. Metodologia Científica. 5a edição. São Paulo: Prentice Hall, 2002.

CLINICAL HUMAN FACTORS GROUP. Hwo we are. Disponível em: < http://www.chfg.org>. Acesso em 1 out. 2012.

COMMITTEE ON QUALITY OF HEALTH CARE IN AMERICA, Institute of Medicine. Crossing the quality chasm: a new health system for the $21 \mathrm{st}$ century. Washington D.C.: National Academy press, 2001.

CRUCIOL-SOUZA, JM; THOMSON, J; CATISTI, DG. Avaliação de prescrições medicamentosas de um hospital universitário brasileiro. Rev. Bras. Educ. Med., Rio de Janeiro, v.32, n.2, jun.2008. Disponível em:<http://www.scielo.br/scielo.php?script=sci_arttext\&pid=S010055022008000200006\&lng=pt\&nrm=iso>. Acesso em: 10 fev. 2012.

CUNHA, Maria Beatriz Assunção Mendes da. Perfil Sócio Econômico das Favelas da Cidade do Rio de Janeiro. Instituto dos estudos de trabalho e sociedade.

Disponível em: http://www.iets.org.br/biblioteca/Perfil_socio_economico_das_favelas_da_ Cidade_do_Rio_de_Janeiro.pdf. Acesso em: 24 jan.2012.

DEBER, Raisa B. The patient-physician partnership: changing roles and the desire for information. Canadian Medical Association Journal, v.151, p.171-176, 1994.

DELIA, D. Distributional Issues in the Analysis of Preventable Hospitalizations Health Serv Res. 2003 December; 38(6 Pt 2): 1761-1780.

DUBOIS, Carl-Ardy; SINGH, Deddie; JIWANI, Izzat. The human resource challenge in chronic care. In: Nolte, E; McKee, M. Caring for people with chronic conditions: A health system perspective. Berkshire: Open University Press, 2008.

ETCHELLS, Edward; JUURLINK, David; Levinson, Wendy. Medication errors: the human factors. Canadian Medical Association Journal, v.178, n.1, p.63-64, janeiro, 2008. 
FLEMING, Steven T. Primary care, avoidable hospitalization, and outcomes of care: a literature review and methodological approach. Medical care research and review. v.52, p.88-108, março, 1995

FROSCH, Dominick L.; KAPLAN, Robert M. shared decision making in clinical medicine: past research and future direction. American journal of preventive medicine, v.17, n.4, p.285-294, 1999.

GANDHI Tejal K. et al. Drug complications in outpatients. Journal of General Internal Medicine, v.15, n.3, p. 149-154, março, 2000

GLASGOW, Russell E.; ANDERSON Robert M. In diabetes care, moving from compliance to adherence is not enough. Diabetes care, v.22, n.12, dezembro, 1999.

GRESSLER, Lori A. Introdução à pesquisa: projetos e relatórios. São Paulo: Edições Loyola, 2003.

HAMMOND, Amy; LAUGHERY, Kenneth R. Overview. In: Warnings and risk communication. Editores: Michael S. Wogalter, David M. DeJo e Kenneth R. Laughery. London: Taylor \& Francis, 1999 p.2-12

HIGGNET, Sue; LU, Jun. Space to care and treat safely in acute hospitals: recommendations from 1866 to 2008. Applied ergonomics, v.41, p.666$673,2010$.

HOLSTI, O. S. A computer content analysis program for analysing attitudes: the measurement of qualities and performance. In: GREBNER, $G$. The analysis of communication content, developments is scientific theories and computer techniques. Nova York: Willey, 1969

INSTITUTO BRASILEIRO DE GEOGRAFIA E ESTATÍSTICA. Análise dos resultados da projeção da população do Brasil. In: Estudos e pesquisas, n. 24, Projeção da população do Brasil por sexo e idade 1980-2050. Rio de Janeiro: IBGE, 2008. Disponível em: < http://www.ibge.gov.br/home/estatistica/populacao/indic_sociosaude/2009/i ndicsaude.pdf >. Acesso em: 13 jan 2012.

INSTITUTO BRASILEIRO DE GEOGRAFIA E ESTATÍSTICA. A dinâmica demográfica brasileira e os impactos nas políticas públicas. In: Estudos e pesquisas, n.25, Indicadores sociodemográficos e de saúde no Brasil. Rio de Janeiro: IBGE, 2009. Disponível em: < http://www.ibge.gov.br/home/estatistica/populacao/indic_sociosaude/2009/i ndicsaude.pdf $>$. Acesso em: 12 jan 2012.

INSTITUTO BRASILEIRO DE GEOGRAFIA E ESTATÍSTICA. Acesso e Utilização de Serviços de Saúde. In: Pesquisa nacional por amostra de domicílios: acesso e utilização de serviços de saúde, 2003. Rio de Janeiro: IBGE, 2005. Disponível em: < http://biblioteca.ibge.gov.br/visualizacao/monografias/GEBIS\%20-

\%20RJ/acessosaude/Brasil_2003.pdf>. Acesso em 20 set. 2012.

INTERNATIONAL ERGONOMICS ASSOCIATION. Definition of Ergonomics. International Ergonomics Association, 2000. Disponível em <http://www.iea.cc/01_what/What\%20is\%20Ergonomics.html >. Acesso em 22 jul. 2012. 
INTERNATIONAL ORGANIZATION FOR STANDARDIZATION. ISO 5708. Information processing - Documentation symbols and conventions for data, program and systems flowcharts, program network charts and system resources charts. Geneva: International Organization for Standardization, 1985

KARSH, Ben Tzion; BROWN, Roger. Macroergonomics and patient safety: the impactof levels on theory, measurement, analysis andintervention in patient safety research. Applied ergonomics, v.41, p.674-681, 2010.

KAWANO, D. F. et al. Acidentes com os medicamentos: como minimizálos? Rev. Bras. Ciênc. Farm., São Paulo, v.42, n.4, dez.2006. Disponível em: $\quad$ http://www.scielo.br/scielo.php?script=sci_arttext\&pid=S151693322006000400003\&lng=pt\&nrm=iso >. Acesso em: 10 fev. 2012.

KINCAID, Lauence. Convergency theory. In: Encyclopedia of communication theory. Editores gerais: Stephen W. Littlejohn \& Karen A. Foss. Thousand Oaks: SAGE Publications Inc, 2009.

KRISTEVA, Julia. História da linguagem. Lisboa: Edições 70, 1969.

KRIPALANI, Sunil; HENDERSON, Laura E.; CHIU, Ellen Y.; ROBERTSON, Rashanda; KOLM, Paul; JACOBSON, Terry A. Predictors of Medication Self-management Skill in a Low-literacy Population Christiana Care Center for Outcomes Research, Newark, DE, USA.J Gen Intern Med. 2006 August; 21(8): 852-856.

LA FORGIA GM; HARDING, A. Public-private partnerships and public hospital performance in São Paulo, Brazil. Health Aff (Millwood), v.28, n.4, p.1114-1126, 2009

LAVILLE, Antoine. Ergonomia.Tradução: Márcia Maria Neves Teixeira. São Paulo: EPU, 1977.

LEAPE, Lucian. Huma Factors meets health care: The ultimate Challange. In: Ergonomics in design: The quaterly of human factors applications. v.12, n.6, p. 5-12. Summer, 2004.

LICHT, D. M., POLZELLA, D. J.; BOFF, K. R.. Human factors, ergonomic, and human factors engineering: An analysis of definitions. Paper presented at the American Psychological Association (APA), New York. (Manuscript copy available from CSERIAC, Dayton, Ohio).Human Factors, Ergonomics, and Human Factors Engineering: An Analysis of Definitions, 1990.

LIMA, Vera L. de A. Legibilidade e leiturabilidade das bulas de medicamentos presentes no tratamento de pacientes cardíacos. Dissertação (Mestrado em Artes e Design) - orientadora: Anamaria de Moraes. Rio de Janeiro: Pontifícia Universidade Católica do Rio de Janeiro, 2007.

LORIG, K. Self-management of chronic illness: a model for the future. Generations. V.17, n.3, p.11-14, fall, 1993 
MACINKO, J. et al. The influence of primary care and hospital supply on ambulatory care-sensitive hospitalizations among adults in Brazil, 19992007. American Journal of Public Health. v.101, n.10, out. 2011.

MALTA, Debora C.; MERHY, Emerson E. O percurso da linha do cuidado sob a perspectiva das doenças crônicas não transmissíveis. Interface (Botucatu), v.14, n.34 p.593-605, Epub Sep 17, 2010. Disponível em: <http://www.scielo.br/pdf/icse/2010nahead/aop0510.pdf>. Acesso em 22 set. 2012.

MARZIALE, Maria H. P.; CARVALHO, Emília .C.de. Condições ergonômicas do trabalho da equipe de enfermagem em unidade de internação de cardiologia. Revista latino-americana de enfermagem. Ribeirão Preto, v. 6, n. 1, p. 99-117, janeiro 1998.

MENEZES, E. Diatay B. de. O processo da comunicação humana: modelos. In: SÁ, Adísia (Coordenadora). Fundamentos científicos da comunicação. Petrópolis: Vozes, 1978. P. 151-171.

MOEHLECKE, Renata. Pesquisa com 3 mil idosos indica alta prevalência de uso de medicamentos. Agencia Fiocruz de Notícias. Publicado em 6/8/2012. Disponível em: $<$ http://www.fiocruz.br/ccs/cgi/cgilua.exe/sys/start.htm?infoid=4762\&sid=9> Acesso em 22 set. 2012.

MONTMOLLIN, Maurice D. Introduccion a la Ergonomia. Madrid: Aguilar, 1971.

MORAES, Anamaria. A ergonomia e a minimização do ruído comunicacional no trabalho. Rio de janeiro: Laboratório de Ergonomia e Usabilidade de Interfaces em Sistemas Homem-Tecnologia PUC-Rio Pontifícia Católica do Rio de Janeiro, [1994-2003].

MORAES, Amamaria. SOARES, M. Ergonomia no Brasil e no mundo: um quadro, uma fotografia. Rio de Janeiro, Univerta/ ABERGO/ ESDIUERJ, 1989.

MORAES, Anamaria. Ergonomia Informacional: A comunicação humana tarefa-máquina: Processamento, convergência e mudanças de comportamento. In: Avisos, advertências e projetos de sinalização: Ergodesign informacional. Rio de Janeiro: IUser, 2002, p. 7-29.

MORAES, Anamaria. Tipos de pesquisa. In:_ Dagnóstico ergonômico do processo comunicacional do sistema homem-máquina de transcrição de dados: Posto de trabalho do digitador. Rio de Janreiro: UERJ, 1992. Tese. - Escola de Comunicação, Universidade do Estado do Rio de Janeiro, Rio de Janeiro, 1992.

MOREAS, Amamaria; MONT'ALVÃO, Claudia M. Ergonomia: Conceitos e Aplicações. Rio de Janeiro: 2AB, 2009.

MORAES, Anamaria; SOAERS, Marcelo M. Ergonomia no Brasil e no Mundo: um quadro, uma fotografia. Rio de Janeiro: UNIVERTA / Abergo Associação Brasileira de Ergonomia,1989. 
MORROW, Daniel G.; LEIRER, Von O., ANDRASSY, Jill M. Using icons to convey medication schedule information. Applied ergonomics. v.27, n.4, p.267-275, 1996.

MUCCHIELLI, Roger. A entrevista não-diretiva. Rio de Janeiro: Martins Fontes, 1978a.

MUCCHIELLI, Roger. L'analyse de contenu des documents et des communications, Paris, co-ed. ESF E.M.E, Lib. Tech., 1982.

MUCCHIELLI, Roger. O questionário na pesquisa psicossocial. Rio de Janeiro: Mrtins Fontes, 1979

MUCCHIELLI, Roger. Opinion e changement d'opinion: Connaissance du probbléme Paris: Libraries Techniques, Eterprise Moderne 'editionet les Editions sociales françaises, 1969.

Nedel F B. et. al. Family Health Program and ambulatory care-sensitive conditions in Southern Brazil. Revista de Saúde Pública. v.42, p1034 a 1040, 2008.

NOLTE, Ellen e MCKEE, Martin. Caring for people with chronic conditions: an introduction. In: Caring for People with Chronic Conditions: A Health System Perspective. Berkshire: Open University Press, 2008a.

NOLTE, E e MCKEE, M. Integration in Chronic Care: A Review. In:

Caring for People with Chronic Conditions: A Health System Perspective. Berkshire: Open University Press, 2008b.

OLIVEIRA, Alessandra C.; SIMÕES, Rodrigo F.; ANDRADE, Mônica V. A relação entre a atenção primária à saúde e as internações por condições sensíveis à atenção ambulatorial nos municípios mineiros. Textos para Discussão Cedeplar-UFMG. Disponível em: http://www.econbiz.de/en/search/detailed-view/doc/relação-entre-atençãoprimária-à-saúde-internações-por-condições-sens \%C3\%ADveis-à-atençãoambulatorial-nos-munic\%C3\%ADpios-mineiros-oliveira-alessandracoelho/10008518335/. Acesso em: 24 jan. 2012.

OLIVEIRA, Giuseppe A. de. Ergonomia informacional na travessia de pedestre. Tese (Doutorado em Artes e Design) - orientadora: Anamaria de Moraes. Rio de Janeiro: Pontifícia Universidade Católica do Rio de Janeiro, 2009.

OLIVEIRA, Maria A.; BERMUDEZ, Jorge A.Z.; OSÓRIO DE CASTRO, Claudia G.S. Assistência farmacêutica e acesso a medicamentos. Rio de Janeiro: Fiocruz, 2007.

ORGANIZAÇÃO MUNDIAL DE SAÚDE. Adherence to long-term therapies: Policy for action, Meeting Report 4-5 June 2001. Genebra: World Health Organization, 2001.

ORGANIZAÇÃO MUNDIAL DE SAÚDE. Chronic diseases. Disponível em: < http://www.who.int/topics/chronic_diseases/en/> Acesso em: 15 jan. $2012 a$.

ORGANIZAÇÃO MUNDIAL DE SAÚDE. Chronic diseases in low and middle income countries. Genebra: World Health Organization, 2005a. 
ORGANIZAÇÃO MUNDIAL DE SAÚDE. Human Factors in Patient Safety: review of topics and tools. Report for Methods and Measures Working Group of WHO Patient Safety. Genebra: 2009. Disponível em: $<$ http://www.who.int/patientsafety/research/methods_measures/human_fact ors/human_factors_review.pdf> Acesso em: 15 mar. 2012b.

ORGANIZAÇÃO MUNDIAL DE SAÚDE. Guia para a boa prescrição médica. Tradução de Cláudia Buchewietz. Porto Alegre: Artmed, 1998.

ORGANIZAÇÃO MUNDIAL DE SAÚDE. NCD Country Profiles, 2011Brazil. Disponível em: <http://www.who.int/nmh/countries/bra_en.pdf.>. Acesso em 28 jan. 2011.

ORGANIZAÇÃO MUNDIAL DE SAÚDE. Preventing chronic diseases: a vital investment. Geneva: World Health Organization, 2005b.

ORGANIZAÇÃO MUNDIAL DE SAÚDE. The global burden of disease: 2004 update. Genebra: World Health Organization, 2008a.

ORGANIZAÇÃO MUNDIAL DE SAÚDE. Vigilância global, prevenção e controle das doenças respiratórias crônicas: Uma abordagem integradora. Tradução para a lingua portuquesa Tradução para língua portuguesa: CISCOS - Centro de Investigação em Saúde Comunitária. Lisboa: Organização Mundial de Saúde, 2007b.

OSÓRIO DE CASTRO, Claudia Garcia Serpa. Prescrição de medicamentos. Disponível em: http://www.ensp.fiocruz.br/portalensp/judicializacao/pdfs/516.pdf. Acesso em: 27 out 2011.

PARCHMAN M.L; CULLER S. Primary care physicians and avoidable hospitalizations. Journal Family Practice, v.39, p.123-128, 1994.

PAPPAS et al. Potentially Avoidable Hospitalizations: Inequalitiesin Rates between US Socioeconomic Groups. American Journal of Public Health. v.87, n.5, May, 1997,

PEPE, Vera L. E.; \& OSÓRIO DE CASTRO, Claudia G. S. A interação entre prescritores, dispensadores e pacientes: informação compartilhada como possível benefício terapêutico. Cadernos de Saúde Púbica. n.16, v.3, p.815-822, jul-set, 2000. Disponível em: <http://www.scielosp.org/pdf/csp/v16n3/2966.pdf.> Acesso em: 25 out. 2011.

PERPETUO, Ignez H. O. \& WONG, Laura R.. Atenção hospitalar por Condições Sensíveis à Atenção Ambulatorial (CSAA) e as mudanças no seu padrão etário: uma análise exploratória dos dados de Minas Gerais. Diamantina: XII Seminário sobre Economia Mineira, 2006.

PÓS-GRADUAÇÃO PUC-Rio. Normas para apresentação de teses e dissertações. / Pontifícia Univercidade Católica do Rio de Janeiro. Rio de Janeiro: PUC-Rio, Vice-Reitoria para Assuntos Acadêmicos, 2001.

RABAÇA, Carlos Alberto; BARBOSA, Gustavo. Comunicação. In: Dicionário de comunicação. São Paulo: Ática, 1987. 
REDE de pesquisa em atenção primária à saúde. III REUNIÃO ANUAL DA REDE DE PESQUISA EM APS: RELATÓRIO DAS ATIVIDADES. BRASÍLIA/DF 13 a 14 dez. 2010. Disponível em http://www.rededepesquisaaps.org.br/UserFiles/File/RelatoriofinallIIReunia o.pdf. Acesso em 24 jan. 2012.

RENDERS CM, et al. Interventions to improve the management of diabetes in primary care, outpatient, and community settings: a systematic review. Diabetes Care, v.24, n.10, p.1821-1833, 2001

RICHARDSON et al. Pesquisa Social: Métodos e Técnicas. 3 ed. São Paulo: Atlas. 2009.

RUDIO Frans V. Introdução ao projeto de pesquisa. Perópolis: Vozes, 1986

SANT'ANA, João M. B. et al. Racionalidade terapêutica: elementos médico-sanitários nas demandas judiciais de medicamentos Revista de Saúde Pública. v.45 n.4, 2011.

SANTOS, V dos; NITRINI, SM. Indicadores do uso de medicamentos prescritos e de assistência ao paciente de serviços de saúde. Rev. Saúde Pública, São Paulo, v. 38, n.6, 2004 . Disponível em: $<$ http://www.scielo.br/scielo.php?script=sci_arttext\&pid=S0034$89102004000600010 \&$ Ing=en\&nrm=iso>. Acesso em: 28 jan. 2012.

SCHMIDT, Maria Inês et al. Doenças crônicas não transmissíveis no Brasil: carga e desafios atuais. The Lancet Saúde no Brasil 4, 2011. Disponível em:

<http://download.thelancet.com/flatcontentassets/pdfs/brazil/brazilpor4.pdf > Acesso em: 24 jan 2012.

SHALOWITZ, David I.; WOLF, Michael S. Shared Decision-Making and the Lower Literate Patient. The Journal of Law, Medicine \& Ethics, v.32, n.4, p.759-764, winter, 2004.

SHANNON, Claude E. \& WEAVER, Waren. Recent contributions to the mathematical theory of communication. In: The Mathematical theory of communicatio. Urbana: University of Illinois Press, 1949, 1998.

SHRAMM, Wilbur. How communication works. In: The process and effects of mass communication. Urbana: University of Illinois Press, 1961.

SCHRAMM Joyce M. et al. Transicao epidemiologica e carga de doenca no Brasil. Ciência \& Saúde Coletiva, v.9, n.4, p.897-908, 2004

SMITH-JACKSON, Tonya; WOGALTER, Michael. Methods and procedures in warning research. In: Handook of warnings. Editor: Michael S. Wogalter. Manhaw, New Jersey. London: La wrence Erlbaum Assoiates, 2006 .

SILVA, Anderson L. et al. Utilização de medicamentos por idosos brasileiros, de acordo com a faixa etária: um inquérito postal. Cadernos de Saúde Púbica. n.28, v.6, p.1033-1045, jun, 2012. Disponível em:< http://www.scielo.br/pdf/csp/v28n6/03.pdf>. Acesso em 22 set. 2012. 
SMITH, Maurren A. e BARTELL, Jessica M. The relationship between physician professionalism and health care systems change. In: CARAYON, Pascale (Ed.). Handbook of human factors in health care and patient safety. Mahwah, New Jersey: Lawrence Erlbawn Associates, 2007. p. 139146.

ROZENFELD, Suely. Prevalência, fatores associados e mau uso de medicamentos entre os idosos: uma revisão. Cadernos de saúde pública, v.19, n.3, p.717-724, 2003

STEWART, M.; BROWN, JB., DONNER, A.; MCWHINNEY IR.; OATES, J; WESTON, WW; JORDAN, J. The impact of patient-centered care on outcomes. Journal of Family Practice v. 49, n. 9. Sept, 2000.

UNICEF. Cuidados primários de saúde: 30 anos desde Alma-Ata. Disponível em:< http://www.unicef.org/brazil/sowc9pt/cap2-dest2.htm>. Acesso em 22 set. 2012.

VAN DALEN, Deobold B.; MEYER, William J. Estrategia de la investigacion descriptiva. In: Manual de tecnica de la investigacion educacion sducacional. Tradução de Oscar Muslera e César Moyano. Buenos Aires: Editorial Paidós, 1971.

VINCENT, Charles et al. Systems approaches to surgical quality and safety from concept to measurement. Annals of Surgery, v.239, n. 4, April 2004.

WAGNER, Edward H. Does the Chronic Care Model Work? Slideshow of the Chronic Care Model and its Evidence Base Supporting information extracted from PowerPoint notes., 2007.

WAGNER, Edward $\mathrm{H}$.; et al. Improving Chronic Illness Care: Translating Evidence Into Action. Health Affairs, v.20, n.6, 2001.

WAGNER, Edwurd H. Parte 1. The chronic Care Model. Palestra apresentada no evento Epidemiology, Biostatistics and Clinical Research Methods Summer Session, 2004. Disponível em : http://www.improvingchroniccare.org/video/Model_Talk.html. Acesso em 30 jan 2012.

WARD, James; BUCKLE, Peter, CLARKSON, P. John. Designing healh care packaging to support the safe use of medicines at home. Applied ergonomics, v.41, p.682-694, 2010.

WILSON, John R. Fundamentals of ergonomics in theory and practice. In: Applied ergonomics, v.31, p.556-567, 2000.

WOGALTER, Michael S. Commuication-human information processing (CHIP) model. In: Handook of warnings. Editor: Michael S. Wogalter. Manhaw, New Jersey. London: La wrence Erlbaum Assoiates ,2006

WOGALTER, Michael S. Factors that influence the effectiveness of warning signs and Lables. In: Ergodesign/USIHC Coletânea de palestras de convidados internacionais e nacionais. Rio de Janeirio: IUser e Faperj, 2004 
WOGALTER, Michael S.; CONZOLA, Vincent C. A communication-human information processing (C-HIP) approach to waring effectivness in the workplace. In: Journal of risk research. v. 4 n. 4 p. 309-322. Taylor \& Francis, 2001

WOGALTER, Michael S.; DEJOY, David M.; LAUGHERY, Kenneth R. Organizing theorethical framework: A cosolidated communication-human information processing (C-HIP) model. In: Warnings and risk communication. Editores: Michael s. Wogalter, David M. DeJo e Kenneth R. Laughery. London: Taylor \& Francis, 1999 p. 13-21

WOGALTER, Michael S.; SOJOURNER, Russel J. Research on pharmaceutical labeling: An information processing approach. In D. C. Park, R. C. Morrell; K. Shifren (Eds.) Processing of Medical Information in Aging Patients: Cognitive and Human Factors Perspectives. (pp. 291310) Mahwah, NJ: Lawrence Erlbaum Associates.

WORLD HEALTH ORGANIZATION - WHO. Action plan for the global strategy for the prevention and control of noncommnunicable diseases: prevent and control cardiovascular diseases, cancers, chronic respiratory diseases and diabetes. Genebra: World Health Organization, 2008a. 
11 Apêndices 
168

Apêndice 1: questionário piloto

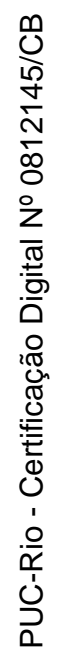



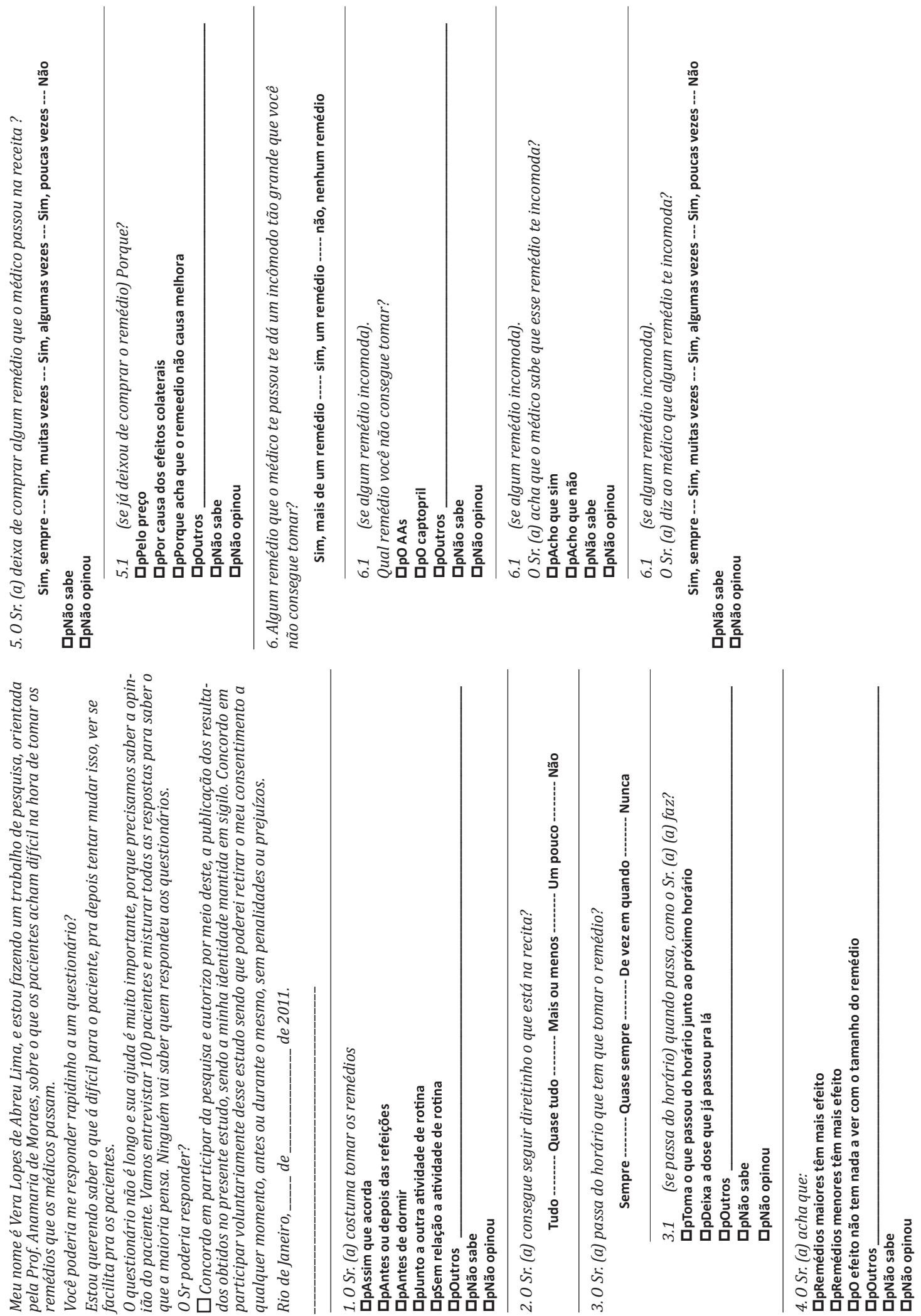


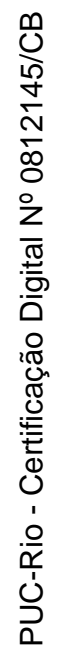
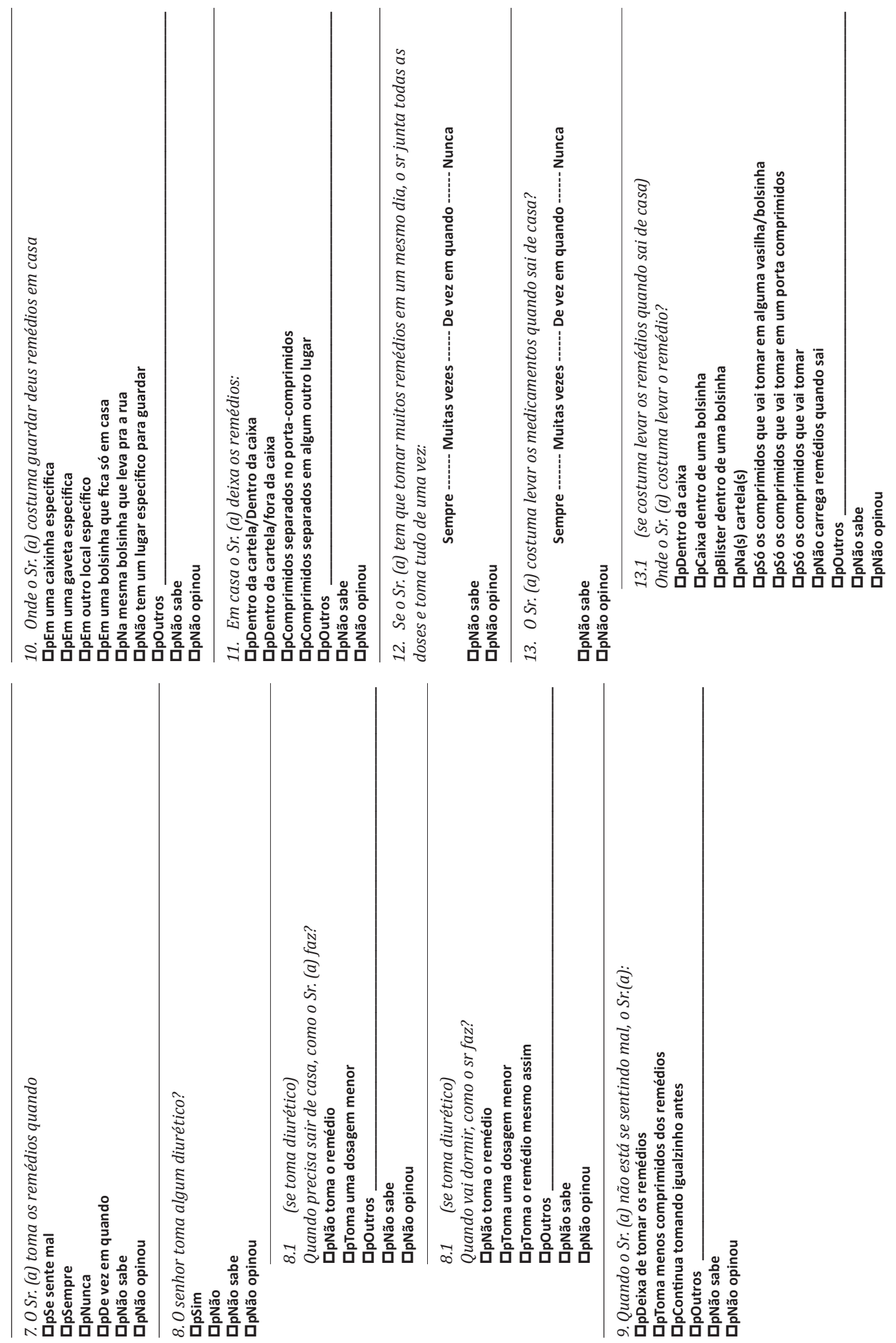

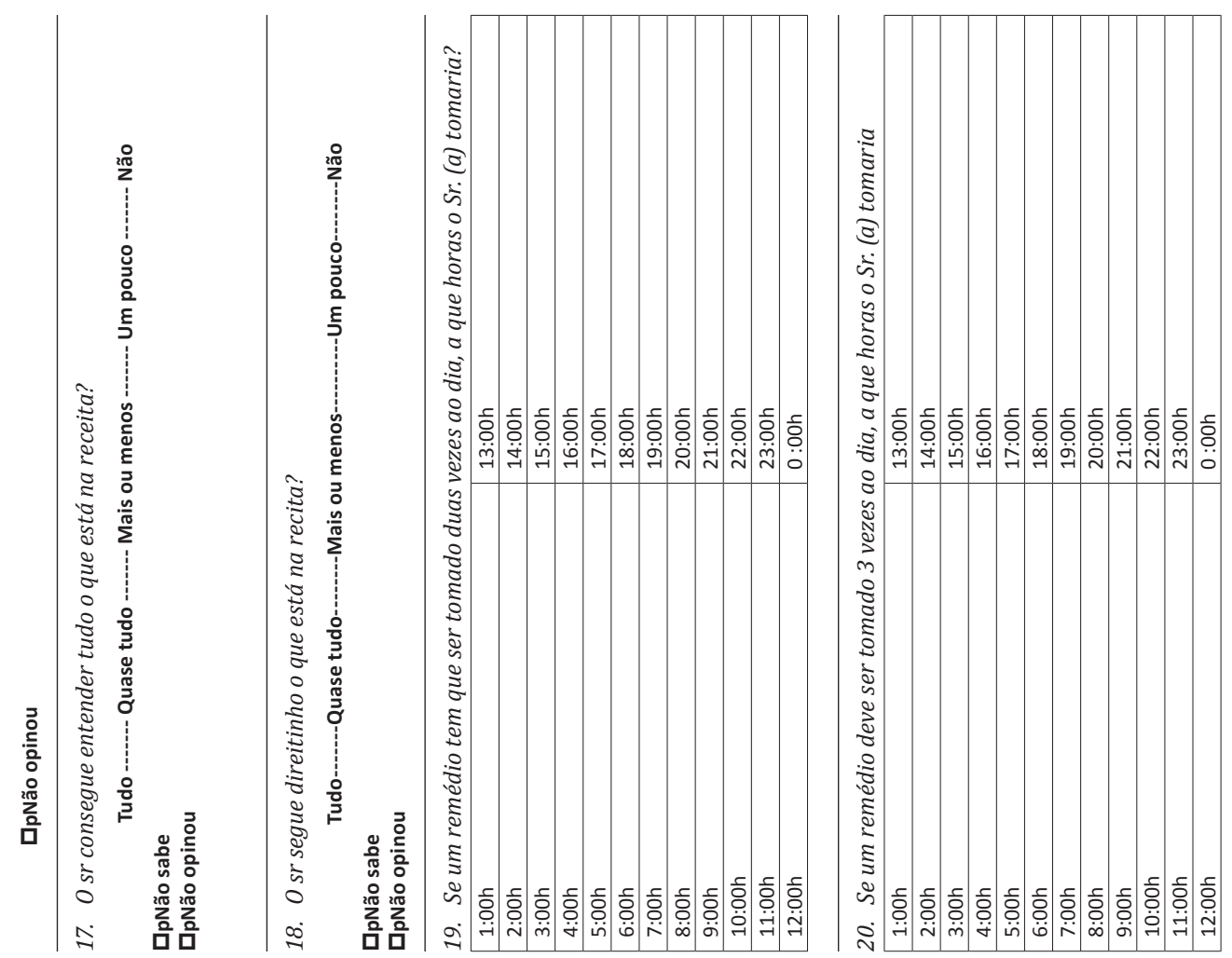

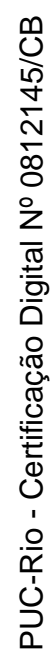

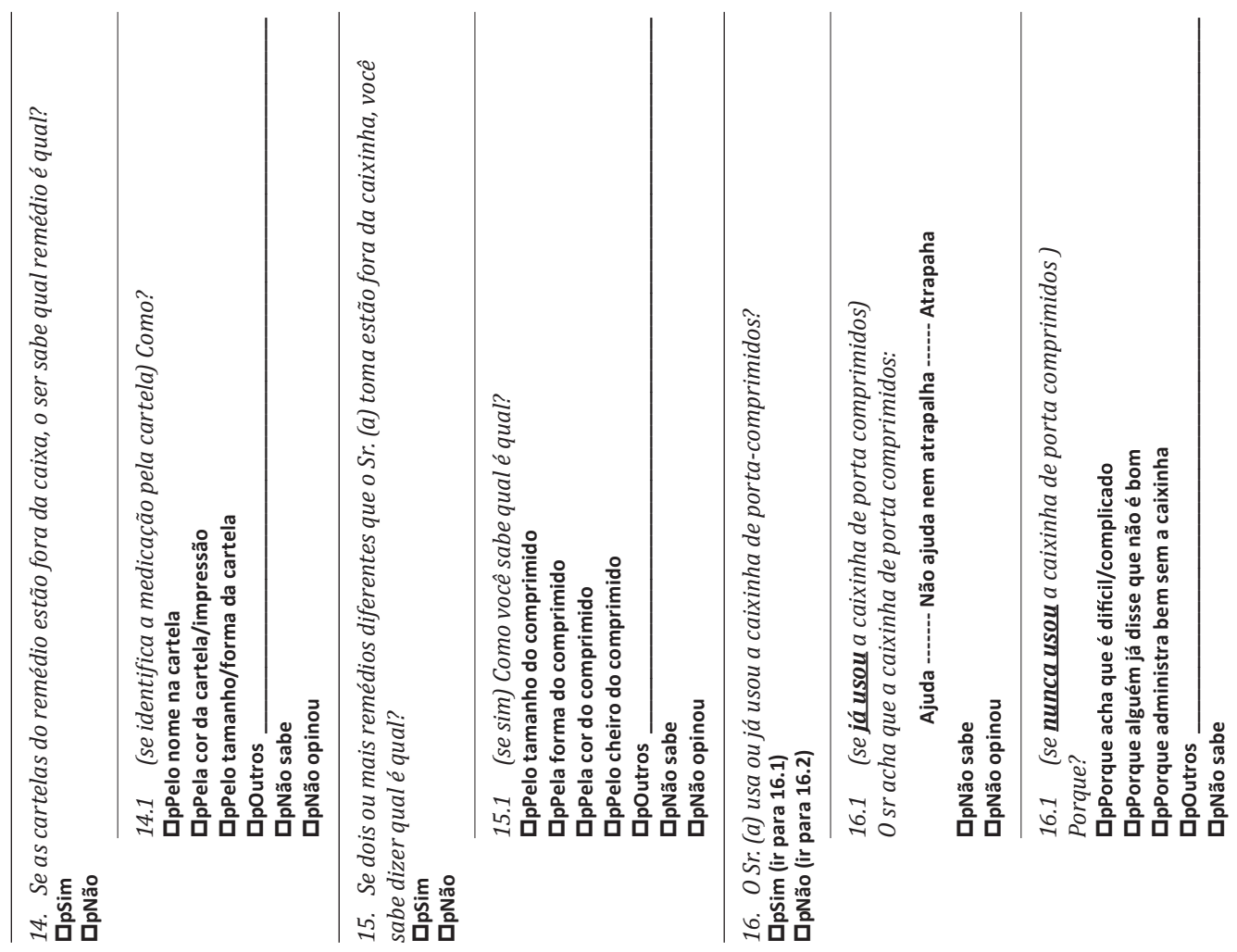



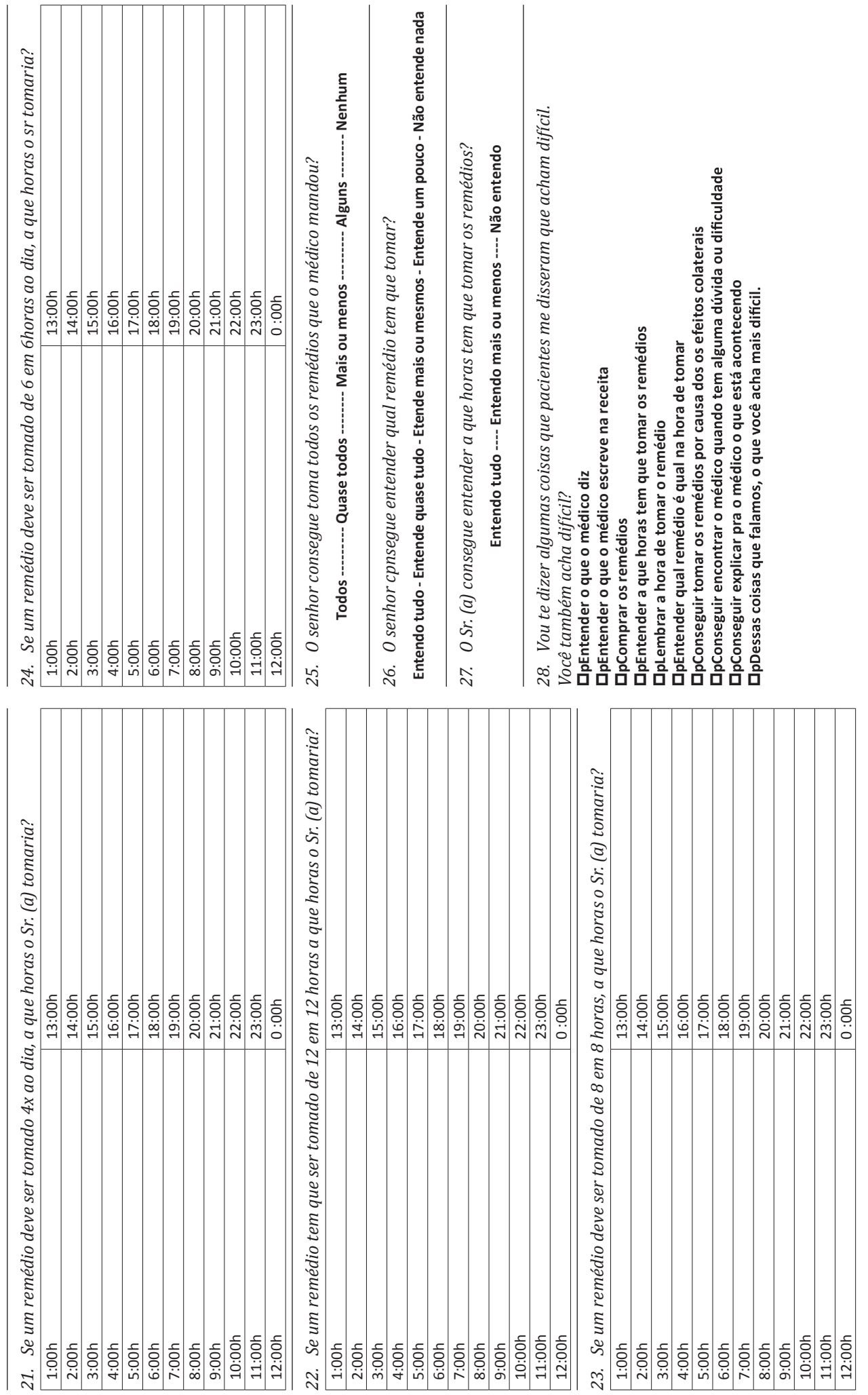


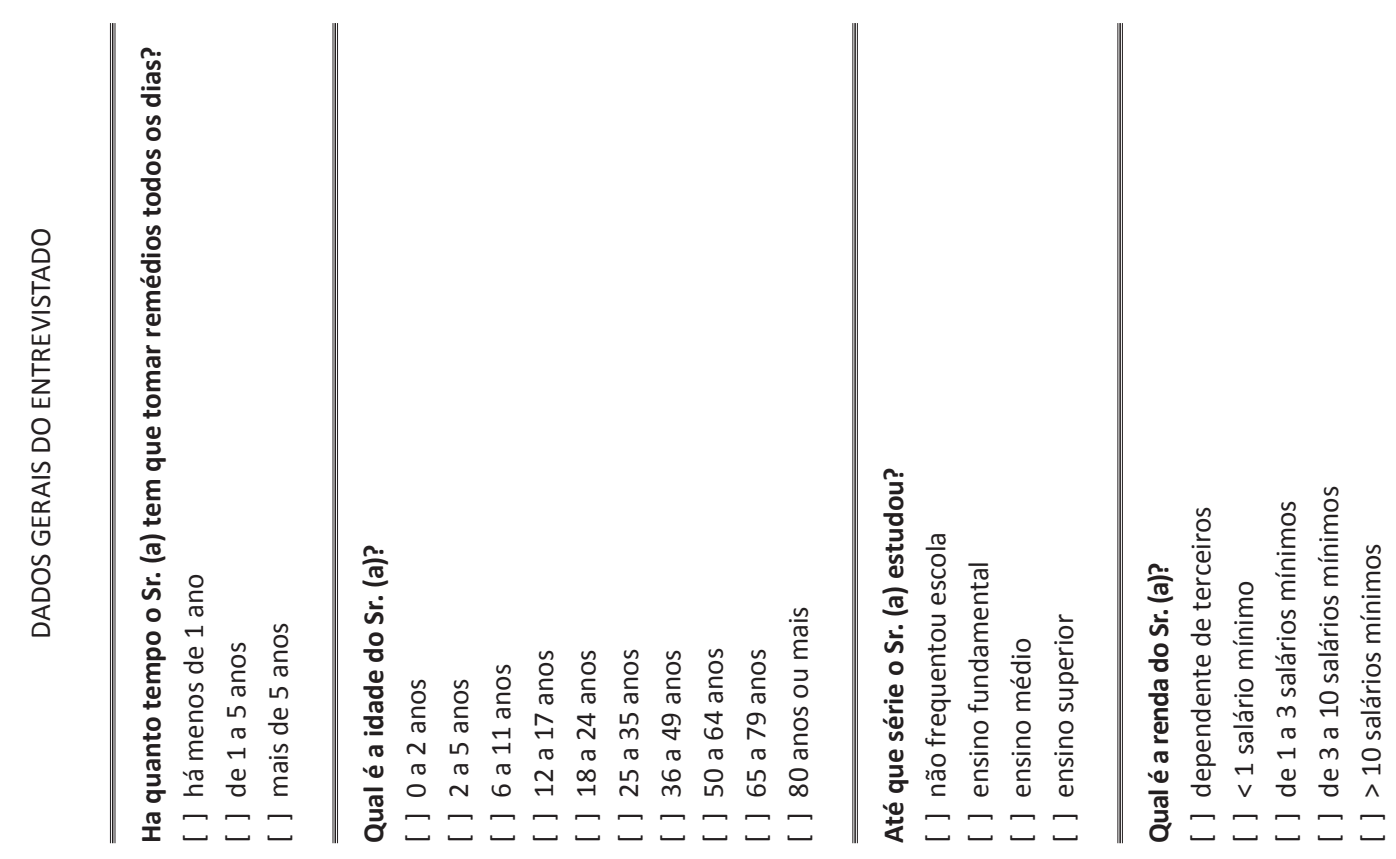

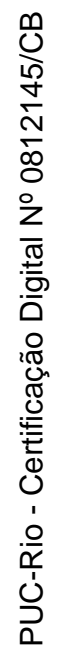

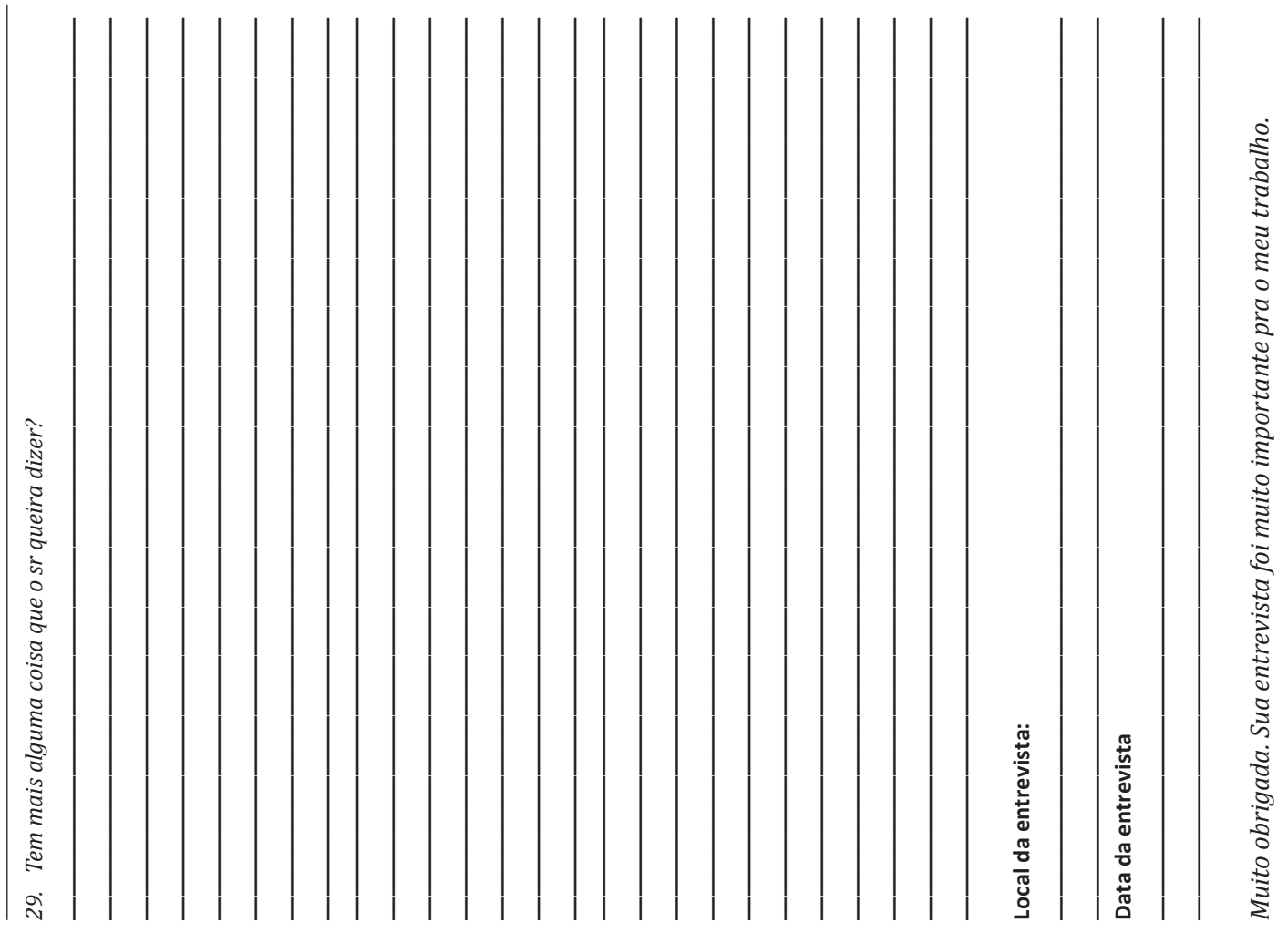


Apêndice 2: questionário final

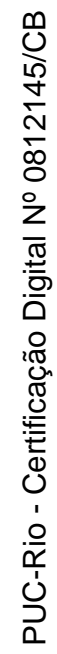




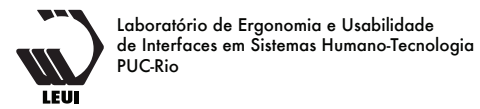

\section{Pontifícia Universidade Católica $_{\text {a }}$ DO RIO DE JANEIRO}

Meu nome é Vera Lopes de Abreu Lima, e estou fazendo um trabalho de pesquisa de doutorado na Puc-Rio, orientada pela Prof. Anamaria de Moraes, sobre como os pacientes se organizam para conseguir tomar os seus remádios e o que acham difícil.

0 questionário não é longo e sua ajuda é muito importante, porque precisamos saber a opinião do paciente. Vamos entrevistar 100 pacientes e misturar todas as respostas para saber o que a maioria pensa.

Ninguém vai saber quem respondeu aos questionários. 0 Sr. (a) poderia responder?

$\square$ Concordo em participar voluntariament e autorizo por meio deste, a publicação dos resultados obtidos no presente estudo, sendo a minha identidade mantida em sigilo. Poderei retirar o meu consentimento a qualquer momento, antes ou durante o mesmo, sem penalidades ou prejuízos.

Rio de Janeiro, de de 2011.

\begin{tabular}{|c|c|c|c|c|c|}
\hline \multicolumn{6}{|c|}{ 1. Quais medicamentos o Sr.(a) toma, e a que horas? } \\
\hline \multirow{3}{*}{ 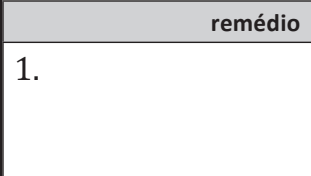 } & \multicolumn{5}{|c|}{ horário } \\
\hline & $\begin{array}{l}\text { पpao acordar } \\
\text { पpcafé da manhã }\end{array}$ & Dplanche de manhã & $\begin{array}{l}\text { Qpalmoço } \\
\text { पplanche da tarde }\end{array}$ & $\begin{array}{l}\text { पpjantar } \\
\text { Dpao deitar }\end{array}$ & $\begin{array}{l}\text { पpnão sabe } \\
\text { पpnão opinou }\end{array}$ \\
\hline & Dpoutros & & & & \\
\hline \multirow[t]{2}{*}{2.} & $\begin{array}{l}\text { पpao acordar } \\
\text { पpcafé da manhã }\end{array}$ & 口planche de manhã & $\begin{array}{l}\text { पpalmoço } \\
\text { पplanche da tarde }\end{array}$ & $\begin{array}{l}\text { पpjantar } \\
\text { पpao deitar }\end{array}$ & $\begin{array}{l}\text { पpnão sabe } \\
\text { पpnão opinou }\end{array}$ \\
\hline & Dpoutros & & & & \\
\hline \multirow[t]{2}{*}{3.} & $\begin{array}{l}\text { पpao acordar } \\
\text { पpcafé da manhã }\end{array}$ & Dplanche de manhã & $\begin{array}{l}\text { पpalmoço } \\
\text { पplanche da tarde }\end{array}$ & $\begin{array}{l}\text { Dpjantar } \\
\text { पpao deitar }\end{array}$ & $\begin{array}{l}\text { पpnão sabe } \\
\text { पpnão opinou }\end{array}$ \\
\hline & Dpoutros & & & & \\
\hline \multirow[t]{2}{*}{4.} & $\begin{array}{l}\text { पpao acordar } \\
\text { पpcafé da manhã }\end{array}$ & Dplanche de manhã & $\begin{array}{l}\text { पpalmoço } \\
\text { पplanche da tarde }\end{array}$ & $\begin{array}{l}\text { पpjantar } \\
\text { पpao deitar }\end{array}$ & $\begin{array}{l}\text { पpnão sabe } \\
\text { पpnão opinou }\end{array}$ \\
\hline & Dpoutros & & & & \\
\hline \multirow[t]{2}{*}{5.} & $\begin{array}{l}\text { पpao acordar } \\
\text { पpcafé da manhã }\end{array}$ & Dplanche de manhã & $\begin{array}{l}\text { पpalmoço } \\
\text { पplanche da tarde }\end{array}$ & $\begin{array}{l}\text { पpjantar } \\
\text { पpao deitar }\end{array}$ & $\begin{array}{l}\text { पpnão sabe } \\
\text { पpnão opinou }\end{array}$ \\
\hline & Dpoutros & & & & \\
\hline \multirow[t]{2}{*}{6.} & $\begin{array}{l}\text { पpao acordar } \\
\text { पpcafé da manhã }\end{array}$ & Dplanche de manhã & $\begin{array}{l}\text { पpalmoço } \\
\text { पplanche da tarde }\end{array}$ & $\begin{array}{l}\text { पpjantar } \\
\text { Dpao deitar }\end{array}$ & $\begin{array}{l}\text { पpnão sabe } \\
\text { पpnão opinou }\end{array}$ \\
\hline & Dpoutros & & & & \\
\hline \multirow[t]{2}{*}{7.} & $\begin{array}{l}\text { पpao acordar } \\
\text { पpcafé da manhã }\end{array}$ & Dplanche de manhã & $\begin{array}{l}\text { पpalmoço } \\
\text { Dplanche da tarde }\end{array}$ & $\begin{array}{l}\text { पpjantar } \\
\text { पpao deitar }\end{array}$ & $\begin{array}{l}\text { पpnão sabe } \\
\text { पpnão opinou }\end{array}$ \\
\hline & Dpoutros & & & & \\
\hline \multirow[t]{2}{*}{8.} & $\begin{array}{l}\text { पpao acordar } \\
\text { पpcafé da manhã }\end{array}$ & Dplanche de manhã & $\begin{array}{l}\text { पpalmoço } \\
\text { पplanche da tarde }\end{array}$ & $\begin{array}{l}\text { पpjantar } \\
\text { पpao deitar }\end{array}$ & $\begin{array}{l}\text { पpnão sabe } \\
\text { पpnão opinou }\end{array}$ \\
\hline & Dpoutros & & & & \\
\hline \multirow[t]{2}{*}{9.} & $\begin{array}{l}\text { पpao acordar } \\
\text { Dpcafé da manhã }\end{array}$ & 口planche de manhã & $\begin{array}{l}\text { पpalmoço } \\
\text { Dplanche da tarde }\end{array}$ & $\begin{array}{l}\text { Dpjantar } \\
\text { Dpao deitar }\end{array}$ & $\begin{array}{l}\text { पpnão sabe } \\
\text { ロpnão opinou }\end{array}$ \\
\hline & Dpoutros & & & & \\
\hline \multirow[t]{2}{*}{10.} & $\begin{array}{l}\text { पpao acordar } \\
\text { पpcafé da manhã }\end{array}$ & Dplanche de manhã & $\begin{array}{l}\text { पpalmoço } \\
\text { पplanche da tarde }\end{array}$ & $\begin{array}{l}\text { पpjantar } \\
\text { 口pao deitar }\end{array}$ & $\begin{array}{l}\text { पpnão sabe } \\
\text { पpnão opinou }\end{array}$ \\
\hline & Dpoutros & & & & \\
\hline
\end{tabular}


2.0 sr. (a) contuma seguir exatamente o que está na recita?

Tudo -------- Quase tudo -------- Mais ou menos -------- Um pouco -------- Não

3. Se o sr. (a) passa do horário que tem que tomar o remédio, como o sr. (a) faz?

$\square$ pDeixa a dose que já passou pra lá

口pToma a dose assim que se lembra

口pToma o que passou do horário junto ao próximo horário

$\square$ pNunca passa do horário

口pOutros

口pNão sabe

口pNão opinou

4. O sr. (a) já deixou de comprar algum remédio que o médico passou na receita?

口pNão

DpSim, um medicamento

$\square$ pSim, mais de um medicamento

$\square$ pNão sabe

口pNão opinou

4.1 (se já deixou de comprar) Porque?

DpPelo preço

口pPor causa dos efeitos colaterais

$\square$ pPorque acha que o remeedio não causa melhora

口pOutros

口pNão sabe

口pNão opinou

5. Algum remédio que o médico te passou já te deu um incômodo tão grande que você não conseguiu tomar?

Sim, mais de um remédio ----- sim, um remédio ----- não, nenhum remédio

5.1 (se algum remédio incomoda).

Qual remédio você não consegue tomar?

DpAAS

口pCaptopril

Dpsinvastatina

口pOutros

口pNão sabe

口pNão opinou

5.2 (se algum remédio incomoda).

0 médico sabe que esse remédio te incomoda?

口pSim

$\square$ pAcho que sim

口pNão

口pAcho que não

$\square$ pNão sabe

口pNão opinou

6. Quando o Sr. (a) não está se sentindo mal, o sr.(a) deixa de tomar os remédios ou continua?

$\square$ pDeixa de tomar os remédios

口pToma menos comprimidos dos remédios

口pContinua tomando do mesmo jeito

口poutros

口pNão sabe

口pNão opinou 
7. Em casa, onde o Sr. (a) costuma guardar os seus remédios?

口pEm uma caixinha, sacola, cestinha, gaveta ou outro local específico

DpEm uma gaveta especifica

$\square$ pNa mesma bolsinha ou recipiente que leva pra a rua

口pNão tem um lugar especifico para guardar

पpoutros

पpNão sabe

口pNão opinou

\section{Em casa, onde o sr. deixa os remédios?}

\section{$\square$ pNa caixa}

$\square$ pNa cartela $>$ fora da caixa

口pComprimidos separados no porta-comprimidos

口pComprimidos separados em algum outro lugar

पpoutros

पpNão sabe

पpNão opinou

口pNão opinou

9. Quando sai, o sr. (a) leva os remédios?

\section{口psempre}

$\square p S o ́$ quando vai passar a noite fora

DpNunca

DpOutros

पpNão sabe

口pNão opinou

9.1 (se leva os remédios)

Onde o Sr. (a) costuma levar o remédio?

DpDentro da caixa

पpCartelas dentro de uma bolsinha ou outro recipiente

口pCartelas na carteira

$\square \mathrm{pNa}(\mathrm{s})$ cartela(s)

पpSó os comprimidos que vai tomar em alguma vasilha/bolsinha

口pSó os comprimidos que vai tomar em um porta comprimidos

पpSó os comprimidos que vai tomar

पpoutros

पpNão sabe

पpNão opinou

10. Se eu tirar todas as cartelas dos seus remédios das caixas e colocar em cimade uma mesa uma do lado da outra, o Sr. (a) Sabe me dizer qual é qual?

पpsim

DpAguns

口pNão

पpNão sabe

口pNão opinou

10.1 (se se sim) O que tem de diferente na carttela que faz você saber qual é qual? 口pNome na cartela

口pCor da cartela ou outras cacacterísticas de impressão

口pPelo tamanho/forma da cartela

口pPela forma ou outras características do comprimido

DpOutros

口pNão sabe

口pNão opinou 
16. Para finalizar, vou dizer ao $\mathrm{Sr}$ (a) algumas coisas que alguns pacientes me disseram que acham difícil. Gostaria que o Sr. (a) me dissesse se acha, fácil, difícil, ou se depende.

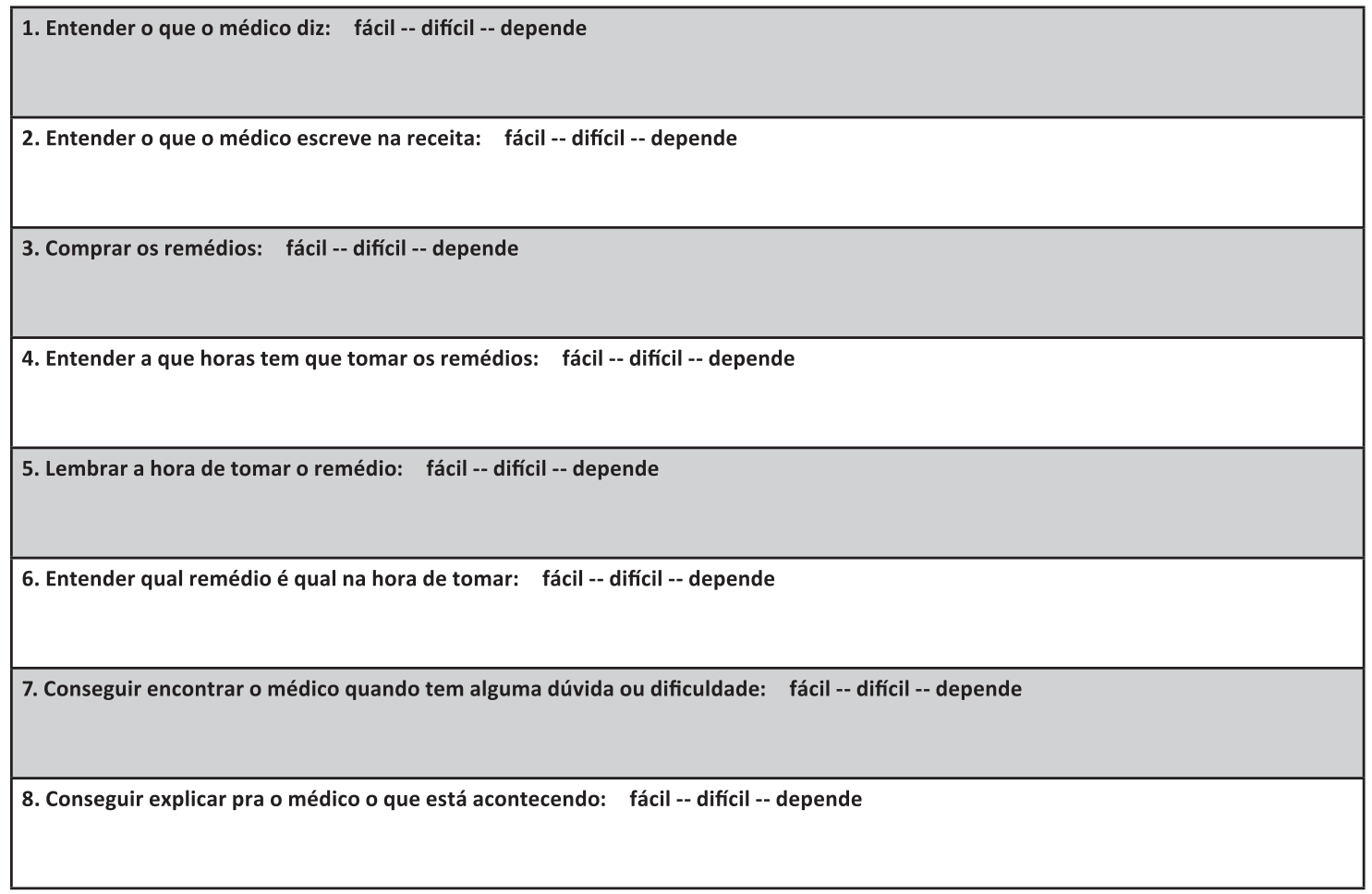

As perguntas que vou te fazer agora são um pouco diferentes.

Não são sobre os remédios que o Sr. (a) toma, mas como se fosse um remédio novo que um médico receitou.

17. Se esse outro remédio tivesse que ser tomado duas vezes ao dia, em que horário o sr. (a) tomaria?

18. E se esse outro remédio tivesse que ser tomado três vezes ao dia, em que horário o sr. (a) tomaria? 
19. E se esse outro remédio tivesse que ser tomado de 12 em 12 horas, , em que horário o sr. (a) tomaria?

20. E se esse outro remédio tivesse que ser tomadode 8 em 8 horas, em que horário o Sr. (a) tomaria?

Tem mais alguma coisa que o sr queira dizer?

Local da entrevista:

Data da entrevista 


\section{DADOS GERAIS DO ENTREVISTADO}

Ha quanto tempo o Sr. (a) tem que tomar remédios todos os dias?

[ ]phá menos de 1 ano

[ ]pde 1 a 5 anos

[ ]pmais de 5 anos

O Sr. segue receita que quantos médicos passam para você?

[ ]p1 médico

[ ]p2 médicos

[ ]p3 ou mais médicos

Qual é a idade do Sr. (a)?

[ ]p0 a 2 anos

[ ]p2 a 5 anos

[ ]p6 a 11 anos

[ ]p12 a 17 anos

[ ]p18 a 24 anos

[ ]p25 a 35 anos

[ ]p36 a 49 anos

[ ]p50 a 64 anos

[ ]p65 a 79 anos

[ ]p80 anos ou mais

Até que série o Sr. (a) estudou?

[ ]pnão frequentou escola

[ ]pensino fundamental__completo _ incompleto

[ ]pensino médio __completo __incompleto

[ ]pensino superior __completo _ incompleto

O sr. (a) poderia me dizer em que faixa de renda está os seus vencimentos?

[ ]pdependente de terceiros

[ ]paté $\mathrm{R} \$ 545,00$

[ ]pde $R \$ 546,00$ a $R \$ 1.635,00$

[ ]pde $R \$ R \$ 1.636,00$ a $R \$ 5450,00$

[ ]pmais que $\mathrm{R} \$ 5.451,00$

Muito obrigada. Sua entrevista foi muito importante pra o meu trabalho. 
Apêndice 3: termo de consentimento para entrevista focada 


\section{TERMO DE CONSENTIMENTO LIVRE E ESCLARECIDO}

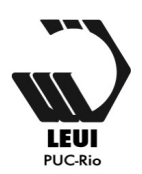

!

$\mathrm{O}(\mathrm{a}) \operatorname{Sr}(a)$ foi selecionado(a) e está sendo convidado(a) para participar da pesquisa intitulada: "A! Comunicação na Utilização de Medicamentos no tratamento de doenças crônicas: 0 campo de experiência do paciente" ${ }^{\prime}$, que tem como objetivos: conhecer melhor o cotidiano do uso de medicamentos por pessoas que tomam remédios diariamente. Este estudo utilizando como método a entrevista com pacientes que tomam medicação diariamente. Parte da metodologia para obtenção de dados nesta pesquisa consiste em realizar entrevistas com pacientes, cujas respostas serão indicadores da relevância do cumprimento do objetivo do estudo em questão.

Suas respostas serão tratadas de forma anonima e confidencial, isto é, em nenhum momento será divulgado o seu nome em qualquer fase do estudo. Quando for necessário exemplificar determinada situação, sua privacidade será assegurada uma vez que seu nome será substituído de forma aleatória. Os dados coletados serão utilizados apenas nesta pesquisa e os resultados divulgados em eventos e/ou revistas cientificas.

Sua participação é voluntária, isto é, a qualquer momento vocé pode recusar-se a responder qualquer pergunta ou desistir de participar e retirar seu consentimento. Sua recusa não trará nenhum prejuízo em sua relação com o pesquisador ou com a instituição que forneceu os seus dados, como também na que trabalha.

Sua participação nesta pesquisa consistirá em responder as perguntas a serem realizadas sob a forma de uma entrevista com um pequeno questionário no final. A entrevista será gravada para posterior transcrição.

$\operatorname{Sr}(a)$ não terá nenhum custo ou quaisquer compensações financeiras. Não haverá riscos de qualquer natureza relacionada a sua participação. $\mathrm{O}$ benefício relacionado à sua participação será de aumentar $\mathrm{O}$ conhecimento científico para a área de Ergonomia a respeito do uso de medicamentos administardos pelos pacientes.

O Sr(a) receberá uma cópia deste termo onde consta o celular/e-mail do pesquisador responsável, e email da professora orientadora da pesquisa, podendo tirar as suas dúvidas sobre o projeto e sua participação, agora ou a qualquer momento. Desde já agradecemos!

Estou ciente e de acordo com os termos de realização desta pesquisa, e autorizo por meio deste a publicação dos resultados obtidos no presente estudo, sendo a minha identidade mantida em sigilo. Concordo em participar voluntariamente desse estudo sendo que poderei retirar o meu consentimento a qualquer momento, antes ou durante o mesmo, sem penalidades ou prejuízos.

Rio de Janeiro, de de 2011.

Assinatura do participante voluntário

Vera Lima, pesquisadora
[21] 9457-2943

veradirect@yahoo.com.b

Prof. Dra. Anamaria de Moraes, orientadora moraergo@puc-rio.br

PUC - Rio Departamento de Artes e Design

LEUI - Laboratório de Ergonomia e Usabilidade de Interfaces em Sistemas Humano- Tecnologia Rua Marquês de São Vicente, 225 - sala 715F - Gávea, Rio de Janeiro - Brasil CEP: 22453-900 Tel: (21) 3527-1590, ramal 325

! 


\section{Anexos}

Anexo 1: resolução $n^{\circ} 196$ de 10 de outubro de 1996

\section{CONSELHO NACIONAL DE SAÚDE RESOLUÇÃO Nº 196 DE 10 DE OUTUBRO DE 1996}

O Plenário do Conselho Nacional de Saúde em sua Quinquagésima Nona Reunião Ordinária, realizada nos dias 09 e 10 de outubro de 1996, no uso de suas competências regimentais e atribuições conferidas pela Lei $n^{\circ} 8.080$, de 19 de setembro de 1990 , e pela Lei $n^{\circ} 8.142$, de 28 de dezembro de 1990, RESOLVE:

Aprovar as seguintes diretrizes e normas regulamentadoras de pesquisas envolvendo seres humanos:

\section{I - PREÂMBULO}

A presente Resolução fundamenta-se nos principais documentos internacionais que emanaram declarações e diretrizes sobre pesquisas que envolvem seres humanos: o Código de Nuremberg (1947), a Declaração dos Direitos do Homem (1948), a Declaração de Helsinque (1964 e suas versões posteriores de 1975, 1983 e 1989), o Acordo Internacional sobre Direitos Civis e Políticos (ONU, 1966, aprovado pelo Congresso Nacional Brasileiro em 1992), as Propostas de Diretrizes Éticas Internacionais para Pesquisas Biomédicas Envolvendo Seres Humanos (CIOMS/OMS 1982 e 1993) e as Diretrizes Internacionais para Revisão Ética de Estudos Epidemiológicos (CIOMS, 1991). Cumpre as disposições da Constituição da República Federativa do Brasil de 1988 e da legislação brasileira correlata: Código de Direitos do Consumidor, Código Civil e Código Penal, Estatuto da Criança e do Adolescente, Lei Orgânica da Saúde 8.080, de 19/09/90 (dispõe sobre as condições de atenção à saúde, a organização e o funcionamento dos serviços correspondentes), Lei 8.142, de 28/12/90 (participação da comunidade na gestão do Sistema Único de Saúde), Decreto 99.438, de 07/08/90 (organização e atribuições do Conselho Nacional de Saúde), Decreto 98.830, de 15/01/90 (coleta por estrangeiros de dados e materiais científicos no Brasil), Lei 8.489, de 18/11/92, e Decreto 879, de 22/07/93 (dispõem sobre retirada de tecidos, órgãos e outras partes do corpo humano com fins humanitários e científicos), Lei 8.501, de 30/11/92 (utilização de cadáver), Lei 8.974, de 05/01/95 (uso das técnicas de engenharia genética e liberação no meio ambiente de organismos geneticamente modificados), Lei 9.279, de 14/05/96 (regula direitos e obrigações relativos à propriedade industrial), e outras.

Esta Resolução incorpora, sob a ótica do indivíduo e das coletividades, os quatro referenciais básicos da bioética: autonomia, não maleficência, beneficência e justiça, entre outros, e visa assegurar os direitos e deveres que dizem respeito à comunidade científica, aos sujeitos da pesquisa e ao Estado. 
O caráter contextual das considerações aqui desenvolvidas implica em revisões periódicas desta Resolução, conforme necessidades nas áreas tecnocientífica e ética.

Ressalta-se, ainda, que cada área temática de investigação e cada modalidade de pesquisa, além de respeitar os princípios emanados deste texto, deve cumprir com as exigências setoriais e regulamentações específicas.

\section{II - TERMOS E DEFINIÇÕES}

A presente Resolução, adota no seu âmbito as seguintes definições:

II.1 - Pesquisa - classe de atividades cujo objetivo é desenvolver ou contribuir para o conhecimento generalizável. O conhecimento generalizável consiste em teorias, relações ou princípios ou no acúmulo de informações sobre as quais estão baseados, que possam ser corroborados por métodos científicos aceitos de observação e inferência.

II.2 - Pesquisa envolvendo seres humanos - pesquisa que, individual ou coletivamente, envolva o ser humano, de forma direta ou indireta, em sua totalidade ou partes dele, incluindo o manejo de informações ou materiais.

II.3 - Protocolo de Pesquisa - Documento contemplando a descrição da pesquisa em seus aspectos fundamentais, informações relativas ao sujeito da pesquisa, à qualificação dos pesquisadores e à todas as instâncias responsáveis.

II.4 - Pesquisador responsável - pessoa responsável pela coordenação e realização da pesquisa e pela integridade e bem-estar dos sujeitos da pesquisa.

II.5 - Instituição de pesquisa - organização, pública ou privada, legitimamente constituída e habilitada na qual são realizadas investigações científicas.

II.6 - Promotor - indivíduo ou instituição, responsável pela promoção da pesquisa.

II.7 - Patrocinador - pessoa física ou jurídica que apoia financeiramente a pesquisa.

II.8 - Risco da pesquisa - possibilidade de danos à dimensão física, psíquica, moral, intelectual, social, cultural ou espiritual do ser humano, em qualquer fase de uma pesquisa e dela decorrente.

II.9 - Dano associado ou decorrente da pesquisa - agravo imediato ou tardio, ao indivíduo ou à coletividade, com nexo causal comprovado, direto ou indireto, decorrente do estudo científico.

II.10 - Sujeito da pesquisa - é o(a) participante pesquisado(a), individual ou coletivamente, de caráter voluntário, vedada qualquer forma de remuneração.

II.11 - Consentimento livre e esclarecido - anuência do sujeito da pesquisa e/ou de seu representante legal, livre de vícios (simulação, fraude ou erro), dependência, subordinação ou intimidação, após explicação completa e pormenorizada sobre a natureza da pesquisa, seus objetivos, métodos, benefícios previstos, potenciais riscos e o incômodo que esta possa acarretar, formulada em um termo de consentimento, autorizando sua participação voluntária na pesquisa.

II.12 - Indenização - cobertura material, em reparação a dano imediato ou tardio, causado pela pesquisa ao ser humano a ela submetida.

II.13 - Ressarcimento - cobertura, em compensação, exclusiva de despesas decorrentes da participação do sujeito na pesquisa.

II.14 - Comitês de Ética em Pesquisa-CEP - colegiados interdisciplinares e independentes, com "munus público", de caráter consultivo, deliberativo e educativo, criados para defender os interesses dos sujeitos da pesquisa em sua integridade e dignidade e para contribuir no desenvolvimento da pesquisa dentro de padrões éticos. 
II.15 - Vulnerabilidade - refere-se a estado de pessoas ou grupos que, por quaisquer razões ou motivos, tenham a sua capacidade de autodeterminação reduzida, sobretudo no que se refere ao consentimento livre e esclarecido.

II.16 - Incapacidade - Refere-se ao possível sujeito da pesquisa que não tenha capacidade civil para dar o seu consentimento livre e esclarecido, devendo ser assistido ou representado, de acordo com a legislação brasileira vigente.

\section{III - ASPECTOS ÉTICOS DA PESQUISA ENVOLVENDO SERES HUMANOS}

As pesquisas envolvendo seres humanos devem atender às exigências éticas e científicas fundamentais.

III.1 - A eticidade da pesquisa implica em:

a) consentimento livre e esclarecido dos indivíduos-alvo e a proteção a grupos vulneráveis e aos legalmente incapazes (autonomia). Neste sentido, a pesquisa envolvendo seres humanos deverá sempre tratá-los em sua dignidade, respeitá-los em sua autonomia e defendê-los em sua vulnerabilidade;

b) ponderação entre riscos e benefícios, tanto atuais como potenciais, individuais ou coletivos (beneficência), comprometendo-se com o máximo de benefícios e o mínimo de danos e riscos;

c) garantia de que danos previsíveis serão evitados (não maleficência);

d) relevância social da pesquisa com vantagens significativas para os sujeitos da pesquisa e minimização do ônus para os sujeitos vulneráveis, o que garante a igual consideração dos interesses envolvidos, não perdendo o sentido de sua destinação sócio-humanitária (justiça $e$ eqüidade).

III.2- Todo procedimento de qualquer natureza envolvendo o ser humano, cuja aceitação não esteja ainda consagrada na literatura científica, será considerado como pesquisa e, portanto, deverá obedecer às diretrizes da presente Resolução. Os procedimentos referidos incluem entre outros, os de natureza instrumental, ambiental, nutricional, educacional, sociológica, econômica, física, psíquica ou biológica, sejam eles farmacológicos, clínicos ou cirúrgicos e de finalidade preventiva, diagnóstica ou terapêutica.

III.3 - A pesquisa em qualquer área do conhecimento, envolvendo seres humanos deverá observar as seguintes exigências:

a) ser adequada aos princípios científicos que a justifiquem e com possibilidades concretas de responder a incertezas;

b) estar fundamentada na experimentação prévia realizada em laboratórios, animais ou em outros fatos científicos;

c) ser realizada somente quando o conhecimento que se pretende obter não possa ser obtido por outro meio;

d) prevalecer sempre as probabilidades dos benefícios esperados sobre os riscos previsíveis;

e) obedecer a metodologia adequada. Se houver necessidade de distribuição aleatória dos sujeitos da pesquisa em grupos experimentais e de controle, assegurar que, a priori, não seja possível estabelecer as vantagens de um procedimento sobre outro através de revisão de literatura, métodos observacionais ou métodos que não envolvam seres humanos;

f) ter plenamente justificada, quando for o caso, a utilização de placebo, em termos de não maleficência e de necessidade metodológica;

g) contar com o consentimento livre e esclarecido do sujeito da pesquisa e/ou seu representante legal;

h) contar com os recursos humanos e materiais necessários que garantam o bem-estar do sujeito da pesquisa, devendo ainda haver adequação entre a competência do pesquisador e o projeto proposto; 
i) prever procedimentos que assegurem a confidencialidade e a privacidade, a proteção da imagem e a não estigmatização, garantindo a não utilização das informações em prejuízo das pessoas e/ou das comunidades, inclusive em termos de auto-estima, de prestígio e/ou econômico - financeiro;

j) ser desenvolvida preferencialmente em indivíduos com autonomia plena. Indivíduos ou grupos vulneráveis não devem ser sujeitos de pesquisa quando a informação desejada possa ser obtida através de sujeitos com plena autonomia, a menos que a investigação possa trazer benefícios diretos aos vulneráveis. Nestes casos, o direito dos indivíduos ou grupos que queiram participar da pesquisa deve ser assegurado, desde que seja garantida a proteção à sua vulnerabilidade e incapacidade legalmente definida;

I) respeitar sempre os valores culturais, sociais, morais, religiosos e éticos, bem como os hábitos e costumes quando as pesquisas envolverem comunidades;

m) garantir que as pesquisas em comunidades, sempre que possível, traduzir-se-ão em benefícios cujos efeitos continuem a se fazer sentir após sua conclusão. $O$ projeto deve analisar as necessidades de cada um dos membros da comunidade e analisar as diferenças presentes entre eles, explicitando como será assegurado o respeito às mesmas;

n) garantir o retorno dos benefícios obtidos através das pesquisas para as pessoas e as comunidades onde as mesmas forem realizadas. Quando, no interesse da comunidade, houver benefício real em incentivar ou estimular mudanças de costumes ou comportamentos, o protocolo de pesquisa deve incluir, sempre que possível, disposições para comunicar tal benefício às pessoas e/ou comunidades;

o) comunicar às autoridades sanitárias os resultados da pesquisa, sempre que os mesmos puderem contribuir para a melhoria das condições de saúde da coletividade, preservando, porém, a imagem e assegurando que os sujeitos da pesquisa não sejam estigmatizados ou percam a auto-estima;

p) assegurar aos sujeitos da pesquisa os benefícios resultantes do projeto, seja em termos de retorno social, acesso aos procedimentos, produtos ou agentes da pesquisa;

q)assegurar aos sujeitos da pesquisa as condições de acompanhamento, tratamento ou de orientação, conforme o caso, nas pesquisas de rastreamento; demonstrar a preponderância de benefícios sobre riscos e custos;

r) assegurar a inexistência de conflito de interesses entre o pesquisador e os sujeitos da pesquisa ou patrocinador do projeto;

s) comprovar, nas pesquisas conduzidas do exterior ou com cooperação estrangeira, os compromissos e as vantagens, para os sujeitos das pesquisas e para o Brasil, decorrentes de sua realização. Nestes casos deve ser identificado o pesquisador e a instituição nacionais coresponsáveis pela pesquisa. O protocolo deverá observar as exigências da Declaração de Helsinque e incluir documento de aprovação, no país de origem, entre os apresentados para avaliação do Comitê de Ética em Pesquisa da instituição brasileira, que exigirá o cumprimento de seus próprios referenciais éticos. Os estudos patrocinados do exterior também devem responder às necessidades de treinamento de pessoal no Brasil, para que o país possa desenvolver projetos similares de forma independente;

t) utilizar o material biológico e os dados obtidos na pesquisa exclusivamente para a finalidade prevista no seu protocolo;

u) levar em conta, nas pesquisas realizadas em mulheres em idade fértil ou em mulheres grávidas, a avaliação de riscos e benefícios e as eventuais interferências sobre a fertilidade, a gravidez, o embrião ou o feto, o trabalho de parto, o puerpério, a lactação e o recém-nascido; 
v) considerar que as pesquisas em mulheres grávidas devem, ser precedidas de pesquisas em mulheres fora do período gestacional, exceto quando a gravidez for o objetivo fundamental da pesquisa;

x) propiciar, nos estudos multicêntricos, a participação dos pesquisadores que desenvolverão a pesquisa na elaboração do delineamento geral do projeto; $\mathrm{e}$

z) descontinuar o estudo somente após análise das razões da descontinuidade pelo CEP que a aprovou.

\section{IV - CONSENTIMENTO LIVRE E ESCLARECIDO}

O respeito devido à dignidade humana exige que toda pesquisa se processe após consentimento livre e esclarecido dos sujeitos, indivíduos ou grupos que por si e/ou por seus representantes legais manifestem a sua anuência à participação na pesquisa.

IV.1 - Exige-se que o esclarecimento dos sujeitos se faça em linguagem acessível e que inclua necessariamente os seguintes aspectos:

a) a justificativa, os objetivos e os procedimentos que serão utilizados na pesquisa;

b) os desconfortos e riscos possíveis e os benefícios esperados;

c) os métodos alternativos existentes;

d) a forma de acompanhamento e assistência, assim como seus responsáveis;

e) a garantia de esclarecimentos, antes e durante o curso da pesquisa, sobre a metodologia, informando a possibilidade de inclusão em grupo controle ou placebo;

f) a liberdade do sujeito se recusar a participar ou retirar seu consentimento, em qualquer fase da pesquisa, sem penalização alguma e sem prejuízo ao seu cuidado;

g) a garantia do sigilo que assegure a privacidade dos sujeitos quanto aos dados confidenciais envolvidos na pesquisa;

h) as formas de ressarcimento das despesas decorrentes da participação na pesquisa; e

i) as formas de indenização diante de eventuais danos decorrentes da pesquisa.

IV.2 - O termo de consentimento livre e esclarecido obedecerá aos seguintes requisitos:

a) ser elaborado pelo pesquisador responsável, expressando o cumprimento de cada uma das exigências acima;

b) ser aprovado pelo Comitê de Ética em Pesquisa que referenda a investigação;

c) ser assinado ou identificado por impressão dactiloscópica, por todos e cada um dos sujeitos da pesquisa ou por seus representantes legais; e

d) ser elaborado em duas vias, sendo uma retida pelo sujeito da pesquisa ou por seu representante legal e uma arquivada pelo pesquisador.

IV.3 - Nos casos em que haja qualquer restrição à liberdade ou ao esclarecimento necessários para o adequado consentimento, deve-se ainda observar:

a) em pesquisas envolvendo crianças e adolescentes, portadores de perturbação ou doença mental e sujeitos em situação de substancial diminuição em suas capacidades de consentimento, deverá haver justificação clara da escolha dos sujeitos da pesquisa, especificada no protocolo, aprovada pelo Comitê de Ética em Pesquisa, e cumprir as exigências do consentimento livre e esclarecido, através dos representantes legais dos referidos sujeitos, sem suspensão do direito de informação do indivíduo, no limite de sua capacidade;

b) a liberdade do consentimento deverá ser particularmente garantida para aqueles sujeitos que, embora adultos e capazes, estejam expostos a condicionamentos específicos ou à influência de autoridade, especialmente estudantes, militares, empregados, presidiários, internos em centros de readaptação, casas-abrigo, asilos, associações religiosas e semelhantes, assegurando-lhes a inteira liberdade de participar ou não da pesquisa, sem quaisquer represálias; 
c) nos casos em que seja impossível registrar o consentimento livre e esclarecido, tal fato deve ser devidamente documentado, com explicação das causas da impossibilidade, e parecer do Comitê de Ética em Pesquisa;

d) as pesquisas em pessoas com o diagnóstico de morte encefálica só podem ser realizadas desde que estejam preenchidas as seguintes condições:

- documento comprobatório da morte encefálica (atestado de óbito);

- consentimento explícito dos familiares e/ou do responsável legal, ou manifestação prévia da vontade da pessoa;

- respeito total à dignidade do ser humano sem mutilação ou violação do corpo;

- sem ônus econômico financeiro adicional à família;

- sem prejuízo para outros pacientes aguardando internação ou tratamento;

- possibilidade de obter conhecimento científico relevante, novo e que não possa ser obtido de outra maneira;

e) em comunidades culturalmente diferenciadas, inclusive indígenas, deve-se contar com a anuência antecipada da comunidade através dos seus próprios líderes, não se dispensando, porém, esforços no sentido de obtenção do consentimento individual;

f) quando o mérito da pesquisa depender de alguma restrição de informações aos sujeitos, tal fato deve ser devidamente explicitado e justificado pelo pesquisador e submetido ao Comitê de Ética em Pesquisa. Os dados obtidos a partir dos sujeitos da pesquisa não poderão ser usados para outros fins que os não previstos no protocolo e/ou no consentimento.

\section{V - RISCOS E BENEFÍcIOS}

Considera-se que toda pesquisa envolvendo seres humanos envolve risco. $\mathrm{O}$ dano eventual poderá ser imediato ou tardio, comprometendo o indivíduo ou a coletividade.

V.1 - Não obstante os riscos potenciais, as pesquisas envolvendo seres humanos serão admissíveis quando:

a) oferecerem elevada possibilidade de gerar conhecimento para entender, prevenir ou aliviar um problema que afete o bem-estar dos sujeitos da pesquisa e de outros indivíduos;

b) o risco se justifique pela importância do benefício esperado;

c) o benefício seja maior, ou no mínimo igual, a outras alternativas já estabelecidas para a prevenção, o diagnóstico e o tratamento.

V.2 - As pesquisas sem benefício direto ao indivíduo, devem prever condições de serem bem suportadas pelos sujeitos da pesquisa, considerando sua situação física, psicológica, social e educacional.

V.3 - O pesquisador responsável é obrigado a suspender a pesquisa imediatamente ao perceber algum risco ou dano à saúde do sujeito participante da pesquisa, conseqüente à mesma, não previsto no termo de consentimento. Do mesmo modo, tão logo constatada a superioridade de um método em estudo sobre outro, o projeto deverá ser suspenso, oferecendo-se a todos os sujeitos os benefícios do melhor regime.

V.4 - O Comitê de Ética em Pesquisa da instituição deverá ser informado de todos os efeitos adversos ou fatos relevantes que alterem o curso normal do estudo.

V.5 - O pesquisador, o patrocinador e a instituição devem assumir a responsabilidade de dar assistência integral às complicações e danos decorrentes dos riscos previstos.

V.6 - Os sujeitos da pesquisa que vierem a sofrer qualquer tipo de dano previsto ou não no termo de consentimento e resultante de sua participação, além do direito à assistência integral, têm direito à indenização. 
V.7 - Jamais poderá ser exigido do sujeito da pesquisa, sob qualquer argumento, renúncia ao direito à indenização por dano. O formulário do consentimento livre e esclarecido não deve conter nenhuma ressalva que afaste essa responsabilidade ou que implique ao sujeito da pesquisa abrir mão de seus direitos legais, incluindo o direito de procurar obter indenização por danos eventuais.

\section{VI - PROTOCOLO DE PESQUISA}

O protocolo a ser submetido à revisão ética somente poderá ser apreciado se estiver instruído com os seguintes documentos, em português:

VI.1 - folha de rosto: título do projeto, nome, número da carteira de identidade, CPF, telefone e endereço para correspondência do pesquisador responsável e do patrocinador, nome e assinaturas dos dirigentes da instituição e/ou organização;

VI.2 - descrição da pesquisa, compreendendo os seguintes itens:

a) descrição dos propósitos e das hipóteses a serem testadas;

b) antecedentes científicos e dados que justifiquem a pesquisa. Se o propósito for testar um novo produto ou dispositivo para a saúde, de procedência estrangeira ou não, deverá ser indicada a situação atual de registro junto a agências regulatórias do país de origem;

c) descrição detalhada e ordenada do projeto de pesquisa (material e métodos, casuística, resultados esperados e bibliografia);

d) análise crítica de riscos e benefícios;

e) duração total da pesquisa, a partir da aprovação;

f) explicitaçao das responsabilidades do pesquisador, da instituição, do promotor e do patrocinador;

g) explicitação de critérios para suspender ou encerrar a pesquisa;

h) local da pesquisa: detalhar as instalações dos serviços, centros, comunidades e instituições nas quais se processarão as várias etapas da pesquisa;

i) demonstrativo da existência de infra-estrutura necessária ao desenvolvimento da pesquisa e para atender eventuais problemas dela resultantes, com a concordância documentada da instituição;

j) orçamento financeiro detalhado da pesquisa: recursos, fontes e destinação, bem como a forma e o valor da remuneração do pesquisador;

I) explicitação de acordo preexistente quanto à propriedade das informações geradas, demonstrando a inexistência de qualquer cláusula restritiva quanto à divulgação pública dos resultados, a menos que se trate de caso de obtenção de patenteamento; neste caso, os resultados devem se tornar públicos, tão logo se encerre a etapa de patenteamento;

m) declaração de que os resultados da pesquisa serão tornados públicos, sejam eles favoráveis ou não; e

n) declaração sobre o uso e destinação do material e/ou dados coletados.

VI.3 - informações relativas ao sujeito da pesquisa:

a) descrever as características da população a estudar: tamanho, faixa etária, sexo, cor (classificação do IBGE), estado geral de saúde, classes e grupos sociais, etc. Expor as razões para a utilização de grupos vulneráveis;

b) descrever os métodos que afetem diretamente os sujeitos da pesquisa;

c) identificar as fontes de material de pesquisa, tais como espécimens, registros e dados a serem obtidos de seres humanos. Indicar se esse material será obtido especificamente para os propósitos da pesquisa ou se será usado para outros fins;

d) descrever os planos para o recrutamento de indivíduos e os procedimentos a serem seguidos. Fornecer critérios de inclusão e exclusão; 
e) apresentar o formulário ou termo de consentimento, específico para a pesquisa, para a apreciação do Comitê de Ética em Pesquisa, incluindo informações sobre as circunstâncias sob as quais o consentimento será obtido, quem irá tratar de obtê-lo e a natureza da informação a ser fornecida aos sujeitos da pesquisa;

f) descrever qualquer risco, avaliando sua possibilidade e gravidade;

g) descrever as medidas para proteção ou minimização de qualquer risco eventual. Quando apropriado, descrever as medidas para assegurar os necessários cuidados à saúde, no caso de danos aos indivíduos. Descrever também os procedimentos para monitoramento da coleta de dados para prover a segurança dos indivíduos, incluindo as medidas de proteção à confidencialidade; $\mathrm{e}$

h) apresentar previsão de ressarcimento de gastos aos sujeitos da pesquisa. A importância referente não poderá ser de tal monta que possa interferir na autonomia da decisão do indivíduo ou responsável de participar ou não da pesquisa.

VI.4 - qualificação dos pesquisadores: "Curriculum vitae" do pesquisador responsável e dos demais participantes.

VI.5 - termo de compromisso do pesquisador responsável e da instituição de cumprir os termos desta Resolução.

\section{VII - COMITÊ DE ÉTICA EM PESQUISA-CEP}

Toda pesquisa envolvendo seres humanos deverá ser submetida à apreciação de um Comitê de Ética em Pesquisa.

VII.1 - As instituições nas quais se realizem pesquisas envolvendo seres humanos deverão constituir um ou mais de um Comitê de Ética em Pesquisa- CEP, conforme suas necessidades.

VII.2 - Na impossibilidade de se constituir CEP, a instituição ou o pesquisador responsável deverá submeter o projeto à apreciação do CEP de outra instituição, preferencialmente dentre os indicados pela Comissão Nacional de Ética em Pesquisa (CONEP/MS).

VII.3 - Organização - A organização e criação do CEP será da competência da instituição, respeitadas as normas desta Resolução, assim como o provimento de condições adequadas para o seu funcionamento.

VII.4 - Composição - O CEP deverá ser constituído por colegiado com número não inferior a 7 (sete) membros. Sua constituição deverá incluir a participação de profissionais da área de saúde, das ciências exatas, sociais e humanas, incluindo, por exemplo, juristas, teólogos, sociólogos, filósofos, bioeticistas e, pelo menos, um membro da sociedade representando os usuários da instituição. Poderá variar na sua composição, dependendo das especificidades da instituição e das linhas de pesquisa a serem analisadas.

VII.5 - Terá sempre caráter multi e transdisciplinar, não devendo haver mais que metade de seus membros pertencentes à mesma categoria profissional, participando pessoas dos dois sexos. Poderá ainda contar com consultores "ad hoc", pessoas pertencentes ou não à instituição, com a finalidade de fornecer subsídios técnicos.

VII.6 - No caso de pesquisas em grupos vulneráveis, comunidades e coletividades, deverá ser convidado um representante, como membro "ad hoc" do CEP, para participar da análise do projeto específico.

VII.7 - Nas pesquisas em população indígena deverá participar um consultor familiarizado com os costumes e tradições da comunidade.

VII.8 - Os membros do CEP deverão se isentar de tomada de decisão, quando diretamente envolvidos na pesquisa em análise. 
VII.9 - Mandato e escolha dos membros - A composição de cada CEP deverá ser definida a critério da instituição, sendo pelo menos metade dos membros com experiência em pesquisa, eleitos pelos seus pares. A escolha da coordenação de cada Comitê deverá ser feita pelos membros que compõem o colegiado, durante a primeira reunião de trabalho. Será de três anos a duração do mandato, sendo permitida recondução.

VII.10 - Remuneração - Os membros do CEP não poderão ser remunerados no desempenho desta tarefa, sendo recomendável, porém, que sejam dispensados nos horários de trabalho do Comitê das outras obrigações nas instituições às quais prestam serviço, podendo receber ressarcimento de despesas efetuadas com transporte, hospedagem e alimentação.

VII.11 - Arquivo - O CEP deverá manter em arquivo o projeto, o protocolo e os relatórios correspondentes, por 5 (cinco) anos após o encerramento do estudo.

VII.12 - Liberdade de trabalho - Os membros dos CEPs deverão ter total independência na tomada das decisões no exercício das suas funções, mantendo sob caráter confidencial as informações recebidas. Deste modo, não podem sofrer qualquer tipo de pressão por parte de superiores hierárquicos ou pelos interessados em determinada pesquisa, devem isentar-se de envolvimento financeiro e não devem estar submetidos a conflito de interesse.

\section{VII.13 - Atribuições do CEP:}

a) revisar todos os protocolos de pesquisa envolvendo seres humanos, inclusive os multicêntricos, cabendo-lhe a responsabilidade primária pelas decisões sobre a ética da pesquisa a ser desenvolvida na instituição, de modo a garantir e resguardar a integridade e os direitos dos voluntários participantes nas referidas pesquisas;

b) emitir parecer consubstanciado por escrito, no prazo máximo de 30 (trinta) dias, identificando com clareza o ensaio, documentos estudados e data de revisão. A revisão de cada protocolo culminará com seu enquadramento em uma das seguintes categorias:

- aprovado;

- com pendência: quando o Comitê considera o protocolo como aceitável, porém identifica determinados problemas no protocolo, no formulário do consentimento ou em ambos, e recomenda uma revisão específica ou solicita uma modificação ou informação relevante, que deverá ser atendida em 60 (sessenta) dias pelos pesquisadores;

- retirado: quando, transcorrido o prazo, o protocolo permanece pendente;

- não aprovado; e

- aprovado e encaminhado, com o devido parecer, para apreciação pela Comissão Nacional de Ética em Pesquisa -CONEP/MS, nos casos previstos no capítulo VIII, item 4.c.

c) manter a guarda confidencial de todos os dados obtidos na execução de sua tarefa e arquivamento do protocolo completo, que ficará à disposição das autoridades sanitárias;

d) acompanhar o desenvolvimento dos projetos através de relatórios anuais dos pesquisadores;

e) desempenhar papel consultivo e educativo, fomentando a reflexão em torno da ética na ciência;

f) receber dos sujeitos da pesquisa ou de qualquer outra parte denúncias de abusos ou notificação sobre fatos adversos que possam alterar o curso normal do estudo, decidindo pela continuidade, modificação ou suspensão da pesquisa, devendo, se necessário, adequar o termo de consentimento. Considera-se como anti-ética a pesquisa descontinuada sem justificativa aceita pelo CEP que a aprovou;

g) requerer instauração de sindicância à direção da instituição em caso de denúncias de irregularidades de natureza ética nas pesquisas e, em havendo comprovação, comunicar à Comissão Nacional de Ética em Pesquisa-CONEP/MS e, no que couber, a outras instâncias; e h) manter comunicação regular e permanente com a CONEP/MS. 


\section{VII.14 - Atuação do CEP:}

a) A revisão ética de toda e qualquer proposta de pesquisa envolvendo seres humanos não poderá ser dissociada da sua análise científica. Pesquisa que não se faça acompanhar do respectivo protocolo não deve ser analisada pelo Comitê.

b) Cada CEP deverá elaborar suas normas de funcionamento, contendo metodologia de trabalho, a exemplo de: elaboração das atas; planejamento anual de suas atividades; periodicidade de reuniões; número mínimo de presentes para início das reuniões; prazos para emissão de pareceres; critérios para solicitação de consultas de experts na área em que se desejam informações técnicas; modelo de tomada de decisão, etc.

\section{VIII - COMISSÃO NACIONAL DE ÉTICA EM PESQUISA (CONEP/MS)}

A Comissão Nacional de Ética em Pesquisa - CONEP/MS é uma instância colegiada, de natureza consultiva, deliberativa, normativa, educativa, independente, vinculada ao Conselho Nacional de Saúde.

O Ministério da Saúde adotará as medidas necessárias para o funcionamento pleno da Comissão e de sua Secretaria Executiva.

VIII.1 - Composição: A CONEP terá composição multi e transdiciplinar, com pessoas de ambos os sexos e deverá ser composta por 13 (treze) membros titulares e seus respectivos suplentes, sendo 05 (cinco) deles personalidades destacadas no campo da ética na pesquisa e na saúde e 08 (oito) personalidades com destacada atuação nos campos teológico, jurídico e outros, assegurando-se que pelo menos um seja da área de gestão da saúde. Os membros serão selecionados, a partir de listas indicativas elaboradas pelas instituições que possuem CEP registrados na CONEP, sendo que 07 (sete) serão escolhidos pelo Conselho Nacional de Saúde e 06 (seis) serão definidos por sorteio. Poderá contar também com consultores e membros "ad hoc", assegurada a representação dos usuários.

VIII.2 - Cada CEP poderá indicar duas personalidades.

VIII.3 - O mandato dos membros da CONEP será de quatro anos com renovação alternada a cada dois anos, de sete ou seis de seus membros.

VIII.4 - Atribuições da CONEP - Compete à CONEP o exame dos aspectos éticos da pesquisa envolvendo seres humanos, bem como a adequação e atualização das normas atinentes. A CONEP consultará a sociedade sempre que julgar necessário, cabendo-Ihe, entre outras, as seguintes atribuições:

a) estimular a criação de CEPs institucionais e de outras instâncias;

b) registrar os CEPs institucionais e de outras instâncias;

c) aprovar, no prazo de 60 dias, e acompanhar os protocolos de pesquisa em áreas temáticas especiais tais como:

1- genética humana;

2- reprodução humana;

3- farmácos, medicamentos, vacinas e testes diagnósticos novos (fases I, II e III) ou não registrados no país (ainda que fase IV), ou quando a pesquisa for referente a seu uso com modalidades, indicações, doses ou vias de administração diferentes daquelas estabelecidas, incluindo seu emprego em combinações;

4- equipamentos, insumos e dispositivos para a saúde novos, ou não registrados no país;

5- novos procedimentos ainda não consagrados na literatura;

6- populações indígenas;

7- projetos que envolvam aspectos de biossegurança;

8- pesquisas coordenadas do exterior ou com participação estrangeira e pesquisas que envolvam remessa de material biológico para o exterior; e 
9- projetos que, a critério do CEP, devidamente justificado, sejam julgados merecedores de análise pela CONEP;

d) prover normas específicas no campo da ética em pesquisa, inclusive nas áreas temáticas especiais, bem como recomendações para aplicação das mesmas;

e) funcionar como instância final de recursos, a partir de informações fornecidas sistematicamente, em caráter ex-ofício ou a partir de denúncias ou de solicitação de partes interessadas, devendo manifestar-se em um prazo não superior a 60 (sessenta) dias;

f) rever responsabilidades, proibir ou interromper pesquisas, definitiva ou temporariamente, podendo requisitar protocolos para revisão ética inclusive, os já aprovados pelo CEP;

g) constituir um sistema de informação e acompanhamento dos aspectos éticos das pesquisas envolvendo seres humanos em todo o território nacional, mantendo atualizados os bancos de dados;

h) informar e assessorar o MS, o CNS e outras instâncias do SUS, bem como do governo e da sociedade, sobre questões éticas relativas à pesquisa em seres humanos;

i) divulgar esta e outras normas relativas à ética em pesquisa envolvendo seres humanos;

j) a CONEP juntamente com outros setores do Ministério da Saúde, estabelecerá normas e critérios para o credenciamento de Centros de Pesquisa. Este credenciamento deverá ser proposto pelos setores do Ministério da Saúde, de acordo com suas necessidades, e aprovado pelo Conselho Nacional de Saúde; e

I) estabelecer suas próprias normas de funcionamento.

VIII.5 - A CONEP submeterá ao CNS para sua deliberação:

a) propostas de normas gerais a serem aplicadas às pesquisas envolvendo seres humanos, inclusive modificações desta norma;

b) plano de trabalho anual;

c) relatório anual de suas atividades, incluindo sumário dos CEP estabelecidos e dos projetos analisados.

\section{IX - OPERACIONALIZAÇÃO}

IX.1 - Todo e qualquer projeto de pesquisa envolvendo seres humanos deverá obedecer às recomendações desta Resolução e dos documentos endossados em seu preâmbulo. A responsabilidade do pesquisador é indelegável, indeclinável e compreende os aspectos éticos e leagis.

IX.2 - Ao pesquisador cabe:

a) apresentar o protocolo, devidamente instruido ao CEP, aguardando o pronunciamento deste, antes de iniciar a pesquisa;

b) desenvolver o projeto conforme delineado;

c) elaborar e apresentar os relatórios parciais e final;

d) apresentar dados solicitados pelo CEP, a qualquer momento;

e) manter em arquivo, sob sua guarda, por 5 anos, os dados da pesquisa, contendo fichas individuais e todos os demais documentos recomendados pelo CEP;

f) encaminhar os resultados para publicação, com os devidos créditos aos pesquisadores associados e ao pessoal técnico participante do projeto;

g) justificar, perante o CEP, interrupção do projeto ou a não publicação dos resultados.

IX.3 - O Comitê de Ética em Pesquisa institucional deverá estar registrado junto à CONEP/MS.

IX.4 - Uma vez aprovado o projeto, o CEP passa a ser co-responsável no que se refere aos aspectos éticos da pesquisa. 
IX.5 - Consideram-se autorizados para execução, os projetos aprovados pelo CEP, exceto os que se enquadrarem nas áreas temáticas especiais, os quais, após aprovação pelo CEP institucional deverão ser enviados à CONEP/MS, que dará o devido encaminhamento.

IX.6 - Pesquisas com novos medicamentos, vacinas, testes diagnósticos, equipamentos e dispositivos para a saúde deverão ser encaminhados do CEP à CONEP/MS e desta, após parecer, à Secretaria de Vigilância Sanitária.

IX.7 - As agências de fomento à pesquisa e o corpo editorial das revistas científicas deverão exigir documentação comprobatória de aprovação do projeto pelo CEP e/ou CONEP, quando for o caso.

IX.8 - Os CEP institucionais deverão encaminhar trimestralmente à CONEP/MS a relação dos projetos de pesquisa analisados, aprovados e concluídos, bem como dos projetos em andamento e, imediatamente, aqueles suspensos.

\section{$X$. DISPOSIÇÕES TRANSITÓRIAS}

X.1 - O Grupo Executivo de Trabalho-GET, constituido através da Resolução CNS 170/95, assumirá as atribuições da CONEP até a sua constituição, responsabilizando-se por:

a) tomar as medidas necessárias ao processo de criação da CONEP/MS;

b) estabelecer normas para registro dos CEP institucionais;

X.2 - O GET terá 180 dias para finalizar as suas tarefas.

X.3 - Os CEP das instituições devem proceder, no prazo de 90 (noventa) dias, ao levantamento e análise, se for o caso, dos projetos de pesquisa em seres humanos já em andamento, devendo encaminhar à CONEP/MS, a relação dos mesmos.

X4 - Fica revogada a Resolução 01/88.

\section{ADIB D. JATENE}

Presidente do Conselho Nacional de Saúde

Homologo a Resolução CNS n 196, de 10 de outubro de 1996, nos termos do Decreto de Delegação de Competência de 12 de novembro de 1991.

\section{ADIB D. JATENE}

Ministro de Estado da Saúde 
Anexo 2: Parecer favorável

da Comissão de Ética na pesquisa da Puc-Rio 


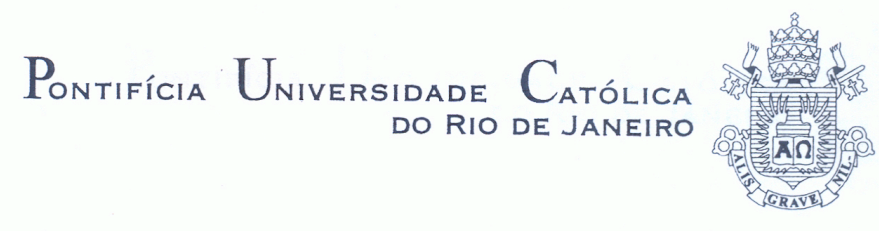

CI. VRAc. 01/2012

Rio de Janeiro, 04 de janeiro de 2012.

DE: $\quad$ Prof. José Ricardo Bergmann

Vice-Reitor para Assuntos Acadêmicos

PARA: Prof $\stackrel{a}{-}$. Ana Maria de Moraes

Departamento de Artes \& Design

Prezada Professora,

Conforme solicitado por V.Sa. encaminhei ao CEP para análise o projeto intitulado "Comunicação na utilização ade medicamentos no tratamento de doenças crônicas: o campo de experiência do paciente".

O Conselho de Ensino e Pesquisa em sua 438 a reunião realizada em 07/12/11, homologou o parecer favorável emitido pela Câmara de Ética, conforme anexo.

Atenciosamente,

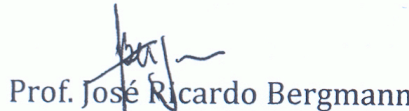

Vice-Reitor para Assuntos Acadêmicos 


\section{Pontifícia Universidade Católica} DO RIO DE JANEIRO

Título: Comunicação na utilização de medicamentos no tratamento de doenças crônicas: o campo de experiência do paciente

Parecer: Considerando os elementos expostos, somos de parecer favorável à aprovação do projeto quanto aos princípios e critérios estabelecidos pela Comissão de Ética na Pesquisa da PUC-Rio .

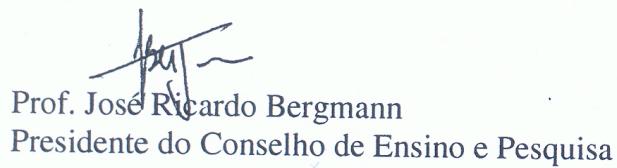




\section{Pontifícia Universidade C $_{\text {atólica }}$ \\ Pontifícia Universidade Católica do Rio de Janeiro \\ Câmara de Ética de Pesquisa da PUC-Rio \\ Parecer da Comissão de Ética na Pesquisa da PUC-Rio} DO RIO DE JANEIRO

A Comissão de Ética na Pesquisa da PUC-Rio foi constituída como uma Câmara específica do Conselho de Ensino e Pesquisa conforme decisão deste órgão colegiado com a atribuição de avaliar projetos de pesquisa do ponto de vista de suas implicações éticas.

\section{Parecer (2011-12)}

\section{Identificação:}

Título: Comunicação na utilização de medicamentos no tratamento de doenças crônicas: o campo de experiência do paciente.

\section{Autora:}

Vera Lopes de Abreu Lima ( Doutoranda do Departamento de Artes \& Design, PUC-Rio)

Profa. orientadora:

Anamaria de Moraes ( Departamento de Artes \& Design, PUC - Rio)

\section{Apresentação:}

Trata-se de um projeto de doutorado cujo objetivo principal e estudar a comunicação na prescrição , dispensação e no uso de medicamentos no tratamento de pacientes de doenças crônicas, na faixa etária de 25 anos ou mais, moradores da comunidade de Mangueira, Rio de Janeiro.

\section{Aspectos Éticos:}

O projeto observa os cuidados éticos imprescindíveis ‘a condução da pesquisa considerando a realidade da vulnerabilidade e competência `a autonomia de pessoas portadoras de doenças crônicas , residentes numa favela.

O Termo de Consentimento Livre e Esclarecido apresenta em linguagem clara as informações explicativas sobre os objetivos da pesquisa e os instrumentos de coleta de dados a serem usados. Além disso, assegura a confidencialidade e a privacidade dos sujeitos. Garante a possibilidade de retirada do participante de pesquisa em qualquer momento sem aplicação de constrangimentos ao mesmo. O projeto como um todo observa a valorização da pessoa humana, evidenciando o respeito aos princípios e valores estabelecidos no Marco Referencial, Estatuto e Regimento da PUC-Rio no que se refere `as responsabilidades de seu corpo docente e discente. 